Historic, archived document

Do not assume content reflects current scientific knowledge, policies, or practices. 

$-2 x+5$

\section{CATALOGUE Trom or}

10

(1) (2) (2)

(f)

WCMPUIS,

MLCMPIIIS,
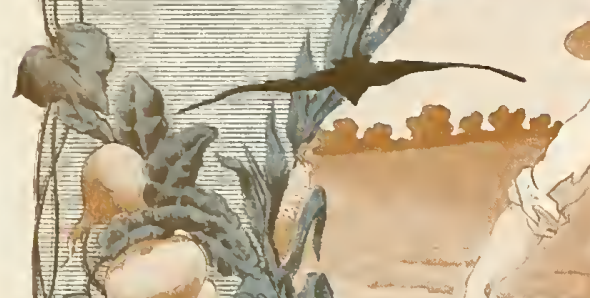

(3)

C. 10 en $=1$

$T_{-1}=1$

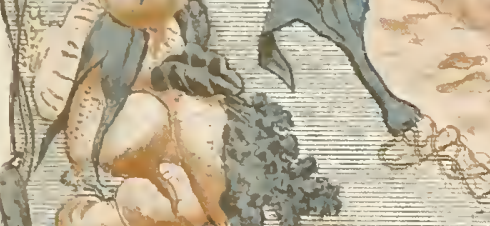

11 at

Deco
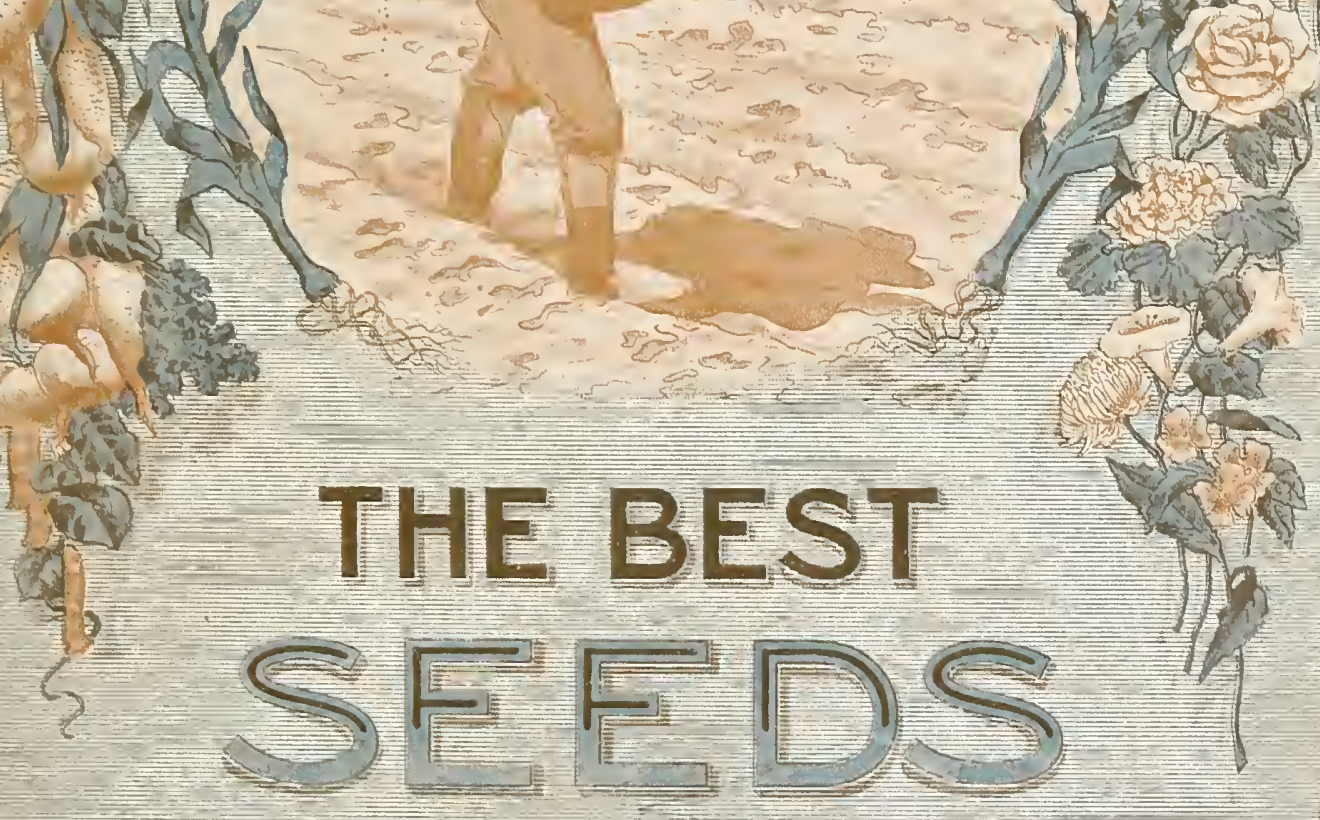


\section{To Our Friends and Customers:}

MeMphis, TExi., January 1, 1903. we believe to be more complete and interesting than any previous issue. The quality of our seeds is the very highest, and from those who do not know us we ask a trial order. We publish in this catalogue a few of the many unsolicited testimonials received during the past season. A pleased customer is always the best advertisenent. WVe thank you, our friends, one and all, for your most liberal patronage, and especially for that of the past year, which was almost double that of any previous season; and by treating you right we hope to merit your patronage for many years to come, and also to make many new friends. Wishing you much success and awaiting your commands with large or small orders, we remain,

Respectfully yours,

EstABLISHED 1869.

OTTO SCHWILL \& CO., Seedsmen,

Memphis, Tenn.

\section{Why it is to your advantage to intrust your orders to us:}

OUR COMPLETE STOCK makes it possib?e for customers to secure everything needed for the Farm and Garden, Orchard, Lawn, Flower Beds, Window Garden or Conservatory, in one order and at one shipment, ihereby saving a large per cent. of the express or freight charges that would be incurred by ordering frum a dozen localities.

SEED DEPARTMENT. Our immense Seed Warehouses and storage facilities give us unusual advantages in handling orders large or small at all seasons of the year, with the least possible delay. Having recently fitted our establishment with new and improved cleaning machinery, we are in a position to give our customers the best quality and cleanest seeds obtainable.

NURSERY DEPARTMENT. Our Nursery Department is one of the largest and the best equipped in the South. We grow only the best varieties suitable for the Southern climate and soil. It is no experiment business here. You can rest assured of getting trees that will grow and produce good fruit.

Catalogue of Plants in which will be found illustrated and described, with attractive prices, a full list of eous Plants, Flowering Shrubs, (postal card is sufficient) to anyone desiring it.

\section{The Only Really \\ Dwarf Salvia Splendens, "Lord Fauntleroy."}

The illustration is engraved from a photograph of one plant, measuring only 18 inches high from the ground to the tips of the spikes. It will at once be seen that for bedding this new Salvia is fully as suitable as geraniums in respect to height and compactness, while in brilliancy of color it eclipses anything in nature. The foliage is of a very rich dark green color, beginning right at the ground and rising no more than 10 inches above, while the 8.inch flower spikes stand erect and clear above the foliage. For bedding in masses alone, or with plants of equal heiglit, or for borders around beds of taller plants, we know nothing that will be so effective. Price, 25̃c per packet.

\section{Schwill's Special for Hay and Pas- Schroll's Special ture. Our hay and} Grass Mixture.... parture mix ture is

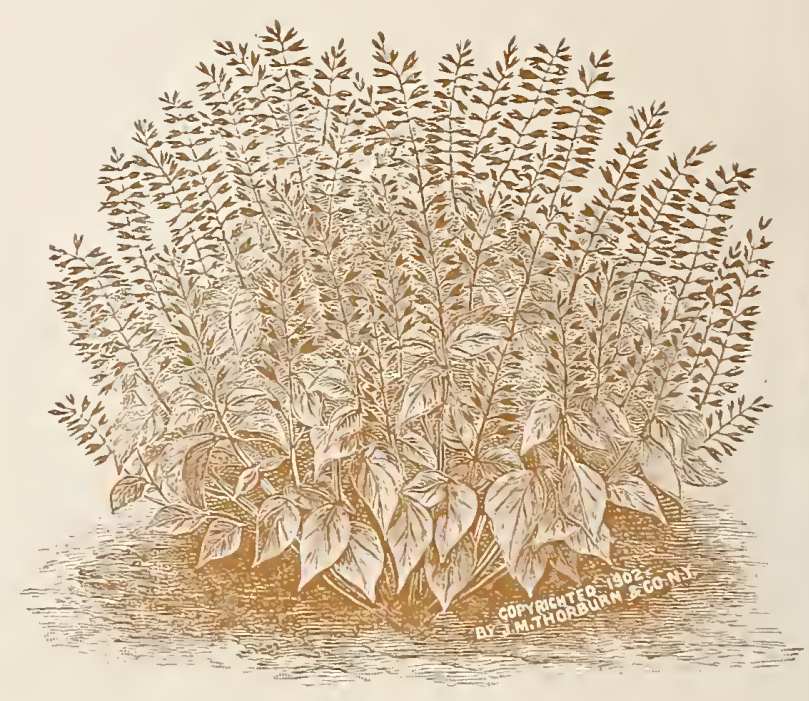

average need. It is made up of the grasies best calculated to afford an abundant and nutritious food supply for stock. Its formula is based upon successful experience. For all ordinary permanent pasturage it will be found entirely satisfactory. If your fields are old and worn out, it will pay to plow up and seed again, when yon will soon be cutting heavy crops from Schwill's Permanent Pasture Mixture. You will be able to cut two good crops each year, whereas from Timothy only you can cut but one. Sow two bushels to acre. In ordering state whether for light or heavy soil. Price, per lb. 30c, postage paid; by express, pk. 50c, bu. $\$ 1.7 .5,5$ bu. $\$ 7$.

\section{INDEX.}

Asparagus Seeds and loots... P'age

Baskets ......................................... 53

Books. ..............................17, 20, 22, 50

Clover Seed.................................... 19,49

('nw" Peas

Cotton seed.................................. ts

rollections, seeds and Plants...1s, 21,31 ,

Farm s.eeds................................... 44

Flower seeds................................ 12. 14

liertilimern.....

$17, \ldots 1$

Flower pots.

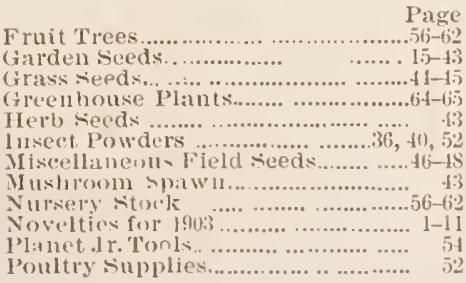

Potatoes, lrish and Sweet............. Page

Plants, Flowerin.

Plants, Vegetable............................ 29

Roots ind Esculents .................... 5.

ctrawberry l'lants........................ 56

siweet Peis lowats.....

storek lood

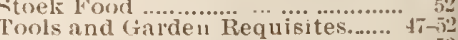

Twine...

Vegetable seeds.......................15-13

Vegetable Plants............................. 14,29 
ORDER SHEET FOR RELIABLE SEEDS, FINE SEED POTATOES, FERTILIZERS, FRUIT TREES, ETC.

\section{OTTO SCHWILL \& CO.}

\section{FRONT STREET,}

MEMPHIS, TENN.

Your Name

Postofice

Geunty

State

Haw to be Sent

If by Exp, or Frt, name office

Enelosed Please Find

P. 0. or Exp, Order, \$

Check, \$

Gash, $\$$

Siamps, $\$$

Total, $\$$

Be Sure to Fill in Above Blanks Properly. WRITE PLAIN

\begin{tabular}{l|l|l|l|l|l}
\hline QUANTITY & NAMES OF SEEDS, ETC., WANTED & PRICE \\
\hline & & & \\
\hline & & & \\
\hline
\end{tabular}

All Seeds Sold at 50 Per Packer, or 3 for 100 , Unless Otherwise Poted: 
PLEA3E WRITE each item of your order on a separate line, and carry out prices. Also please keep a copy of your order with which to "check off" the seeds when received, to be sure that you receive JUST WHAT YOU ORDHEED. We celdom make mistakes, but WHEN WE DO, want to be notified immediately, so that they can be corrected.

Kindly write any questlons, requiring answer, separately from the order.

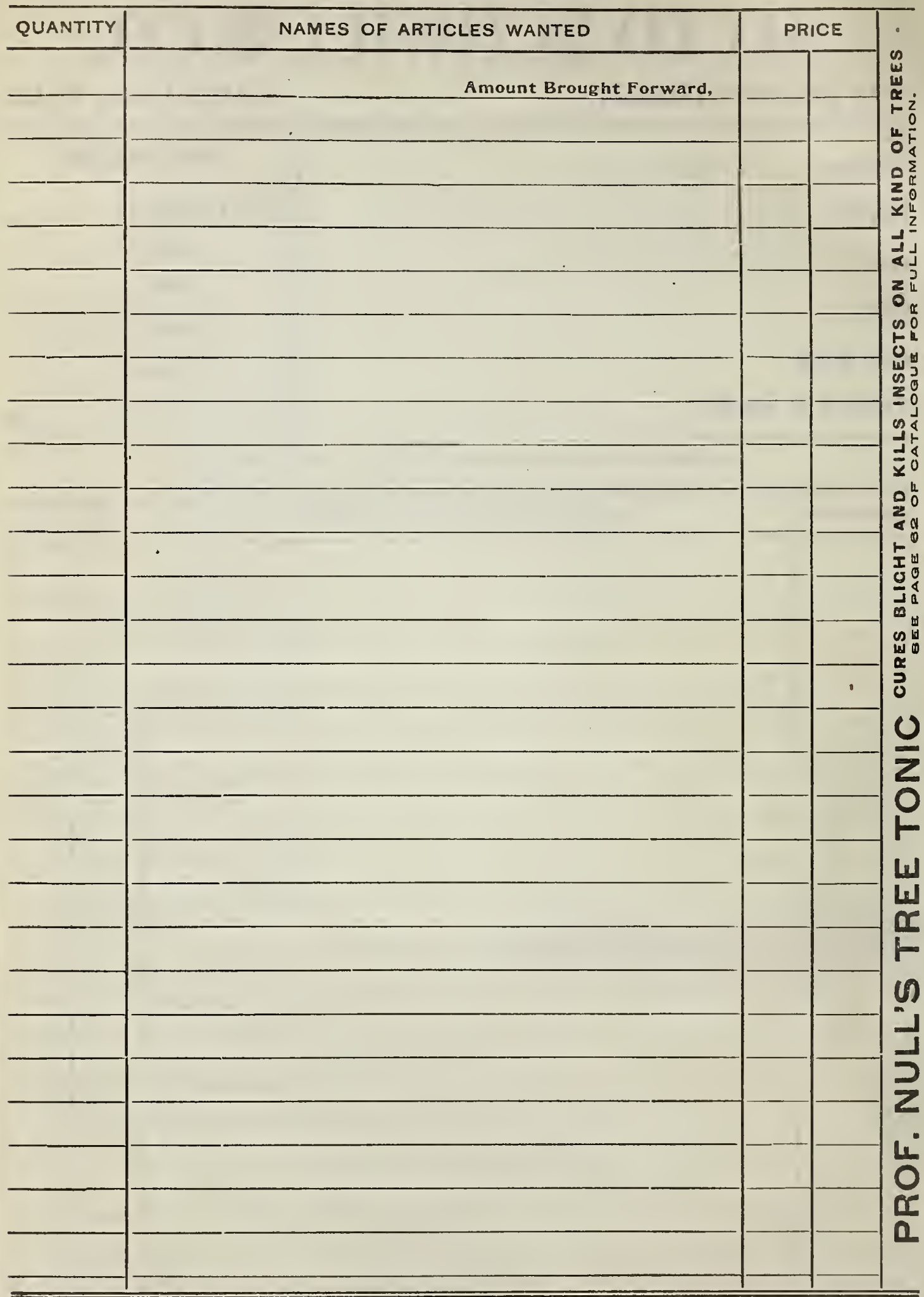




\section{Schwill's Novelties and Specialties in Seeds....}

OUR novelty list for 1903 contains the latest and best introductions of the season, together with some speclaities of other growers, which have proven of merit. Do not fall to include some of them in your orders. : :

\section{New Asparagus.}

Giant Argenteuil. Extra early, giant in size, extra long spears which are tender and of high flavor, and of pure whiteness. This new variety should be planted by everyone. Seed: Packet 10c, $\frac{1}{2}$ oz. $15 \mathrm{c}, 1 \mathrm{oz} .25 \mathrm{c}, \frac{1}{4} 1 \mathrm{~b} .75 \mathrm{c}, 1 \mathrm{lb} . \$ 2$, postage paid. Roots: Strong roots, by express only, doz. $25 \mathrm{c}, 25$ for $40 \mathrm{c}, 100$ for $\$ 1.50$, 1000 for $\$ 9$.

\section{Green Bush Beans.}

Lightning Earliest Valentine Bean. By careful selection for a number of seasons we have here a decided improvement over the old Valentine beans. Will ripen five to six days earlier than the old standby, which makes it the most desirable for market and shipping. Pods round and exceedingly productive. It's a money maker. Do not fail to plant this fine bean. Pkt. $10 \mathrm{c}, \frac{1}{2}$ pt. $15 \mathrm{c}$, pt. $25 \mathrm{c}$, qt. $40 \mathrm{c}$, postage paid; by express, qt. $25 \mathrm{c}, \frac{3}{2} \mathrm{pk} .75 \mathrm{c}$, pk. $\$ 1.25$, bush. $\$ 4.50$.

Bountiful. This is the most productive of all the green fleshed snap beans. A most desirable new sort, outyielding the Valentine, especially in mid-summer when the weather is hot; the Bountiful produces a full crop, which is the only one

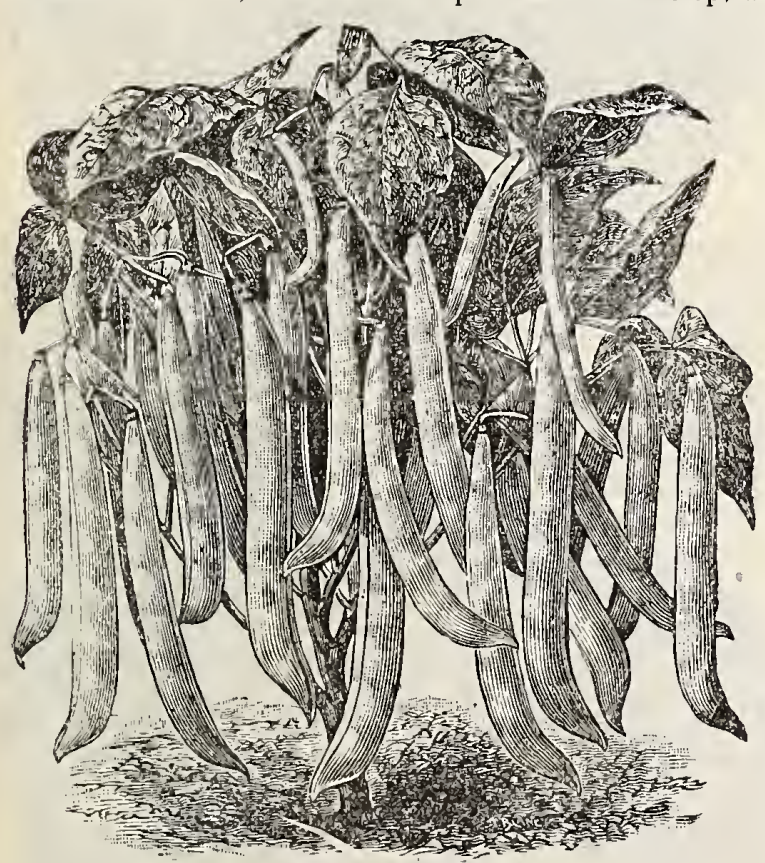

Green Bush Bean, Lightning Earliest Valentine. objection against the well known Valen. tine, viz : it does not make a crop in extreme hot weather.

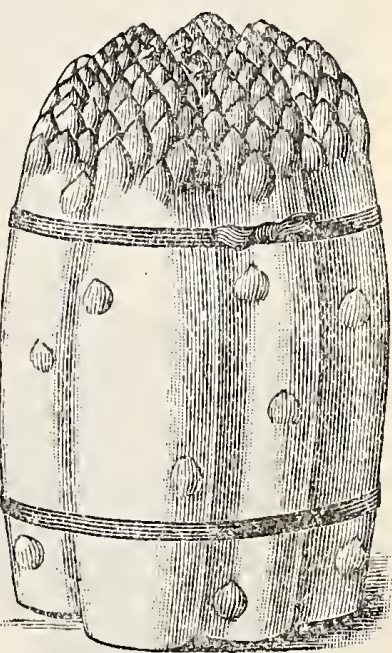

Giant Argenteuil Asparagus. Pods of this excellent variety are round, fleshy, full size and of highest flavor, always tender. Pkt. 10c, $\frac{1}{2}$ pt. $15 \mathrm{c}$, pt. $25 \mathrm{c}$, qt. $45 \mathrm{c}$, postage paid ; by express, qt. $30 \mathrm{c}$, $\frac{1}{2} \mathrm{pk} .90 \mathrm{c}, \mathrm{pk} . \$ 1.50$, bush. $\$ 4.50$.

\section{Wax Bush Beans.}

Jones' Stringless. A new dwarf variety with round, stringless pods of unsurpassed beauty and quality. Plant vigorous and exceedingly productive and very early. Pkt. $10 \mathrm{c}, \frac{1}{2} \mathrm{pt} .15 \mathrm{c}, \mathrm{pt} .25 \mathrm{c}$, qt. $45 \mathrm{c}$, postage paid; by express, qt. $30 \mathrm{c}, \frac{1}{2}$ pk. $\$ 1$, pk. $\$ 1.75$, bu. $\$ 6.50$.

\section{Bush Lima Beans.}

Dreer's Wonder. An excellent strain of the Bush Lima family which has given wonderful satisfaction, both in producing fine, large beans and in holding steadfastly to its dwarf habit, growing absolutely in a bush form without the least sign of a runner. Beans extra large size, and at the same time very early. No other Bush Lima Beans have such a record for earliness and size. Pkt. $10 \mathrm{c}, \frac{1}{2}$ pt. $20 \mathrm{c}$, pt. $30 \mathrm{c}$, qt. $50 \mathrm{c}$, postage paid ; by express, qt. $35 \mathrm{c}, \frac{1}{2} \mathrm{pk} . \$ 1.25$, pk. $\$ 2$.

\section{SATISFACTION GUARANTEED.}

We realize most fully that in the seed business-inore so than iu any other-_a pleased customer is the best advertisement," and onr undivided attention is given to satisfy onr patrons so that they will renain with us permanently. From past experience we are confident of our ability to please the most fastidious, amd all we ask of those who have not yet dealt with us is to send us a trial order and be convinced of the superior quality of our seeds and our fair and square method of doing business. 


\section{New Corn Field or Pole Bean.}

Powell's or Texas Wonder. An extraordinary snap bean, surpassing anything ever seen in our section - bearing profusely, and continuing until frost. The handsome green pods average eight or nine beans to the pod, grow very uniform, about six inches long, perfectly stringless, thick meated, rich and buttery; possess an exquisite flavor when cooked. It continues in bearing so long it might be called "Everbearing." Its strong points are: First-it produces twice as many string beans from the same ground as any bush kind. Second-grows in clusters: takes no time at all to gather a bushel; no stooping. Third-specially adapted to growing on corn, thus economizing space on valuable land, or where poles are scarce. Pkt. J0c, $\frac{1}{2} \mathrm{pt} .20 \mathrm{c}, \mathrm{pt}$. $35 \mathrm{c}$, qt. $65 \mathrm{c}$, postage paid.

\section{New Beet.}

True Dark Stinson. One of the best red turnip shaped varieties. Has small upright tops,

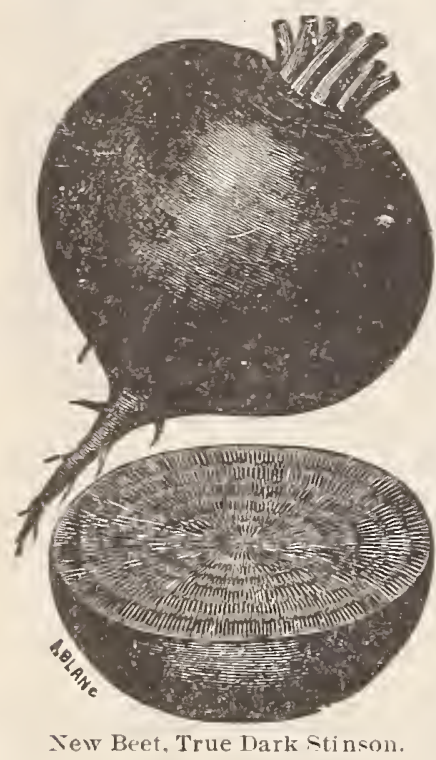
splendid shape. dark blood fles h, d e e p bright red, very crisp, te nder and sweet. Maearly and keeps well. Pkt. 5c, oz.10c, 2 oz. $15 \mathrm{c}$, 妾 $1 \mathrm{~b} .20 \mathrm{c}$, lb. $60 \mathrm{c}$, postage paid.

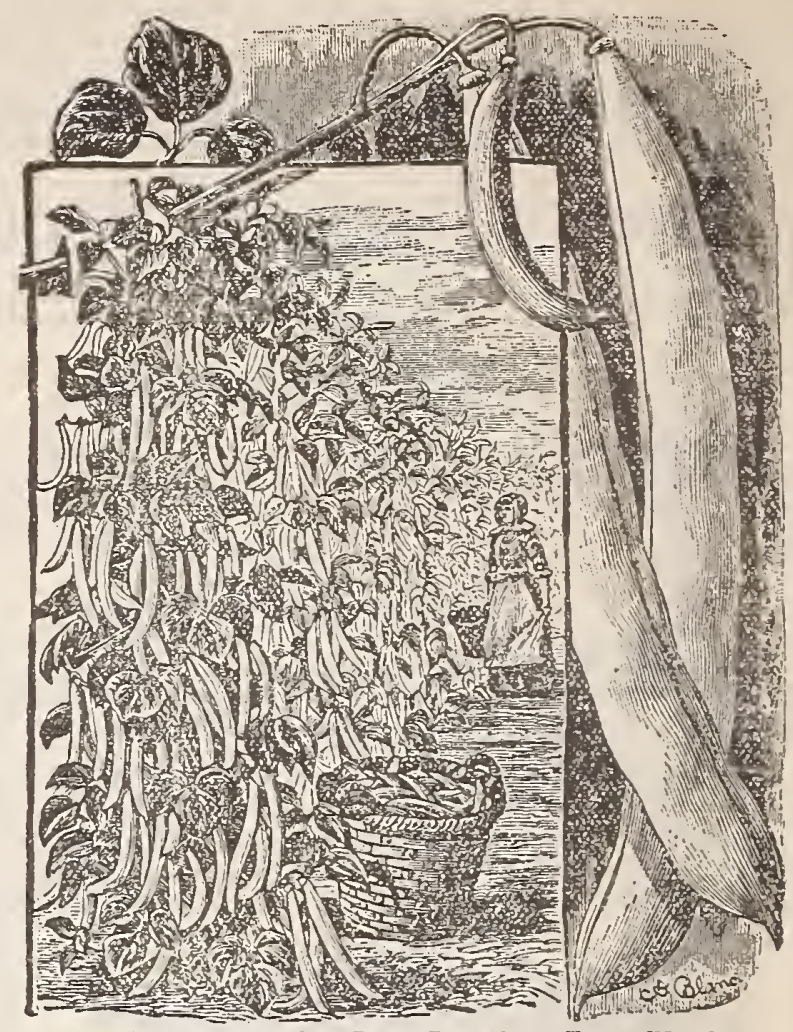

Tew Corn Field or Pole Bean, Powell's or Texas Wonder.

\section{New Cabbage.}

Extra Early Eureka. A wonderful variety of the best quality, produces good heads in serenty to ninety days. Heads flat, solid and keeps well. Pkt. $\bar{c}$. oz. 3.jc, $2 \mathrm{oz}, 60 \mathrm{c}$, $\frac{1}{4} \mathrm{lb}$. \$l, postage paid.

Worldbeater. One of the finest strains of late cabbage ever offered. It produces regular, even heads of enormous size, which keep well for a long period. Pkt. 5c, oz. 30c, 2 oz 50c, 1 lb. S.5c, lb. \$. .50, postpaid.

Schwill's Matchless Late Flat Dutch. One of the finest strain, of late cabbage ever introduced. Our market gardeners here will u=e no other. Pkt. jc, oz. $25 \mathrm{c}, 2 \mathrm{oz}, 45 \mathrm{c}, \frac{1}{\mathrm{l}} \mathrm{b}, 75 \mathrm{c}, \mathrm{Ib} .52 .25$, postage paid

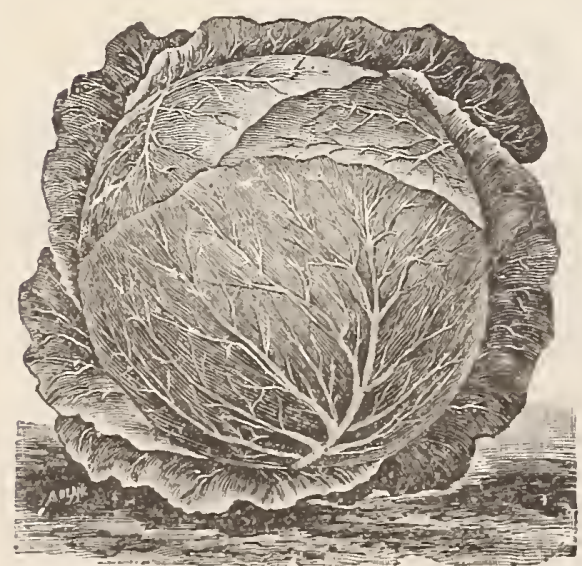

New Cabbage, Worldbeater.

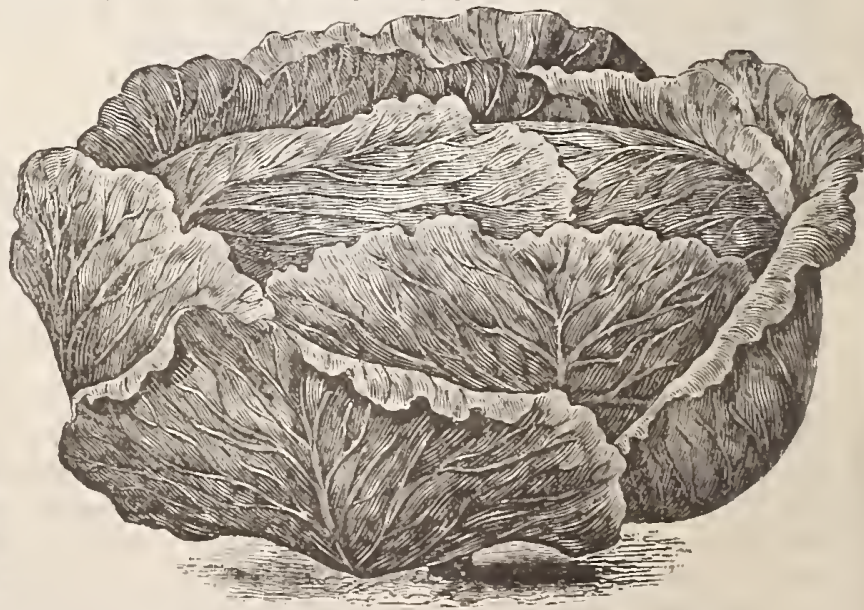

New Cabbage, Schwill's Matchless Late Flat Dutch. 


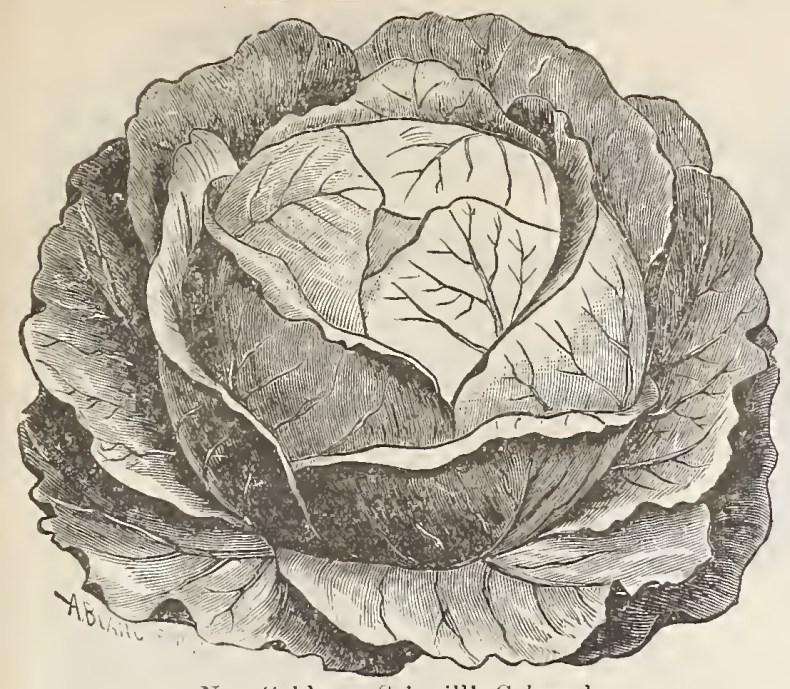

Yew C'abbage, Schwill's Colossal.

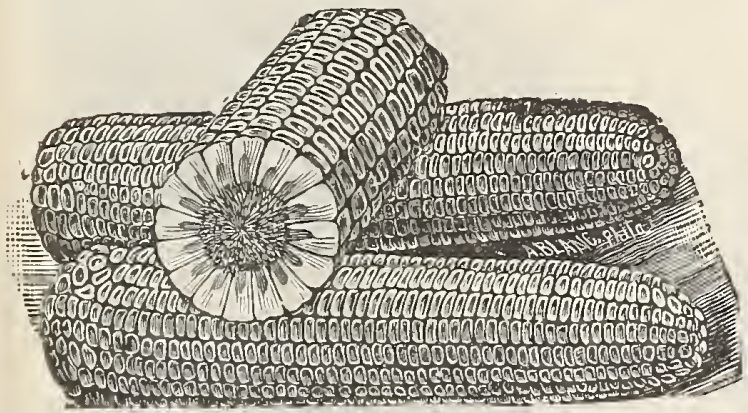

New Corn, Schwill's Early surprise.

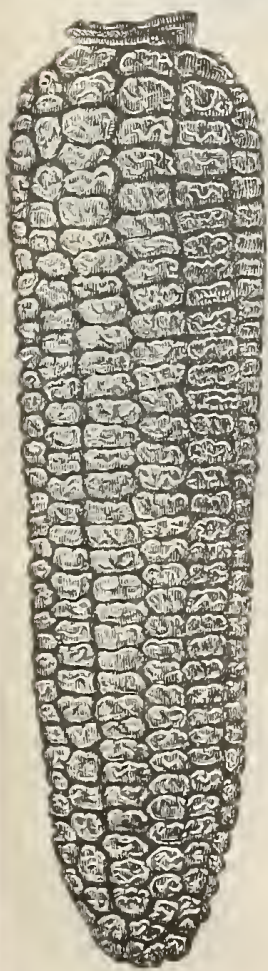

New Corn, Sehwill's Improved Large Adam
Few things are more expensive in the end than buying and planting clieap seed.
Brazilian Stooling or Flour Corn. A most prolific variety, stooling like wheat bearing six to eight ears of fine, large size grain., pure white. It also produces an im mense amount of fodder for feeding stock. Pkt. 10c, pt. 20c, qt. 30c, postage paid; by express, qt. $20 \mathrm{c}, \frac{1}{2}$ pk. $50 \mathrm{c}$, bu. $\$ 2.50$.

Snow White Dent. This new corn is by far the most valuable corn novelty of modern times. A drouth-beater in the Southern States, where it matures a big yield twenty to thirty days before severe dry weather. Ears very large size, with snow white deep grains. Cobs medium size, al white Snow White Dent will yield eighty bushels per acre, and as a superb milling corn it has no equal. Don't fail to try it. Pkt. 10c, pt. 20c, qt. 35̃c, postage paid ; by express, qt. 20c, pk. 75 c, bu. $\$ 2.50$.

\section{New Sweet Corn.}

Early Premo. Think of it! A sweet corn that is as early as Extra Early Adams. We have i.t here, and at the same time large ears than either the Adams or the Cory. Plant Premo for early market and you will not miss it. Pkt. 10c, pt. 25̄c, qt. $40 \mathrm{c}$, postage paid; by express, qt. $25 \mathrm{c}, \frac{1}{2} \mathrm{pk} .75 \mathrm{c}$ bu. $\$ 3.50$.
NEW CABBAGE-Continued.

New Early Spring. A valuable variety for extra early market. Heads as large as the Wakefield. Just the thing for gardeners. Pkt. 5c, oz. $80 \mathrm{c}, 2 \mathrm{oz} .50 \mathrm{c}$, lb. $85 \mathrm{c}$, postage paid.

Schwill's Colossal. Uniform in type, sure to head and immense in size and weight. Here is one of the surest heading and best late varieties on ourlist. Pkt. $5 \mathrm{c}$, oz. $30 \mathrm{c}, 2 \mathrm{oz}$.

$50 \mathrm{c}$, ? $\mathrm{lb}, 85 \mathrm{c}, 1 \mathrm{~b}$ $\$ 2.50$, postpaid.

Burpee's Safe Crop. Extremely matures late; fine for winter. Pkt. $5 \mathrm{c}$, 7 lb. $75 \mathrm{c}, 1 \mathrm{~b} . \$ 2.50$, postage paid.

All Seeds sold at 5̄c per packet, or 3 for $10 \mathrm{c}$, unless oth erwise noted.

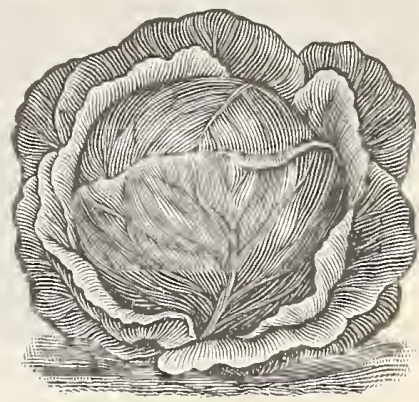

\section{New Corn.}

Schwill's Improved Large Adams. Larger than the ordinary strain of Adams' Early, and just as early. Ears always filled out to the end, making a handsome appearance for such an early corn. Pkt. $10 \mathrm{c}$, pt. $20 \mathrm{c}$, qt. $30 \mathrm{c}$, postage paid : by express qt. $20 \mathrm{c}$, $\frac{1}{2}$ pk. $50 \mathrm{c}$, pk. $90 \mathrm{c}$, bu. $\$ 3$.

Schwill's Early Surprise. Although not strictly a new variety, we list it here as one of the good things. It matures large, handsome ears for the early market, and no market gardener should be without it. Produces fine large roasting ears in seren weeks. Pkt. $10 \mathrm{c}$, pt. $20 \mathrm{c}$, qt. $35 \mathrm{c}$, postage paid : by express, qt. $20 \mathrm{c}$, $2 \mathrm{pk} .40 \mathrm{c}, \mathrm{pk}$. $75 \mathrm{c}$, bu. $\$ 2.50$.

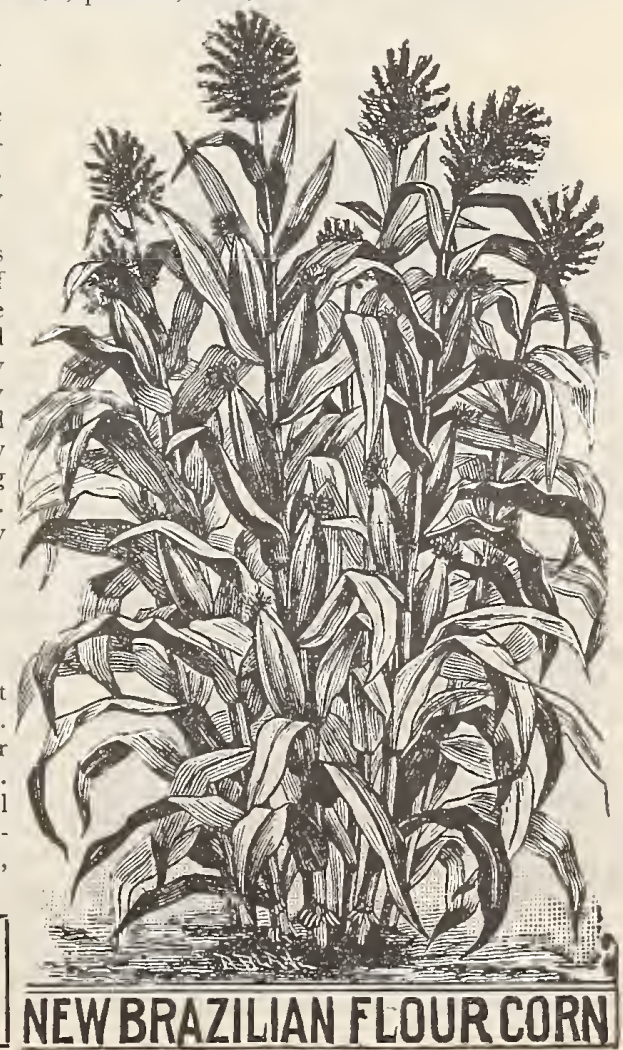



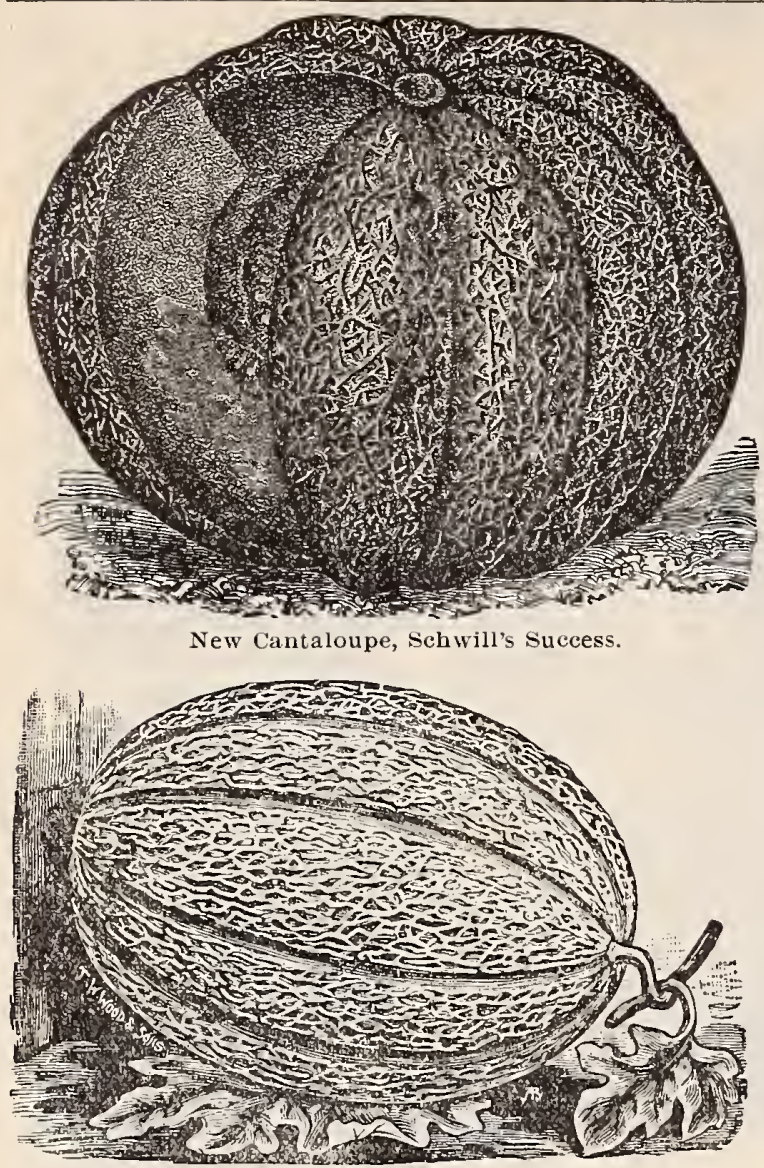

New Cantaloupe, Memphis Market.

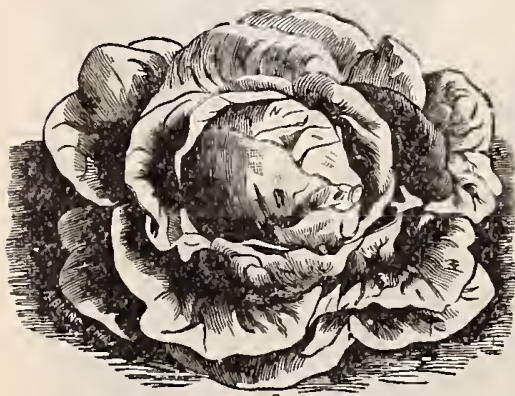

New Lettuce, Continuity.

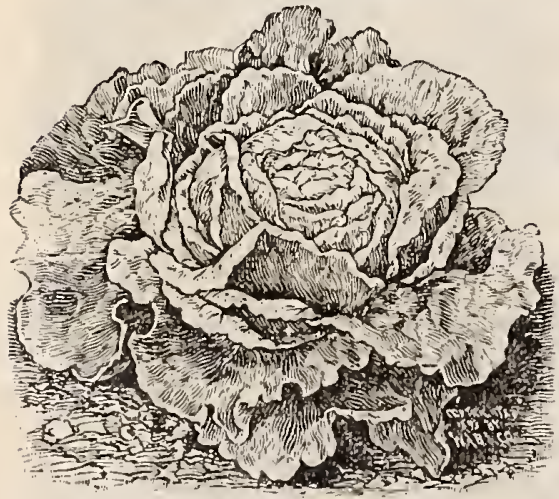

New Lettuce, Giant Crystal Head. paid. paid. l $\mathrm{lb} .70 \mathrm{c}$.

\section{New Cantaloupes.}

Schwill's Success. A general crop melon. Fruit large, round, finely netted; flesh green, thick and exceedingly sweet. A favorite on our home market. Pkt. $10 \mathrm{c}$, oz. $20 \mathrm{c}, 2 \mathrm{oz} .30 \mathrm{c}$, 交 lb. 50c, lb. $\$ 1.50$, postage paid.

Memphis Market. Has a beautiful, heavily netted green skin; shape a distinct oval and of good size. Some larger than the Baltimore or Acme. Very productive. Flesh green, very finely flavored, smooth and sweet. Pkt. $10 \mathrm{c}, \mathrm{oz} .20 \mathrm{c}, 2 \mathrm{oz} .30 \mathrm{c}, \frac{1}{4} \mathrm{lb} .50 \mathrm{c}, \mathrm{lb}$ $\$ 1.50$, postage paid.

Rocky Ford. Headquarters seed. One of the most productive melons in the world. It is of the netted gem type, oval in shape and beautifully netted. Flesh is juicy and rich greenish in color, and has a delightful aroma and fine flavor. Pkt. 5c, oz. 15c, 2 oz. 25 c, $\frac{1}{4}$ lb. 40 c, lb. $\$ 1$.

Market Gardeners give ns their trade becanse we give them reliable seeds only. What plenses them will please yon.

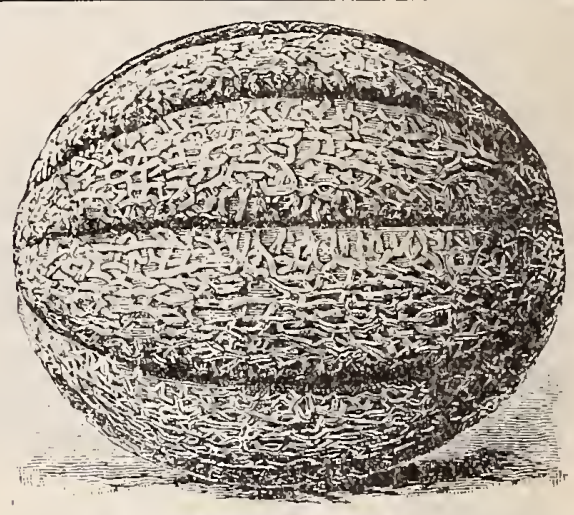

New Cantaloupe, Rocky Ford.

\section{New Cucumbers.}

New Orleans Market. A fine strain producing smooth, regular fruits of large size; skin a beautiful dark green color making it a handsome showy variety, excellent for pickle or slicing. Pkt. 5 c, oz. 20 c, 22 oz. 30 c, $\underset{4}{4}$ lb. 50 c, lb. $\$ 1.50$, postage

Thorburn's Everbearing. Medium size, very early, productive; also valuable as a pickle. Pkt. $5 \mathrm{c}, \mathrm{oz} .15 \mathrm{c}, 2 \mathrm{oz} .25 \mathrm{c},{ }_{4}^{1} \mathrm{lb} .40 \mathrm{c}, \mathrm{lb} . \$ 1.25$.

\section{New Lettuce.}

Giant Crystal Head. A new strain of cabbage lettuce, remarkable for size, firmness, weight and long-keeping qualities. Outside leaves are bright green, slightly fringed and tipped red. The inside

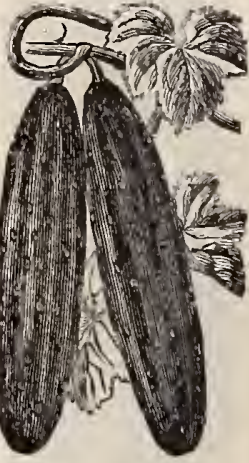

New Cucumber.

New Cucumber, is crystal white with a yellowish heart, of fine flavor and very crisp and tender. Pkt. 10c, $\frac{1}{2}$ oz. $25 \mathrm{c}$, oz. $40 \mathrm{c}, 2 \mathrm{oz} .70 \mathrm{c}, \frac{1}{4} \mathrm{lb} . \$ 1.25$, postage

Schwill's Hard Head. One of the best lettuces for all purposes. Forms medium size heads, compact and solid; leaves thick, rich and nutty in flavor. Our sales of this variety to market gardeners are constantly increasing. Pkt. 5c, $\frac{1}{2}$ oz. $15 \mathrm{c}$, oz. $25 \mathrm{c}, 2 \mathrm{oz} .40 \mathrm{c}, \frac{1}{4} 1 \mathrm{~b} .60 \mathrm{c}$.

Continuity. A most beautiful, attractive lettuce of the cabbage type. Heads are solid, of immense size when well grown, and so exceedingly tender and brittle as to fully warrant everyone to plant it. Superior family and home market lettuce. Pkt. 10c, $\frac{1}{2}$ oz. $15 \mathrm{c}$, oz. $25 \mathrm{c}, 2$ oz. $40 \mathrm{c}$. 
NEW LETTUCE-Continued.

Summerlead. Do not fail to try this splendid new introduction as shown in the illustration. It is one of the finest, large, solid heading varieties on our list. Leaves smooth, bright green and makes an attractive appearance. In all respects Summerlead is an ideal lettuce. Pkt. 5c, $\frac{1}{2}$ oz. $15 \mathrm{c}$, oz. $25 \mathrm{c}, 2 \mathrm{oz} .35 \mathrm{c}, \frac{1}{4} 1 \mathrm{lb} .60 \mathrm{c}$, postpaid.

\section{New Mustard.}

Chinese Mammoth. A giant curled variety with leaves double the size of the ordinary kinds. Forms mammoth bunches and leaves are exceedingly tender at all times. Pkt. 5c, oz. $15 \mathrm{c}, 2 \mathrm{oz}$. 25 c, $\frac{1}{4}$ lb. 40 c, lb. 90 c, postage paid.

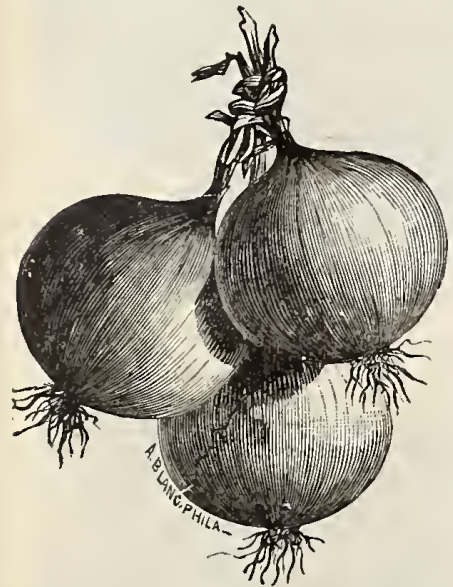

New Onion Ohio Yellow Globe.

\section{New Onions.}

Ohio Yellow Globe. A most perfect type of pure globe shaped onions, golden yellow in color, solid and a most ex cellent keeper. Its handsome shape, bright, even color and enormous yielding qualities puts this sort at the head of the list. Pkt. 5c, $\frac{1}{2} \mathrm{oz} .10 \mathrm{c}, \mathrm{oz}$. $15 \mathrm{c}, 2 \mathrm{oz} .25 \mathrm{c}, \frac{1}{+} \mathrm{lb} .45 \mathrm{c}, 1 \mathrm{lb}$. $\$ 1.30$, postage paid.

Extra Early Red Globe. Deep red color, close grain, solid and heavy, and matures fully three weeks sooner than the ordinary Southport Red Globe. Pkt. 5c, $\frac{1}{2}$ oz. $10 \mathrm{c}, \mathrm{oz}$. $15 \mathrm{c}, 2$ oz. 25c, 1 lb. $45 \mathrm{c}, \mathrm{lb}$. $\$ 1.40$, postage paid.

Australian Brown. This new onion is of neat, round shape, medium size, with skin of a deep amber brown, and will keep almost indefinitely. Pure American grown seed. Pkt. 5c, $\frac{1}{2} \mathrm{oz}$. 10c, oz. 20c, 능 oz. 30c, $\frac{1}{4}$ lb. 50c, lb. $\$ 1.60$.

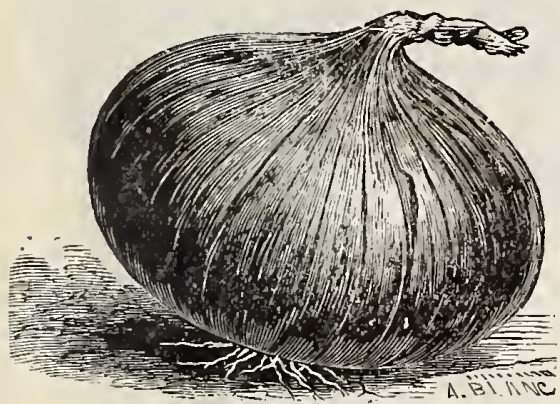

New Onion, Australian Brown.

\section{New Okra.}

Sterling white

Velvet. A distinct species, being a decided improvement over the ordinary White Velvet. Its handsome round, smooth pods are pearly white and always tender and succulent. For market or home use you should buy no other. Pkt. $5 \mathrm{c}$, oz. $10 \mathrm{c}, 2$ oz. $15 \mathrm{c}, \frac{1}{4} 1 \mathrm{~b} .25 \mathrm{c}, 1 \mathrm{~b}$. $50 \mathrm{c}$, postage paid.

Perkins' Mammoth Pod. In productiveness this new Okra is simply wonderful. Pods of an intense green color, and do not get hard as is the case with some other sorts. Pkt. 5c, oz. 10c, 2 oz. $15 \mathrm{c}, \frac{1}{4}$ lb. 25 c, lb. $60 \mathrm{c}$, postpaid.

TAYLors, Miss., May 20, 1902.

GentLemen:- Your seeds are the best I ever planted. They not only come up well, but they produce what you claim for them. Put me down as a regular customer.

R. C. STITH.

Leota, Washington County, Miss., August 4, 1902.

Gentlemen:--Your seeds are fine and give great satisfaction. MISS LOUISE BUCKNER.

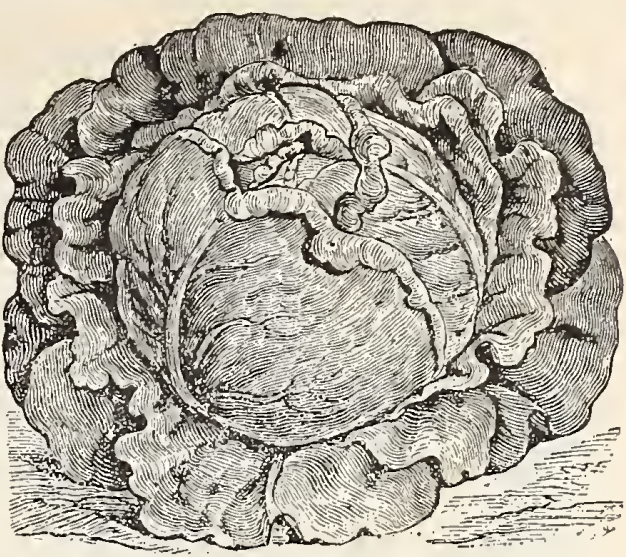

New Lettuce, Summerlead.

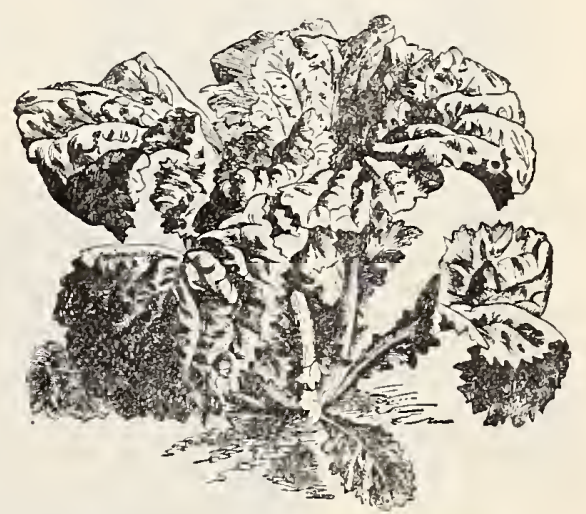

New Mustard, Chinese Mammoth.

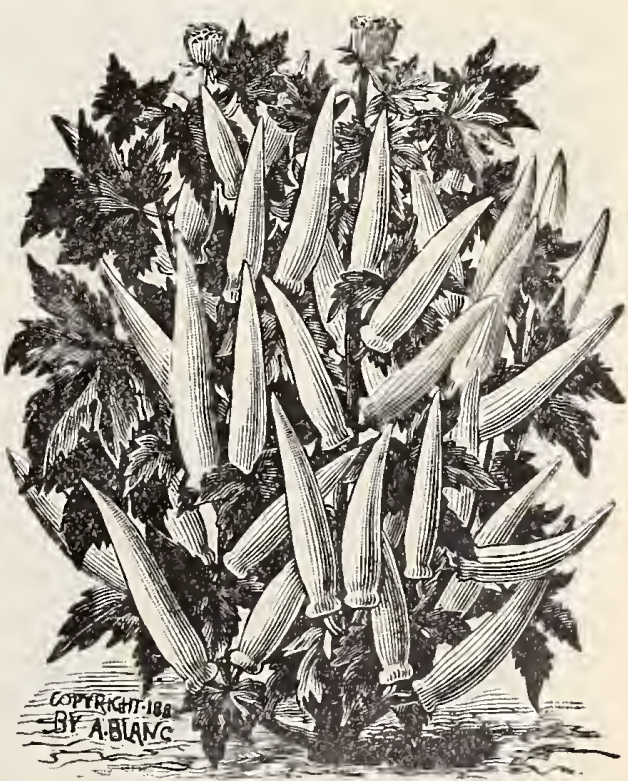

New Okra, Sterling While Velvet.

We Pay Postage on all Vegetable and Flower Seeds offered in this list by the packet, ounce, quarterby mail, postage prepaid. Always state how you wish goods sent-by mail, express or freight. 


\section{New Watermelons.}

Harris' Earliest. A new extra early variety, which ripens ten days ahead of any other sort. Think of it! Ripe melons in seventy days from planting of the seed. It is the melon to plant for profit. It will ripen and be gone before common melons begin to ripen. We have never seen its equal. Melons very good size for an extra early variety, weighing from fifteen to twenty pounds; flesh bright red, juicy and sweet. Seed is very scarce, so order early before stock is disposed of. Pkt. $10 \mathrm{c}, \mathrm{oz}$. $20 \mathrm{c}, 2 \mathrm{oz} .30 \mathrm{c}, 1 \mathrm{lb} .50 \mathrm{c}, 1 \mathrm{~b} . \$ 1.50$, postage paid.

Pure Kleckley Sweets. The finest table melon to grow for the home garden. Long, oval shape, dark'green rind; seeds white and lie close to the rind, and the flesh is deep red and the sweetest thing you ever tasted, and flavor simply delicious. Seeds very scarce this season. Pkt. 5c, oz. 20c, 2 oz. 35c, $\frac{1}{4} \mathrm{lb}$ 50 c, lb. $\$ 1.50$, postage paid.

Memphis. (Southern grown seed.) This is a very large, beautiful melon, of lightish color. The fiesh is brilliant red, and it is remarkably crisp, sweet and delicious. It is very well adapted to the South, and has the credit of being excellent for both market and family garden. Is a vigorous, rapid grower, and remarkably productive. Pkt. 10c, oz. 20c, 2 oz. 35c, \& $\mathrm{lb}$. $50 \mathrm{c}, \mathrm{lb} . \$ 1.50$, postage paid.

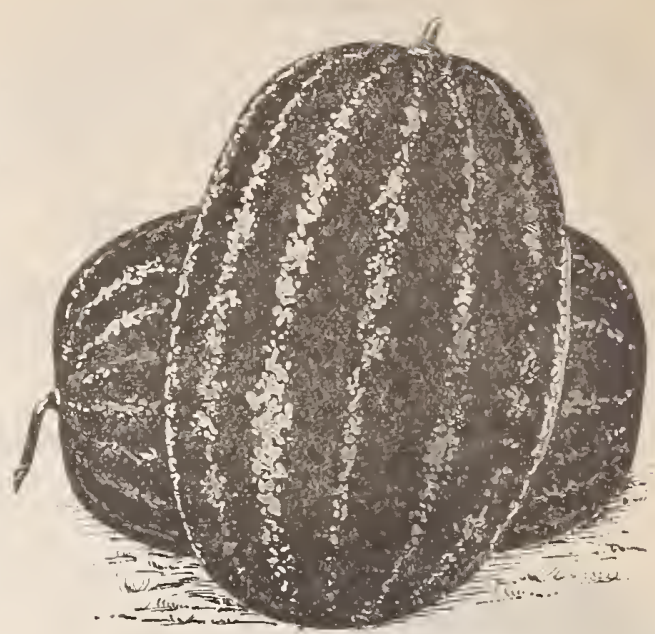

New Watermelon, Harris Earliest.

Branch's Superb Rattlesnake. (Southern grown seed.) A superior strain of the well. known Rattlesnake, grows larger, more uniform and is pure bred stock. Rind is thin and tough; the flesh is deep scarlet, and the flavor unsurpassed by any other sort. Pkt. 5c, oz. $15 \mathrm{c}, 2 \mathrm{oz} .25 \mathrm{c}, \frac{3}{+} \mathrm{lb}$. $40 \mathrm{c}, \mathrm{b} . \$ 1.15$, post. age paid.

Southern Sugar Loaf. (So u thern grown seed.) Greenish white or gray rind; flesh bright red and very sweet; large, long and one of the best to grow for market. Pkt: 5c, oz. 1 万丂 $\mathrm{c}, 2$ oz. $25 \mathrm{c}, \frac{1}{4}$ lb. $40 \mathrm{c}, \mathrm{lb}$. $\$ 1.25$. postage paid.

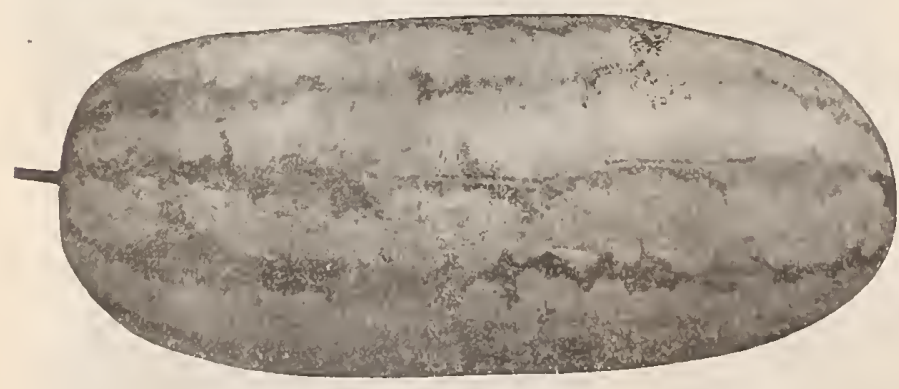

New Watermelon, Branch's Superb Rattlesnake.
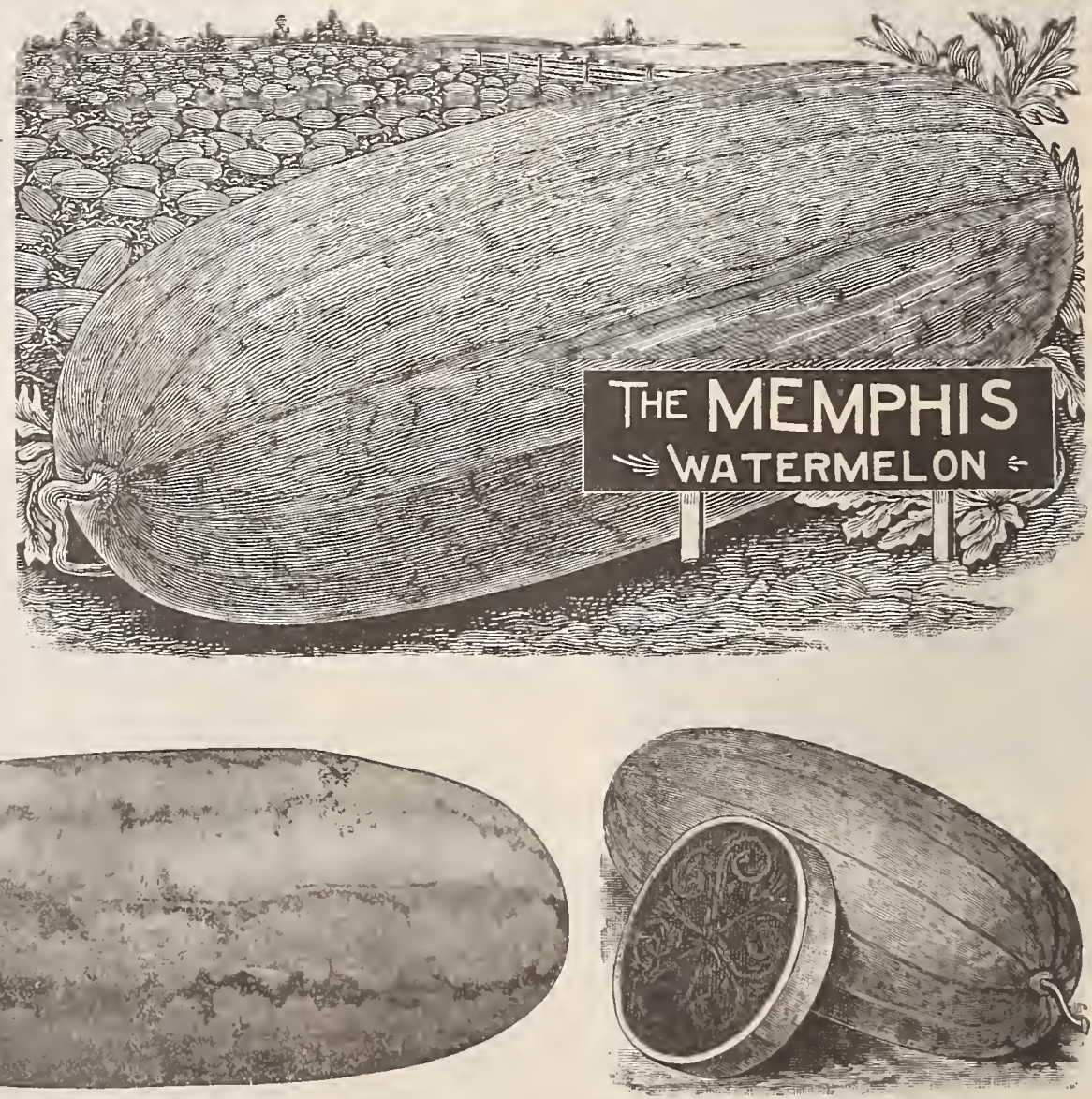

New Watermelon, southerı sugar Loaf.

\section{Five New Watermelons}

ONE PACKET EACH OF THE ABOVE FIVE VARIETIES OF WATERMELON SEED FOR....... $\left\{\begin{array}{l}\text { Twenty=five cents } \\ \text { Postage Paid........ }\end{array}\right.$ 


\section{New English Peas.}

Market Master. A new extra early, mammoth podded variety. Think of it! In earliness it is within a day or two of Alaska, but with pods double the size, and of a rich, dark green color. Pods contain seven to eight peas of the richest flavor, which are produced in the greatest abundance. Pkt. 15ic, $\frac{1}{2}$ pt. $25 \mathrm{c}$, pt. 35c, qt. 60c, postage paid.

Schwill's Early Market. One of the most profitable for the gardener and shipper because it is very early, ripens uniformly seven weeks from planting; at one picking the crop is on the market when the price is best. Pods handsome, straight and full of medium size round peas, which are sweet and tender. Pkt. $10 \mathrm{c}, \frac{1}{2} \mathrm{pt} .15 \mathrm{c}, \mathrm{pt} .25 \mathrm{c}, \mathrm{qt} .45 \mathrm{c}$, - postage paid; by express, qt. 30c. $\frac{1}{2}$ pk. $\$ 1$, bu. $\$ 6.50$.

Schwill's Family Queen. Continues in bearing a long time ; just the variety for home gardens, vines hardy, vigorous and productive, and they do not burn or scald like the very extra early sorts. Pods are large and contain from seven to ten peas, which are pale green, tender and deliciously sweet. Pkt. 10c, 15 pt. 15c, pt. 25c, qt. 40c, postage paid; by express, qt. $25 \mathrm{c}, \frac{1}{2} \mathrm{pk}, 75 \mathrm{c}$, bu. $\$ 5.50$.

Extra Early Surprise. One of the earliest wrinkled varieties, and at the same time just as hardy as the Alaska, as it can be planted jusi as soon. Wonderfully productive, vines grow twenty-four inches high, need no bushing and the pods are well filled with sweet peas. Quality, quantity and earliness combined in the new Extra Early Surprise. Pkt. 10c, $\frac{1}{2}$ pt. $15 \mathrm{c}$, pt. $25 \mathrm{c}$, qt. $45 \mathrm{c}$, postage paid; by express, qt. $30 \mathrm{c}$, pk. $\$ 1$, bu. $\$ 6.50$.

\section{New Peppers.}

Chinese Giant. Has extremely large and handsome pods, which are sweet and mild Fine for salad, as it does not partake of any of the strong pungent taste so common to the ordinary varieties. $\mathrm{Pkt} .15 \mathrm{c}$, $0 z .75 \mathrm{c}, 0 z . \$ 1.25$, postage paid.
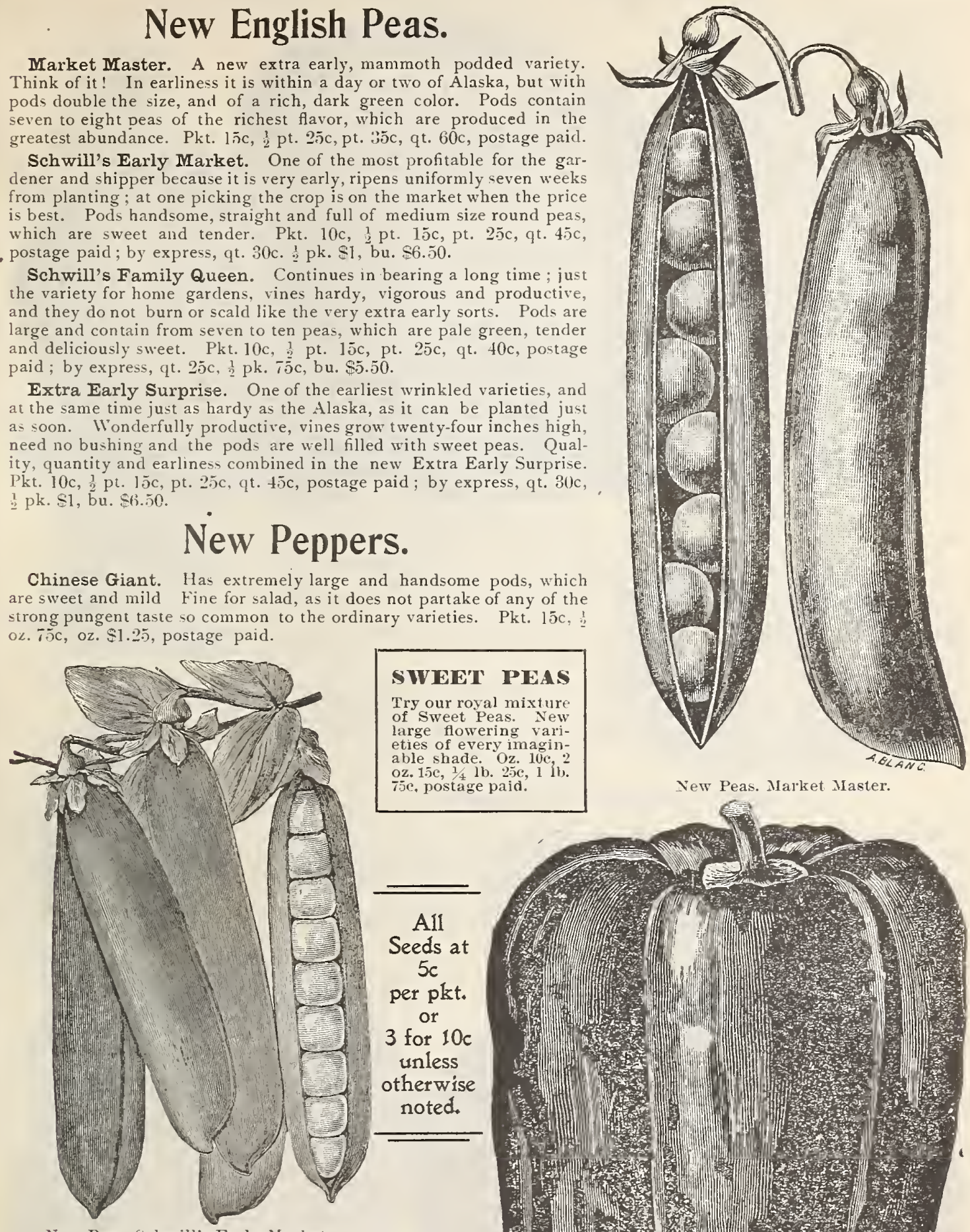

75e, postage paid.
New Peas. Market Master.

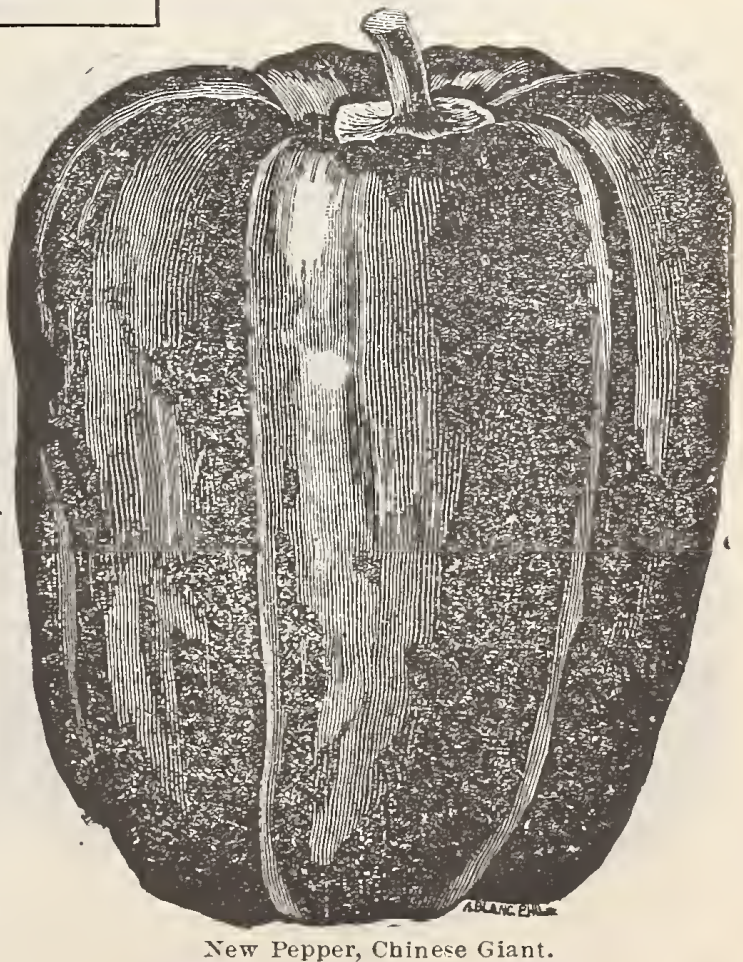

\section{Mixed Chicken Feed for Poultry.}

We have prepared a mixture of grain and seeds, such as Buckwheat, Millet, Wheat, Cracked Corn, Oyster Shell, etc. Best food in the market. Will make your hens lay. Tlie rariety does the work. While present stock lasts, bag of 100 lbs. $\$ 1.75$. 


\section{New Potatoes.}

\section{Quick Crop. As the} name implies, is an early variety. It is a rapid, vigorous grower. Cooking qualities unsurpassed. The tubers are oval to long in shape, light rose in color. We especially recommend this new variety to market gardeners' trade and to the home garden for first early. Pk. 60c, bu. $\$ 2$, bbl. $\$ 4.50$.

Earliest Six Weeks. Also recommended for early marketing, unsurpassed by any in quality, as it cooks dry and mealy as soon as the tubers have attained a marketable size. Tubers flesh colored, oval, oblong, uniform in size and good keepers. $\mathrm{Pk}$. $60 \mathrm{c}$, bu. $\$ 1.60$, bbl. $\$ 3.75$.

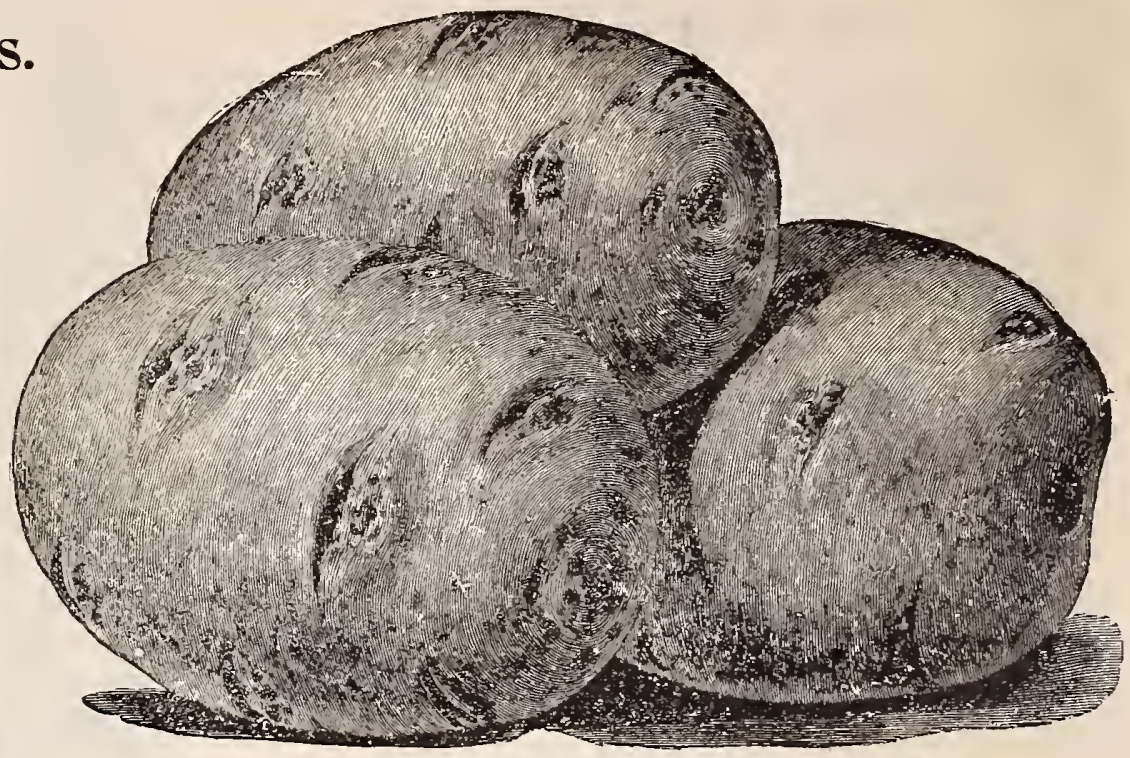

New Potato, Quick Crop.

Our Welcome. A home grown variety, pure white in color, round in shape, and has proven with us the best and heaviest cropper of any. To those who object to the Triumph on account of its red skin, we recommend this splendid new potato as the best round white variety for general cultivation. It has but few eyes, they are very shallow. The skin and flesh are very white and its cooking qualities the very best. We are pleased to offer our customers Tennessee second crop seed of this most excellent potato. $\frac{1}{2}$ pk. 50c, pk. $75 \mathrm{c}, \frac{1}{2}$ bu. $\$ 1.25$, bu. $\$ 2.25$.

Burpee's Extra Early. From ten days to two weeks earlier than Early Rose or Early Ohio. Oblong in form, very smooth skin, creamy white slightly shaded with pink. It is a sure cropper, immensely productive. Our trials of Burpee's Extra Early have proven it to be one of the very best early sorts. Pk. $60 \mathrm{c}$, bu. $\$ 1.60$, bbl. $\$ 3.50$.

\section{New Sweet Potatoes.}

Spanish Bunch Yam. This is entirely different from the Bunch Yellow Yam potatoes, being earlier, far more productive, and is also a fine eating variety; matures as early as the Old Southern Queen, just as prolific, but is a better and sweeter table potato; a splendid keeper, and just the thing for early market use. Seed is very scarce again this year. Send in your orders early. We will book same and ship about the 15 th of March. We do not send them out any earlier. $\frac{1}{2} \mathrm{pk} .50 \mathrm{c}, \mathrm{pk} .75 \mathrm{c}, \frac{1}{2} \mathrm{bu} . \$ 1.25$, bu. $\$ 2$.
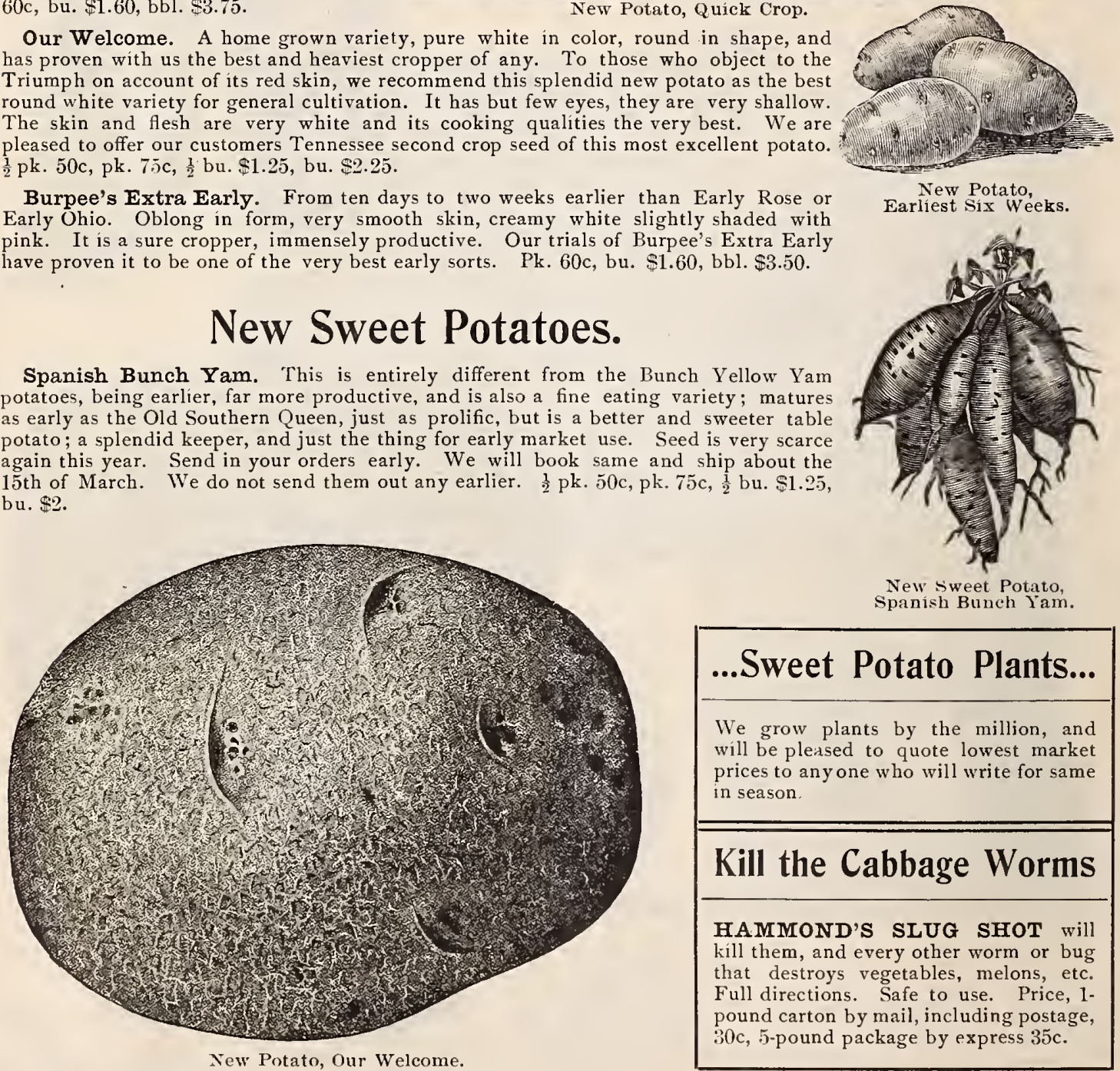

New Potato,

Earliest Six Weeks.

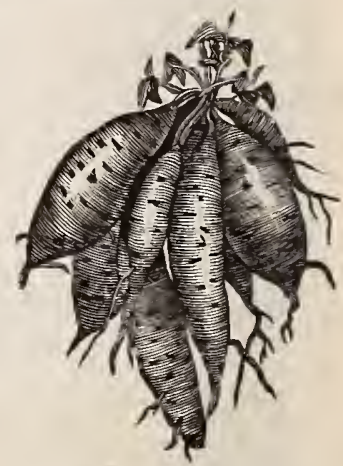

New sweet Potato,

Spanish Bunch Yam.

\section{...Sweet Potato Plants...}

We grow plants by the million, and will be pleased to quote lowest market prices to anyone who will write for same in season.

\section{Kill the Cabbage Worms}

HAMMOND'S SLUG SHOT will kill them, and every other worm or bug that destroys vegetables, melons, etc. Full directions. Safe to use. Price, 1pound carton by mail, including postage, $30 \mathrm{c}, 5$-pound package by express $35 \mathrm{c}$. 


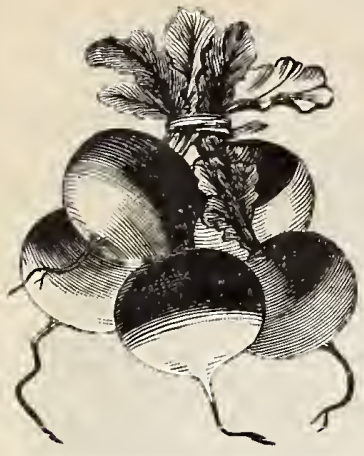

New Radish, Ruby Pearl.

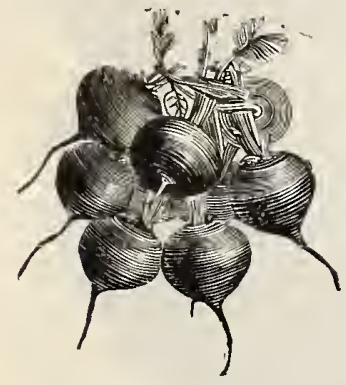

New Radish, Schwill's Rosy Gem.

\section{New Radishes.}

Queen of the Market. Market gardeners' improved strain. For forcing in the hotbed or cold frames there is no better paying variety than this splendid new radish. It makes a small top and forms bright round scarlet roots, which are of the very finest quality, always mild and crisp. Sown in the open ground in early spring will produce beautiful radishes in twenty-one days. Pkt. 5c, oz. 10c, 2 oz. 15 c, $\frac{1}{4}$ lb. 25 c, lb. $85 \mathrm{c}$, postage paid.

Ruby Pearl. A beautiful, quick growing radish ready for the table in twenty-four days. Shape, round ; handsome red color, with white tipped on the bottom, flesh white and mild. Pkt. $5 \mathrm{c}$, oz. $10 \mathrm{c}, 2 \mathrm{oz} .15 \mathrm{c}, \frac{1}{4} \mathrm{lb} .25 \mathrm{c}, 1 \mathrm{~b} .85 \mathrm{c}$, postage paid.

Schwill's Rosy Gem. One of the earliest rich deep scarlet, blending into pure white at the bottom, perfectly globular, exceedingly tender and crisp. Desirable for market and home garden. Pkt. 5c, oz. 10c, 2 oz. $15 \mathrm{c}, \frac{1}{4}$ lb. 25c, lb. 85 c.

The Snowball Radish. One of the quickest growing, besides one of the prettiest ever put on a gardener's bench. White as snow and smooth as glass. Has only a few short leaves. Pkt. 5c, oz. 10c, $\frac{1}{4}$ lb. $25 \mathrm{c}, \mathrm{lb} .80 \mathrm{c}$.

\section{New Turnips.}

Extra Early White Milan. A marvel of earliness, in fact, the earliest variety in cultivation. Tops upright, very small and compact, permitting of close planting; roots, pure white, very smooth, symmetrical and beautiful. Flesh, snow white, delicate in flavor, tender and sweet. A heavy yielder, good shipper and keeper. Pkt. 5c, oz. 10c, 2 oz, $15 \mathrm{c}, \frac{1}{4}$ lb. $20 \mathrm{c}, 1 \mathrm{~b} .75 \mathrm{c}$.

Early Snowball Turnip. A most beautiful medium-sized, round, pure white variety of excellent flavor. For early sowing this is one of the best, being crisp, tender and sweet, maturing in six weeks from the time of sowing. Pkt. 5c, oz. $10 \mathrm{c}, \frac{1}{4}$ lb. $25 \mathrm{c}, \mathrm{b} .75 \mathrm{c}$.

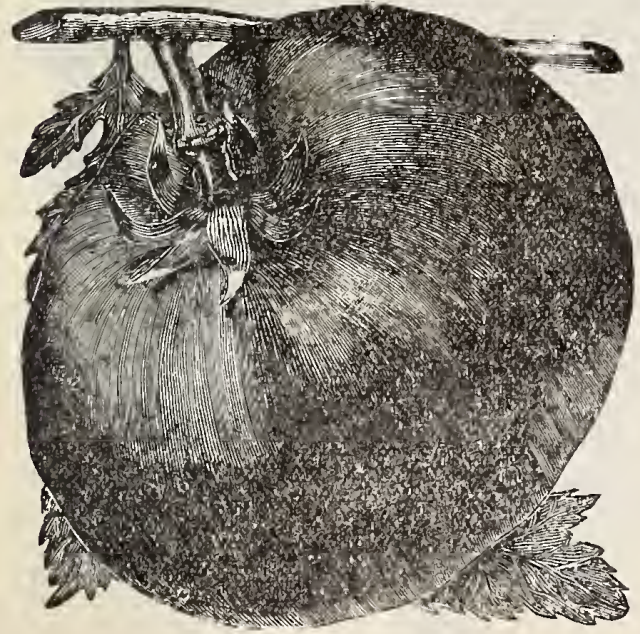

New Tomato, Quarter Century.

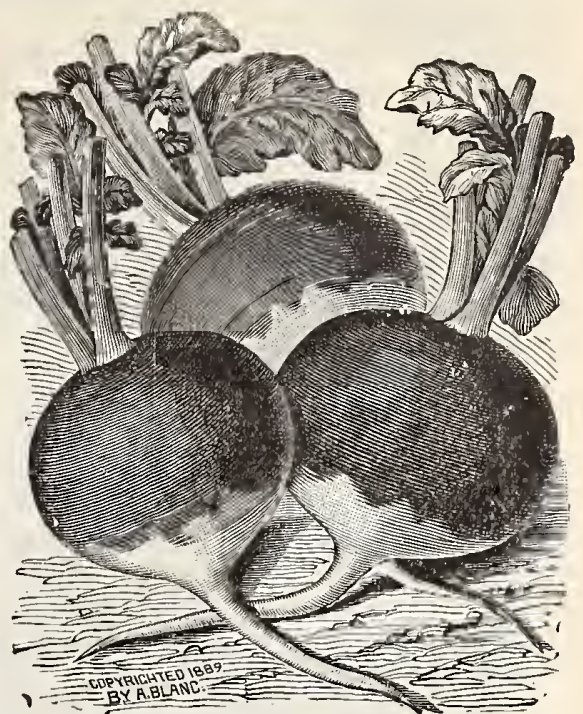

New Radish, Queen of the Market.

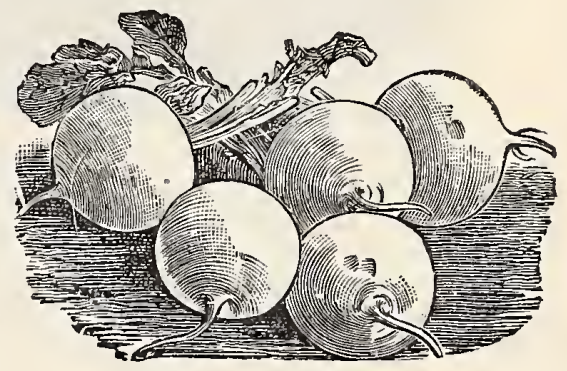

Early Snowball Turnip.

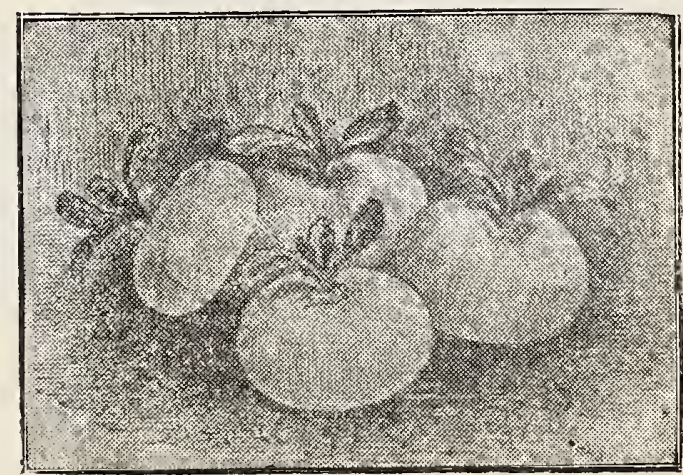

Extra Early White Milan Turnip.

\section{New Tomato.}

Quarter Century. Solid bright red. The best of all the dwarf growing, upright or tree-like tomatoes. Greatly superior to Dwarf Champion in size, productiveness and quality. Its large fruit is always smooth, free from cracks, very solid and meaty, having very small seed cavities. Quarter Century is a distinctly early ripening variety ; the young plants being sturdy and robust, standing erect without stakes. Pkt. $10 \mathrm{c}, 3$ pkts. $25 \mathrm{c}$, $\frac{1}{2}$ oz. $35 \mathrm{c}$, oz. $65 \mathrm{c}$. 


\section{New Tomatoes.}

Sparks' Earliana. The earliest of all, having been tested alongside of seventy other varieties, and has proven itself five to seven days ahead of any other variety. Fruit good size, bright red color, smooth and handsome. Earliana is a money maker for the gardener. Pkt. 10c, $10 z$. $25 \mathrm{c}$, oz. $50 \mathrm{c}, 2 \mathrm{oz} .75 \mathrm{c}$, 条 lb. $\$ 1.25$, postage paid.

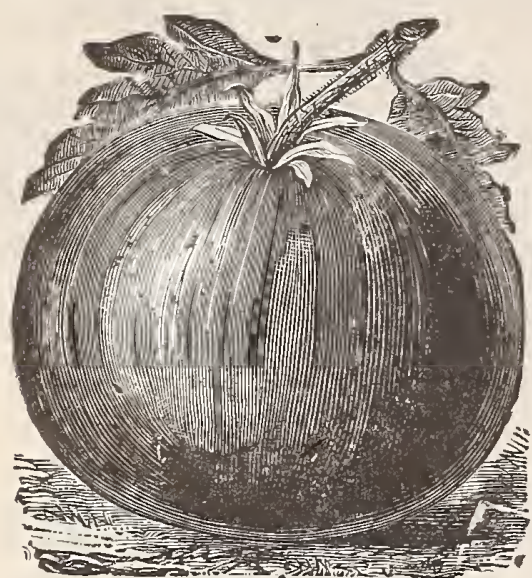

New Tomato, Spark's Earliana.

Success. A magnificent new scarlet fruited tomato. Ripens medium early and yields throughout the whole season abundantly. Its handsome color, very large size and great smoothness and solidity will make it a fine market variety. Pkt. 10c, oz. $25 \mathrm{c}$, oz. $50 \mathrm{c}, 2 \mathrm{oz} .90 \mathrm{c}$, postage paid.

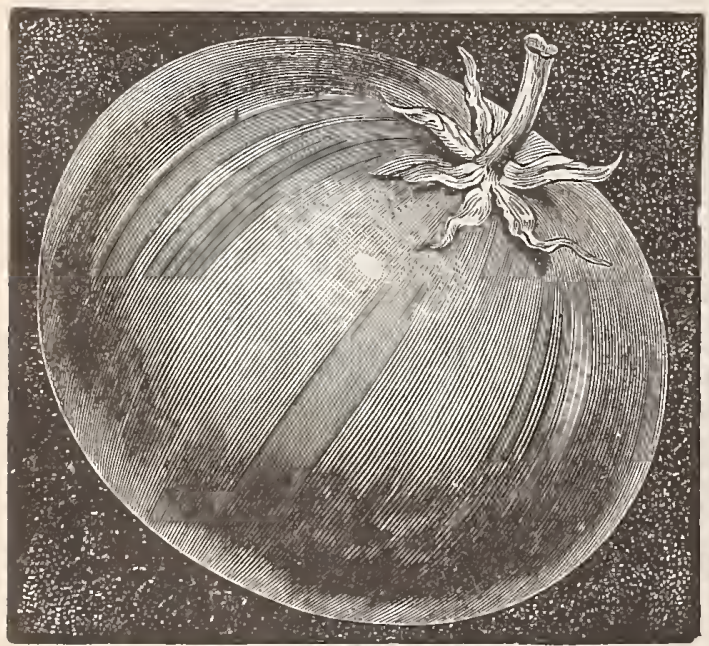

New Tomato, Success.

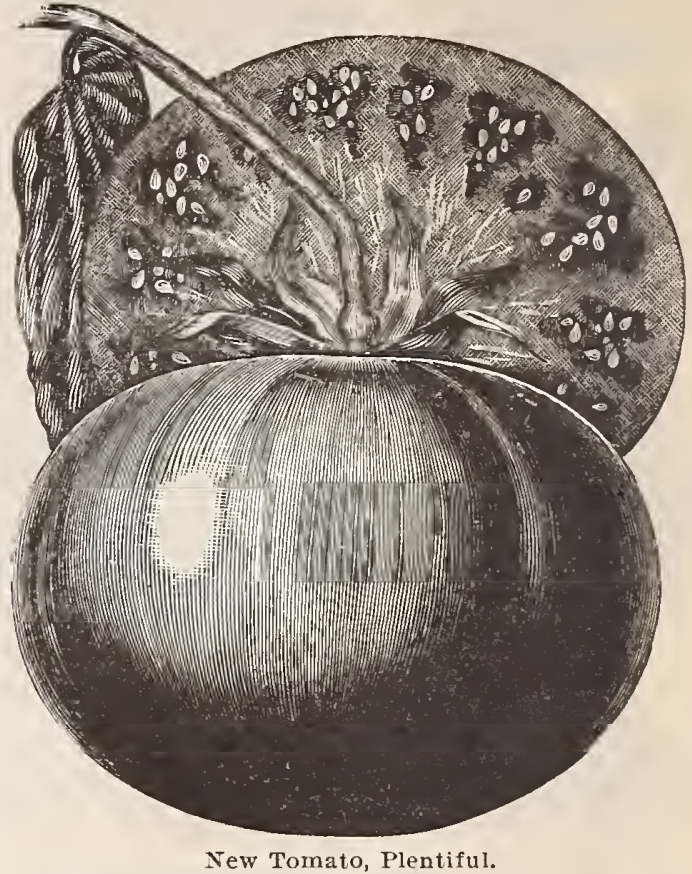

Plentiful. The best main crop tomato ever put on the market. In addition to its very large size, it is also smooth and uniform. The tomatoes are borne in clusters of six to eight immense fruits, and occasionally ten large fruits have been found in single clusters. The color is that pinkish shade so much admired. Pkt. 10c, oz. 20c, 1 oz. 40c, 2 oz. $70 \mathrm{c}$, postage paid.

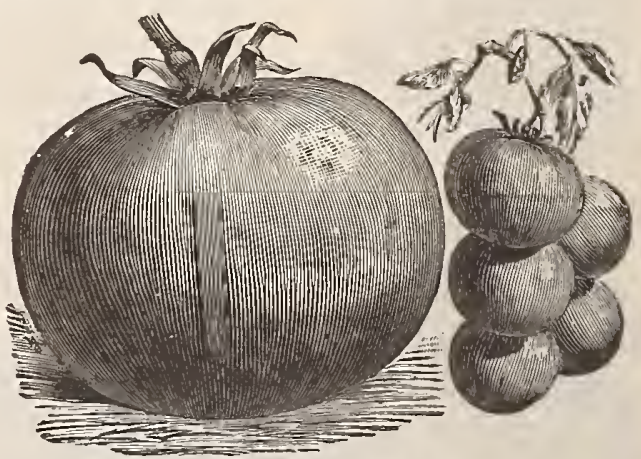

New Tomato, Money Maker.

Money Maker. One of the very best extra early sorts. Five days ahead of Atlantic Prize, and much larger in size. A vigorous grower, productive; fruit smooth, fine rich scarlet in color. Pkt. $10 \mathrm{c}, \frac{1}{2}$ oz. $20 \mathrm{c}$, oz. $40 \mathrm{c}, 2 \mathrm{oz}$. $70 \mathrm{c}$, postage paid.

Emerald, or City Park Lawn Grass Seed is composed exclusively of the very best varieties be best adapted to produce a thick, heavy, carpet-like lawn. Our customers can rely, in buying our Emerald Lawn Grass Seed, on it being the very purest seed obtainable, and entirely free from weeds or foreign seed. For a new lawn, sow four to five bushels to the acre; for renovating, sow two to three bushels to the acre. $\frac{1}{2} \mathrm{lb}$. 20c, lb. 30c, 4 lbs. $\$ 1,14$ lbs. (1 bu.) $\$ 3$. By mail, add 10 c per pound for postage. 


\section{New Aster.}

Lady in White. Produces superb flowers of fine globular shape and of the graceful wavy comet type. In color, they are the purest white, and measure four to five inches in diameter. A very valuable new variety. Pkt. 10c.

American Branching. This vigorous type forms broad, handsome bushes, covered with long stemmed and long petaled flowers that are graceful and feathery in effect. Separate colors, as follows :

Pure white, lavender, flesh pink, purple, crimson.

Price, 10c per pkt ; mixed American Branching Aster, pkt. 5c.

\section{New Candytuft.}

Giant Empress. Of Rocket type, with flowers in upright spikes; very large, pure white. Especially attractive. Pkt. 10c.

\section{New Cosmos.}

Klondyke. A true golden yellow color. Flowers two to three inches wide on graceful stems, and a free bloomer. Pkt. 10c.

IMarguerite. Petals are deeply and irregularly fringed in various bright colors. Pkt. 10c.

IVammoth Perfection. Immense flowers of ten five inches wide. A most desirable class. We have them separate colors or mixed, as desired. White, dark pink, crimson, mixed. Pkt. 10c.

\section{New Pink.}

Plumarius Sweet IVay Pink. These are the fine fragrant perennials of old-time gardens still reckoned among the most beautiful of all pinks for massing and cutting. Pkt. $10 \mathrm{c}$.

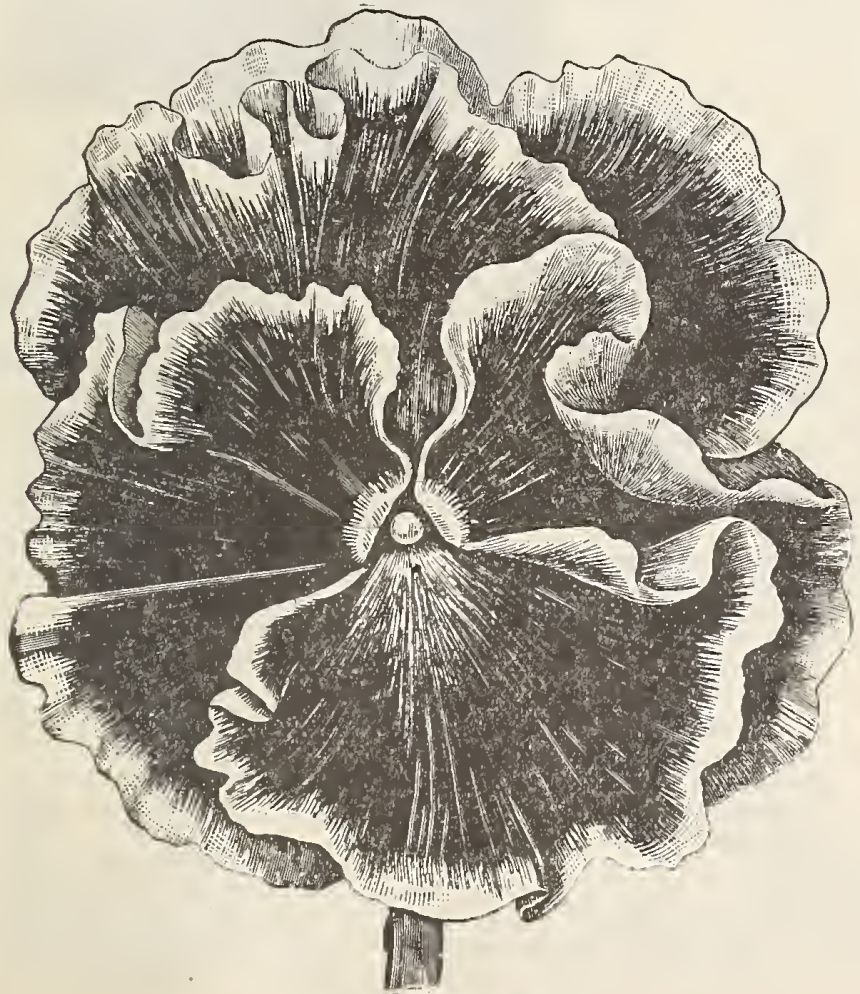

New Pansy, Masterpiece.

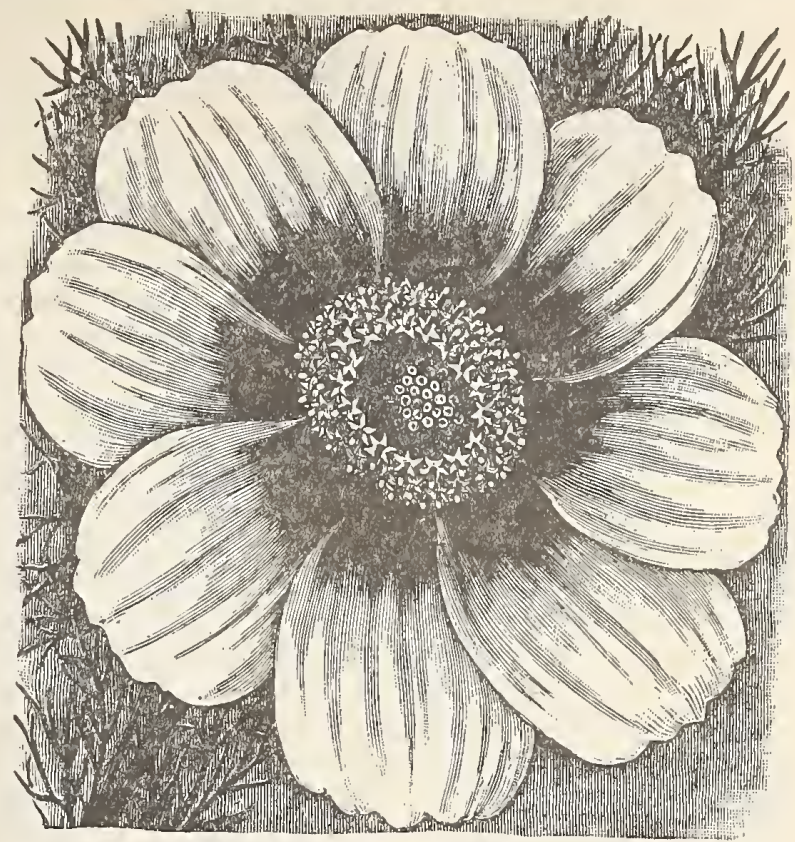

New Cosmos, Mammoth Perfection.

\section{New Petunia.}

California Ruffled Giants. The richest colorings, the largest flowers and the finest marking of all petunias; embracing every conceivable shade of crimson, pink, lavender, pure white and striped. All frilled and ruffled. Pkt. 20c.

\section{New Pansy.}

Masterpiece. A new and distinct variety flower, extra large, and combines every variety of color. Plants vigorous and bloom profusely. Pkt. $15 \mathrm{c}$.

\section{New Poppy.}

Schwill's Superb Mixed. Comprised of the very choicest varieties of single and double poppies. Will make a grand display. Pkt. 5c

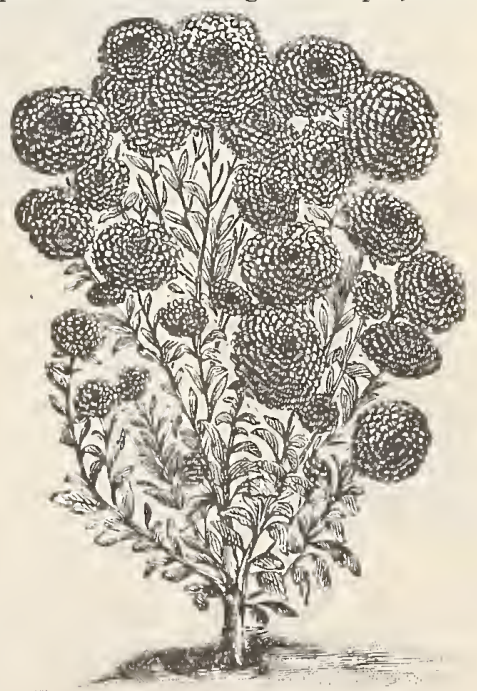

New Aster, American Branching. 


\section{GENERAL LIST OF \\ FLOWER SEEDS.}

GENERAL CULTURAL DIRECTIONS.

$M^{\text {OST flower seeds germinate well in a rather light sandy loam, exposed to the sun, while a few are benefited by }}$

partial shade, and some do best with an element of clay finely mixed with the soil. Nearly all the hardy seeds germinate better when planted in early spring, as soon as the soil can be worked fairly easily.

A general rule for the seed-bed is to have the soil rich, level and worked very finely. Sow the seed evenly in the rows, cover with the finest of soil, about three times the diameter of the seed, and press the soil firmly over the seed. The soil should never become dry after the seeds have swelled, for if it does they will be pretty sure to fail. For this reason it is best to sow most small seeds in shallow boxes, two to three inches in depth, and of any convenient size, that the surface of the soil may be kept properly moistened. After the seeds are up, care must be taken to give them plenty of air and moisture, and yet not too much water, or they will "damp off" (rot at the top of the ground). As soon as the second leaves are well out, they should be transplanted into pots or new boxes. When finally transplanted to the bed or border, they should be watered frequently until well established.

DISCOUNTS.-All purchasers of flower seeds in packets are entitled to liberal discounts, as follows:

For $10 \mathrm{c}$ select any 3 5c pkts. For $25 \mathrm{c}$ select any $85 \mathrm{c}$ pkts. For 50c select any 17 5c pkts.

For $25 \mathrm{c}$ select any $310 \mathrm{c}$ pkts. For $50 \mathrm{c}$ select any $710 \mathrm{c}$ pkts. For $\$ 1$ select any $1510 \mathrm{c}$ pkts.

SIZE OF PACKETS.-Our packets are well filled, so much so that they usually contain sufficient for two or more sowings.

Asters. This has become one of the most popular, beautiful and effective garden plants, growing from 10 to 24 inches high. Sow the seed early in the spring, under glass or in pots in the house, and transplant into rich soil.

Asters-Giant Comet, mixed .............................Packet, 10c

" Dwarf Chrysanthemum, flowered, mixed........ " $10 \mathrm{c}$

" Victoria, finest mixed ........ " 10c

" Pæony, flowered, mixed ............................... " " 10c

" Queen of the Market, mixed

" China, mixed....

"6 All colors, mixed

Adonis-(Pheasant's Eye), mixed.

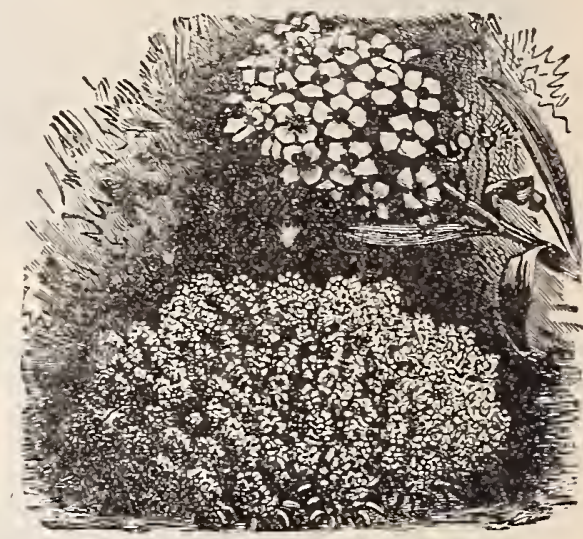

Alyssum, Little Gem.

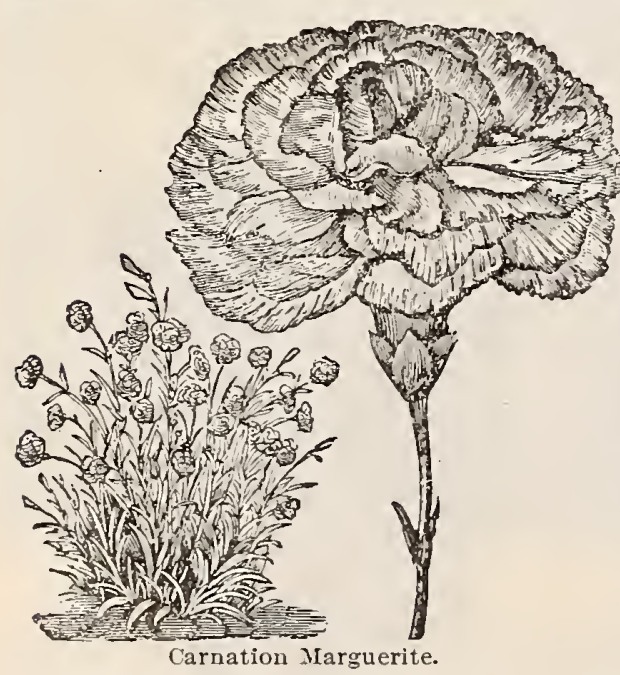

Agrostemma-(Rose of Heaven), mixed.

Packet, כ̃c

Ageratum-Mixed

Alyssum - Sweet

Amaranthustle Gem, dwarf.

" Princess Feather..

Asperula-Mixed

" $5 \mathrm{c}$

Balsam-Touch-Me-Not, double, mixed................ ، $5 \mathrm{c}$

Double Spotted, mixed ........................ " $10 \mathrm{c}$

Browalia-Mixed ..................................... " $5 \mathrm{c}$

Brachycomb-Swan River Daisy, mixed................. " $5 \mathrm{c}$

Candytuft-Giant White Hyacinth, flowered............. " " i0c

Mixed ................................... " $5 \mathrm{c}$

Cannas-Crozy's finest mixed............................. . $5 \mathrm{c}$

Carnation Marguerite-Mixed........................ " $10 \mathrm{c}$

Calendula-(Pot Marigold), mixed ......................... ، $5 \mathrm{c}$

Centranthus-Mixed ................................... " $5 c$

Centaurea Cornflower-Mixed, all shades................... " $5 \mathrm{c}$

Centaurea Cyanus-Imperialis Blue................... " " "c

Centaurea Marguerite-- White .......................... " $10 \mathrm{c}$

Centaurea Candidissima-(Dusty Miller)................ " $5 \mathrm{c}$

Cockscomb-Mixed ....................................... " $5 \mathrm{c}$

Collinsia-Mixed ....................................... " $5 \mathrm{c}$

Selected Nursery Stock. Especial attention is called to the very superior quality of the Nursery Stock ( we supply. It is first - class in every respect - smooth, straight, handsome. Packing and delivery to railroad depot or express office in Memphis free of charge. For light shipments we advise express; larger quantities or heavy packages generally go safely by freight. Purchaser pays transportation charges. State how we shall ship. We will notify you when we make your shipment. 
Calliopsis-Mixed

Columbine-Mixed

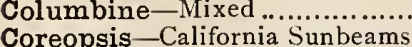

Clarkia-Mixed.

Cosmos-Early Dwarf Dawn

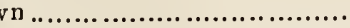

Giant Fancy, mixed

Daisy-Double, mixed..

Dahlia_Double, mixed

Single, mixed.

Forget-Me-Not-Alpertris, mixed

Four O'Clock-(Marvel of Peru), mixed..

Gaillardia-Mixed

Gilia-Mixed

Godetia-Mixed

Gomphrena-Mixed.

Heliotrope-Mixed.

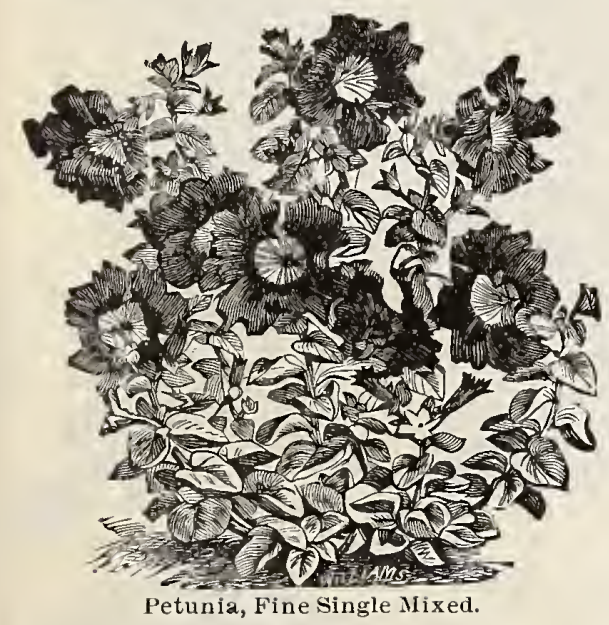

\section{Packet, 5c}

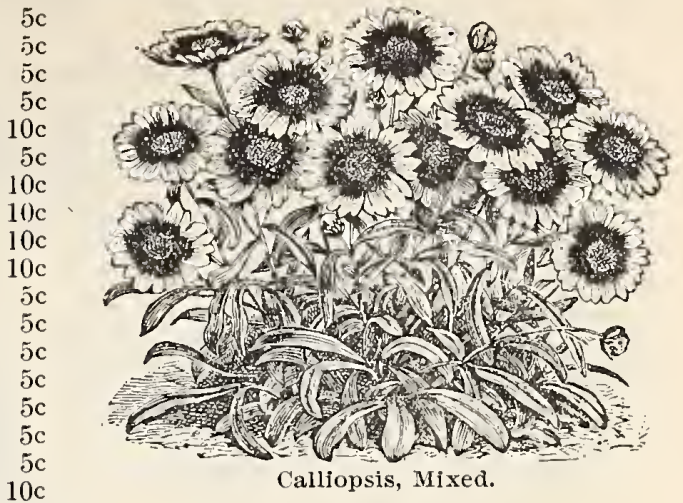

Hollyhock-Double, mixed ...........................Packet, 5c Chater's Superb Double, mixed ............. " $10 \mathrm{c}$

Helichrysum-Mixed................................... ، $5 \mathrm{c}$

Ice Plant............................................... " $5 \mathrm{c}$

Larkspur-Double Dwarf, mixed ......................... ،

Emperor, finest double, nixed ..............

Lobelia-Mixed................ " " 5c

"6 Crystal Palace Gem, dark blue ................. " " $10 \mathrm{c}$

Lupinus-Mixed, all kinds............................ " $5 \mathrm{c}$

Marigold-Double Dwarf, mixed ......................... ، ، $5 \mathrm{c}$

Mignonette-Sweet .................................. ، $5 \mathrm{c}$

" Matchett...................................... " $10 \mathrm{c}$

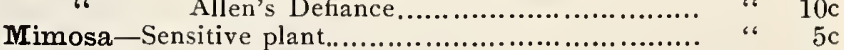

Nemophila_Mixed ....................................... " $5 \mathrm{c}$

Nicotiana-Mixed........................................... ، " $5 \mathrm{c}$

Ornamental Grass-Mixed ........................... ، " $5 \mathrm{c}$

Pansy-Trimardeau Giant, mixed........................... " " 10c

" Extra large flowered, mixed................... " 10

" Snow Queen, pure white ......................... " $10 \mathrm{c}$

" Choice, mixed

Petunia-Striped and Blotched, mixed.................... ، $15 \mathrm{c}$

Defiance Fringed, mixed....................... " $20 \mathrm{c}$

Petunia-Choice Single, mixed

Phlox Drummondii-Choice, mixed

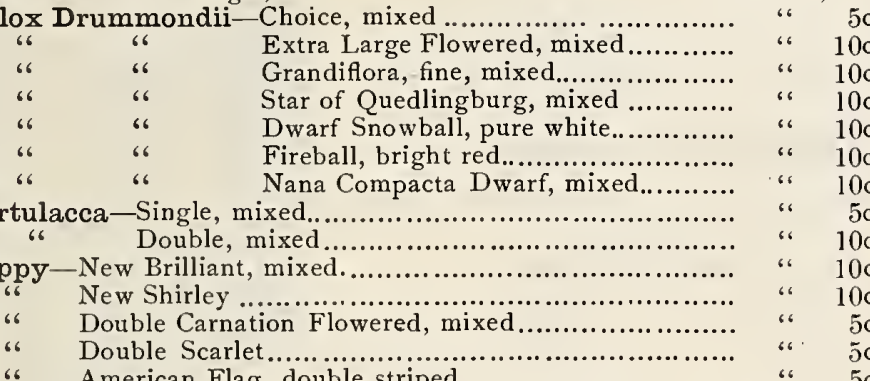

American Flag, double striped .......................... ، $5 c$

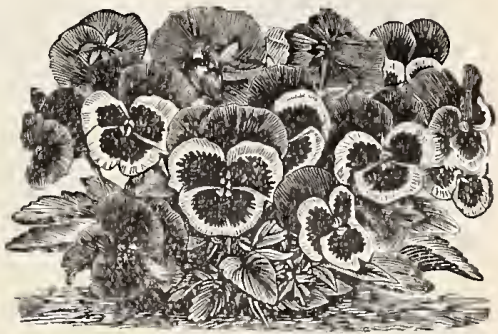

Pansy, Extra Large Mixed.
"6 Mephisto, single fringe, black and red..Pkt., 5c

" $\quad$ Peacock, intense scarlet ..

" Danebrog, single, scarlet and white.....

" Pæony, flowered, wiyed...................

“ Escholtzia, single (c ifornia), mixed..

Pinks-Dianthus China Pine, mixed..

Dianthus Imperialis', imper'l pink, mxd.

Heddewigii Japan Pink, mixed...

Dianthus Double White

Laciniatus Hybrid, mixed....

Dwarf Fireball

Ricinus-Mixed, all shades

t) Zanzibariensis, large.

Salvia-Scarlet Sage

Salpiglossis-Mixed

Snap Dragon-Antirrhinum

Sweet Sultan-Purple...

Sweet William-Single, mixed

Double, mixed
Sweet Rocket-Mixed

Smilax-Myrsiphyllum Asparagoides........... "6 10c

Sunflower-Stella or Star................ " $5 \mathrm{c}$

Stocks-German Ten Weeks................... " " $5 \mathrm{c}$

Verbena-Hybrid, mixed ..................... ، $5 \mathrm{c}$

Extra Large Flowered, mixed .... " " $10 \mathrm{c}$

6 Scarlet Defiance ...................... " 10

، Mammoth White ........................ ، " 10c

، Mammoth Striped ...................... " " $10 \mathrm{c}$

6 Mammoth Mixed, all sliades ....... " $10 \mathrm{c}$

Vinca-Alba Perrywinkle ...................... " " $10 \mathrm{c}$

Rosea Perrywinkle ......................... ، $10 \mathrm{c}$

Mixed Perrywinkle......................... " " $10 \mathrm{c}$

Wallflower--Single, mixed..................... " $5 \mathrm{c}$

Whitlavia-Mixed .............................. " " $5 \mathrm{c}$

Zinnia-Dwarf Mixed .............................. ، " 5c

Dwarf White ......................... " " $10 \mathrm{c}$

Lilliput White Gem ..................... " " $10 \mathrm{c}$

Lilliput Scarlet Gem.................. " $10 \mathrm{c}$ 


\section{Sweet Peas.}

All Seed on this Page 5c per Packet, Three Packets for 10c, Unless Noted Otherwise.

Eckford's Royal Mixture. The finest gilt-edge mixture; containing Eckford's most recent derelopments and very finest varieties of ercry shade and color. Try these and learn of the improved large flowering Sweet Pea. Pkt. $\check{c}$,

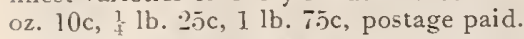

Schwill's Superb Mixed. The finest large flowering variety. Pkt. 5c, oz. 10c, 2 oz. 15c, 1 1b. $20 \mathrm{c}, 2 \mathrm{l}$ lb. $30 \mathrm{c}, 1 \mathrm{lb} .60 \mathrm{c}$, postage paid.

Choice Mixed. Oz. 5 c, ${ }_{11}^{1} 1 \mathrm{~b}$. $15 \mathrm{c}, 1 \mathrm{lb}$. 50c, postage paid.

Cupid Mixed. Pkt. 5c, oz. 10c, „2 oz. 20c, ${ }_{4}^{\frac{1}{4}} \mathrm{lb} . \$ 35 \mathrm{c}, 1 \mathrm{lb} . \$ 1.00$, postage paid.

\section{Named Sweet Peas in Separate Colors.}

Price, any variety, plt. 5c, oz. 10c, 2) oz. 20c, $1 \mathrm{lb} .25 \mathrm{c}, 1 \mathrm{lb} .75 \mathrm{c}$, postage paid.

\section{PIRE WHITE.}

Blanche Burpee.

Sadie Burpee.

Emily Henderson. Mont Blanc.

\section{Prima Donna. \\ Royal Robe. \\ Katherine Tracy. \\ Blanche Ferry. Modesty. Lovely.} PINK.

HoSF.

Her Majesty. Mrs. Dugtale. Prince Edward of York. Prince of Wales.

YAROON ANI BLCE.

Black Knight.

Shadaza.

Othello.

Duke of Westminster. Navy Blue.

YELLOW.

Mrs. Eckford. Queen Victoria.

SHADES OF LAVENDER.

Countess of Radnor.

Emily Eckford.

Dorothy Tennant.

Captivation.

Gray Friar.

Lady Grisel Hamilton.

Lottie Eckford.

Maid of Honor.

Countess of Cadogan.

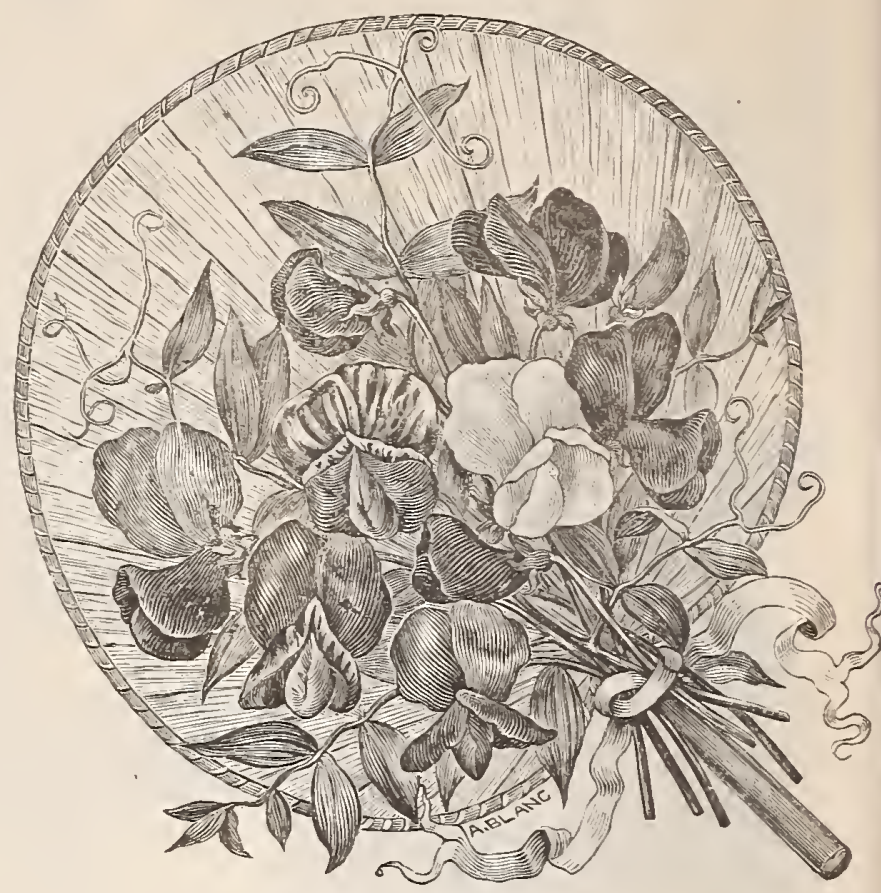

Sweet Peas, Eckford's Royal Mixed.

PINK IND RED SHADES.

Aurora.

Sensation.

Hon. F. Bouverie.

Lady Skelmersdale.
Lady May Curry. Stella Morse.

Coquette.

Eliza Eckford.

America.

\section{Cupid Sweet Peas.}

White Cupid. Packet .jc, ounce 10c, ti pound 30c.

Pink Cupid. Packet 5c, ounce. 10c, 1 pound 50c.

\section{New Sweet Peas.}

Majestic. A most beautiful rosy color; deeper than Her Majesty; very large form and of delightful fragrance. Pkt. 5c, oz. 25c. 2) oz. 40c.
Earliest of All. This is one of the latest additions and is identical with Blanche Ferry, except that it is nore dwarf and comes into bloom ten days earlier. Pkt. 5c, oz. $15 \mathrm{c}, 2 \mathrm{oz} .25 \mathrm{c}, \frac{7}{4}$ lb. $40 \mathrm{c}$, postage paid.

\section{Vines and Climbers.}

Balsam Apple --Balsamina..................... Pkt. 5c

Balsam Pear-Charantia...................... " jc

Balloon Vine-Love in a Puff................. " " $5 \mathrm{c}$

Cypress Vine-Mixed.......................... ، " $5 c$

Climbing Hop Humulus Japonicus.......... " "

Cobea Scandens-Blue _o jc

Canary Bird Flower............................ ", "s

Gourds-Ornamental, mixed.

" Orange Shaped

" Hercules Club

" Dipper.

“ Nest Egg

" Sugar Trough

" Dish Rag Lufia
Hyacinth Climbing E:an...

Moon Vine-Impomea Grandiflora............. ، $10 \mathrm{c}$

Morning Glory-Mixed....................... " " jc "6 6 Brazilian Impomea Setora... .. $10 \mathrm{c}$

Japanese Imperial............ $\because \frac{}{4} \quad 5 c$

Scarlet Runner...............................

Thunbergia - Black-Eyed Sue ................. " 5c

Nasturtium-Tall, mixed, all shades...oz. 15c, 2 oz. $25 \mathrm{c}, \frac{3}{4} \mathrm{lb} .40 \mathrm{c} \ldots \ldots \ldots \ldots \ldots \ldots \ldots \ldots \ldots$ o $5 \mathrm{c}$

Nasturtium-Dwarf, mixed, all shades.....

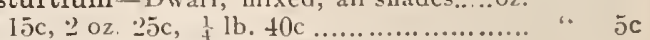

Nasturtium-Madam Gunther's Hybrid Climbing, mixed, all shades.... \% . 15c, 2 oz, 25c. " 5c 


\section{General
List of. Vegetable Seeds}

I has ever been our endeavor as Seedsmen to make HIGHEST QUALITY the first consideration, and then to fix our prices as low as GOOD, RELIABLE SEEDS can be sold. It is the poorest economy for the planter to invest in seeds whose chief recommendation is that they are cheap Our prices include postage on packets, ounces, quarter pounds, pounds, pints and quarts, except where noted. If the purchaser will pay the freight or express charges, ten cents per pound, fifteen cents per quart and ten cents per pint may be deducted from the prepaid prices herein offered.

Discount on.... From catalogue prices by the quarter pound, pound, peck or bushel, Seeds in Bulk when cash is sent with order, purchaser may deduct five per cent. on Seeds in BulK an order from $\$ 5.00$ to $\$ 10.00$, and ten per cent. on an order from $\$ 10.00$ to $\$ 20.00$. This discount refers to seeds quoted in catalogue by weight or measure (except those in the division of Farm Seeds), and not to Potatoes or Bulbs, nor to seeds in

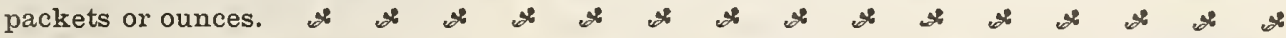

\section{Half Ounce, Ounce and Two Ounce Seed Discounts.}

Purchasers may make selections of seeds in half ounces, ounces and two ounces at these discounts: For $25 \mathrm{c}$ select seeds in half, one and two ounce packages, amounting to.................\$ .30 For $50 \mathrm{c}$ select seeds in half, one and two ounce packages, amounting to...........................65 For $\$ 1.00$ select seeds in half, one and two ounce packages, amounting to ................ 1.30 For $\$ 2.00$ select seeds in half, one and two ounce packages, amounting to ..................... 2.70 For $\$ 3.00$ select seeds in half, one and two ounce packages, amounting to ................ 4.00

All Vegetable Seeds priced 5c per pkt. are sold 3 pkts. for 10c, postpaid, without any further discount.

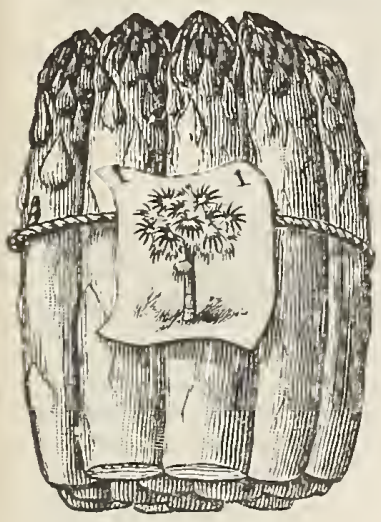

Palmetto Asparagus.
Large Packets. - Customers write that our packets are well filled, and contain more seeds than others.

\section{ASPARAGUS.}

The soil for Asparagus can hardly be made too rich, and the manure should be well trenched in, to the depth of two feet or more. The roots should be planted as early in spring as the ground can be prepared, setting them a foot apart in rows three or four feet apart, with the crowns from four to six inches below the surface of the bed.

\section{ASPARAGUS ROOTS.}

Our own raising; sure to grow; fine, large crowns. Palmetto. Two years old. Per $100 \$ 1$, per $1000 \$ 6$. Colossal. Two years old. Per $10075 \mathrm{c}$, per $1000 \$ 5$.

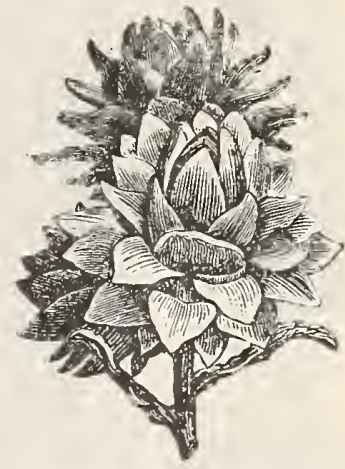

Green Globe Articboke.

\section{ASPARAGUS SEED.}

Price 5 cents per packet, any variety

Palmetto. Earlier than Colosșal, with stalks as fine in size and quality, and more eren and regular in growth. Oz. $10 \mathrm{c}, 2$ oz. $20 \mathrm{c}, \frac{1}{4} \mathrm{lb} .30 \mathrm{c}, 1 \mathrm{~b} . \$ 1.00$, postpaid.

Conover's Colossal. Very large, deep green, tender. Oz. 10c, 2- oz. 15c, 산 lb. 20c, lb. $65 \mathrm{c}$.

Columbian Mammoth White. Stalks are large, clear white. Oz. 10c, 2 oz. 20c, $\frac{1}{4}$ lb. $30 \mathrm{c}, 1 \mathrm{~b} . \$ 1.00$.

\section{BRUSSELS SPROUTS.}

The plant grows two or three feet high, and produces from the sides of the stalk numerous little sprouts one or two inches in diameter, resembling cabbage.

Improved Dwarf. Packet 5 cents, ounce 25 cents.

\section{ARTICHOKES.}

Culture: Sow seed of French Artichokes in spring in rich, light, loamy soil, and in drills about ten inches apart. Transplant next spring in permanent rows four feet apart.

Green Globe French. The very best variety; buds are large, thick and fleshy. Packet 5c, oz, 30c, $20 \mathrm{oz} 50 \mathrm{c}$, $\Varangle$ pound $\$ 1.00$, postage paid.

Globe Plants. Our own raising; will produce a crop the first season. Each $20 \mathrm{c}$, doz. $\$ 2.00$, by express only:

Jerusalem. For hogs. See index for page.

\section{BROCOLI.}

Culture: Sow as soon as the ground can be worked in the spring. Plant out two feet apart each way.

Purple Cape. Best for this country. Pkt. jc, oz. 40c. 


\section{Bush, Dwarf or Snap Beans.}

One quart to 100 feet drill; $1 \frac{1}{2}$ bushels to the acre in drills. Plant when all danger of frost is over. Drop the Beans two or three inches apart in rows standing eighteen inches to two feet apart. Hoe often-never when the vines are wet, or they will rust, drawing the earth slightly toward them, and at least once before they blossom sow land plaster upon them. As they require but six to eight weeks to make green pods, they can be sown as late as September 1 .

\section{DWARF GREEN POD VARIETIES.}

Burpee's Stringless Green Pod. Extreme earliness and extra good quality are the two points which we desire to emphasize in connection with this promising Bean. A quick grower, being ready for market in advance of the old Valentine. The pods are full and fleshy and entirely stringless. $\frac{7}{3}$ pt. $10 \mathrm{c}, \frac{1}{2} \mathrm{pt} .15 \mathrm{c}, \mathrm{pt} .25 \mathrm{c}, \mathrm{qt} .40 \mathrm{c}$, postpaid. By express or freight: $\frac{1}{2}$ pk. $75 \mathrm{c}, \mathrm{pk} . \$ 1.25$, bu. $\$ 4.50$.

Improved Early Red Valentine. Productive; round, fleshy pods, brittle and tender. The best for main crop for market gardener or general family use. $\frac{1}{3}$ pt. $10 \mathrm{c}$, 1 pt. $15 \mathrm{c}, \mathrm{pt} .25 \mathrm{c}$, qt. $40 \mathrm{c}$, postpaid. By express or freight : $\frac{1}{2}$ pk. $75 \mathrm{c}, \mathrm{pk} . \$ 1.25$, bu. $\$ 4.50$.

Early Mohawk. Long, flat and straight pods; very hardy. $\frac{1}{9}$ pt. $10 \mathrm{c}, \frac{1}{2}$ pt. $15 \mathrm{c}$, pt. $25 \mathrm{c}$, qt. $40 \mathrm{c}$, postage paid. By express or freight : $\frac{1}{2} \mathrm{pk} .75 \mathrm{c}$, pk. $\$ 1.25$, bu. $\$ 4.50$.

Early Yellow Six Weeks. Early ; the leading market sort; full, flat, green pods; good quality. $\frac{1}{3}$ pt. $10 \mathrm{c}$, $\frac{1}{2}$ pt. $15 \mathrm{c}, \mathrm{pt} .25 \mathrm{c}$, qt. $40 \mathrm{c}$, postage paid. By express, 1 pk. $75 \mathrm{c}$, pk. $\$ 1.25$, bu. $\$ 4.25$.

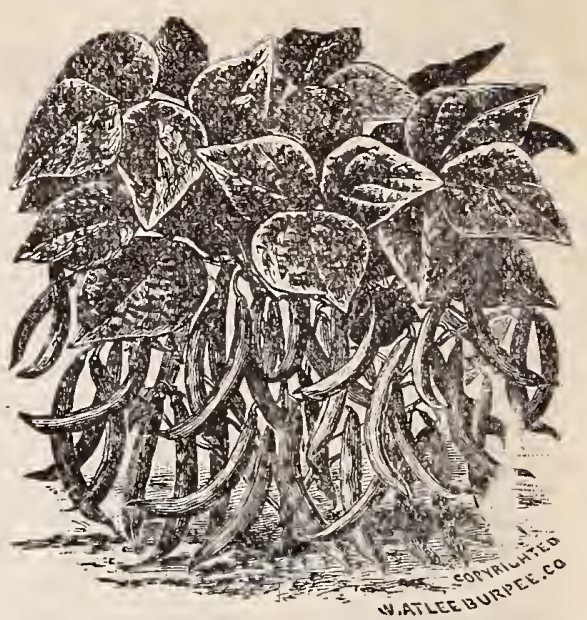

Burpee's Stringless Green Pod Bush Beans.

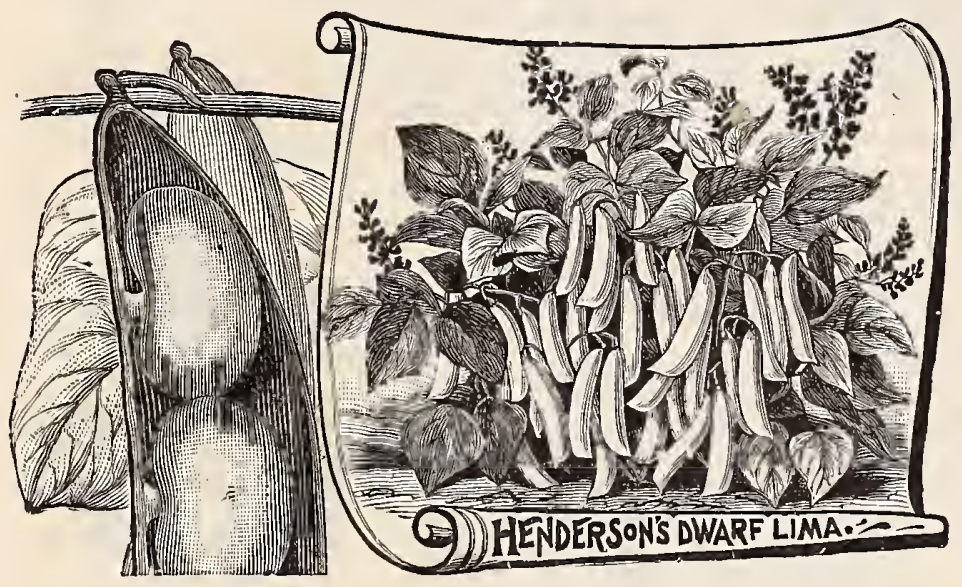

White Valentine. Round pods, fleshy and of splendid flavor. $\frac{1}{3}$ pint $10 \mathrm{c}$, $\frac{1}{\frac{1}{3}}$ pint $15 \mathrm{c}$, pint $25 \mathrm{c}$, quart $45 \mathrm{c}$, postage paid. By express or freight, $\frac{1}{2}$ peck $75 \mathrm{c}$, peck $\$ 1.25$, bushel $\$ 4.25$.

Best of All. Early and superior; round, green, fleshy pods. $\frac{1}{3} \mathrm{pt} .10 \mathrm{c}$, $\frac{1}{2}$ pt. $35 \mathrm{c}, \mathrm{pt} .25 \mathrm{c}, \mathrm{qt} .40 \mathrm{c}$, postpaid. By express, $\frac{1}{2} \mathrm{pk} .75 \mathrm{c}$, pk. $\$ 1.25$, bu. $\$ 4.25$.

Wood's Prolific Bush Lima. A most productive Bush Lima variety. Bean - some larger than Henderson's Bush Lima. $\frac{1}{3}$ pt. $15 \mathrm{c}, \frac{1}{2}$ pt. $20 \mathrm{c}$, pt. $30 \mathrm{c}$, qt. $60 \mathrm{c}$, postage paid. By express, $\frac{1}{2} \mathrm{pk} . \$ 1.00, \mathrm{pk} . \$ 1.75$, bu. $\$ 6.50$.

Large White Marrow Beans. $\frac{1}{3}$ pt. $10 \mathrm{c}, \frac{1}{2}$ pt. $15 \mathrm{c}$, pt. $20 \mathrm{c}$, qt. $35 \mathrm{c}$, postpaid. By express, 1 pk. $50 \mathrm{c}$, bu. $\$ 3.50$.

Prolific Tree Beans. $\frac{1}{3}$ pt. $10 \mathrm{c}, \frac{1}{2}$ pt. $15 \mathrm{c}$, pt. $20 \mathrm{c}$, qt. $35 \mathrm{c}$, postage paid. By express, $\frac{1}{2} \mathrm{pk}$. 50c, bu. $\$ 3.50$.

Jackson's Wonder Bush Lima. Stands the hot, dry summers. Beans are of splendid flavor and immensely productive. $\frac{1}{3} \mathrm{pt}$. 11)c, $\frac{1}{2} \mathrm{pt} .15 \mathrm{c}, \mathrm{pt}$. $25 \mathrm{c}$, qt. 40c, postage paid. By express, $\frac{1}{2}$ pk. $\$ 1.00$, pk. $\$ 1.50$, bu. $\$ 5.00$.

Henderson's Dwarf or Bush Lima. Grows in compact bush form and produces large crops. $\frac{1}{3} \mathrm{pt} .10 \mathrm{c}$, $\frac{1}{2}$ pt. $15 \mathrm{c}$, pt. $25 \mathrm{c}$, qt. $50 \mathrm{c}$, postage paid. By express, $\frac{1}{2}$ pk. $\$ 1.00$, pk. $\$ 1.75$, bu. $\$ 7$.

\section{DWARF WAX VARIETIES}

German or Black Wax. Very early and prolific. The pods are round, full, stringless and of fine quality. $\frac{1}{3} \mathrm{pt} .10 \mathrm{c}, \frac{1}{2} \mathrm{pt} .15 \mathrm{c}, \mathrm{pt} .25 \mathrm{c}$, qt. $45 \mathrm{c}$, postage paid; by express, $\frac{1}{2} \mathrm{pk} . \$ 1, \mathrm{pk} . \$ 1.75$, bu. $\$ 6.50$.

Currie's Rust-Proof Wax. Flat pods; very early and productive. $\frac{1}{\mathrm{~s}}$ pt. $10 \mathrm{c}, \frac{1}{2} \mathrm{pt} .15 \mathrm{c}$, pt. $25 \mathrm{c}$, qt. $45 \mathrm{c}$, postage paid; by express, $\frac{1}{2}$ pk. $\$ 1$, pk. $\$ 1.75$, bu. $\$ 6.50$.

Flageolet Crimson Wax. Fine shipper; pods very large, ten to twelve inches in length; entirely stringless. $\frac{1}{3} \mathrm{pt} .10 \mathrm{c}, \frac{1}{2} \mathrm{pt} .15 \mathrm{c}, \mathrm{pt}$. $25 \mathrm{c}$, qt. 40c, postpaid; by express, $\frac{1}{2}$ pk. $75 \mathrm{c}, \mathrm{pk}$. $\$ 1.50$, bu. $\$ 5.50$.

Valentine Wax. A new, distinct variety; very handsome; golden yellow pods, very tender and of fine flavor. $\frac{1}{s} \mathrm{pt} .10 \mathrm{c}, \frac{1}{2} \mathrm{pt} .15 \mathrm{c}, \mathrm{pt}$. $25 \mathrm{c}$, qt. 35c, postpaid; by express, $\frac{1}{2} \mathrm{pk}$. $75 \mathrm{c}, \mathrm{pk} . \$ 1.50$, bu. $\$ 5.50$

Pint and quart prices include postage. If to go by express at buyer's expense, deduct $15 \mathrm{c}$ from quart, or $10 \mathrm{c}$ from pint prices.
Thorburn's Bush Lima. A dwarf form of the famChallenger Lima; very productive. $\frac{1}{3} \mathrm{pt} .15 \mathrm{c}, \frac{1}{2} \mathrm{pt}$ $20 \mathrm{c}$, pt. 30c, qt. 50c, postage paid. By express, $\frac{1}{2} \mathrm{pk}$. $\$ 1.00$, pk. $\$ 1.75$, bu. $\$ 6.50$.

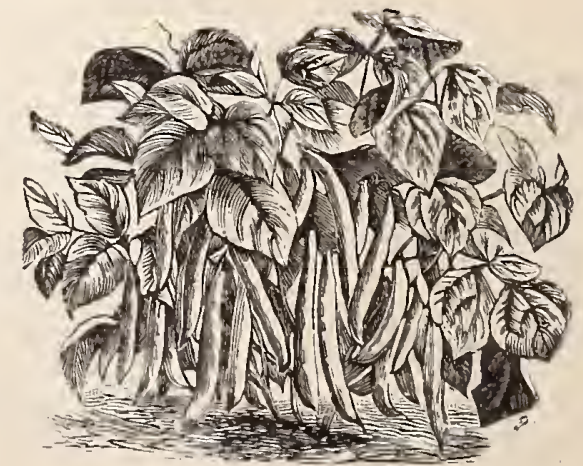

Best of All. 
DWARF WAX VARIETIES-Continued.

Improved Dwarf Golden Wax. Very early; round, golden pods. $\frac{1}{3}$ pt. $10 \mathrm{c}, \frac{1}{2} \mathrm{pt} .15 \mathrm{c}$, pt. $25 \mathrm{c}$, qt. $45 \mathrm{c}$, postage paid; by express, $\frac{1}{2}$ pk. $\$ 1.00$, pk. $\$ 1.75$, bu. $\$ 6.50$.

Refugee Wax. A perfect refugee, with long, round wax pods. An immense yielder. $\frac{1}{3}$ pt. $10 \mathrm{c}, \frac{1}{2}$ pt. $15 \mathrm{c}, \mathrm{pt}$. $25 \mathrm{c}$, qt. $45 \mathrm{c}$, postage paid. By express, $\frac{1}{2}$ pk. $\$ 1.00$, pk. $\$ 1.75$, bu. $\$ 6.50$.

Yosemite Mammoth Wax. Pods very large and fleshy, and entirely stringless, tender and of the finest quality. $\frac{1}{3} \mathrm{pt} .15 \mathrm{c}, \frac{1}{2} \mathrm{pt}$. $20 \mathrm{c}$, pt. 30c, qt. 50c, postage paid; by express, $\frac{1}{2}$ peck $\$ 1.00$, peck $\$ 1.75$, bushel $\$ 6.50$.

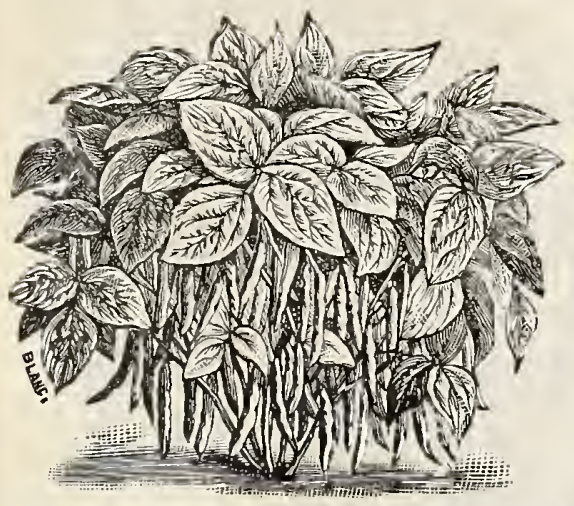

Improved Dwarf Golden Wax Bush Bean.
Garden Making. By L. H. Bailey. In this book the beginner in gardening is shown how easy it is to raise flowers, vegetables and fruits. It is thoroughly practical in every detail, and as a guide to daily practice in the garden, it has no equal in horticultural literature.

Cloth, 12mo., $\$ 1$.

\section{Lima and Butter Beans.}

Siebert's Early Lima. The earliest true Lima and the very best for market gardeners; rich in flavor. $\frac{1}{3} \mathrm{pt} .10 \mathrm{c}, \frac{1}{2} \mathrm{pt} .15 \mathrm{c}$; pt. 25 c, qt. 45 c, postpaid; by express, $\frac{1}{2}$ pk. $\$ 1.00$, pk. $\$ 1.50$, bu. $\$ 5.50$.

King of the Garden Lima. A vigorous grower, bearing profusely large pods. The beans are large and of rich flavor. $\frac{1}{3} \mathrm{pt}$. $10 \mathrm{c}, \frac{1}{2}$ pt. $15 \mathrm{c}$, pt. $25 \mathrm{c}$, qt. $45 \mathrm{c}$, postage paid. By express, $\frac{1}{2} \mathrm{pk}$. 75 c, peck $\$ 1.50$, bushel $\$ 5.50$.

Large White Lima. A splendid variety; very large pods, measuring five to eight inches, filled with delicious, extra size beans. $\frac{1}{3}$ pt. $10 \mathrm{c}$, $\frac{1}{2}$ pt. $15 \mathrm{c}$, pint $25 \mathrm{c}$, quart $45 \mathrm{c}$, postage paid; by express, $\frac{1}{2}$ peck $75 \mathrm{c}$, peck $\$ 1.50$, bushel $\$ 5.50$.

Willow Leaf Lima. One of the most productive sorts; hardy and vigorous grower; just the variety for the South. $\frac{1}{3}$ pint $10 \mathrm{c}$, $\frac{1}{2}$ pt. $15 \mathrm{c}$, pt. $25 \mathrm{c}$, qt. $45 \mathrm{c}$, postage paid; by express, $\frac{3}{2}$ peck $\$ 1.00$, peck $\$ 1.75$, bushel $\$ 6.00$.

Carolina or Small Lima Butter Bean. Smaller leaves and seeds, but earlier and more hardy than the Large Lima, and far more prolific. $\frac{1}{8}$ pt. $10 \mathrm{c}$, $\frac{1}{2}$ pt. $15 \mathrm{c}$, pt. $25 \mathrm{c}$, qt. $45 \mathrm{c}$, postage paid; by express, $\frac{1}{2}$ pk. $\$ 1.00$, pk. $\$ 1.75$, bu. $\$ 6.00$.

\section{LAND PLASTER.}

A supply of Land Plaster should always be kept on hand by every farmer. The well-known benefit derived from the application of this as a top dressing for Grass and Clover in the spring should make it universally used for this purpose. It is most useful as an insecticide, and to use when planting Potatoes, and also to use in stables, cattle stalls, chicken houses, on manure piles, etc. It will add very largely to the manure value of the farm if it is freely used, as it prevents the escape of ammonia, at the same time stopping foul odors and adding to the cleanly appearance of stables, etc., where used. As a top dressing for Grass and Clover crops, it should be applied at the rate of 200 to $300 \mathrm{lbs}$. per acre the first open growing weather in spring. Per bag of $200 \mathrm{lbs}$., $\$ 1.25$; per ton, $\$ 10$.

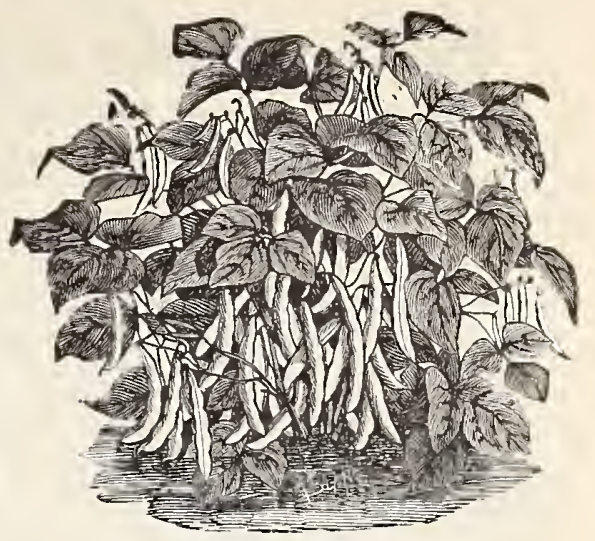

Yosemite Mammoth Wax Bean.

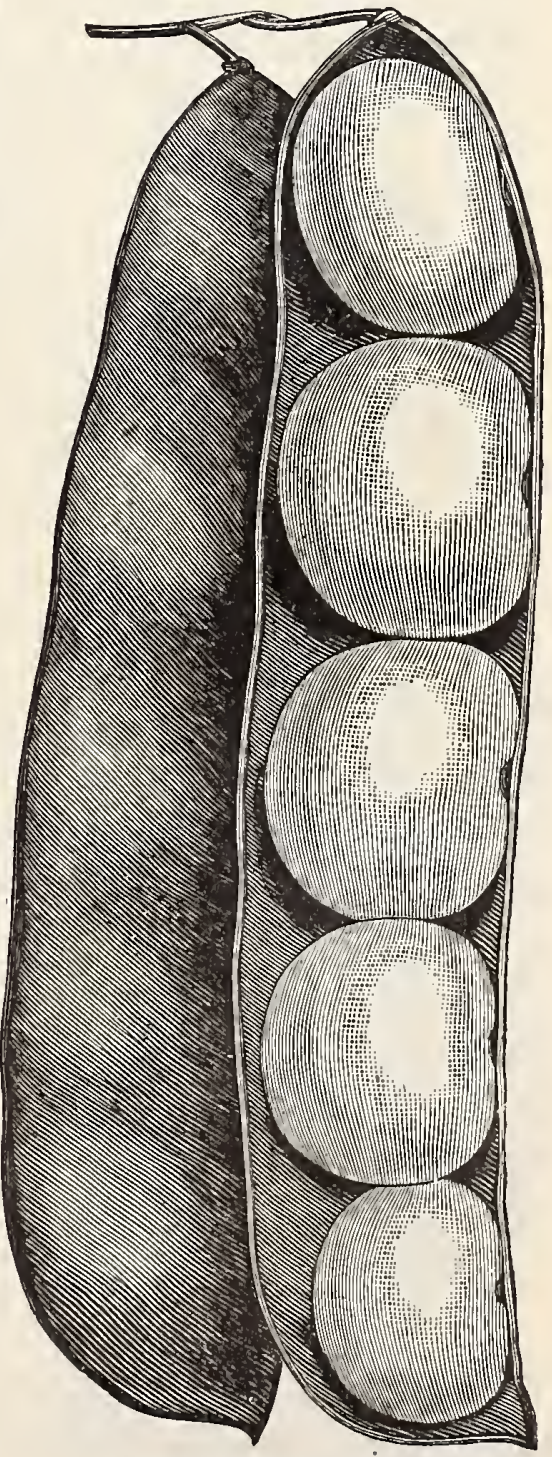

Siebert's Early Lima Bean. 


\section{Pole or Running Beans.}

One Quart will Plant about 150 Hills.

These require more care than the Bush Beans, and should not be planted until two weeks later, as they stand in much more danger from the frosts. Plant in hills, from five to six seeds in each, about two inches deep; the hills should be four feet apart.

Kentucky Wonder, or Old Homestead. One of the best green podded Pole Beans, being extremely early, and is enormously productive, the pods hanging in great clusters from top to bottom of pole. It is entirely stringless, and the pods are of a silvery green color, and cook tender and melting. $\frac{1}{3} \mathrm{pt} .10 \mathrm{c}$, $\frac{1}{2}$ pt. $15 \mathrm{c}$, pt. $25 \mathrm{c}$, qt. $45 \mathrm{c}$, postage paid; by express, $\frac{1}{2} \mathrm{pk} .75 \mathrm{c}$, peck $\$ 1.50$, bushel $\$ 5.75$.

Lazy Wife's Pole Bean. Pods of medium dark green color, broad, thick and very fleshy, and retain their rich, tender qualities until nearly ripe. $\frac{1}{3}$ pt. $10 \mathrm{c}, \frac{1}{2}$ pt. $15 \mathrm{c}$, pint $25 \mathrm{c}$, quart $50 \mathrm{c}$, postpaid; by express, $\frac{1}{2}$ pk. $\$ 1.00$, pk. $\$ 1.75$, bu. $\$ 6.00$.

Southern Creaseback. Perfectly round, with a crease in the back; very fleshy and of fine quality. $\frac{1}{3}$ pt. $10 \mathrm{c}, \frac{1}{2} \mathrm{pt} .15 \mathrm{c}$, pint $25 \mathrm{c}$, quart $45 \mathrm{c}$, postage paid; by express, $\frac{1}{2}$ peck $75 \mathrm{c}$, peck $\$ 1.50$, bushel $\$ 5.50$.

Southern Prolific. A continuous bearer of good quality. pt. 10c, $\frac{1}{2}$ pt. 15c, pt. $25 \mathrm{c}$, qt. 45c. postage paid; by express, pk. $75 \mathrm{c}, \mathrm{pk}$. $\$ 1.25$, bu. $\$ 4.75$.

Red Speckled, Cut Short, or Corn Hill. Used for plant-

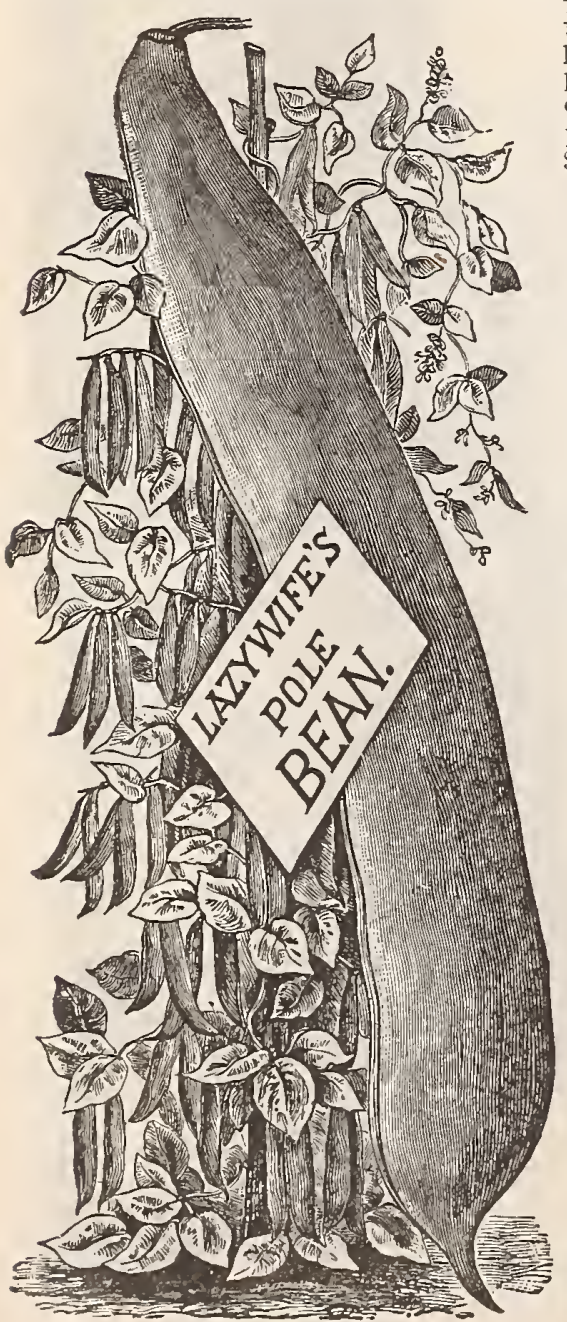
ing a mong corn. $\frac{1}{3}$ pt. $10 \mathrm{c}, \frac{1}{2}$ pt. $15 \mathrm{c}$ pt. $25 \mathrm{c}$, quart $45 \mathrm{c}$, postage $\mathrm{p}$ a id; by express, $\frac{2}{3}$ pk. $75 \mathrm{c}$, peck $\$ 1.50$, bushel $\$ 5.50$.

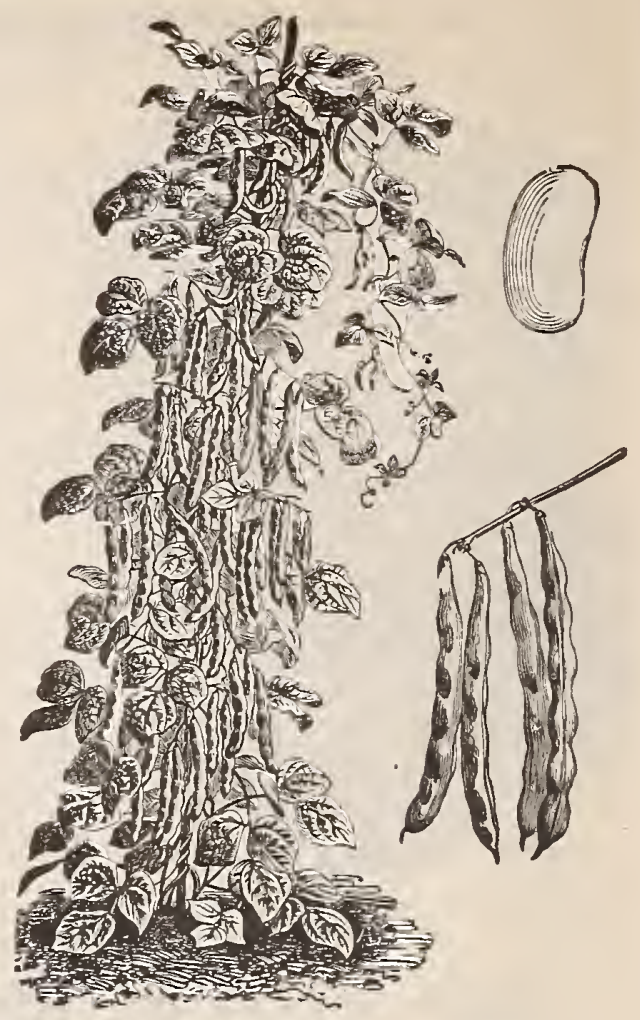

Kentucks Wonder, or Old Homestead.

Horticultural, or Wren's Egg. Good as a Snap or Shell Bean. $\frac{T}{3} \mathrm{pt}$. 10c, $\frac{1}{2} \mathrm{pt}$. $15 \mathrm{c}$, pt. $25 \mathrm{c}$, qt. $40 \mathrm{c}$, postage paid; by express, $\frac{1}{2}$ pk. $75 \mathrm{c}, \mathrm{pk}$. $\$ 1.25$, bu. $\$ 4.50$.

Golden Cluster Wax. Beautiful golden wax color, of large size, and always tender and brittle, being entirely stringless; very early and productive. $\frac{1}{3}$ pt. $10 \mathrm{c}, \frac{1}{2} \mathrm{pt} .15 \mathrm{c}$, pt. $30 \mathrm{c}$, qt. $50 \mathrm{c}$, postage paid; by express, $2 \mathrm{pk} . \$ 1.00, \mathrm{pk} . \$ 1.75$, bu. $\$ 6.00$.

Golden Andulasia. Round, fleshy pods, golden wax in color, and is entirely stringless. $\frac{1}{3}$ pint $10 \mathrm{c}, \frac{1}{2}$ pint $15 \mathrm{c}$, pint $30 \mathrm{c}$, quart $50 \mathrm{c}$, postage paid ; by express, 2 peck $\$ 1.00$, peck $\$ 1.75$, bushel $\$ 6.00$.

All those who pass through the Door of Success find it labeled "Push."

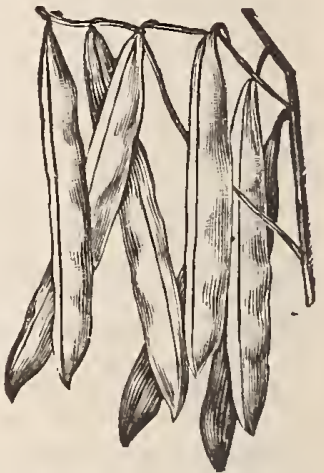

Southern Creaseback.

\section{Schwill's Kitchen Garden Collection.}

\section{PRICE, SIXTY CENTS.}

Sent postage paid to any address upon receipt of price. At regular prices this would cost you $\$ 1.00$. No change allowed in this collection. $\frac{1}{3}$ pt. Peas, Extra Early Alaska. 1 pkt. Parsnip, Sug. Hollow Crown $\frac{1}{3}$ pt. Peas, Lg. Wh. Marrowfat. 1 pkt. Mustard, Sou. Giant Curled $\frac{1}{3}$ pt. Bunch Beans, Inp. Val. 1 pkt. Radish, Early Scarlet Turnip $\frac{1}{3}$ pt. Pole Beans, Ky. Wonder. 1 pkt. Radish, Early Long Scarlet 1 pkt. Beet, Early Blood Turnip. I pkt. Squash, Early White Bush 1 pkt. Cabbage, Early Flat Dutch. 1 pkt. Spinach, Curled Savoy 1 pkt. Cucumber, White Spine 1 pkt. Turnip, Purple Top, S. L. 1 pkt. Carrot, Imp. Long Orange, 1 pkt. Tomato, Acme Early 1 pkt. Collard, Georgia.

1 pkt. Lettuce, White Cab. Head 


\section{Garden and Sweet Corn.}

\section{FOR TABLE USE.}

One quart will plant 200 hills, one peck will plant an acre in hills. Plant as soon as the ground becomes warm in the spring, in hills about three feet apart, five or six grains to the hill, and when up thin them out. For a succession, plant every two weeks until midsummer.

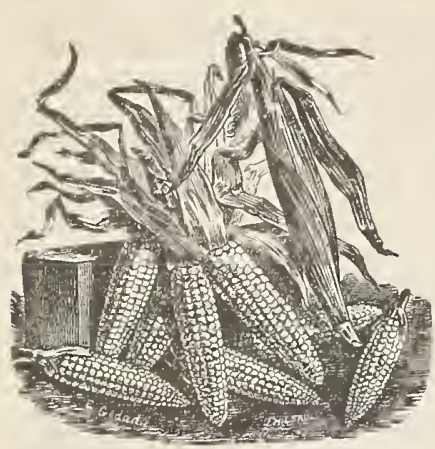

Early Metropolitan.

Mammoth White Cory. The earliest 12-rowed sweet corn, large grains of fine quality. $\frac{1}{3}$ pt. $10 \mathrm{c}, \mathrm{pt} .20 \mathrm{c}, \mathrm{qt} .35 \mathrm{c}$, postage paid; by express, $\frac{1}{2}$ pk. $50 \mathrm{c}, \mathrm{pk} .90 \mathrm{c}$.

Early Metropolitan. A new sort only a few days later than Cory with ears a little larger which are sweet and tender. It is an excellent variety for market gardeners on account of its earliness, size, productiveness and quality. $\frac{7}{3}$ pt. $10 \mathrm{c}$, pt. $20 \mathrm{c}, \mathrm{qt} .35 \mathrm{c}$, postage paid; by express, $\frac{1}{2} \mathrm{pk}$. $75 \mathrm{c}, \mathrm{pk}$ $\$ 1.25$, bu. $\$ 4$.

Extra Early Adams. The very earliest variety, and brings good prices when first offered to the market. $\frac{7}{3}$ pt. $10 \mathrm{c}$, pt. $15 \mathrm{c}$, qt. $30 \mathrm{c}$, postage paid; by express, $\frac{3}{2} \mathrm{pk} .50 \mathrm{c}$, pk. $75 \mathrm{c}, \mathrm{bu} . \$ 2.75$.

Extra Early Sheffield. One of the earliest, combining the robust hardiness of the Adams Extra Early, and the fine sugary quality of the Cory. Fine for early planting. $\frac{1}{3}$ pt. $10 \mathrm{c}$, pt. $20 \mathrm{c}$, qt. $35 \mathrm{c}$, postage paid; by express, $\frac{1}{2} \mathrm{pk} .75 \mathrm{c}$, pk. $\$ 1.25$, bu. $\$ 4$.

Early Melrose. Produces fine large ears, fully nine to ten inches long, and fills out well to the very end. One of the best large, early sweet corns on our list. $\frac{1}{3}$ pt. $10 \mathrm{c}$, pt. 20c, qt. $35 \mathrm{c}$, postage paid ; by express, ${ }_{2}^{1}$ pk. $75 \mathrm{c}, \mathrm{pk}$. $\$ 1.25$, bu. $\$ 4$

Early or Large Adams. One of the most profitable varieties for early market; ears good size, sweet and tender. $\frac{1}{3}$ pt. $10 \mathrm{c}$, pt. $15 \mathrm{c}$, qt. $35 \mathrm{c}$, postage paid ; by express, $\frac{1}{2}$ pk. $50 \mathrm{c}, \mathrm{pk} .75 \mathrm{c}$, bu. $\$ 2.75$.

Schwill's Early Surprise. See Novelty Sheets for description and price.

Schwill's Early Market. Very large ears, grows rapidly. Used both as garden and field corn. $\frac{1}{3}$ pt. 10c, pt. 15c, qt. $30 \mathrm{c}$, postage paid ; by express, $\frac{1}{2}$ pk. 40c, pk. 60c, bu. \$2.25.

Clarke County Champion. A favorite corn, matures early, handsome good size ears. $\frac{1}{3}$ pt. 10c, pt. $15 \mathrm{c}$, qt. $30 \mathrm{c}$, postage paid; by express, $\frac{1}{2}$ pk. $40 \mathrm{c}$, pk. 60 c, bu. $\$ 2$.

Henderson's Early Sugar. One of the best medium early sorts, full, large ears, sweet and tender. $\frac{1}{3}$ pt. $10 \mathrm{c}$, pt. $20 \mathrm{c}$, qt. $35 \mathrm{c}$, postage paid ; by express, $\frac{7}{3}$ pk. 50 c, pk. 90c, bu. $\$ 3.50$.

Egyptian Sugar. Very productive, large size ears, fills well. $\frac{1}{S} \mathrm{pt} .10 \mathrm{c}$, pt $20 \mathrm{c}$, qt. 35c, postage paid; by express, $\frac{1}{2}$ pk. 50c, pk. 90c, bu. $\$ 3.50$.

Triumph Sugar. In sweetness and delicious flavor unsurpassed; no other variety can compare with it. $\frac{1}{3}$ pt. $10 \mathrm{c}$, pt. $20 \mathrm{c}$, qt. $35 \mathrm{c}$, postage paid; by express, 2 pk. $50 \mathrm{c}, \mathrm{pk} .90 \mathrm{c}, \mathrm{bu} . \$ 3.50$.

Stowell's Evergreen. The standard main crop, hardy and productive. $\frac{1}{3} \mathrm{pt}$ $10 \mathrm{c}$, pt. 20c, qt. $30 \mathrm{c}$, postage paid; by express, $\frac{1}{2} \mathrm{pk} .50 \mathrm{c}, \mathrm{pk} .90 \mathrm{c}$, bu. $\$ 3.50$.

Country Gentleman. Shoepeg grain, ears full size, sweet and very tender. pt. 10c, pt. 20c, qt. 30c, postage paid; by express, $\frac{1}{2}$ pk. $50 \mathrm{c}$, pk. $90 \mathrm{c}$, bu. $\$ 3.50$.

Mammoth, or Large Sugar. Largest ears of any, rich and sweet. 10c, pt. 20c, qt. 30 c, postage paid; by express, 2 pk. 50c, pk. $90 \mathrm{c}$, bu. $\$ 3.50$.

Large White Flint. Ears long, even rowed, and very productive. $\frac{1}{3} \mathrm{pt} .10 \mathrm{c}$, pt. $20 \mathrm{c}$, qt. 30 , postage paid; by express, $\frac{1}{2}$ pk. $50 \mathrm{c}, \mathrm{pk} .75 \mathrm{c}$, bu. $\$ 2.75$.

\section{SWEET CORN ON EAR.}

We can furnish fine specimen ears of above varieties, 5 c each, by mail 10c. Pint and Quart Prices Include Postage. If to go by exexpense, deduct 1 o from quart prices and $10 \mathrm{c}$ from pint prices quoted on corn.

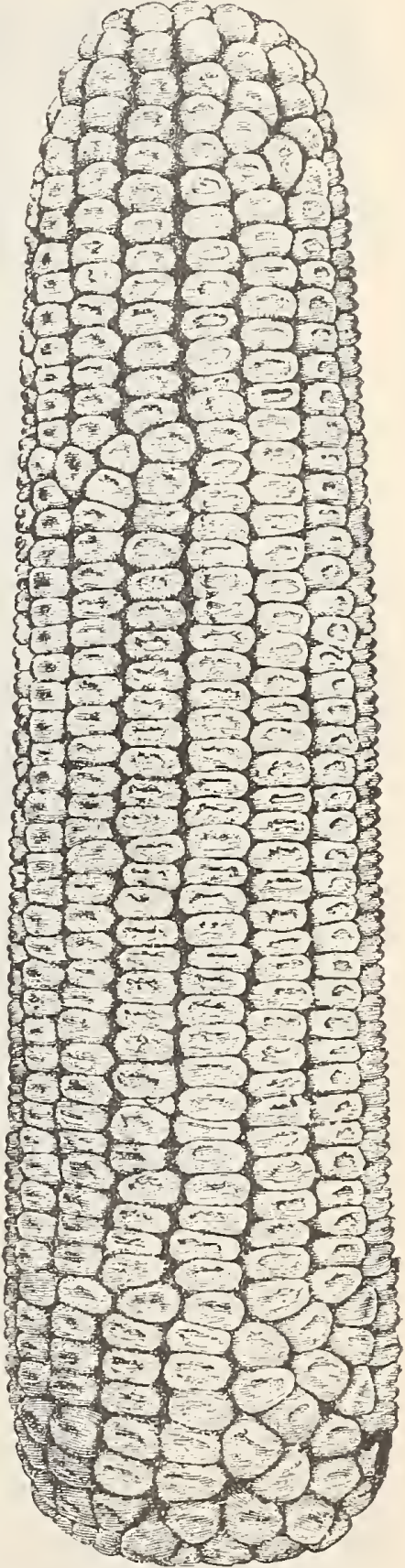

Schwill's Early Market corn.

Should you receive two or more catalogues alike, which sometimes occurs, have the kindness to present such as you do not need to others who will likely want plants or seeds. By doing so you will confer a double favor. We will also feel thankful for your recommendations of our establishment to your friends wanting plants. A copy of our catalogue will be furnished to your friends on receipt of their address. 
PACKETS OF PEAS OR REANS ARE HEAVY and the pack. ets put up by some seedsmen to sell at 5e, postpaid. contain TOO SMALL a quantity for any family. We therefore pat ap LIBERA. SIzED PACIKETS at loc, postpaid. We prefer to please onr customers rather than disappoint them.

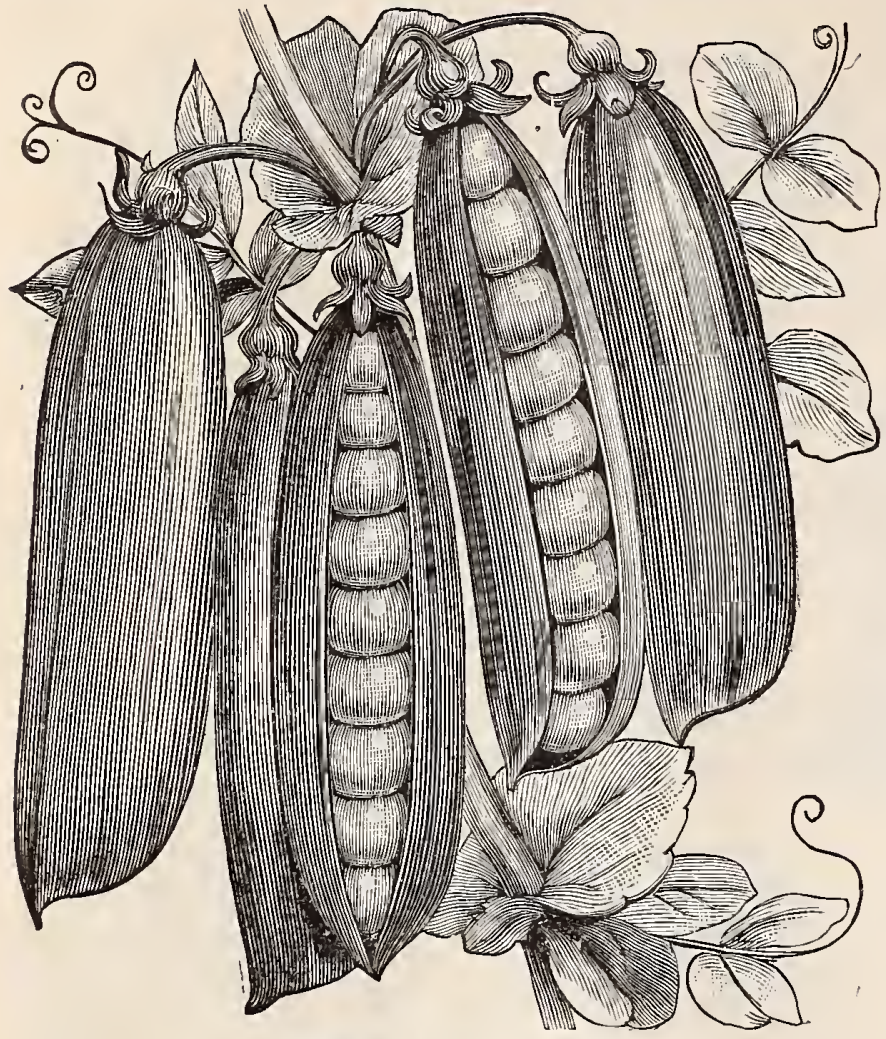

True Extra Early Alaska.

First and Best Extra Early. A standard extra early sort, productive, height two and one-half feet. $\frac{1}{3}$ pt. $10 \mathrm{c}, \frac{1}{2} \mathrm{pt} .15 \mathrm{c}, \mathrm{pt} .25 \mathrm{c}$, qt. $40 \mathrm{c}$, postage paid; by express, $\frac{1}{2} \mathrm{pk}$. $\$ 1$, pk. $\$ 1.50$, bu. $\$ 6$.

Extra Early Maud S. Pods well filled, extremely early, a fine market variety, height two and one-half feet. $\frac{1}{3} \mathrm{pt} .10 \mathrm{c}, \frac{1}{2} \mathrm{pt} .15 \mathrm{c}, \mathrm{pt}$. $25 \mathrm{c}$, qt. $40 \mathrm{c}$, postage paid ; by express, $\frac{1}{2}$ pk. $\$ 1$, pk. $\$ 1.50$, bu. $\$ 6$.

Extra Early Tom Thumb. Very early and prolific and very dwarf, growing only ten to twelve inches high. $\frac{1}{3}$ pt. $10 \mathrm{c}, \frac{1}{2} \mathrm{pt} .15 \mathrm{c}$, pt. 25 c, qt. 40 c, postage paid ; by express, $\frac{1}{2}$ pk. $\$ 1$, pk. $\$ 1.50$, bu. $\$ 5.75$.

Wm. Hurst. Hardy, prolific, extremely early, dwarf, wrinkled pea. Height eight to twelve inches. $\frac{1}{3} \mathrm{pt} .10 \mathrm{c}, \frac{1}{2} \mathrm{pt} .15 \mathrm{c}, \mathrm{pt} .30 \mathrm{c}$, qt. 50 c, postage paid; by express, $\frac{1}{2}$ pk. $\$ 1$, pk. $\$ 1.50$, bu. $\$ 5.50$.

Philadelphia Extra Early. A well known, standard, extra early variety, immensely productive. $\frac{1}{3}$ pt. $10 \mathrm{c}, \frac{1}{2}$ pt. $15 \mathrm{c}$, pt. $25 \mathrm{c}$. qt. $40 \mathrm{c}$, postage paid; by express, $\frac{7}{2}$ pk. $\$ 1$, pk. $\$ 1.50$, bu. $\$ 6$.

ASPARAGUS CUITURE. By James Barnes and William Robinson, F.L.S. The best methods employed in England and France. With translation of Mr. Leboeuf's Essay on Asparagus, and particulars of the seven years' competition instituted for its improvement. Price 50 cents.

\section{WE PAY THE POSTAGE}

At prices quoted on Quarts, Pints and Packets. If to go by express at buyer's expense, 15 cents from quart or 10 cents from pint prices may be deducted.

\section{Garden Peas.}

One quart to 100 feet drill; $1 \frac{1}{2}$ bushels to the acre. Peas for early crop should be planted in the spring as soon as the ground can be worked, in light rich soil. Fresh manure should not be used, as it has a tendency to cause the vines to grow too rank and tall.

\section{EXTRA EARLY VARIETIES.}

Gradus or Prosperity is a long step in the pea world toward prosperity, as it combines earliness with large size in a greenwrinkled pea. This is what the market gardener wants. "They fill the bushel basket." In earliness they follow closely after the first earlies. In height they are two and one-half to three feet. The vine is robust, and the foliage very vigorous, bearing their handsome, large pods profusely over the vine. $\frac{1}{3}$ pt. $10 \mathrm{c}, \frac{1}{2} \mathrm{pt} .20 \mathrm{c}$, pt. $35 \mathrm{c}$, qt. $60 \mathrm{c}$, postage paid.

Extra Early Alaska. The earliest blue pea, very uniform in growth. The dark green pods make it extremely desirable, as it can be carried long distances without losing color, which quality, combined with its earliness and uniformity of ripening, makes it a most desirable extra early pea for market gardeners and shippers; height, two feet. $\frac{1}{3}$ pt. $10 \mathrm{c}, \frac{1}{2}$ pt. $15 \mathrm{c}$, pt. $25 \mathrm{c}$. qt. $45 \mathrm{c}$, postage paid ; by express, $\frac{1}{2}$ pk. $\$ 1$, pk. $\$ 1.50$, bu. $\$ 6$.

McLean's Little Gem. A dwarf first early pea, very prolific and of superior flavor, height one and one-half feet. $\frac{1}{3} \mathrm{pt} .10 \mathrm{c}, \frac{1}{2} \mathrm{pt}$. $15 \mathrm{c}$, pt. $25 \mathrm{c}$, qt. $45 \mathrm{c}$, postage paid; by express, $\frac{1}{2}$ pk. $\$ 1$, pk. $\$ 1.75$, bu. $\$ 7$.

American Wonder. A very fine, extra early wrinkled variety. It is well suited for the private garden and quite productive. Its dwarf habit of growth makes it a desirable sort, height ten inches. $\frac{1}{3} \mathrm{pt} .10 \mathrm{c}, \frac{1}{2} \mathrm{pt}$. $15 \mathrm{c}$, pt. 25c, qt. $45 \mathrm{c}$, postage paid; by express, $\frac{1}{2}$ pk. $\$ 1$, pk. $\$ 1.75$, bu. $\$ 7$.

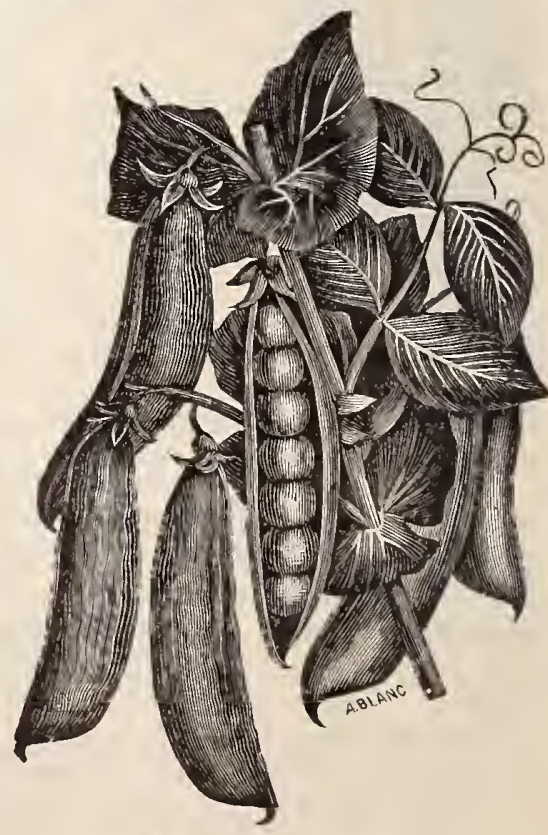

McLean's Little Gem. 


\section{Early and Medium Peas.}

Bliss' Everbearing. A variety maturing soon after the Premium Gem, and continuing a long time in bearing. Peas wrinkled, large, very tender, superior flavor. $\frac{1}{3}$ pt. $10 \mathrm{c}, \frac{1}{2}$ pt. $15 \mathrm{c}$, pt. $25 \mathrm{c}$, qt. $40 \mathrm{c}$, postage paid; by express, $\frac{1}{2}$ pk. $\$ 1$, pk. $\$ 1.50$, bu. $\$ 6$.

Pride of the Market. They require no sticks, and are unequalled in productiveness, robust, free-branching, eighteen to twenty inches high. $\frac{1}{3} \mathrm{pt} .10 \mathrm{c}, \frac{1}{2} \mathrm{pt} .15 \mathrm{c}$, pt. 25 c, qt. 40 c, postage paid; by express, $\frac{1}{2}$ pk. $\$ 1$, pk. $\$ 1.50$, bu. $\$ 6$.

The "Daisy" Pea. A new, early dwarf pea, with immense pods and peas, vines from sixteen to eighteen inches high. The self-supporting, stout plants are fairly loaded with large, bright green pods, which are always well filled. $\frac{1}{3}$ pt. $10 \mathrm{c}, \frac{1}{2} \mathrm{pt} .15 \mathrm{c}$, pt. 25 c, qt. 40c, postage paid; by express, $\frac{1}{2}$ pk. $\$ 1$, pk. $\$ 1.75$, bu. $\$ 6.50$.

Duke of Albany. One of the very largest and best peas grown. The pods are well-filled and borne in great profusion. $\frac{1}{3}$ pt. $10 \mathrm{c}, \frac{1}{2} \mathrm{pt} .15 \mathrm{c}, \mathrm{pt} .25 \mathrm{c}, \mathrm{qt} .45 \mathrm{c}$, postage paid; by express, $\frac{1}{2}$ pk. $\$ 1$, pk. $\$ 1.50$, bu. $\$ 5.50$.

Early May. Good standard market sort, not so early as other sorts, but continues in bearing longer. $\frac{1}{3}$ pt. $10 \mathrm{c}, \frac{1}{2}$ pt. $15 \mathrm{c}$, pt. $25 \mathrm{c}$, qt. $40 \mathrm{c}$, postage paid; by express, $\frac{1}{2} \mathrm{pk} . \$ 1, \mathrm{pk} . \$ 1.50$, bu. $\$ 5.50$.

\section{Late Peas.}

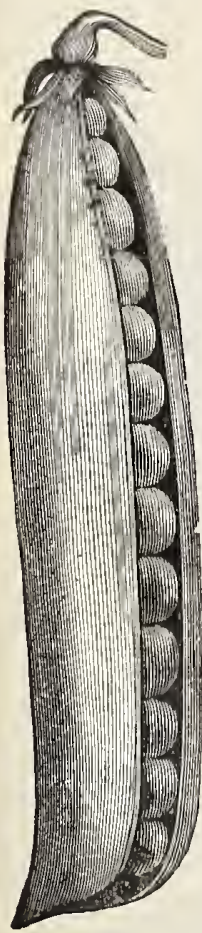

Telephone Pea.
The Telephone Pea. No pea today, of its class, is more meritorious or deservedly popular than the Telephone. Green wrinkled, height three and one-half feet, productive, pods unusually large, elegant shape, slightly curved, and well filled with peas of large size and most excellent quality. $\frac{1}{3}$ pt. $10 \mathrm{c}, \frac{1}{2} \mathrm{pt} .15 \mathrm{c}, \mathrm{pt} .25 \mathrm{c}$, qt. $45 \mathrm{c}$, postage paid; by express, $\frac{1}{2} \mathrm{pk}$. $\$ 1$, pk. $\$ 1.75$, bu. $\$ 6.50$.

Juno Pea. The Juno is one of the best main crop wrinkled peas of its class. The pods are very thick, broad-backed and filled from the stem to the tips with seven to nine sweet, delicious, dark green peas of immense size; height two feet. $\frac{1}{3}$ pt. $10 \mathrm{c}, \frac{1}{2}$ pt. $15 \mathrm{c}$, pt. $25 \mathrm{c}$, qt. $45 \mathrm{c}$, postage paid; by express, $\frac{1}{2}$ pk. $\$ 1$, pk. $\$ 1.50$, bu. $\$ 5.50$.

Champion of England. One of the best. Delicious flavor, profuse bearer of large pods well filled with large green wrinkled peas; height four feet. $\frac{1}{3} \mathrm{pt} .10 \mathrm{c}, \frac{1}{2} \mathrm{pt}$. $15 \mathrm{c}$, pt. $25 \mathrm{c}$, qt. $40 \mathrm{c}$, postage paid ; by express, $\frac{1}{2} \mathrm{pk} .75 \mathrm{c}$, pk. $\$ 1.50$, bu. $\$ 5.00$.

Large Blackeyed Marrowfat. Extensively grown as garden peas, as they are hardy, productive and bear well-filled pods; four feet high. $\frac{1}{8}$ pt. 10c, $\frac{1}{2}$ pt. 15c, pt. 20c, qt. 35c, postage paid; był express, $\frac{1}{2}$ pk. 50c, pk. 90 c, bu. $\$ 3.50$.

Large White Marrowfat. A favorite market sort, large, broad pods, well filled; five feet high. $\frac{1}{8}$ pt. $10 \mathrm{c}$, $\frac{1}{2}$ pt. 15c, pt. 20c, qt. 35c, postage paid; by express, $\frac{1}{2}$ pk. 50c, pk. $90 \mathrm{c}$, bu. $\$ 3.50$.

Melting Sugar. New variety; height five feet; very large, broad, handsome, light green (nearly white) pods, so brittle that they snap without strings. $\frac{1}{3} \mathrm{pt} .15 \mathrm{c}, \frac{1}{2} \mathrm{pt}$. $20 \mathrm{c}$, pt. 30c, qt. 50c, postage paid; by express, $\frac{1}{2}$ peck $\$ 1.50$, pk. $\$ 2.00$, bu. $\$ 7.00$.

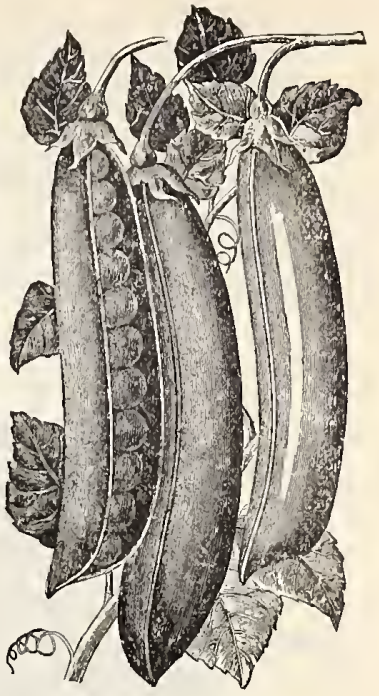

Duke of Albany Pea.

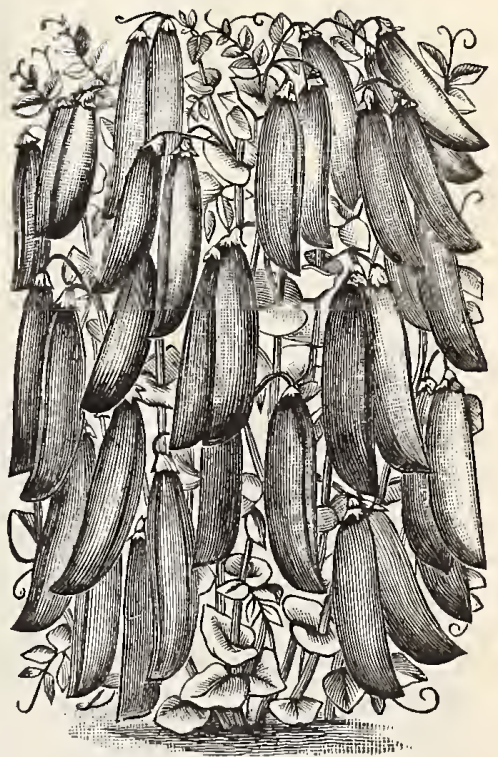

Champion:of England Pea.

\section{Schwill's Star Collection. Twelve Papers Assorted Flower Seeds for only}

We will send postage paid, to any address, one paper each of the following Flower Seed upon receipt of price :

Asters, China Mixed.

Sweet. Alyssum.

Nasturtium, Dwarf Mixed.

Mignonette, Sweet.
Pansy, Mixed.

Poppy, Carnation, Mixed.

Cypress Vine, Mixed.

Petunia, Single Mixed.
Pink, China, Double, Mixed.

Phlox Drummondii, Mixed.

Sweet Peas, Mixed.

Verbena, Mixed.

\section{Schwill's Banner Collection.}

\section{Twelve Packets Garden Seeds for only 25 Cents, Postage Paid.}

One packet each of the following Garden Seeds will be sent postage paid upon receipt of price.

Beet, Early Blood Turnip.

Cabbage, Early Wakefield.

Collards, Southern or Georgia.

Cucumber, Early White Spine.
Lettuce, Large White Cabbage.

Melon, Georgia Rattlesnake.

Mustard, Southern Giant Curled.

Parsley, Double Curled.
Radish, Early Scarlet Turnip.

Squash, Early White Bush.

Tomato, Early Acme.

Turnip, Purple Top Flat. 


\section{BEETS.}

One ounce to fifty feet drill, four to five pounds to the acre in drills. Beets require a deep rich and mellow soil. Drop abnut one inch deep in drills twelve to eighteen inches apart. Thin to six and twelve inches, and hoe often until the tops corer the ground. In dry weather it is a good idea to soak the seed before planting.

5c per packet, or three packets for $10 \mathrm{c}$, any variety, postpaid.

If beet seed are ordered by express, deduct 10c per lb. from following prices.

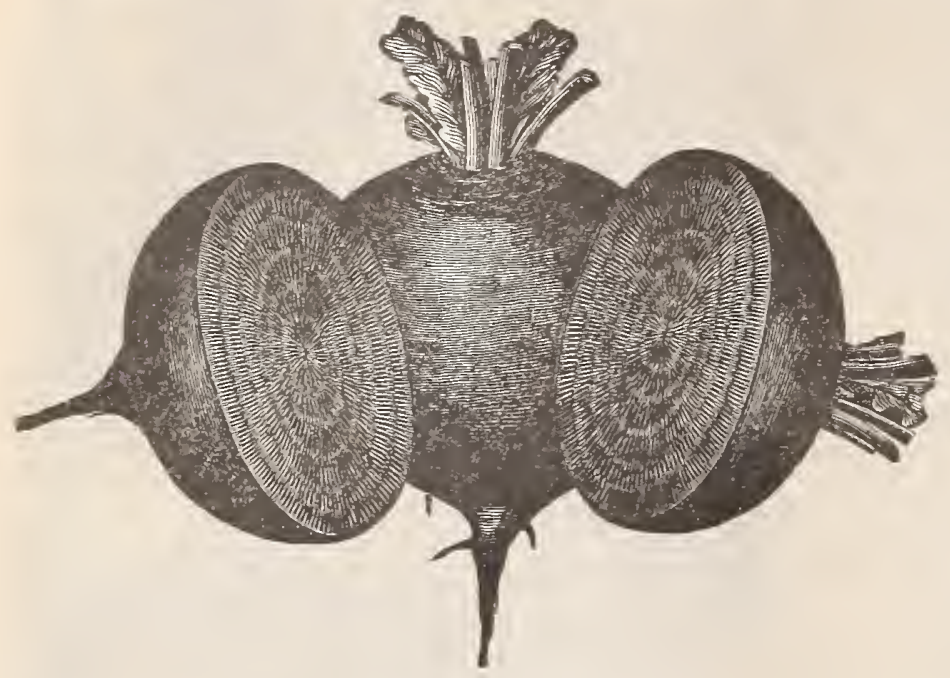

Crosby's Egyptian. An improved strain of the Egyptian beet, specially recommended as an extra early sort. 1t is much thicker than the origiual strain, of better color and quality, besides being smoother and just as early. Oz. 10c, 2 oz. 15c, l lb. $25 \mathrm{c}, 1 \mathrm{~b} .70 \mathrm{c}$, postage paid.

Columbia. Smooth and regular, turnip shaped, flesh blood red aud of fine table quality. One of the best for market. Oz. 10c, 2oz. 15ce, $\frac{1}{4} 1 \mathrm{~b} .20 \mathrm{c}, 1 \mathrm{~b}$. 50 c, postage paid.

Bastain's Early Blood Turnip. An early, light colored beet, very smooth and of fine form. Oz. 10c, 2 oz. 15c, lb. $20 \mathrm{c}, 1 \mathrm{~b} .50 \mathrm{c}$, postage paid.

Early Eclipse Beet.

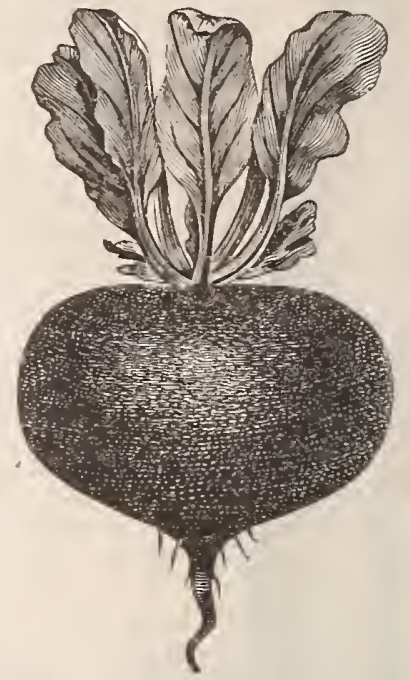

Detroit Dark Blood. Small tops, beautiful round shape, dark red color, flesh always tender and sweet. A tine market rariety. Oz. 10c, 2 oz. 15̄c, ] lb. $20 \mathrm{c}, \mathrm{lb} .60 \mathrm{c}$, postage paid.

Early Eclipse. An improved extra early sort. Tops small, dark purplishgreen shading to lighter color on outside of the leaves. Roots nearly globular, with a small tap root and a rery small collar. Flesh dark red, zoned with a lighter red; very sweet, crisp and tender, especially when young. $\mathrm{Oz} .10 \mathrm{c}$, 2 oz. $15 \mathrm{c}, \frac{1}{1}$ lb. 20c, lb. $60 \mathrm{c}$, postage paid.

Fxtra Early Dark Red Egyptian. One of the earliest ; very deep red, tender and delicious. The leading market sort, and best for forcing. Oz. 10c, 2 az. $15 \mathrm{c}$, lb. 20c, lb. 50c, postpaid.

Extra Early Bassano. Roots light red, turnip shaped; flesh tender and juicy and boils white. Oz. 10c, $2 \mathrm{oz} .15 \bar{c}, \frac{1}{4} 1 \mathrm{~b} .20 \mathrm{c}, 1 \mathrm{~b} .50 \mathrm{c}$, postage paid.

Improved Early Blood Turnip. The standard sort; blood red, turnip shaped and very tender. Oz. 10c, 2 oz. 15c, lb. 20c, lb. 50c, postage paid. Extra Early Dark Red Egyptian Beet.

Edmand's Early Blood Turnip. Of good form, round with only one single tap root. The flesh is of a deep red color. Oz. 10c, 2 oz. 15c, $\frac{1}{4}$ lb. $20 \mathrm{c}, 1 \mathrm{~b} .60 \mathrm{c}$, postage paid.

Improved Long Blood Red. A well known hardy variety; grows from ten to fourteen inches long. $\mathrm{Oz}$. $10 \mathrm{c}, 2 \mathrm{oz}$. 1.5c, 1b. $20 \mathrm{c}, 1 \mathrm{~b} .50 \mathrm{c}$, postage paid.

New Crimson Globe. Fine globular shape, flesh ricli deep purple, fine quality, extremely early, smooth and a good keeper. Oz. 10c, 2 oz. $15 \mathrm{c}, \frac{1}{1} 1 \mathrm{~b} .20 \mathrm{c}, 1 \mathrm{~b} .60 \mathrm{c}$, postage paid.

Dirigo. A new variety, darker in color than Eclipse and slightly larger flesh tender and sweet. $\mathrm{Oz} .10 \mathrm{c}$, $2 \mathrm{oz} .15 \mathrm{c}, \frac{1}{4} \mathrm{lb} .20 \mathrm{c}, 1 \mathrm{~b} .60 \mathrm{c}$, postage paid.

\section{Mangel Wurzels and Sugar Beets. STOCK FEED.}

Sow four to six pounds to the acre. Plant a few for your stock by all means. Sow in drills two feet apart. They yield enormously and are very nutritious.

Select Mammoth Long Red. The heaviest croppers and smoothest variety of long mangels. Excellent keepers. Oz. 10c, 1 lb. 15c, 1b. 40c, postage paid.

White Sugar Beet. The large amount of saccharine matter contained in this variety makes it rery valuable for stock feeding purposes. Oz. 10c, $\frac{1}{4}$ lb. $15 \mathrm{c}, 1 \mathrm{~b} .40 \mathrm{c}$, postage paid.
Golden Tankard. The best of the intermediate sort ; very nutritious, color bright yellow. Oz. 10c, $\frac{1}{\ddagger} \mathrm{lb} .15 \mathrm{c}$, lb. $45 \mathrm{c}$, postage paid.

Klein Wanzleben. A new rariety of sugar beet. Contains the greatest amount of sugar of any. Large, smooth, fine grained and an exceeding heavy cropper. Oz. 10c, 1b. 15c, lb. $45 \mathrm{c}$, postage paid. 


\section{CABBAGE.}

(Best American Grown Seed.)

This is the most important crop to the market gardener and small grower, and too much caution cannot be exercised in knowing that the seed is reliable and true. Our seeds are grown with the utmost care, and we know they are fresh, pure, reliable and true to name, and that they have been grown from the heads only, and these most carefully selected. One ounce will produce about 2000 plants. For early use, sow the seeds in hotbeds in January or February, or may be sown about the middle of October, and the plants wintered over in cold frames. Transplant in spring as soon as the ground can be worked, in rows two feet apart, and the plants eighteen inches apart in the rows. For late or winter use, the seed should be sown in June and the plants set out in July, $2 \frac{1}{2} \times 3$ feet.

\section{Packet 5c, 3 packets 10c, any variety on our list, except where noted otherwise.}

We sell $1 / 2$ ounce packets of cabbage seed at ounce rates, $1 / 2$ pounds at pound rates.

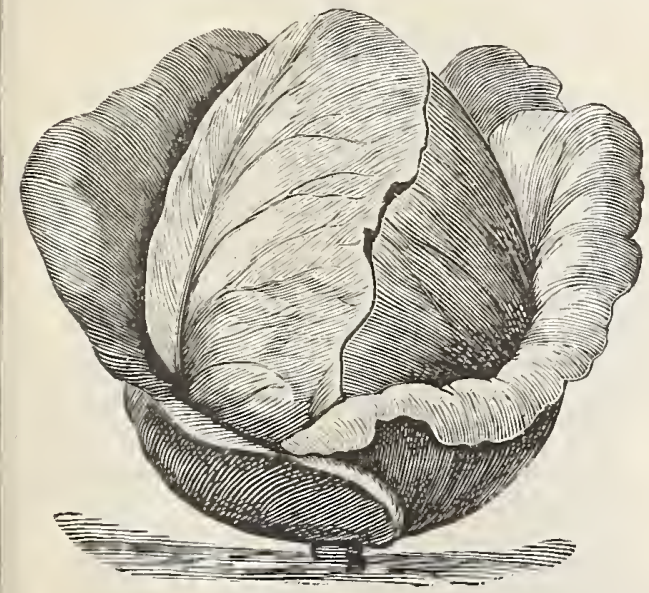

Extra Early Express ('abbage.

Extra Early Express. Earliest cabbage in the world. While not quite so large as Jersey Wakefield, it is several days earlier, and for a first early variety cannot be excelled. Resem bles the Etampes, having solid compact heads of conical form, very dwarf and uniform. Oz. 25c, a lb. 75c, lb. \$2.

Early Jersey Wakefield. Selected stock. Many market gardeners consider this the very best early cabbage in cultivation. Certainly deserving of its great popularity. Grown extensively for market and shipping. Its merits are many, among which are: large heads for an early sort, small outside foliage, and uniformity of crop. Pyramidal in shape, having a blunted or rounded peak. The seed we offer is first-class; sure to give satisfaction. Oz. $25 \mathrm{c}, \frac{1}{4} \mathrm{lb} .75 \mathrm{c}, \mathrm{lb} . \$ 2.50$, postage paid.

Charleston or Large Wakefield. Selection from Early Jersey Wakefield, only it is about one week later than that popular early variety, but grows much larger, heads often averaging from 15 to 18 pounds; as solid as Winningstadt. Oz. 25c, $\frac{1}{4} \mathrm{lb}$. $85 \mathrm{c}, \mathrm{lb} . \$ 2.75$.

Selected Early Winningstadt. A sure header, conical shape. Oz. 20c, 2 oz. 35c, $\frac{1}{4}$ lb. 60c, lb. $\$ 1.75$.

Early Dwarf York. An old favorite, heads heart-shaped. Oz. 15 c, 2 oz. $25 \mathrm{c}, \frac{1}{4}$ lb. $40 \mathrm{c}, \mathrm{lb} . \$ 1.50$.

Large Early York. Heads larger than Early York. Good for early market. Oz. $15 \mathrm{c}, \frac{1}{4} \mathrm{lb}, 40 \mathrm{c}, \mathrm{lb} . \$ 1.50$.

Henderson's Early Summer. Selected stock. About ten days later than the Early IVakefield, but being fully double the size. It may be classed as decidedly the best large early cabbage, and it is deservedly popular with market gardeners. Equal in weight to most of the late varieties, and its short outer leaves allow it to be planted nearly as close as Wakefield Oz. 25c $\frac{1}{4}$ lb. $75 \mathrm{c}, \mathrm{lb} . \$ 2.50$.

s All Head, Early. The largest heading of the second early sorts, of excellent quality. The deep flat heads are renıarkably solid, and very uniform in size. Oz. 25c, $2 \mathrm{oz} .45 \mathrm{c}, \frac{1}{4} \mathrm{lb} .85 \mathrm{c}$, lb. $\$ 2.75$.

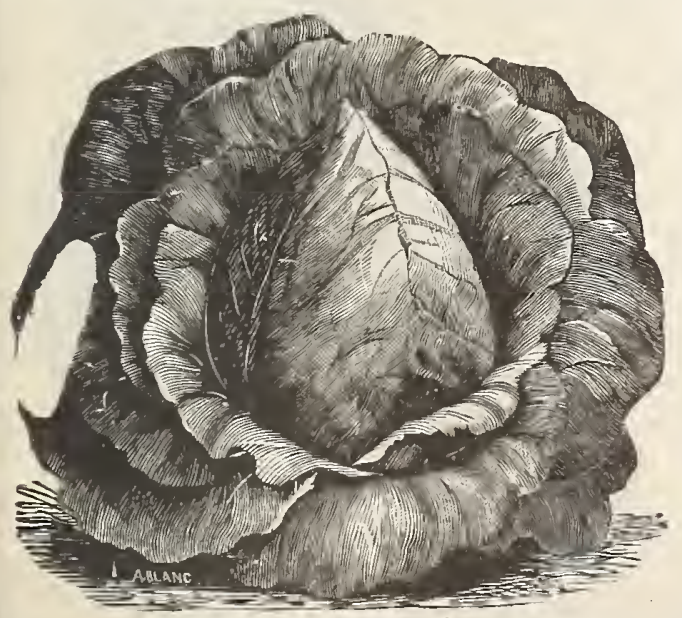

Early Jersey Wakefield Cabbage.

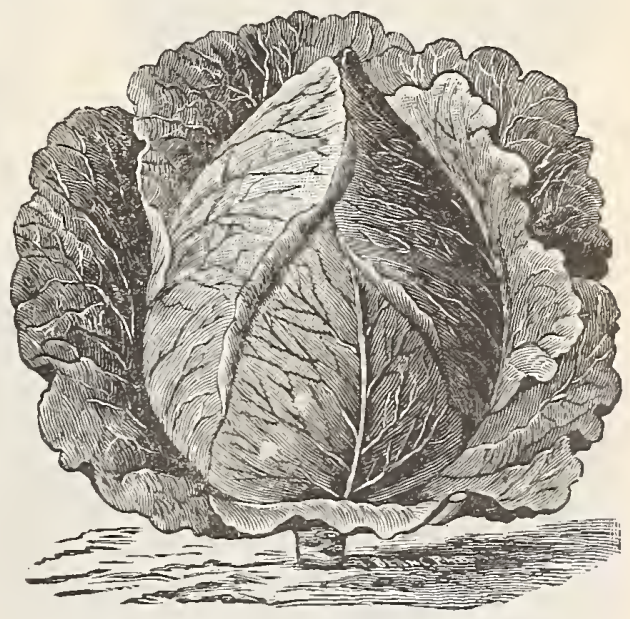

Charleston or Large Wakefield Cabbage.

ALFALFA.-By F. D. Coburn. Its growth, uses and feeding value. The fact that alfalfa thrives in almost any soil; that without reseeding it goes on yielding two, three, four and sometimes five cuttings annually for five, ten or perhaps one hundred years; and that either green or cured it is one of the most nutritious forage plants known, gives reliable information upon its production and uses of unusual interest. Such information is given in this volume for every part of America, by the highest authority. Illustrated, $5 \times 7$ inches, 160 pages. Price 50c. 


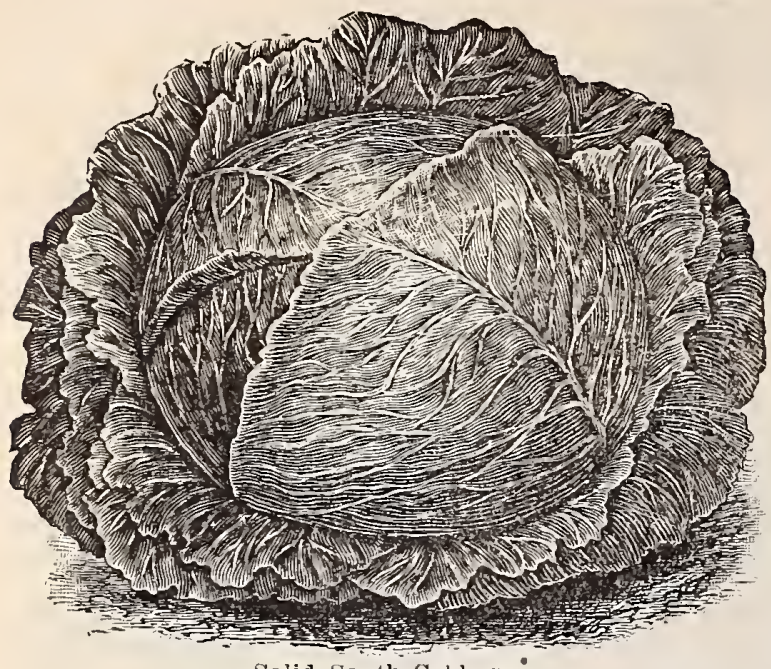

Solid South Cabbage.

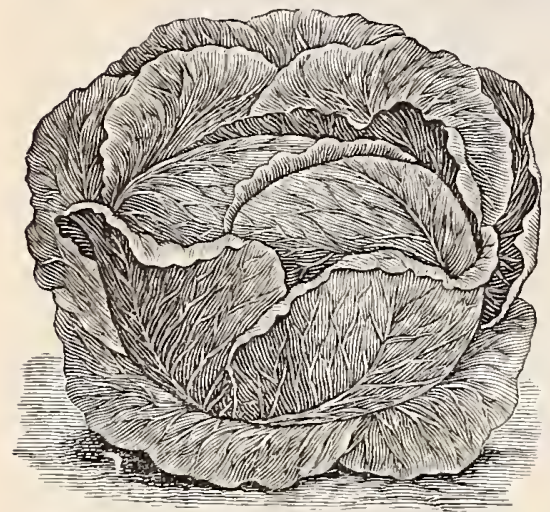

Succession Cabbage.

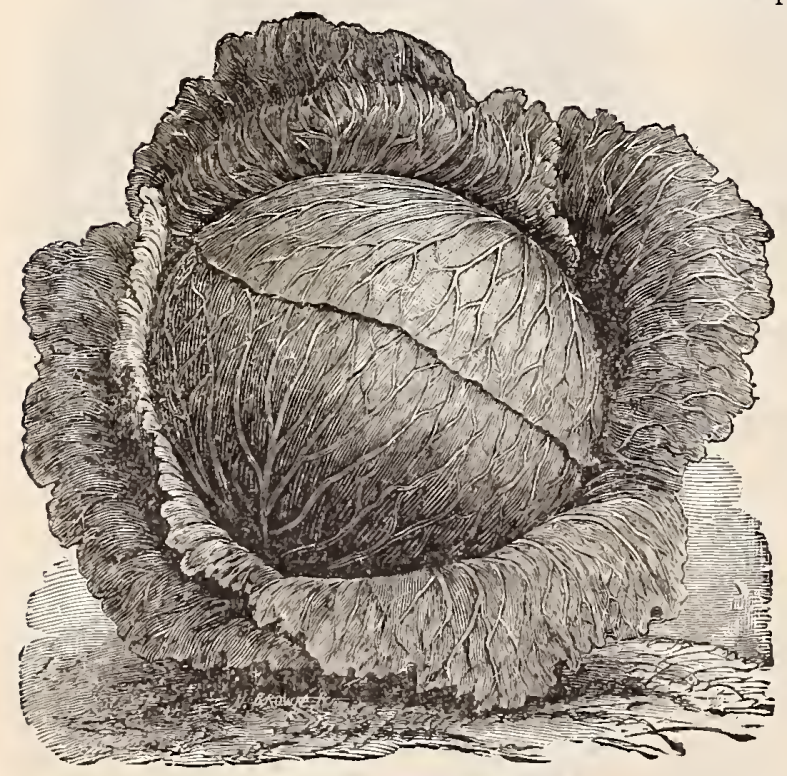

Schwill's Ideal Winter Cabbage. lb. $\$ 2.25$.

\section{CABBAGE-Continued.}

Succession. Early maturing, a little later than Early Summer, and is twice its size. Although this variety is largely grown to come in for midsummer use, it is also valuable as a fall or winter variety, as its firm, solid head makes it an excellent keeper. Oz. 25c, 2 oz. 45c, $\frac{1}{4} \mathrm{lb} .85 \mathrm{c}, 1 \mathrm{~b} . \$ 2.75$.

Fottler's Improved Brunswick. Good, solid heads, either for second early or late use, keeps well. Oz. 25c, 2 oz. 40c, $\frac{1}{4}$ lb. 70c, lb. \$2.:อ̃.

Solid South. A magnificent cabbage, similar to the Early Summer in shape; is larger, more uniform, has fewer loose leaves, truer to type, and much slower in shooting to seed in the spring if the seed is sown in the fall. Oz. 25c, $2 \mathrm{oz} .45 \mathrm{c}, \frac{1}{4} \mathrm{lb} .85 \mathrm{c}, 1 \mathrm{~b} . \$ 2.75$.

Genuine Surehead. 'This popular cabbage is rightfully named Surehead. It never fails to make a remarkable fine, solid, large head, with few outer leaves. A strong, vigorous grower. Excellent variety for fall cabbage. Oz. $25 \mathrm{c}, 2 \mathrm{oz} .45 \mathrm{c}, \frac{1}{4} \mathrm{lb} .75 \mathrm{c}, \mathrm{lb}$. $\$ 2.50$.

Selected Early Drumhead. A second early, large, round, solid heading variety. $\mathrm{Oz} .20 \mathrm{c}, 2 \mathrm{oz}$. $35 \mathrm{c}, \frac{1}{4}$ lb. $60 \mathrm{c}, \mathrm{lb} . \$ 1.75$.

Louisville Early Drumhead. Heads very large and solid, will stand without bursting almost the entire summer. Oz. $20 \mathrm{c}, 2$ oz. $35 \mathrm{c}$, la lb. $60 \mathrm{c}, \mathrm{lb} . \$ 2$.

Selected Early Flat Dutch. An excellent second early cabbage, producing large, solid heads, of uniform shape, flattened on top, and always making a handsome appearance. Oz. $25 \mathrm{c}, 2 \mathrm{oz} .45 \mathrm{c}, \frac{1}{4} \mathrm{lb}$. $75 \mathrm{c}$,

All Seasons. A true, sure header, growing to a large size. Oz. $25 \mathrm{c}, 2$ oz. $40 \mathrm{c}, \frac{1}{4} \mathrm{lb} .75 \mathrm{c}, 1 \mathrm{~b} . \$ 2.50$.

\section{LATE VARIETIES.}

Improved Large Late Drumhead. A standard late variety, grows large and firm heads. Oz. 20c, 2 oz. 35c, $\frac{1}{4}$ lb. 50c, lb. $\$ 1.75$.

Improved Large Late Flat Dutch. Heads large, bluish green, round, solid and broad on top, more extensively plantcd than any other variety. Oz. 20c, 2 oz. 35c, $\frac{1}{4}$ lb. 50 c, lb. $\$ 1.75$.

Schwill's Ideal Winter. One of the finest strains of late cabbage ever offered. It produces regular, even heads of enormous size, and can be relied upon to produce a greater weight of crop from the same space of ground than most of the late sorts from the fact that it has so few outer leaves. Oz. 25c, 2 oz. 45c, $\frac{1}{4}$ lb. $85 \mathrm{c}, \mathrm{lb} . \$ 2.75$.

Marblehead Mammoth Drumhead. Late, the largest cabbage grown, and for that reason deservedly popular with market gardeners. Oz. $20 \mathrm{c}, 2 \mathrm{oz} .35 \mathrm{c}$, lb. $60 \mathrm{c}, 1 \mathrm{~b} . \$ 2$.

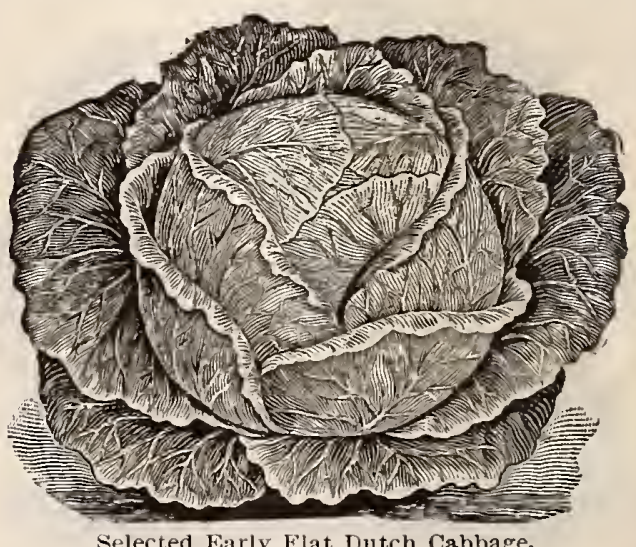

CUSTOMERS WHO ORDER EARLY have their seeds on hand when they want them, and avoid unnecessary delay during the rush of the season. Make out your order as soon as you receive our catalogue, and remember that heavy seeds and large quantities can be sent cheaply by freight and will reach you in time if ordered early. 


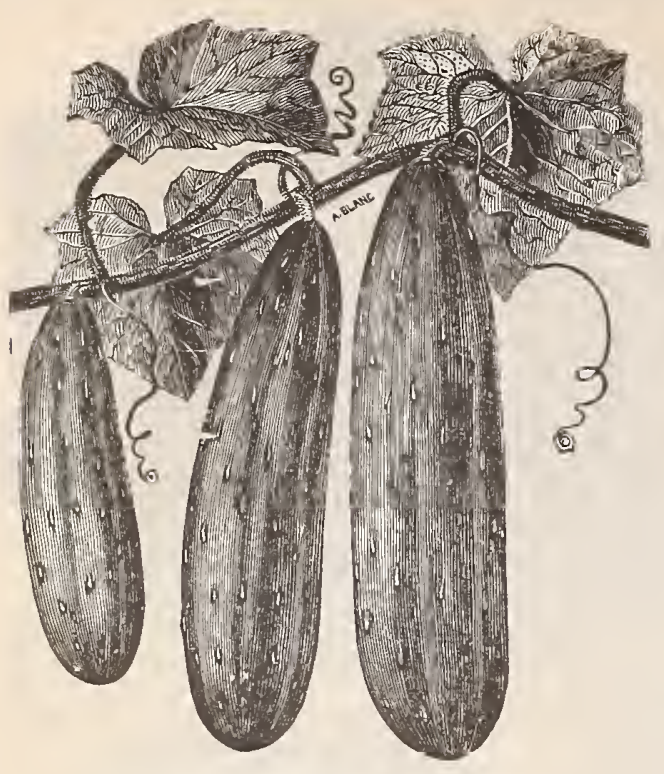

Long Green Turkey Cucumber.

\section{Cucumbers.}

One ounce will plant fifty hills; one to two pounds will plant one acre. Cucumbers succeed best in warm, rich, sandy loam, and should not be planted in open air until there is a prospect of settled warm weather. Plant in hills about four feet apart each way, and when all danger of insects is past, thin out the plants, leaving three or four of the strongest to each hill.

Extra Early Russian. The earliest: small, hardy, very productive, excellent for pickles. Pkt. $5 \mathrm{c}, 0 \mathrm{oz} .25 \mathrm{c}, 2 \mathrm{oz} .40 \mathrm{c}, \frac{1}{4} \mathrm{lb}$. $60 \mathrm{c}, \mathrm{lb} . \$ 1.50$, postage paid.

Giant Pera. Of large size, smooth, straight, free from spines, flesh white, crisp and tender. Pkt. 5c, oz. $25 \mathrm{c}, 20 \mathrm{oz} 40 \mathrm{c}$, $1 \mathrm{~b}$. $60 \mathrm{c}, \mathrm{lb} . \$ 1.75$, postage paid.

Japanese Climbing. Vines extra strong; foliage more vigorous than other kinds, and, being a climbing sort, can be grown on trellises, etc., saving valuable space in small gardens. Very prolific-from forty to fifty havon single plants. Fruits cylindrical about ten inches lo:s; fine flavor. Pkt. 5c, oz. $25 \mathrm{c}, 2 \mathrm{oz} .45 \mathrm{c}, \frac{1}{1}$ lb. $65 \mathrm{c}, 1 \mathrm{~b} . \$ 250$.

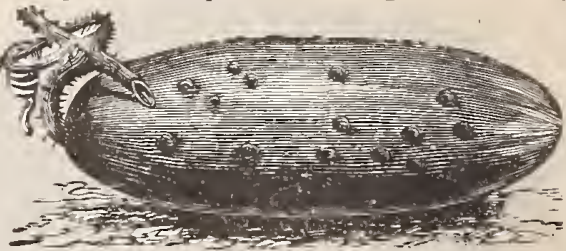

Improved Early White Spine Cueumber.
Long Green Turkey. Fruit very long and slim, beautiful dark green color. Pkt. 5c, 07. 25c, 20z. 45c, 立 lb. 65 c, lb. $\$ 2.25$.

Extra Long White Spine. This variety grows ten to twelve inches long, very straight and handsome, good for forcing. Pkt. 5c, oz. $25 \mathrm{c}, 2 \mathrm{oz}, 40 \mathrm{c}, 1 \mathrm{lb} .60 \mathrm{c}, 1 \mathrm{~b}$. $\$ 1.75$, postage paid.

Improved Long Green. The leading long green variety; dark green, firm and crisp. Pkt. 5̌c, oz. $25 \mathrm{c}, 2$ oz. $45 \mathrm{c}, \frac{1}{4} \mathrm{lb} .75 \mathrm{c}, 1 \mathrm{~b} . \$ 2.50$, postage paid.

Gherkin. Oval shaped, prickly fruit, used. exclusively for pickling. Pkt. 5c, oz. 35 c.

\section{Collards.}

A species of cabhage. Sow in the spring or fa!l, and trans. plant and cultivate in the same nıanner as cabbage.

Prices for any of the following varieties, viz: Pkt. 5c, 3 pkts. $10 \mathrm{c}, \mathrm{oz} .15 \mathrm{c}, 2 \mathrm{oz} .25 \mathrm{c}, 1 / 4$ lb. $40 \mathrm{c}, 1 \mathrm{~b} . \$ 1.25$.

North Carolina Buncombe. A superior variety, heads up in winter, very heavy foliage, fine flavor.

Georgia White Cabbage. Calleci cabbage collard on count of its close, bunching growth and light green leaves.

True Southern. The old standard sort which has beén in use in the South for years.

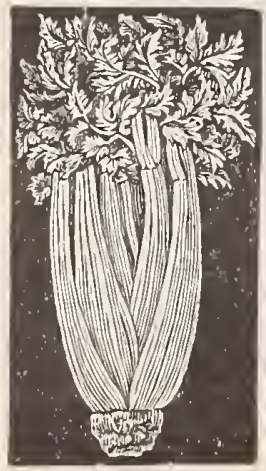

\section{Celery.}

One ounce will produce about 3000 plants. Sow in April or May, and rake the seed in lightly; water and shade from strong sun.

Pkt. 5c, 3 pkts. 10c, $1 / 2$ oz. 15c, oz. $25 \mathrm{c}, 2$ oz. $40 \mathrm{c}, 1 / 4 \mathrm{lb} .75 \mathrm{c}$, any variety.

Henderson's Half Dwarf. A white variety, intermediate in size, crisp and nutty flavor. A favorite with gardeners.

Giant Pascal. A superior keeping sort; it blanches very easily and quickly.

Large White Solid. Grows to a very large size, crisp and tender.

Henderson's White Plume. Very early; requires but little banking up to blanch.

Golden Self-Blanching. Compact, straight, vigorous growth, self-blanching.

Henderson's New Rose. A beautiful rich golden-yellow color, the ribs are tinged with a warm, rosy pink shade ; stalks thick, solid and brittle.

White Plume relery.
Improved Early White Spine. A favorite market vine vines are vigorous and very productive. aid.

Cool and Crisp. As a cucumber for slicing we know none better. Long and slim, pointed at the ends, very

Ve also can supply the well known standard rarieties. rice of each, postage paid, pkt. $5 \mathrm{c}$, oz. $20 \mathrm{c}, 2 \mathrm{oz}$. 35c, $\frac{3}{4}$ Early Frame, Early Green Cluster.
Celaric, or Turnip-Rooted Celery. Sow early in the spring in light, rich soil. 


\section{Cauliflower.}

Pkt. 10 c, $1 / 8$ oz. 40 c, $1 / 4$ oz. 75 c, $1 / 2$ oz. $\$ 1.25$, oz. $\$ 2.50$, any variety.

One ounce will produce about 2000 plants. Sow in hotbed early in January and transplant any time suitable after the first of March Our stock is of the very best quality, making a sure head. We do not handle the cheap grade of cauliflower which can be bought at one-fourth of our prices-such seed is dear at any price. If you cannot afford to buy the best seed do not plant at all.

Extra Early Snowball. One of the best sorts, either for forcing or outdoor culture.

Extra Early Dwarf Erfurt. One of the earliest varieties, small leaved, dwarf for forcing, producing pure white heads of the finest quality.

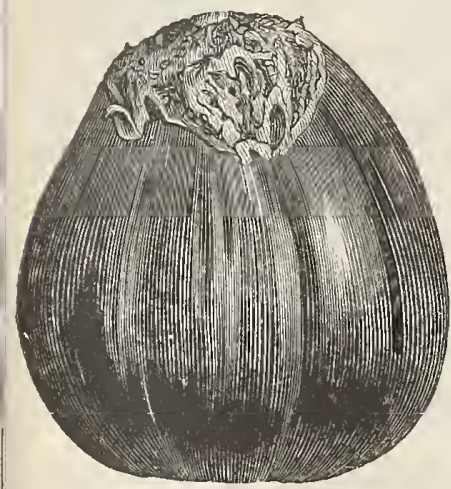

Improved New York Purple Egg Plant.

Gilt-Edge Snowball. Larger and heavier than the preceding variety, finest strain.

Worldbeater. A late variety, vigorous habit. Large, handsome, white heads, well protected by foliage.

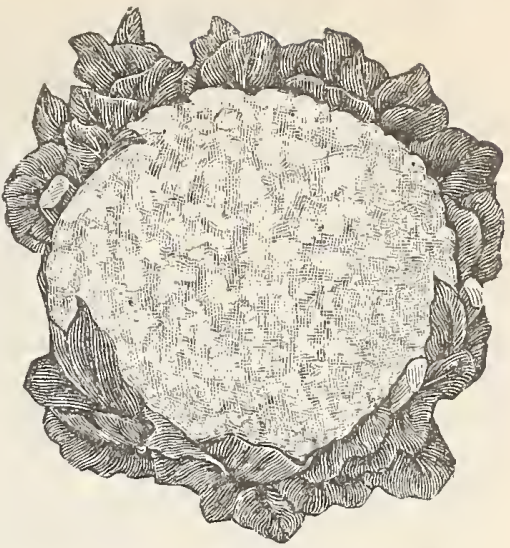

Extra Early Snowball Cauliflower.

\section{Egg Plant.}

One ounce will produce about 1000 plants. A tender plant, which should be started quite early in a hotbed or box in the house, which must be kept warm. Do not put out of doors until mild weather.

Improved New York Purple. This is the favorite market variety ; of large size, smooth, deep purple skin, free from thorns. Pkt. 5c, 送oz. 15c, oz. 30c, 2 oz. $50 \mathrm{c}, \frac{1}{4}$ lb. $90 \mathrm{c}, \mathrm{lb} . \$ 3.50$.

\section{Dver thirty years per-} somal experience with

seeds :: :: :: :: :: :: :: :: ::

\section{Endive.}

One ounce will produce 2000 plants. Sow early and thin. Soon as large enough thin to nine inches apart.

Green Curled. Very ornamental, its leaves being beautifully colored and delicately cut. Pkt. 5c, oz. 20c, 2 oz. $35 \mathrm{c}, \frac{1}{4} 1 \mathrm{lb} .50 \mathrm{c}$, 1b. $\$ 1.75$.

White Curled. A most beautiful variety; leaves almost white. Pkt. 5c, oz. 20c, 2 oz. $35 \mathrm{c}, \frac{1}{4}$ lb. 50c, lb. $\$ 1.75$, postpaid.

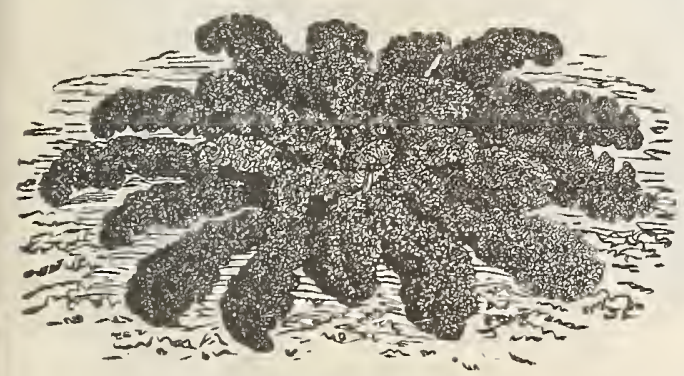

Dwarf German Curled Kale.

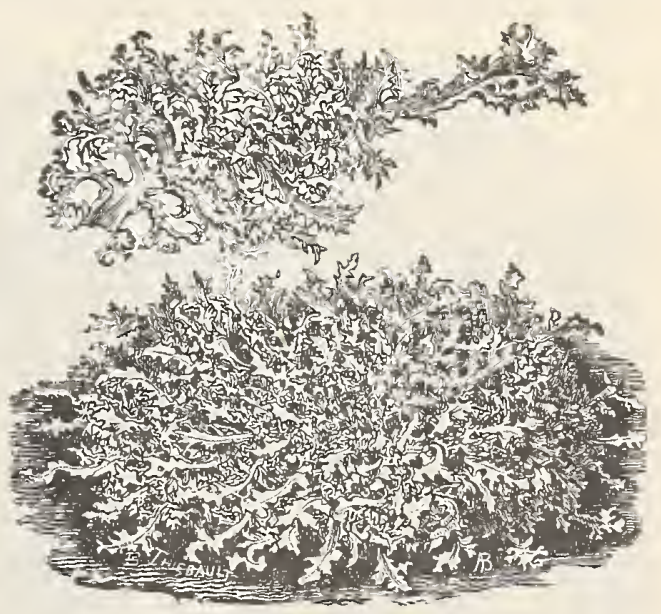

Green Curled Endive.

\section{Kohl=Rabi.}

One ounce will produce 2000 plants. Sow in rows in May or June, eighteen inches apart. thinning to eight inches between the plants.

Early White Vienna. This is the best and earliest var-

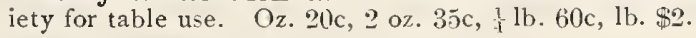

\section{Kale or Borecole.}

Sow from two to three pounds to the acre. Makes excellent greens for spring and winter use. Sow in September in drills or broadcast.

Dwarf German. (Curled.) Very hardy, leaves curled. Oz. 10c, 2 oz. 15c, 1. 1b. 20c, Ib. 50c. Tall Green Curled Scotch. Taller than the German. Oz. 10c, 2 oz. 20c, ${ }_{4}^{1}$ lb. $30 \mathrm{c}, 1 \mathrm{~b} . \$ 1$.

\section{Leek.}

One ounce will sow 100 feet drill. A hardy species of onion.

Large London Flag. Broad leaves, of strong and vigorous growth. Oz. 15c, $2 \mathrm{oz} .25 \mathrm{c}$, $\frac{1}{4} \mathrm{lb} .50 \mathrm{c}, \mathrm{lb} . \$ 1.50$.

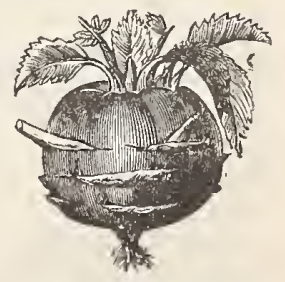

Early White Vienna Kohl-Rabi. 


\section{Lettuce.}

One ounce will produce 3000 plants. For early use sow under glass in January or early February, and transplant as soon as the ground can be nicely worked. Sowing may be made in the open ground from April to middle of August, every two or three weeks for succession.

Pkt. 5c, 3 pkts. $10 \mathrm{c}, \mathrm{r} / 2$ oz. $10 \mathrm{c}$, oz. $20 \mathrm{c}$, 2 oz. 35c, 1/4 lb. 50c, lb. $\$ 1.50$, postage paid, except where noted. If ordered by express, deduct $10 \mathrm{c}$ per $1 \mathrm{~b}$. from these prices.

Mammoth Black-Seeded Butter. A large variety. Heads solid, blanching to white at center. Leaves smooth, thick, brittle, tender and extra fine flavored.

California Cream Butter. A summer lettuce whose rich, cream-yellow leaves are most refreshing in appearance; rich and buttery to the taste. The heads are of good size, round and solid, and slow to go to seed.

Golden Queen. A splendid early lettuce, forming fine, hard heads of the best quality. One of the earliest heading sorts, and very popular for growing in frames, as on account of its small size it can be planted close.

New Sensation. One of the easiest to grow. Heads uniform and handsome. Splendid for summer use.

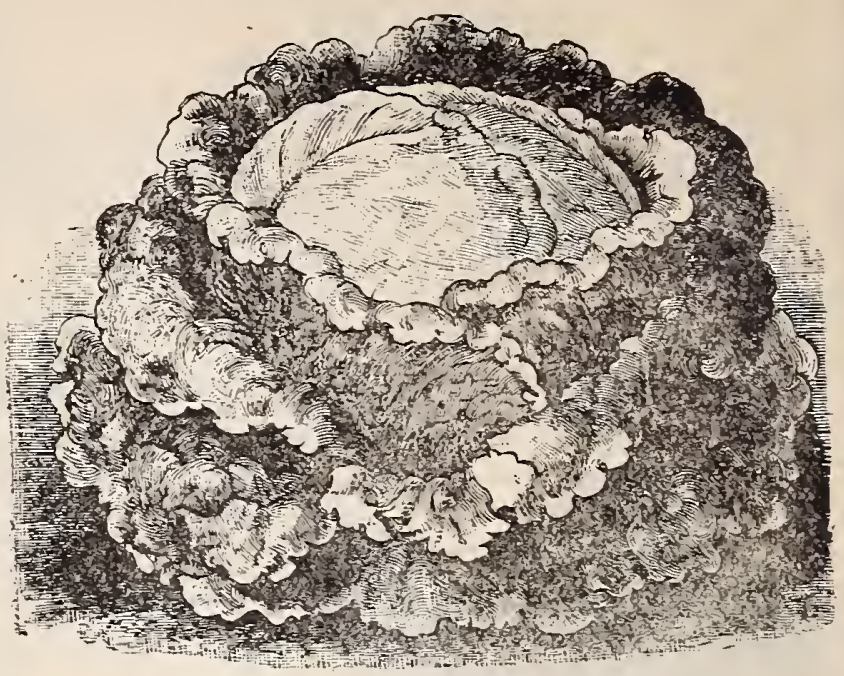

California Cream Butter Iettuce.

Hanson Lettuce. Plants large, forming a large, flat head resembling that of a cabbage. A good summer variety.

Hubbard's Market. Heads of good size, round and solid; outside medium green, within the leaves are a rich creamy yellow color.

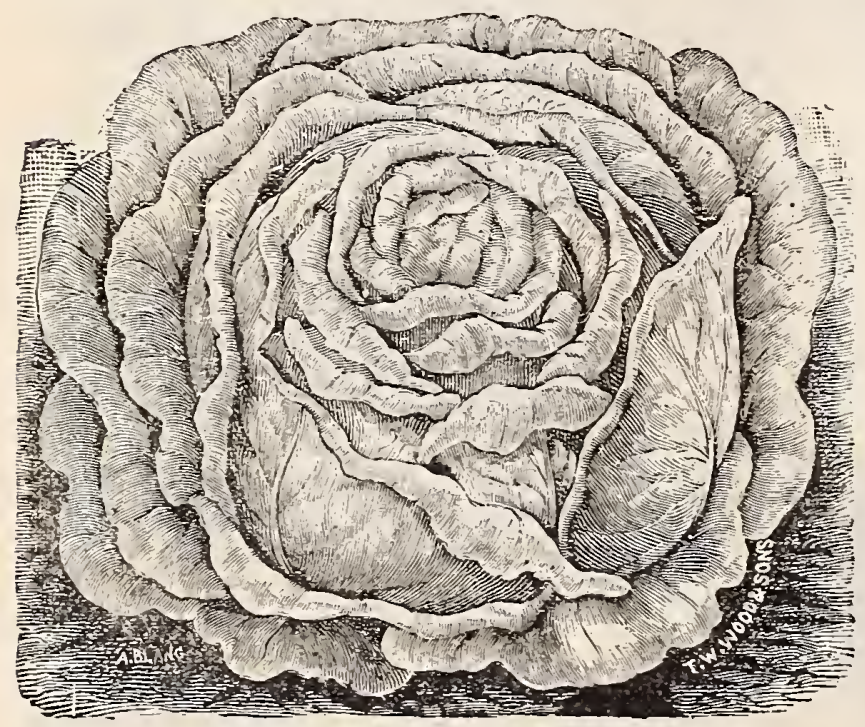

St. Louis Market. One of the best lettuces for all purposes. It cannot be recommended too highly. It will stand summer heat, and is slow in going to seed. Forms medium-sized heads, compact and solid. Leaves thick, rich and nutty in flavor. Our sales of this variety to market gardeners are constantly increas-

Trocadero. A distinct type of cabbage lettuce, heads of large size, very solid, and of a light green. They form very quickly, crisp, tender and exceedingly delicate in flavor.

Premium White Cabbage. An excellent variety, both for early use and for summer. It forms solid heads, crisp, tender and of the best quality.

New Mammoth Salamander. Grows to immense size, and stands to heat better than most any other kind.

Hardy Green Winter. One of the very best winter varieties; very hardy, and forms a solid head.

Mignonette. Heads very solid, outer leaves are richly covered with russet red and bronze green, while the solid hearts are of a light cream color.

St. Louis Market Lettuce.

Reichner's Early White Cabbage. A very attractive cabbage lettuce; large size, crisp and delicate in flavor, and very desirable for either winter or summer use, as well as for forcing. Forms a fine, large, solid head, and is remarkable for its fine foliage.

Schwill's Market Gardeners' Private Stock. Very large heads, resisting the sun a long time before running to seed.

White Cos Lettuce. Self-folding, delicate flavored, and resists the warm weather.

Iceberg. A fine variety; tender and free from any bitter taste. Makes good heads.

Large White Summer Cabbage. A bright green, vigorous, sure heading sort which forms a solid head of thick, tender leaves, the inner ones blanched to a beautiful crean yellow.

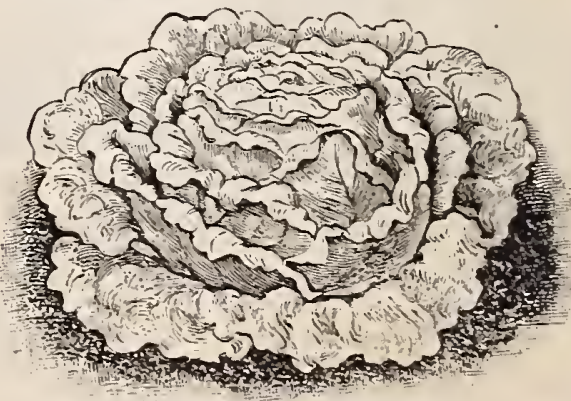

Reichner's Early White Cabbage Lettuce. 


\section{LETTUCE-Continued.}

Deacon. A large, solid cabbage lettuce for summer; heads light green, always good. A favorite with our market gardeners.

Wonderful Lettuce. Large, handsome heads; leaves slightly blistered, but very tender, and without any bitter taste whatever.

New York Head. Large, solid heads, dark green in color.

American Gathering. Twisted and curled leaves, fine for early and late sowing.

Yellow Seeded Butter. Dense yellow-heads, crisp and tender.

Big Boston. A very popular variety with gardeners who want a large heading, forcing sort, and also for out

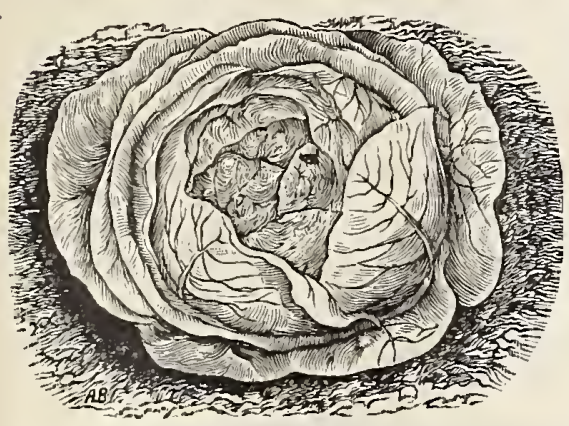

Big Boston Lettuce.

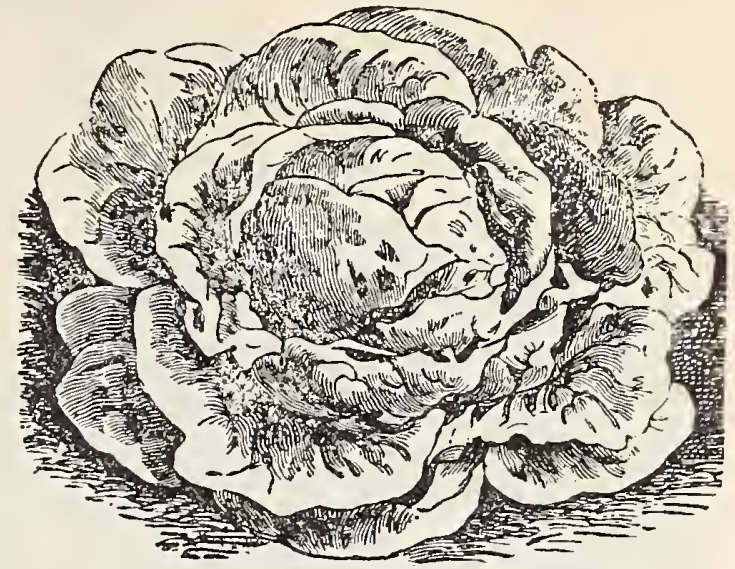

Deacon Lettuce. door winter culture. The plants are large, very hardy and vigorous. Indoors this forms a solid head, while outdoors it is less distinctly a heading sort.

Tennis Ball. Black seed ; forms close, hard heads, fine for forcing.

St. Louis Black Seed Forcing. Very large, solid heads, fine for forcing.

Brown Dutch. Fine for out door fall planting. Makes solid heads.

Simpson's Early Curled. An early, erect-growing, clustering variety; leaves frilled and blistered: Always tender and well flavored.

We can also supply the following well known lettuces at same prices as the foregoing: Prize Head, Black Seeded Simpson, Boston Market, Philadelphia White Cabbage.

Prices of all varieties of lettuce on this page are: Pkt. 5c, 3 pkts. 10c, 1/2 oz. 10c, oz. 20c, 2 oz. $35 \mathrm{c}$, $1 / 4 \mathrm{lb} .50 \mathrm{c}, \mathrm{lb} . \$ 1.50$, postage paid.

\section{SCHWILL'S CHOICE VEGETABLE PLANTS.}

\section{Well Grown and Lightly Packed to Carry Long Distances.}

The fact that these plants are all grown from choicest stocks of seed on our own grounds is sufficient recommendation as to the genuineness of the varieties. Sent by express only; purchaser to pay charges.

\section{CABBAGE PLANTS.}

\section{Ready March 1st.}

Early Jersey Wakefield.

Early Summer................................. .35

Succession

Early Flat Dutch..............................

Early Drumhead............. .35

Large Late Drumhead ......................... . .35

\section{CAULIFLOWER PLANTS.} Ready March 15th.

True Early Snowball.

.

Worldbeater.................................. .25

CELERY.

$$
\text { Ready A pril 15th. }
$$

Henderson's White Plume

Golden Self Blanching....................... .50

\section{EGG PLANT.}

Ready April 15th.

New York Improved Purple.

Doz.

LETTUCE PLANTS.

Ready March 15th.

St. Louis Market.

100

Large White Cabbage.......................... . .35

Schwill's Hard Head ......................... . .35

PEPPER PLANTS.

Ready April 15th.

Mammoth Sweet...

Doz.

Bell or Bull Nose.........

Ruby King .................................... .25

Long Red Cayenne ...................... . .25

TOMATO PLANTS.

1000
$\$ 2.50$
2.50
2.50
2.50
2.50
2.50
2.50

Per 100

$\$ .75$

.75

1000

$\$ 3.00$

3.00

100

$\$ 2.00$

1000

$\$ 2.50$

2.50

2.50

2.50

100

$\$ 1.50$

1.50

1.50

1.50
Ready March 15th. Hotbed 1000 Transplanted Strong Acme............. \$. $\$ 5 \$ .75 \$ 4.00 \$ .30 \$ 2.00 \$ 10.00$

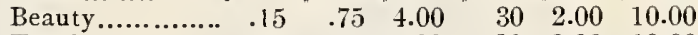

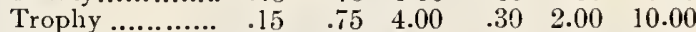

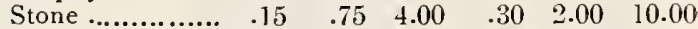

$\begin{array}{lllllll}\text { Ponderosa......... } & .15 & .75 & 4.00 & .30 & 2.00 & 1000\end{array}$

$\begin{array}{lllllll}\text { Imperial........... } & .15 & .75 & 4.00 & .30 & 2.00 & 10.00\end{array}$

$\begin{array}{lllllll}\text { Enormous.......... } & .15 & .75 & 4.00 & .30 & 2.00 & 10.00\end{array}$

$\begin{array}{lllllll}\text { Dwarf Champion } & .15 . & .75 & 4.00 & .30 & 2.00 & 10.00\end{array}$

\section{SWEET POTATO PLANTS.}

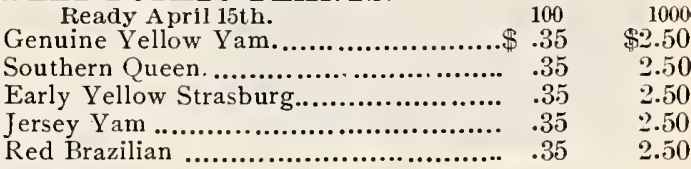

BUNCH YAII POTATO SLIPS.

Ready April 15th.

Bunch Yellow Yam $100 \quad \$ 000$

Spanish Bunch Yam....................... .50 3.50

Sage Plants.......................\$.10 $\quad$ Doz.

Thyme Plants.................... $10 \quad \$ \quad \$ .75$

Globe Artichoke Plants...... $.20 \quad 200$

Horse Radish Set............... $\quad .20$

Rhubarb Roots, Clump ........ .25 $\quad 1.50$

Chives or Schnittlauch, Clumps, each $25 \mathrm{c}$.

We do not send any vegetable plants by mail. They inust go by express al purchaser's expense. 


\section{Cantaloupe or Musk Melons.}

One ounce will plant about fifty hills, two pounds to the acre. The soil best adapted to the culture of melons is a warm, rich, sandy loam. Plant in hills five or six feet apart each way, ten or twelve seeds in a hill. IVhen they begin to vine, thin out, leaving only four of the most thrifty. As melons are very sensitive to cold, they should not be planted till the settled warm weather begins - in this latitude about the middle of April.

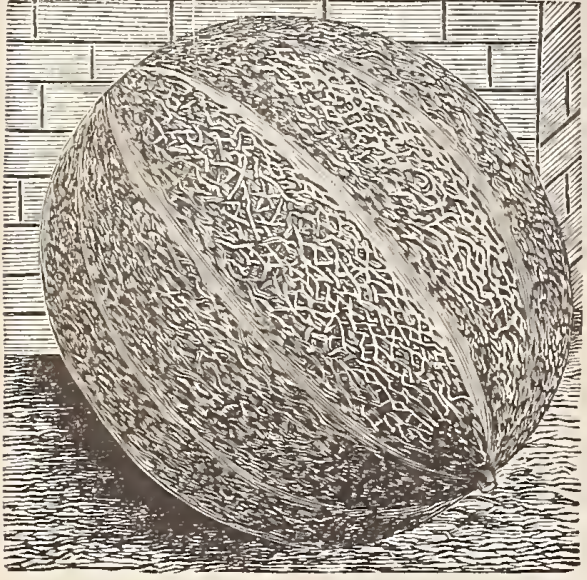

Early Netted Gem Cantaloupe.

Early Netted Gem. One of the earliest and the best small green-fleshed melon in cultivation. It is grown for shipping in baskets to almost every market in the country. The fruit, while not large, is remarkably uniform in size, globular in shape, skin light green and deeply netted. In flavor it is most delicious. Truly a gem. Pkt ăc, oz. 15c, 2 oz. 25c, $\frac{1}{1}$ lb. 35c, 1b. 90c, postpaid.

Paul Rose. A valuable melon for shipping in baskets. Fruit about five inches in diameter, nearly round. Solid with very small seed cavity. Flesh salmon color and of good quality. Pkt. 5c, oz. $15 \mathrm{c}, 2$ oz. $25 \mathrm{c}, \frac{1}{4} \mathrm{lb}$. $40 \mathrm{c}, 1 \mathrm{lb}$. $\$ 1.25$, postage paid.

Matthew's Prize Nutmeg. The flesh is thick, light green in color, and of rich, sweet flavor, well maintaining the promise of quality that is indicated by the deep ribs, heavy netting and handsome appearance. The melons are of the same form and outer appearance as Netted Gem, but are three times the size. Pkt. 5c, oz. 15c, 2 oz. 25c, $\frac{1}{4}$ lb. 40c, 1 lb. 51.25 , postage paid.

Emerald Gem. Small, extra early, dark green skin, orange flesh, very sweet. Pkt. 5̄c, oz. $15 \mathrm{c}, \underline{-2}$ oz. $25 \mathrm{c}, \frac{1}{4} \mathrm{lb} .4 \mathrm{fc}, 1 \mathrm{lb} . \$ 1.25$, postage paid.

Extra Early Hackensack. A desirable variety for early use, matures only a few days later than the Netted Gem but is much larger, good quality. Pkt. 5c, oz. 15̄c, 2 oz. $25 \mathrm{c}, \frac{1}{4} 1 \mathrm{~b} .35 \mathrm{c}, 1 \mathrm{lb}$. $\$ 1$, postage paid.

Improved or Large Baltimore. We offer true home-grown seed of this excellent variety; a market favorite, with its fine, large and perfect shape and excellent quality. No grower should be without it. On the market it always sells for double the price of most all other sorts. Plit. j̄c, oz 20c, 2 oz. 30c, 光 lb. 50c, 1 lb. \$1.50.

Champion Market. Green flesh, medium size, very early, fine for market, skin roughly netted. Pkt. 5c, oz. 15c, 르 oz. $25 \mathrm{c}, \frac{1}{4}$ lb. $35 \mathrm{c}, 1 \mathrm{lb} . \$ 1$, postage paid.

Prolific Netted Nutmeg. Medium size, of highest flavor, the perfect shaped melons are densely netted, slightly ribbed and a farorite with most everyone. Pkt. 5c, oz. 15c, 2 oz. 25c, $\frac{1}{4} \mathrm{lb} .35 \mathrm{c}$, $1 \mathrm{lb} . \$ 1$, postage paid.

New Orleans Market. A truly Southern melon, largely grown for the New Orleans market, where it commands the highest price.

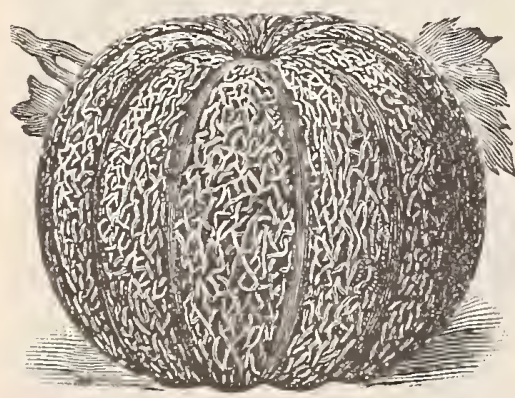

Prolific Netted Nutmeg Cantaloupe.

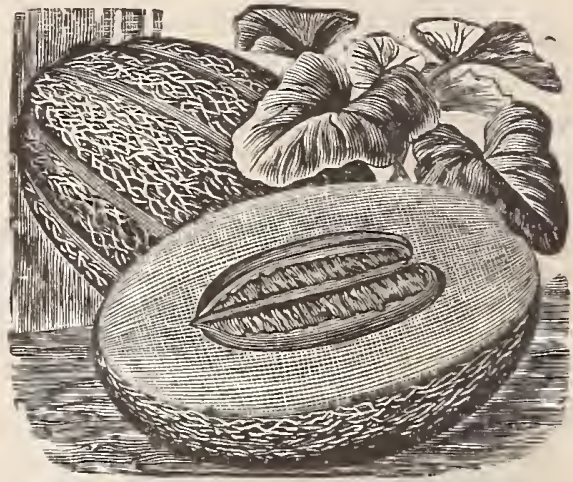

Baltimore or Acme Cantaloupe. ly netted, and of a delicious flavor. This variety should become one of our most popular sorts, both for table and market. Pkt. 5c, oz. 15̄c, 2oz. 25̄c, 1b. $40 \mathrm{c}, 1 \mathrm{lb}, \$ 1.25$, postage paid.

Baltimore or Acme. Oval shape, green flesh, of good size, heavily netted. one of the good ones for marliet, largely planted. Pkt. ác, oz. 15x, 2 oz. 25̄c, $\frac{1}{4}$ lb. $40 \mathrm{c}, 1 \mathrm{lb} . \$ 1$, postage paid.

Montreal Market. Very large size, covered with dense netting, flesh green, thick and very sweet. If you are partial to large melons plant the Montreal Market. Pht. 5c, oz. 15c, 2 oz. $25 \mathrm{c}, \frac{1}{4} \mathrm{lb} .35 \mathrm{c}, 1 \mathrm{lb} . \$ \mathrm{I}$, postage paid.

". There is a touch of flavor in the garden truck that nobody ever finds, except the man who swings the hoe."

\section{STRAWBERRY COLLECTION.}

\section{$\$ 3.50-$ One Thousand Strawberry Plants, Express Prepaid $-\$ 3.50$}

Upon receipt of $\$ 3.50$ we will send you the following five splendid varieties of Strawberry Plants-one thousand in all. Having a surplus in these, we cannot allow any change in variety: 


\section{Watermelons.}

One ounce to forty hills, three to four pounds in hills to the acre. Drop in the middle of spring, in hills six to eight feet apart, six to ten seeds, one inch deep, and thin to three best plants. Generally about the middle of April is the proper time to plant melons in this section.

$5 \mathrm{c}$ per packet, or 3 packets for $10 \mathrm{c}$, any variety, postpaid, except where noted otherwise.

Alabama Sweet. Southern grown seed; one of the best and sweetest Havored varieties in existence; dark green, thin rind; flesh scarlet, solid, firm and luscious in quality; it's a good one. Oz. $20 \mathrm{c}, 2$ oz. $35 \mathrm{c}, \frac{1}{1 \mathrm{l}} \mathrm{b} .50 \mathrm{c}, 1 \mathrm{~b} . \$ 1.50$.

The Eden. Southern grown seed; similar in shape and appearance to the Kolb Gem; a strong, vigorous grower, immensely productive. $\mathrm{Oz} .15 \mathrm{c}$, 2 oz. 25 c, $\frac{1}{4}$ lb. 40 c, lb. $\$ 1.00$.

The Bradford. Southern grown seed. This Melon is the favorite, above all others, in South Carolina; grows to a large size, and very prolific; rind is medium thick and tough, dark green, with darker stripe; flesh is red, remarkably tender and sweet. Oz. 15c, 2 oz. 30c, $\frac{1}{4}$ lb. 50c, lb. \$1.25.

Genuine Augusta Rattlesnake. Southern grown seed. Our strain is the result of careful selection by an experienced melon grower through several years of careful and watchful work. The rind is thin and tough, and the flesh deep scarlet; the flavor is unsurpassed by any other sort. Oz. $15 \mathrm{c}, 2 \mathrm{oz} .25 \mathrm{c}, \frac{x}{4} \mathrm{lb} .35 \mathrm{c}, \mathrm{lb} . \$ 1.00$, postage paid.

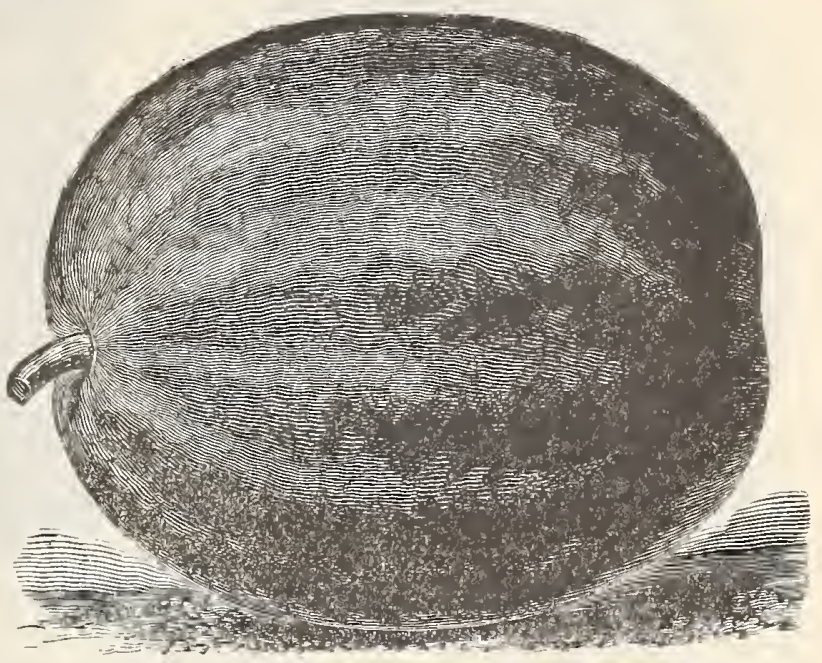

The Eden.

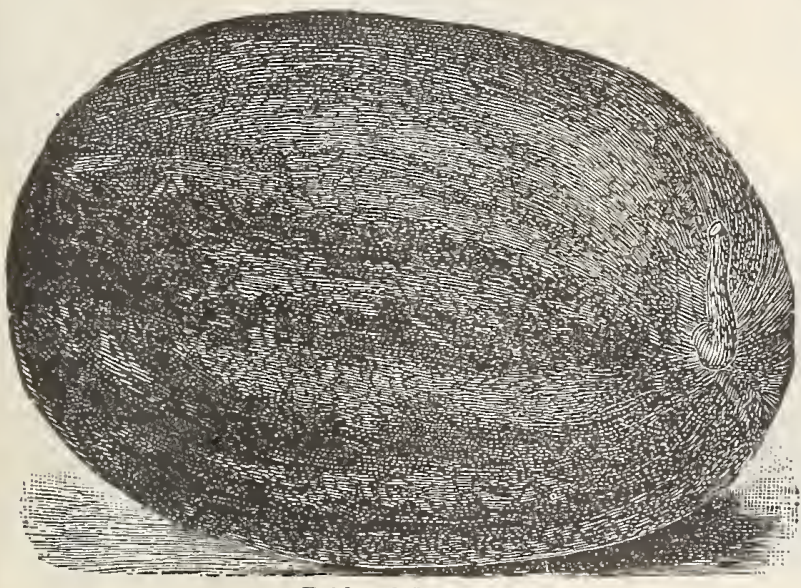

Pride of Georgia.

Florida Favorite. A very large, long Melon, mottled dark green, with stripes of lighter shade; rind thin but firm, flesh very bright deep red, very sweet, tender and excellent. Oz. 10c, $2 \mathrm{oz} .15 \mathrm{c}, \frac{1}{4} 1 \mathrm{~b} .25 \mathrm{c}$, Ib. $75 \mathrm{c}$.

Arkansas Traveler. Ripens in 75 days; a large, long, weighty Melon; rind dark green, almost black; flesh brilliant red, sweet, tender, crystalline and very juicy; altogether very superior; rind is very thin but tough, making it a splendid keeper. Oz. 20c, 2 oz. 35c, $\frac{1}{4} 1 \mathrm{~b}$. $60 \mathrm{c}, 1 \mathrm{~b} . \$ 2.00$.

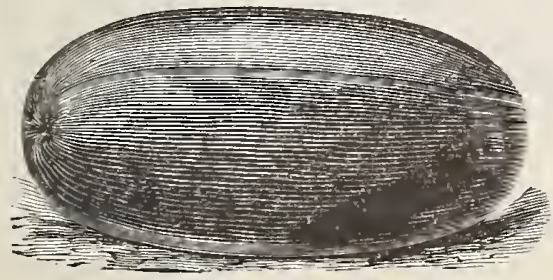

Florida Favorite.
Joe Johnson. Southern grown seed. An old favorite, which makes friends wherever grown; the melons run very uniform in size, with very few culls ; excellent for market, shipping and home use. Oz. 15 c, 2 oz. 30c, $\frac{1}{4}$ lb. 50c, 1b. $\$ 1.25$.

The Jones. Southern grown seed. One of the best all-around melons on our list; often attains a weight of sixty to seventy pounds; solid green rind, flesh bright red and very sweet and juicy. Ounce $15 \mathrm{c}, 2$ oz. $25 \mathrm{c} .1 \mathrm{lb} .35 \mathrm{c} .1 \mathrm{~b} . \$ 1.00$.

Grist, or Benjestown. Southern grown seed. Also called by some The Gray Kid. We have the pure home-grown seed of this splendid variety; the fruit is very large and solid, and the flesh is bright red and always sweet. Ounce $20 \mathrm{c}$, 2 ounce $35 \mathrm{c}$, $\$$ pound $50 \mathrm{c}$, pound $\$ 1.50$, postage paid.

Pride of Georgia. Southern grown seed; very large and heavy, and a splendid shipper; flesh is blood red and exceedingly sweet. Oz. 10c, $2 \mathrm{oz}$. $20 \mathrm{c}, \frac{1}{4} \mathrm{lb} .30 \mathrm{c}, \mathrm{lb} . \$ 1.00$, postage paid.

Cuban Queen. Solid and heavy; flesh dark red; extremely early. Ounce $10 \mathrm{c}, 2$ ounce $15 \mathrm{c}$, $\frac{1}{4}$ pound $25 \mathrm{c}$, pound $75 \mathrm{c}$.

Duke Jones. Large, handsome, dark green red flesh and fine flavor. Ounce $10 \mathrm{c}, 2$ ounce $15 \mathrm{c}$, $\$$ pound $25 \mathrm{c}$, pound $75 \mathrm{c}$.

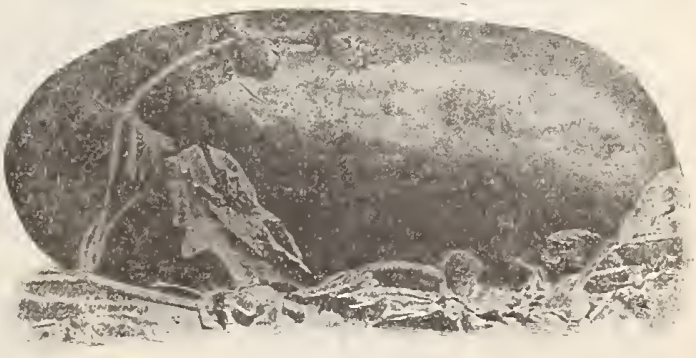

The Bradford. 
WATERMELONS-Continued.

Fordhook Early. The largest of the extra early watermelons. Shape nearly round; color is medium green, rind tough, flesh bright red, and is very delicate, melting and deliciously sweet. Ounce 10c, 2 ounce $15 \mathrm{c}$, $\frac{1}{4}$ pound $25 \mathrm{c}$, pound $85 \mathrm{c}$, postage paid.

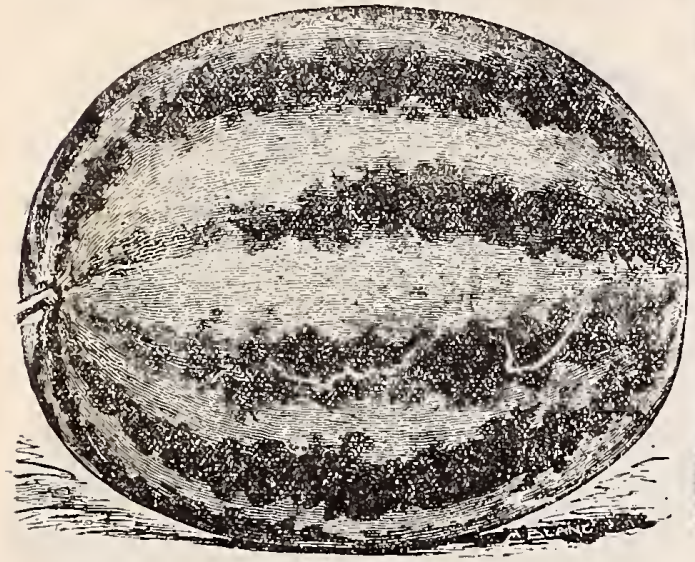

Kolb's Gem.

Kolb's Gem. The flesh is bright red and of good flavor. It is one of the largest melons grown in this section of the country, weighing from thirty to fifty pounds, and is a most productive and the best keeping melon handled by us Our stock cannot be surpassed. Every watermelon grower should try it. Oz. $10 \mathrm{c}, 2$ oz. 15c, $\frac{1}{4} \mathrm{lb} .25 \mathrm{c}, 1 \mathrm{~b} .75 \mathrm{c}$, postage paid.

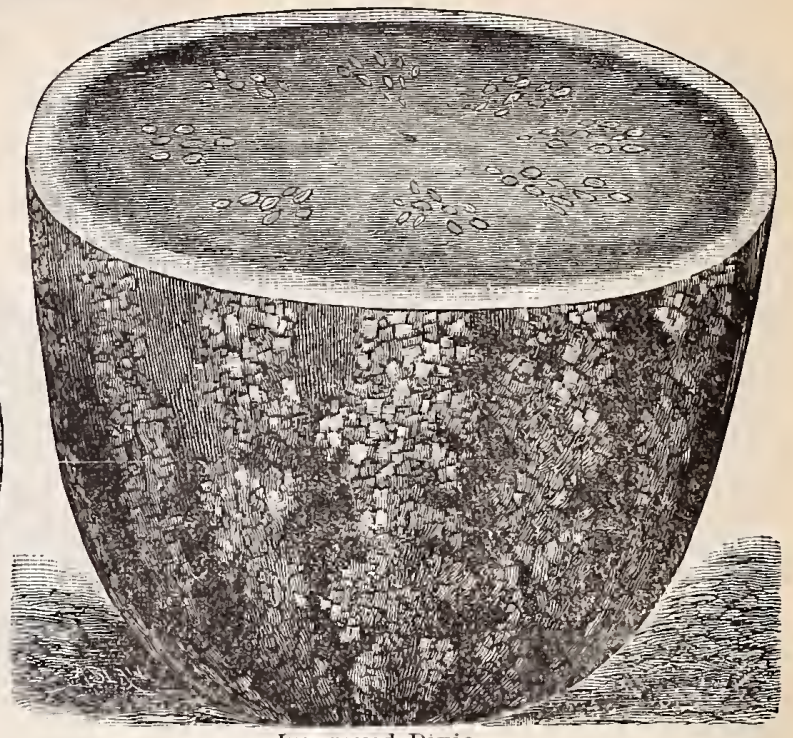

Improved Dixie.

McIver's Wonderful Sugar. Oblong in shape, and of handsome appearance; quality very superior and exceedingly sweet. The flesh is a pale pink, crisp and free from any stringiness whatever. The melons have a solid heart, free from any cracks, and the seed rows are close to the rind. Ounce $10 \mathrm{c}, 2$ ounce $15 \mathrm{c}$, ${ }_{4}^{1}$ pound $25 \mathrm{c}$, pound $85 \mathrm{c}$, postage paid.

Georgia Rattlesnake. Oblong, dark and striped; bright red flesh, which is exceedingly sweet. Oz. $10 \mathrm{c}, 2 \mathrm{oz} .15 \mathrm{c}, \frac{\pi}{4} \mathrm{lb} .25 \mathrm{c}, \mathrm{lb} .75 \mathrm{c}$.

Sweet Heart. A magnificent melon; vine vigorous and productive, ripening fruit early; fruit large, oval, very heavy, uniformly mottled light and very light green; rind thin but firm; flesh bright red, firm, solid, tender, melting and sweet. Oz. $10 \mathrm{c}, 2 \mathrm{oz} .15 \mathrm{c}, \frac{1}{4} \mathrm{lb} .25 \mathrm{c}, 1 \mathrm{~b} .75 \mathrm{c}$.

Improved Dixie. A popular sort; fruit is medium sized to large, and color of skin dark green, striped with a lighter shade; rind thin but tough; flesh bright scarlet; ripens closely to the rind. Ounce $10 \mathrm{c}, 2$ ounce $15 \mathrm{c}$, $\frac{1}{4}$ pound $25 \mathrm{c}$, pound $75 \mathrm{c}$, postage paid.

McIver's Wonderful sugar.

Jordan's Gray Monarch. The skin is of an attractive, mottled, very light green color, so light as to nearly warrant the name white or gray. The flesh is of a deep red color, and of very fine quality; fully equal to the old Round Icing, which has long been recognized as one of the finest flavored watermelons grown. Ounce $10 \mathrm{c}, 2$ ounce $15 \mathrm{c}$, $\frac{1}{4}$ pound 2.5 c, pound săc.

The following well-known varieties we will supply at a uniform price of $5 \mathrm{c}$ per packet, 3 packets for $10 \mathrm{c}$, ounce $10 \mathrm{c}, 2$ ounce $15 \mathrm{c}$, ${ }_{4}^{1}$ pound $25 \mathrm{c}$, pound $75 \mathrm{c}$, postage paid :

True Ice Cream. Mammoth Ironclad. Mountain Sprout. Early Peerless. Mountain Sweet. Jones' Jumbo.

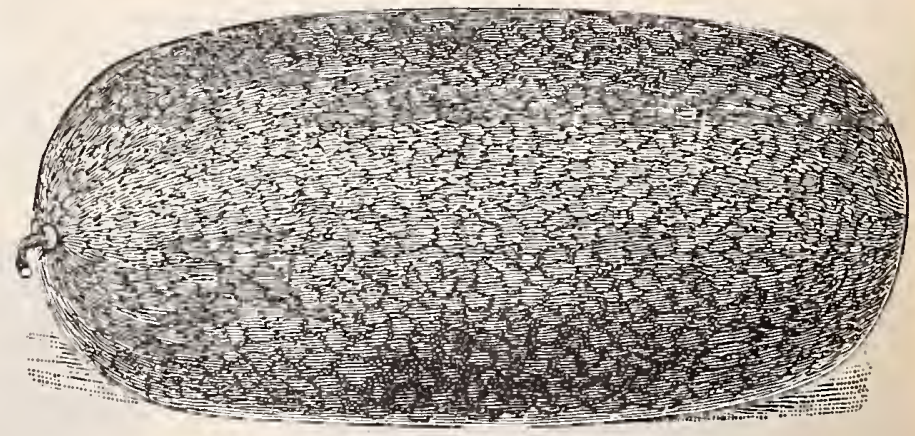

Jordan's Gray Monarch. 


\section{Onions.}

Onion seed should be sown as soon as possible in the spring even if the weather is cold, so the soil works up well. This gives them a good start ahead of the weeds, and before dry weather sets in. After thoroughly pulverizing the soil, sow thinly, four to five pounds to the acre, in drills about one foot apart and about one-fourth inch deep, in strong land, well manured. When well started, say about four inches high, thin out to stand three or four inches apart in drills, keeping them well hoed and free from weeds.

Prizetaker. An excellent keeper, of finest flavor, handsome shape and enormous size, many single onions having been raised to weigh five pounds and over from seed the first year. It is of the same type as those immense imported onions, which can be seen in fruit stores, and always command a very high price. The Prizetaker grows always to a perfect globe shape, with a bright straw-colored skin, the neck is very small and the onions always ripen up hard. $\mathrm{Oz} .20 \mathrm{c}, 2 \mathrm{oz} .30 \mathrm{c}$, $\frac{1}{4} \mathrm{lb} .50 \mathrm{c}, 1 \mathrm{~b} . \$ 1.80$, postage paid.

Large Red Globe. A large, red, globe-shaped variety, and the best keeper. Oz. 15c, 2 oz. $25 \mathrm{c}, \frac{1}{4}$ lb. $40 \mathrm{c}, 1 \mathrm{~b} . \$ 1.25$.

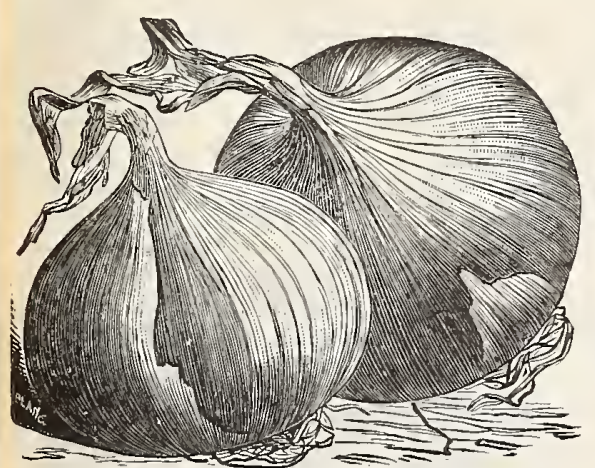

Large Yellow Globe Danvers Onion.

Large Yellow Globe Danvers. A standard sort, grows to a large size. Oz. 15c, 2 oz. $25 \mathrm{c}, \frac{1}{4}$ lb. $40 \mathrm{c}, 1 \mathrm{~b} . \$ 1.25$.

Large Red Wethersfield. One of the best large red varieties, good keeper, matures very early. Oz. 15c, $2 \mathrm{oz}$. 25c, 1b. $\$ 1.15,5 \mathrm{lbs}$. $\$ 5$, postage paid.

Red Globe Wethersfield. Matures ten days earlier than Southport Red Globe; in shape and size, it is far superior to the ordinary Red Wethersfield, making it one of the most desirable on our list. Oz. 20c, 2 oz. 30c, $\frac{1}{4} \mathrm{lb} .50 \mathrm{c}, 1 \mathrm{~b} . \$ 1.50$, postage paid.

Extra Early Pearl. The earliest and best of all American varieties. It is of good size, of pearly white color, the outer skin having a most showy, waxy appearance; flesh is pure snow white, and flavor so mild that it can be eaten like an apple. Oz. $25 \mathrm{c}, 2 \mathrm{oz} .40 \mathrm{c}, \frac{1}{4} \mathrm{lb} .75 \mathrm{c}$, lb. $\$ 2.50$.

Red Bermuda. Of a rich blood red color, fine grained, mild and pleasant. Oz. 25c, 2 oz. 40c, $\frac{1}{4}$ lb. 75 c, lb. $\$ 2.25$.

White Bermuda. Very large and it is of attractive shape, with a very white skin. Oz. $25 \mathrm{c}, 2 \mathrm{oz} .40 \mathrm{c}, \frac{1}{4} \mathrm{lb}$. $75 \mathrm{c}, \mathrm{lb} . \$ 2.50$.

White Marzajola, or May Onion. One of the earliest of all, fine for bunching. $\mathrm{Oz} .20 \mathrm{c}, 2 \mathrm{oz} .35 \mathrm{c}, \frac{1}{4} \mathrm{lb}$. $60 \mathrm{c}, 1 \mathrm{~b} . \$ 2.25$.

Silver White Skin. A silvery white onion, of handsome appearance. Oz. 20c, 2 oz. $35 \mathrm{c}, \frac{1}{4} \mathrm{lb} .50 \mathrm{c}, 1 \mathrm{~b} . \$ 1.75$.

White Portugal. Ripens early, of large size, mild in flavor, much esteemed for pickling when small, and grows a handsome big onion. Oz. $20 \mathrm{c}, 2 \mathrm{oz} .35 \mathrm{c}, \frac{1}{4} \mathrm{lb} .50 \mathrm{c}, 1 \mathrm{~b} . \$ 1.75$.

Italian Dark Red. A popular and well known deep blood red onion, used largely by our gardeners. A beautiful dark red skin; flesh mild and pleasant. Oz. 25c, 2 oz. $40 \mathrm{c}, \frac{1}{4}$ lb. $60 \mathrm{c}, 1 \mathrm{~b} . \$ 2$.

All varieties 5c per packet or 3 for $10 \mathrm{c}$.
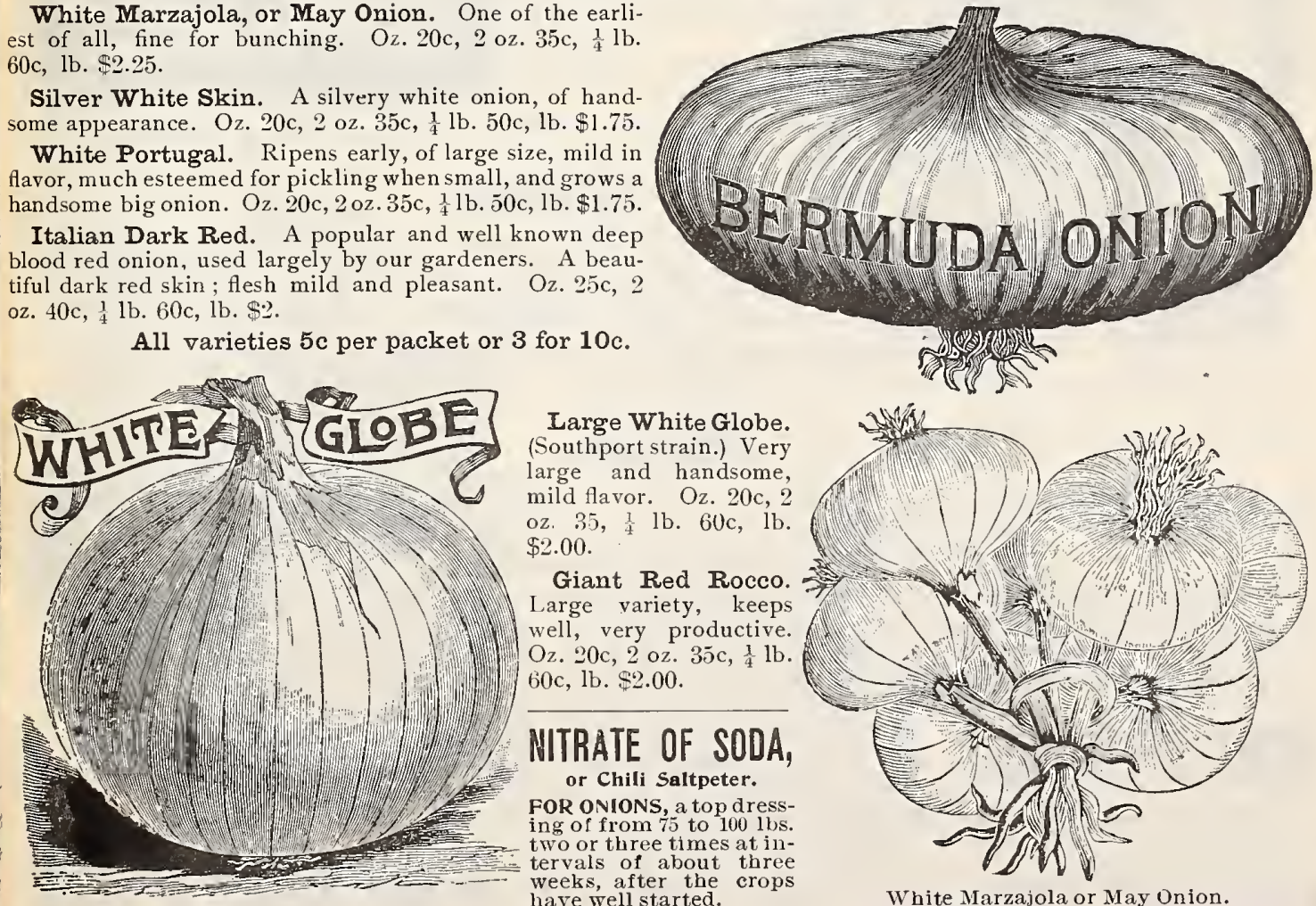

Large White Globe. (Southport strain.) Very large and handsome, mild flavor. Oz. $20 \mathrm{c}, 2$ oz. $35, \frac{\pi}{4}$ lb. $60 \mathrm{c}, 1 \mathrm{~b}$. $\$ 2.00$.

Giant Red Rocco. Large variety, keeps well, very productive. $\mathrm{Oz} .20 \mathrm{c}, 2$ oz. $35 \mathrm{c}, \frac{1}{4} \mathrm{lb}$. $60 \mathrm{c}, \mathrm{lb} . \$ 2.00$.

NITRATE OF SODA, or Chili Saltpeter.

FOR ONIONS, a top dressing of from 75 to $100 \mathrm{lbs}$. two or three times at intervals of about three weeks, after the crops have well started.

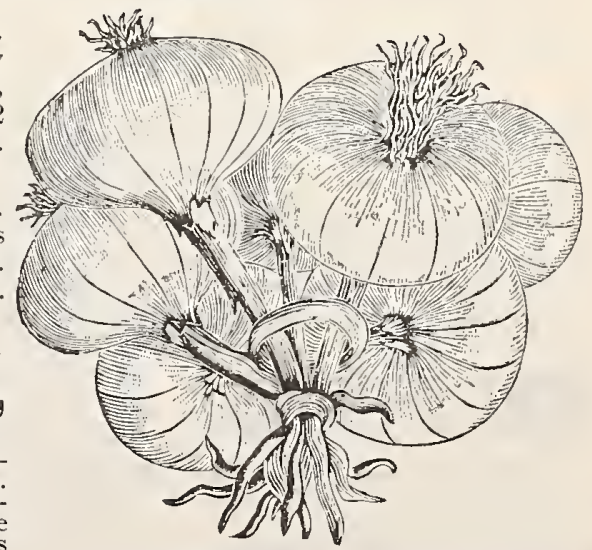

White Marzajola or May Onion. 


\section{Onion Sets.}

One quart to twenty feet of drill; six to eight bushels, depending on size, to set an acre in drills. Prices are based on the present market rates, and are subject to change according to the market, without notice. Lowest market prices on small or large quantities will be given on application at any time. At bushel, peck and half peck prices, the buyer pays the express or freight; at pint and quart prices we pay the postage. Bottom Sets and Potato Onions are sold by the measure; White Multiplier and Egyptian by weight, twenty-eight pounds for a bushel.

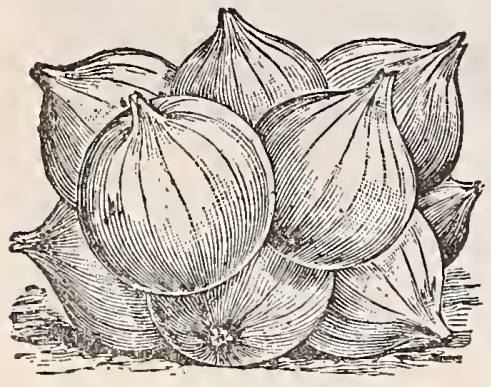

White Multiplier Onion Sets.

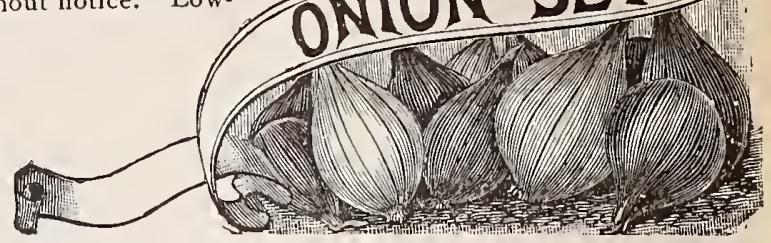

White Multiplier Sets. This new multiplying variety is very hardy, enormously productive and handsome in appearance. As many as twenty sets have been counted on a single bunch. Qt. 30c, postage paid; by express or freight, $\frac{1}{2} \mathrm{pk} .75 \mathrm{c}, \mathrm{pk}$. $\$ 1.25$, bu. $\$ 3.50$.

\begin{tabular}{|c|c|c|c|c|}
\hline \multirow[b]{2}{*}{ Onion Sets. } & \multirow{2}{*}{$\begin{array}{c}\text { By Mail } \\
\text { Postpaid } \\
\text { Qt. }\end{array}$} & \multicolumn{3}{|c|}{ By Express or Freight } \\
\hline & & $\begin{array}{l}1 / 2 \\
\text { Pk. }\end{array}$ & $\begin{array}{c}\text { aser's } \\
\text { Pk. }\end{array}$ & $\begin{array}{l}\text { ense } \\
\text { Bu. }\end{array}$ \\
\hline Yellow &..$\$ .25$ & & $\$ .60$ & $\$ 2.00$ \\
\hline Dark Red & $\ldots \quad .25$ & .40 & .75 & 2.25 \\
\hline White............. & .25 & .40 & .75 & 2.50 \\
\hline 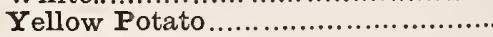 & .30 & .60 & 1.00 & 3.25 \\
\hline White Multiplier........................ & .30 & .75 & 1.25 & 3.50 \\
\hline yptian Tree.......................... & .25 & .40 & .70 & 2.00 \\
\hline
\end{tabular}
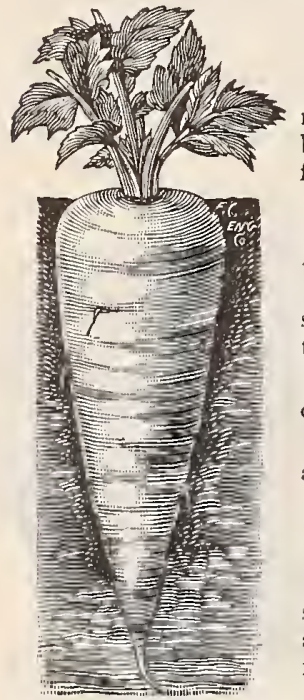

Sugar or Hollow Crown Parsnip.

\section{Okra.}

One ounce will plant 100 hills. In mild climate plant late in spring, after the ground has become warm, in hills about two and one-half feet apart, and thin to three plants in a hill.

Pkt. 5c, 3 Pkts. 10c, oz. 10c, 2 oz. 15c, $1 / 4$ lb. 20c, 1b. 60c, any variety.

White Velvet Pod. A beautiful, prolific, smooth, round pod Okra. It is exceedingly tender and well flavored.

Tall, or Long Green. Pods long, slender, dark green, tender, high flavor.

Early Dwarf Green. Early; pods short and very numerous.

\section{Parsnip.}

One ounce will sow 200 feet or drill, five pounds required for one acre. As the seed is sometimes slow to germinate, it should be sown as early as possible in drills two feet to two and one-half feet apart; cover one-half inch deep, and press the soil firmly over the seed. Give frequent cultivation, and thin the plants to five or six to the foot.

Sugar, or Hollow Crown Parsnip. Roots very long, white, smooth, tender, sugary, and of most excellent flavor. Pkt. 5c, oz, 10c, $2 \mathrm{oz}, 15 \mathrm{c}, \frac{1}{4} \mathrm{lb}, 20 \mathrm{c}, 1 \mathrm{~b} .50 \mathrm{c}$.

\section{Mustard.}

One ounce will sow about eighty feet of drill. For early salad sow in February, and for general crop at intervals through the spring, in rows six inches apart, and rather thick in rows.

\section{Pkt. 5c, 3 pkts. 10c, any variety.}

Ostrich Plume. A most beautiful mustard. Leaves are tender, very long and finely crimped. Pretty as an ornamental plant, looks like ostrich plumes. A must perfect mustard. Oz. 15c, $2 \mathrm{oz} .25 \mathrm{c}, \frac{1}{4} \mathrm{lb} 40 \mathrm{c}, 1 \mathrm{~b} .90 \mathrm{c}$.

Southern Giant Curled. True curled leaf, forms enormous bunches. Oz. 10c, 2 oz. 15c, $\frac{1}{4} \mathrm{lb} .20 \mathrm{c}, \mathrm{lb} .60 \mathrm{c}$.

White London-Black or Brown. Both well known varieties, much used. Oz. $5 \mathrm{c}, \frac{1}{4} 1 \mathrm{~b} .15 \mathrm{c}, 1 \mathrm{~b} .3 \mathrm{~s} \mathrm{c}$, postpaid.

A nice little machine which has been tested in all parts of the United States. It will sow beet, cabbage, carrot, celery, lettuce, radish, turnip and all such seeds with perfect regularity. It is simple in construction, and by its use you will save time, save seed, make the work easier, and get a better stand. If a longer handle is desired, it can easily be attached, but are made short for convenience in shipping. Price $\$ 1$ each. 


\section{Parsley.}

One ounce will sow 150 feet of drill. Sow early in the spring in drills a foot apart. The seed germinate very slowly, and sometimes two or three weeks will elapse before the plants will make their appearance. It of ten fails entirely in dry weather.

Pkt. 5c, 3 pkts. $10 \mathrm{c}$.

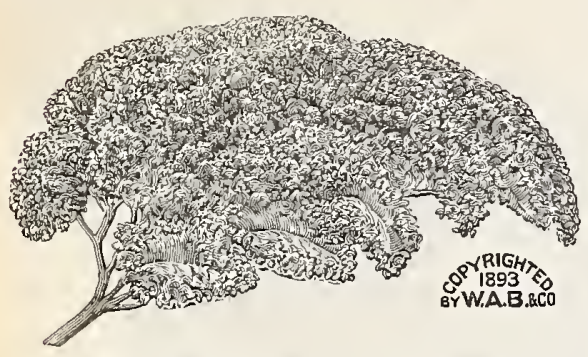

Extra Park Moss Curled Parsley.
Curled or Doubled. Leaves crimped or curled, used principally as a garnish for the table. Oz. $10 \mathrm{c}$, $2 \mathrm{oz} .15 \mathrm{c}, \frac{1}{4} \mathrm{lb} .20 \mathrm{c}, \mathrm{lb} .60 \mathrm{c}$.

Extra Dark Moss Curled. Beautifully curled and crimped, and extra dark green color. $\mathrm{Oz} 10 \mathrm{c}$, $2 \mathrm{oz}, 15 \mathrm{c}, \frac{1}{4} \mathrm{lb} .25 \mathrm{c}, \mathrm{lb} .75 \mathrm{c}$.

Plain or Single. Dark green, better flavored for seasoning. Oz. 10c, $2 \mathrm{oz}$. $15 \mathrm{c}, \frac{1}{4} 1 \mathrm{~b} .20 \mathrm{c}, \mathrm{lb} .50 \mathrm{c}$.

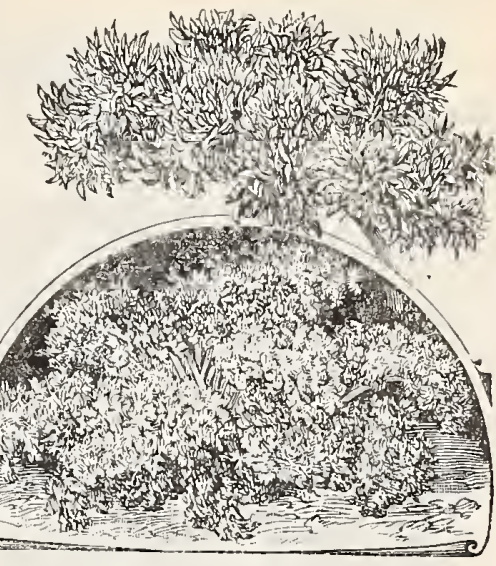

Double Curled Parsley.

\section{Pepper.}

One ounce will produce 1000 plants. Sow early in spring in hotbed, and transplant to the open ground as soon as the weather is warm and settled. The seed may also be sown in the open ground but not until all danger of frost is past.

Sweet Mountain. It is a strong grower, very productive, and of excellent quality. The peppers when young are of a bright deep green color, without any shade of purple; when ripe, they are of a beautiful red. The flesh is thick, sweet and mild. They of ten grow six inches long by four inches through. Our strain has been selected with great care, and we know no better seed can be had. Pkt. 5c, $\frac{1}{2}$ oz. $15 \mathrm{c}$, oz. $25 \mathrm{c}, 2 \mathrm{oz} .45 \mathrm{c}$.

Ruby King. These are of a bright ruby red color, remarkably mild and pleasant. Can be sliced and eaten with vinegar and pepper, used as a salad or stuffed as mangoes. The fruit is from four to six inches long. Pkt. $5 \mathrm{c}, 1 \frac{1}{2} \mathrm{oz} .15 \mathrm{c}, \mathrm{oz} .25 \mathrm{c}, 2 \mathrm{oz} .45 \mathrm{c}$.

Large Bell, or Bull Nose. Of large size; flesh thick and pungent. Pkt. 5c, $\frac{1}{2}$ oz. $10 \mathrm{c}$, oz. 20c, 2 oz. $35 \mathrm{c}$.

Red Chili. Very productive, very small, red and very pungent. 1'kt. 5c, oz. $30 \mathrm{c}$.

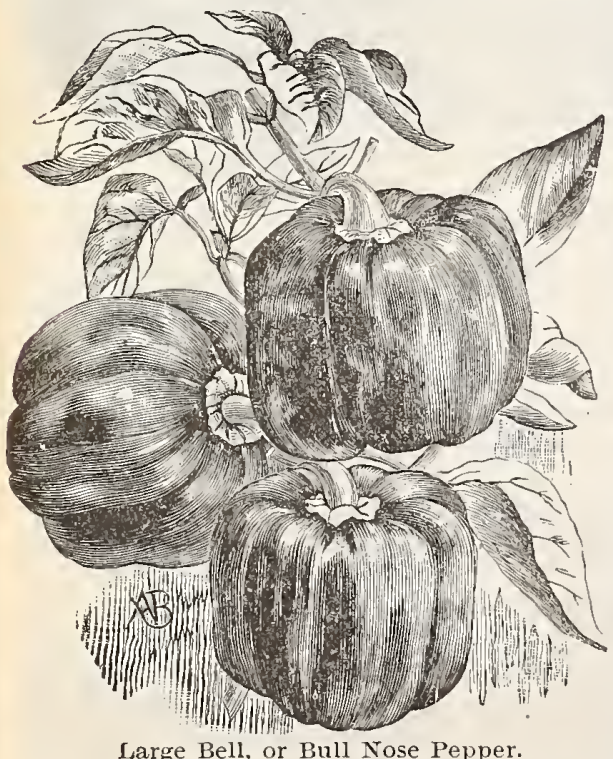

Long Red Cayenne. Grows about four inches long. Color bright red, strong. Pkt. 5c, $\frac{1}{2} \mathrm{oz} .15 \mathrm{c}, \mathrm{oz}$. $25 \mathrm{c}, 2 \mathrm{oz} .45 \mathrm{c}$.

To bas co. Bush two feet high; small, long, bright red fruits in clusters; very hot, and the best for peppersauce and pickling. Pkt. $10 \mathrm{c}, \mathrm{oz} .50 \mathrm{c}$.

\section{Pumpkin.}

Tennessee Sweet Potato. A heavy cropping sort. Excellent for table or stock. Oz. 10c, 2 oz. $15 \mathrm{c}, \frac{1}{4} \mathrm{lb} .25 \mathrm{c}, 1 \mathrm{~b} .85 \mathrm{c}$.

Cushaw, or Crook Neck. Most popular. Splendid for table or stock. Flesh light cream color, solid and sweet. $\mathrm{Oz} .10 \mathrm{c}, 2 \mathrm{oz}$. $15 \mathrm{c}, \frac{1}{4} \mathrm{lb} .25 \mathrm{c}, 1 \mathrm{~b} .85 \mathrm{c}$, postage paid.

Michigan Mammoth. Grows to an immense size. Oz. 10c, 2 oz. ]5c, $\frac{1}{4} 1 \mathrm{~b} .25 \mathrm{c}, \mathrm{lb} .90 \mathrm{c}$.

Kentucky Large Yellow. Large and productive. Flesh yellow, thick, tender and nutritious and of fine quality. Pt. 20c, qt. $35 \mathrm{c}$, postage paid; by express, qt. $30 \mathrm{c}, \frac{1}{2} \mathrm{pk} . \$ 1$, bu. $\$ 5.50$. 


\section{SEED POTATOES.}

Ten bushels cut tubers will plant an acre. The potato requires a rich, sandy loam with very liberal and clean culture; thoroughly decomposed manure is the best. A mixture of cotton seed meal and our acid phosphate with potash, about half and half, makes the best fertilizer for the spring crop of potatoes. Do not fail to try this formula. For a second or fall crop plant during August any time, even as late as September first will do.

We quote the following varieties subject to change of market. Write for our special figures on lots before buying elsewhere. We make a specialty of seed potatoes, and know we can please you.

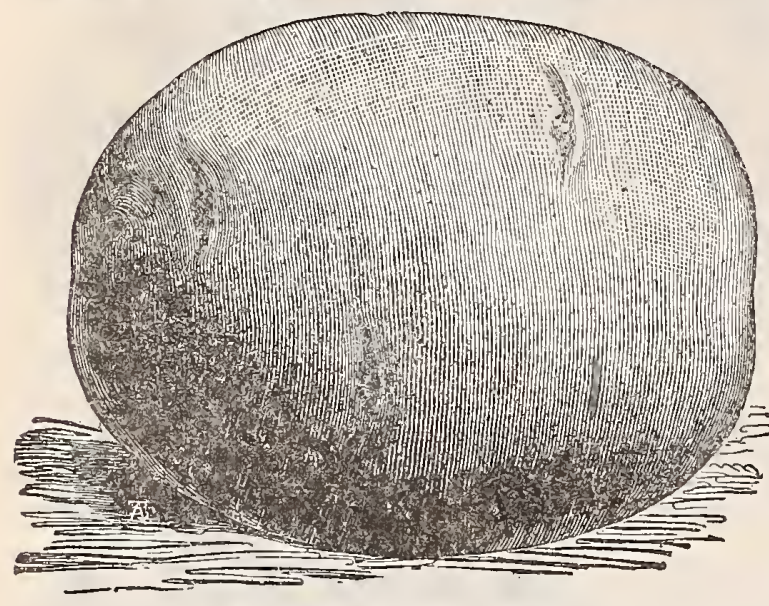

Early Red Triumph Potato.

Early Red Triumph. This variety has taken the lead over all others for earliness and productiveness. It is of handsome shape and appearance, superior in quality, and admirably adapted to our Southern soil and climate. It is at least a week earlier than the Early Rose, and is rapidly becoming one of our most popular sorts. We offer the second crop seed of this celebrated variety, experience having shown them to be far superior to the Northern grown stock in all respects. Pk. 50c, bu. $\$ 1.25$, bbl. $\$ 3.25$.

White Triumph, or Acme. A hybrid of the Red Triumph and Peerless, having the yielding feature of the first named, and all the table qualities of the latter, with size combined. Outside skin white, which makes it a more desirable sort than our Red Triumph. Pk. 50c, bu. $\$ 1.50$, bbl. $\$ 3.50$.

Early Ohio. A magnificent early potato. It is a week earlier than the Early Rose, which it resembles in color, but is a little rounder in shape. It is one of the best early potatoes grown either for market or family garden. Pk. 50c, bu. $\$ 1.25$, bbl. $\$ 3.25$.

Early Rose. We have the pure, genuine Early Rose seed. Pk. 50c, bu. $\$ 1.25$, bbl. $\$ 3.25$.

Henderson's Early Puritan. Extremely early; the tubers are handsome, perfectly white, and its cooking qualities are the very best, being very mild flavored and as dry as a ball of flour. Pk. 50c, bu. $\$ 1.50$, bbl. $\$ 3.50$.

We can also supply the following well known varieties at prices same as Early Rose:
Beauty of Hebron.
N. Y. State Burbank.
Early Peerless.
Rural New Yorker No. 2.

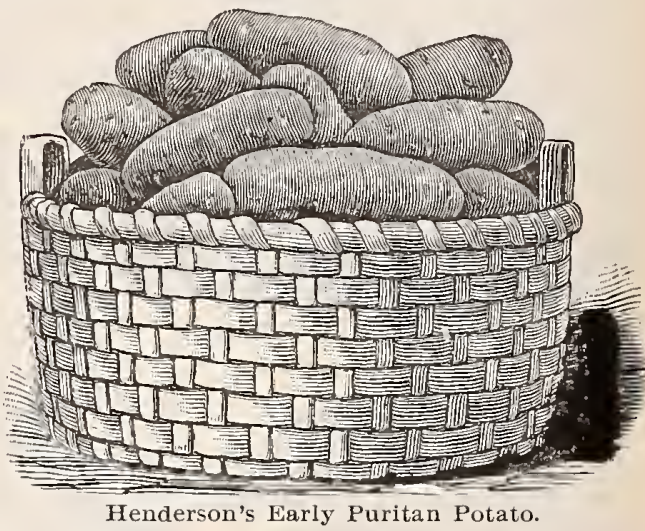

\section{Seed Sweet Potatoes.}

We generally commence shipping seed sweet potatoes about the 15 th of March, as weather before that time is entirely too cold, and potatoes will rot when handled or bedded too early. We take every precaution to see that they are in good condition when they leave here, but will not be responsible for any loss from decay or otherwise after delivery to transportation company.

Bunch Yellow Yam. Each year the popularity of this valuable yam sweet potato increases. Vines do not run-grow erect. Can be cultivated with a plow as easily as corn. The bunch yam is fully six weeks earlier than the old-fashioned yellow yams and will make a larger number of bushels per acre than the old variety. In quality they are sweet and sugary. $\frac{1}{2} \mathrm{pk} .35 \mathrm{c}, \mathrm{pk} .50 \mathrm{c}$, bu. $\$ 1.50$, bbl. of $2 \frac{1}{2}$ bu. $\$ 3.75$.

New Spanish Bunch Yam. See novelties.

Genuine Yellow Yam. Pk. 50c, bu. \$1.25, bbl. $\$ 3.25$.

Southern Queen. Pk. 50c, bu. \$1.25, bbl. $\$ 3.25$.

Early White Strasburg. Pl. 50c, bu. $\$ 1.25$, bbl. $\$ 3.25$.

Red Brazilian. Pk. 75c, bu. \$2, bbl. $\$ 3.75$.

SLIG SHOF-..HAMAOND'S Guaranteed to destroy potato bugs and those on tomato and egg (lants, currant worms, cabbage lice and worms, fleas, beetles and mental trees. Pound box $15 \mathrm{c}$, by mail 30c, 5 lb. package 35c, $10 \mathrm{lb}$. package $60 \mathrm{c}$. 


\section{RADISH.}

All varieties thrive best in light, sandy loam. For early use sow in hot -bed in February, giving plenty of ventilation, or outside in drills as soon as the soil can be gotten in order, covering the seed about half an inch deep. Sow every two weeks from March to September for a succession. They must grow rapidly to be crisp, mild and tender. One ounce for one hundred feet of drill; eight to ten pounds for an acre.

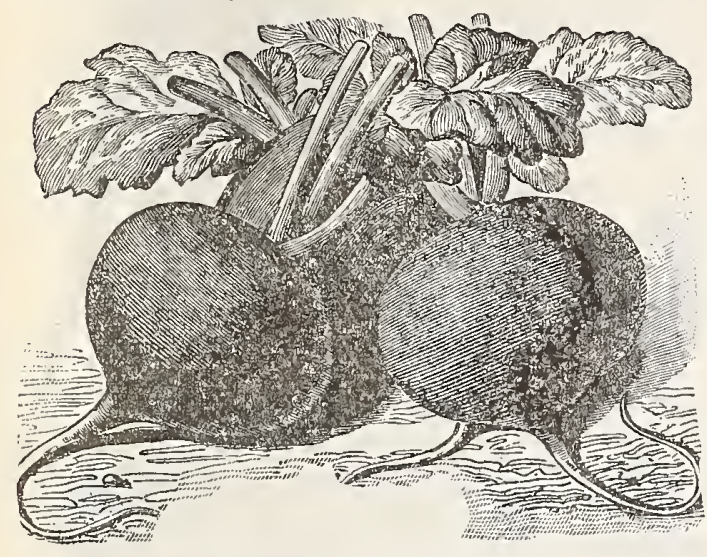

Non Plus Ultra Radish.

Non Plus Ultra. (Deep Scarlet Forcing Turnip.) The earliest forcing radish in cultivation; roots small, round, deep rich scarlet, and crisp, tender, white flesh. Oz. 10c, 2 oz. $15 \mathrm{c}, \frac{1}{4} \mathrm{lb} .25 \mathrm{c}, \mathrm{lb} .85 \mathrm{c}$.

Early Scarlet Turnip, White Tipped. Handsome, bright scarlet, white tipped. Many gardeners make sowings of it every two weeks during summer. Its fine appearance attracts customers; quality always pleases. Ounce $10 \mathrm{c}, 2 \mathrm{oz} .15 \mathrm{c}$, 妾 pound $20 \mathrm{c}$, pound $65 \mathrm{c}$.

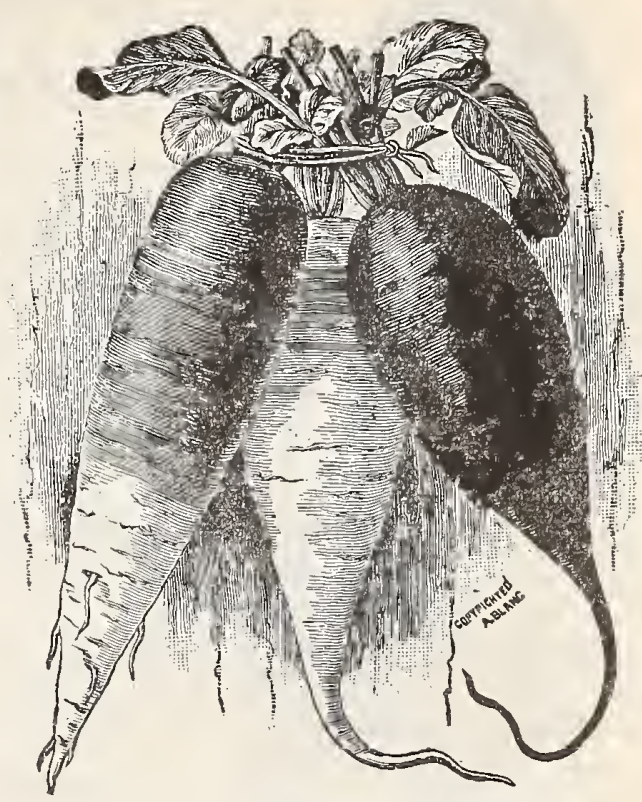

Chartier Strasburg, Half Long Scarlet.

Improved Chartier. One of the most distinct varieties; color scarlet at top, shading to pink at center, and white at tip. It will keep crisp, tender, and retain a mild and pleasant flavor. Oz. 10c, $2 \mathrm{oz}$. $15 \mathrm{c}, \frac{1}{4} \mathrm{lb} .20 \mathrm{c}, 1 \mathrm{~b} .50 \mathrm{c}$.

Long White Vienna (or Lady Finger). Long, white, beautiful shape; skin and flesh pure white and very crisp. Oz. $10 \mathrm{c}, 2$ oz. $15 \mathrm{c}, \frac{1}{2}$ lb. $20 \mathrm{c}, 1 \mathrm{~b} .50 \mathrm{c}$.

Early White Turnip. Pure white, with a small top. Oz. $10 \mathrm{c}, 2 \mathrm{oz} .15 \mathrm{c}, \frac{1}{4} \mathrm{lb} .20 \mathrm{c}, 1 \mathrm{~b} .50 \mathrm{c}$.

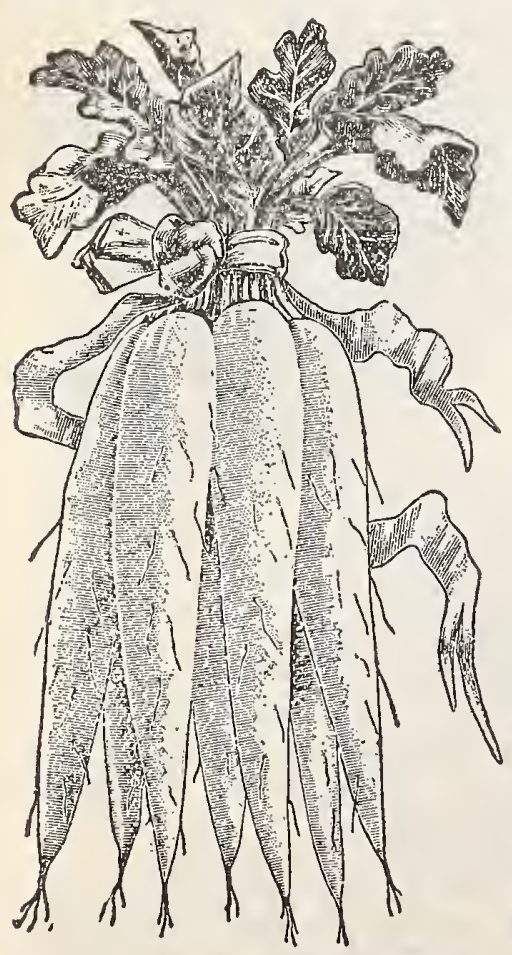

Long White Vienna, or Lady Finger.

New Round Scarlet China. An all-seasons red radish. This new variety of the China radish may be sown at intervals from spring until autumn; it matures in from six to seven weeks, and is much hardier than most other varieties; valuable as a winter radish, as well as for summer. Its handsome round shape, rich scarlet color and pure white flesh commend it to all. Pkt. 5́c, oz. $15 \mathrm{c}, 2 \mathrm{oz} .25 \mathrm{c}, \frac{1}{4} \mathrm{lb} .35 \mathrm{c}, \mathrm{lb} . \$ 1.25$.

Half Long Deep Scarlet. A fine, extra early radish; thin skin and of a bright red color; crisp, solid and white, and has a very handsome form. Ounce $10 \mathrm{c}, 2$ ounce $15 \mathrm{c}$, $\frac{1}{4}$ pound $20 \mathrm{c}$, pound $50 \mathrm{c}$.

Long White Strasburg. A very desirable new summer radish. Oz. $10 \mathrm{c}$, $2 \mathrm{oz} .15 \mathrm{c}, \frac{\pi}{4} \mathrm{lb} .20 \mathrm{c}, \mathrm{lb} .50 \mathrm{c}$.

Early Scarlet Turnip. Very early, in great demand for home use ; small, round, with short top. Ounce $10 \mathrm{c}, 2$ oz. $15 \mathrm{c}, \frac{1}{4} \mathrm{lb} .20 \mathrm{c}, 1 \mathrm{~b} .50 \mathrm{c}$.

Packet 5 cents, three packets 10 cents, any variety.

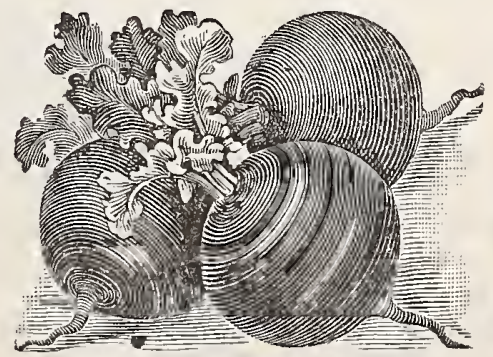

Early Scarlet Turnip Radish.

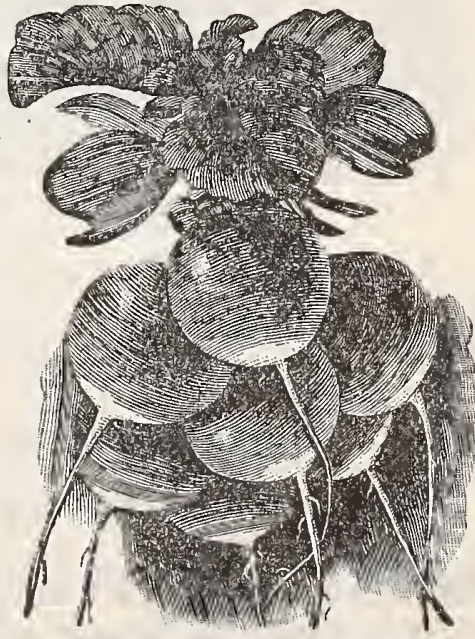

Early Scarlet Turnip, White Tip. 


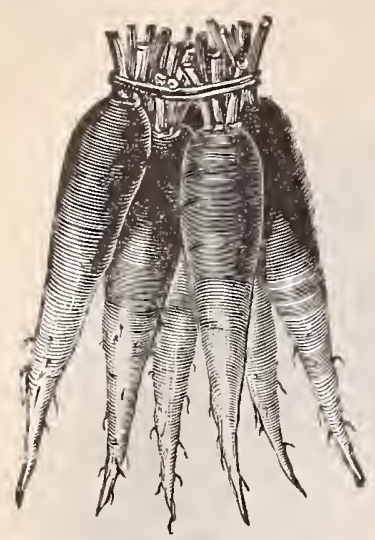

Brightest Long Scarlet.

\section{RADISH-Continued.}

Philadelphia Early White Box. Pure white, brittle and sweet, very early. Ounce $10 \mathrm{c}, 2$ ounce $15 \mathrm{c}$, $\frac{1}{4}$ pound $20 \mathrm{c}$, pound $50 \mathrm{c}$.

Early Long Scarlet. (Short top.) This is the standard sort for gardens and market. Ounce 10c, 2 ounce $15 \mathrm{c}$, \& pound $20 \mathrm{c}$, pound $50 \mathrm{c}$.

Brightest Long Scarlet. (Cardinal White Tipped.) A new sort ; resembles Early Long Scarlet in shape and size; extra early, being fit for use in about twenty-four days after sowing. It is the brightest scarlet we have ever seen in a radish; tips white; a rapid seller. Oz. 10c, 2 oz. 15c, $\frac{1}{4}$ lb. 20c, 1b. 50c.

Golden Globe. Perfect globe shape and golden colored skin; a quick grower, and tender and brittle. Oz. J 0c, 2 oz. $15 \mathrm{c}, \frac{1}{4} \mathrm{lb} .20 \mathrm{c}, 1 \mathrm{~b} .50 \mathrm{c}$.

French Breakfast. Oblong shape, rapid grower, very mild and tender, and beautiful scarlet color tipped with white. Oz. 10c, $2 \mathrm{oz} .15 \mathrm{c}, \frac{1}{4} \mathrm{lb} .20 \mathrm{c}, 1 \mathrm{~b} .50 \mathrm{c}$.

Yellow Summer Turnip Rooted. Very symmetrical and uniform, and nearly round, with grayish white skin covered with a bright yellow russeting, which makes it very attractive. The flesh is compact, white and rather pungent. Ounce 10c, 2 ounce $15 \mathrm{c}$, $\frac{1}{4}$ pound $20 \mathrm{c}$, pound $50 \mathrm{c}$.

Cincinnati Market. A most excellent long radish, of beautiful glossy, brilliant scarlet color. The skin is very thin, and the flesh crisp, brittle and of a delightful pungent quality. It is undoubtedly the finest long red radish for forcing, and will outsell any other on the market. Oz. 10c, 2 oz. $15 \mathrm{c}, \frac{1}{4} \mathrm{lb} .25 \mathrm{c}, 1 \mathrm{~b} .75 \mathrm{c}$.

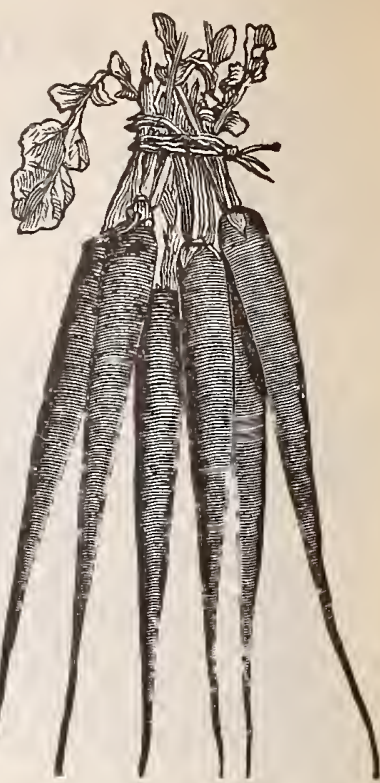

Cineinnati Market.

\section{WINTER VARIETIES.}

Sown in summer and used in the fall, or put away same as turnips. For winter use store in cellar or pits with turnips.

California Mammoth White. A winter variety, growing twelve inches long; white fleshed, firm and of excellent quality. It is the largest radish grown. Oz. $10 \mathrm{c}, 2 \mathrm{oz} .15 \mathrm{c}, \frac{1}{4} \mathrm{lb} .25 \mathrm{c}, 1 \mathrm{~b} .60 \mathrm{c}$.

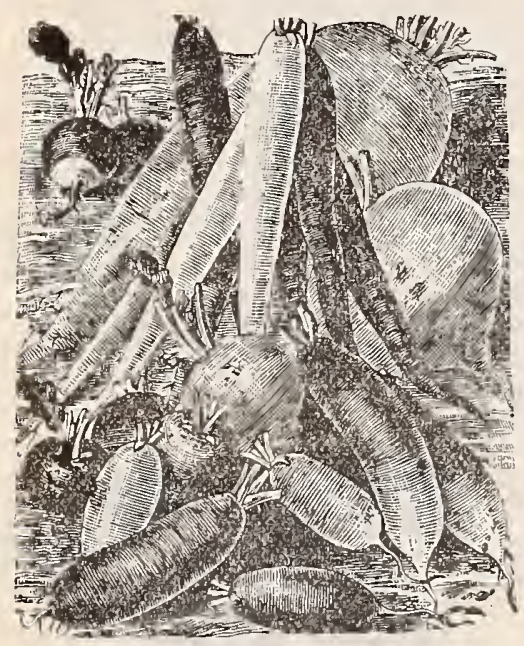

Radish Mixture.

Round Black Spanish. Like the Long Black Spanish, except in shape. Pkt. 5c, oz. 10c, 2 oz. 15c, $\frac{1}{4}$ lb. 20c, 1b. 50c.

Chinese Rose. (Scarlet China.) Bright rose colored winter variety, of excellent quality ; certainly one of the best, and would be more gen-

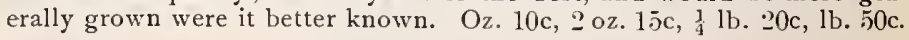

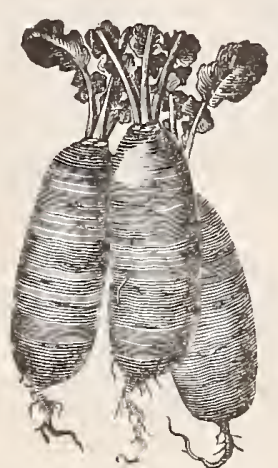

Chinese Rose Winter.

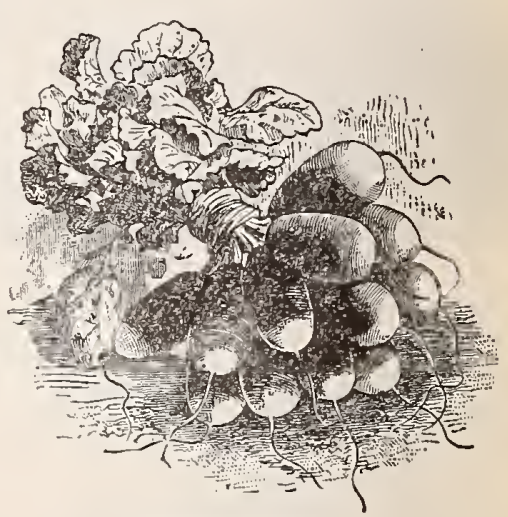

French Breakfast.

RADISH MIXTURE. Our mixture, of about two dozen kinds, contains all shades and shapes-red, white, pink and variegated; round, half long and long -in great variety. One sowing does for the whole season, as they come early, medium and late. You always have some that are right-sweet, juicy, delicious, crisp. You will be surprised and delighted with our popular radish mixture. Large packet $10 \mathrm{c}$, ounce $15 \mathrm{c}$, $\frac{1}{4}$ pound $30 \mathrm{c}$, pound $\$ 1.00$.

\section{USE SCHWILL'S VEGETABLE FERTILIZERS and SEEDS}

And a Good Carden you are Sure to Have.

WAKE A NOTE of the fact that we deliver free to any postofice in the all Vegetable Seeds sold by the packet, ounce, $1 / 4$ ponind, pound, pint or quart. 


\section{Salsify or Oyster Plant.}

One ounce will sow fifty feet of drill; six to eight pounds to an acre. Sow the seed in light, deep soil, early in spring, in drills twelve inches apart and one inch deep, thinning out the young plants to six inches.

Pkt. 5c, 3 pkts. 10c.

Mammoth Sandwich Island. A mammoth good variety, grows uniform and smooth. $\frac{1}{2}$ oz. 10c, oz. 15c, 2 oz. 25c, $\frac{1}{4} \mathrm{lb}, 40 \mathrm{c}, 1 \mathrm{lb} . \$ 1.25$.

Mammoth White. A well known and standard sort. Oz. 10c, $2 \mathrm{oz} .20 \mathrm{c}$, $\frac{1}{4} 1 \mathrm{~b} .35 \mathrm{c}, 1 \mathrm{lb} . \$ 1$.

\section{Spinach.}

One ounce to sixty feet of drill; eight to ten pounds to the acre. For an early summer crop sow early in the spring, in drills, one foot apart, and thin out to two inches in the row. For winter and early spring crop sow either broadcast or in drills about the first of September, or later.

Curled Savoy Leaved. The hardiest of all varieties of spinach ; the leaves are curled and wrinkled like Savoy cabbage. Oz. 5c, 2 oz. 10c, ll $1 \mathrm{~b} .15 \mathrm{c}, 1 \mathrm{lb}$. $35 \mathrm{c}, 5 \mathrm{lbs} . \$ 1.50$, postage paid.

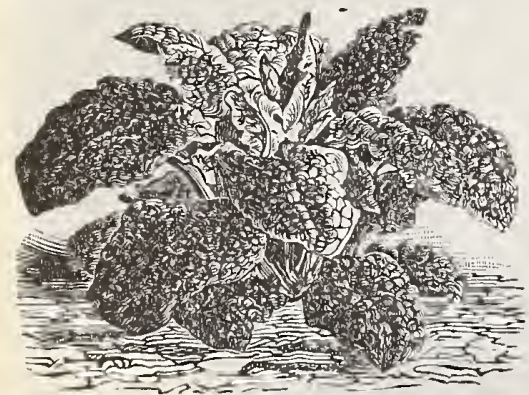

Curled Savoy Leaved Spinach.

New Long Standing. One of the best varieties for spring sowing, as it stands fully two weeks longer than any other sort before running to seed. Oz. 5c, 2 oz. 10c, $\frac{1}{4}$ lb. $15 \mathrm{c}$, $1 \mathrm{lb} .40 \mathrm{c}$.

New Victoria. An excellent new sort, especially desirable on account of its dark green color. Fine for market use. Oz. 5c, 2 oz. 10c, $\frac{1}{4} \mathrm{lb}$. $15 \mathrm{c}, 1 \mathrm{lb} .40 \mathrm{c}$.

Few things are more expensive in the end than buying and planting cheap seed.

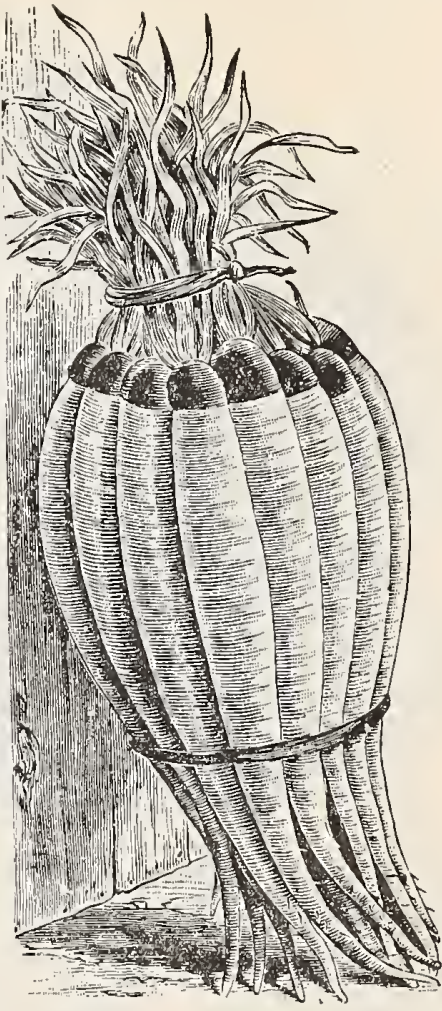

Mammoth Sandwich Island Salsify.

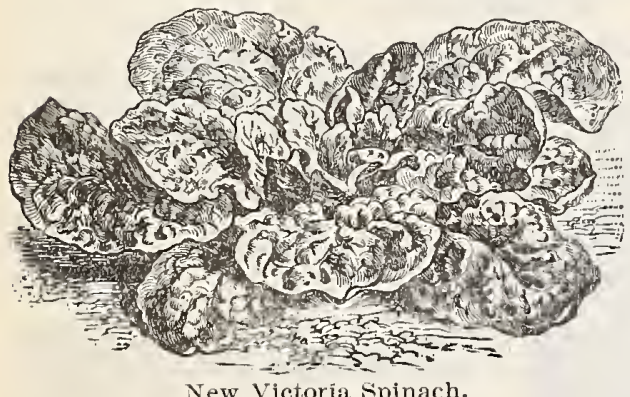

New Victoria Spinach.

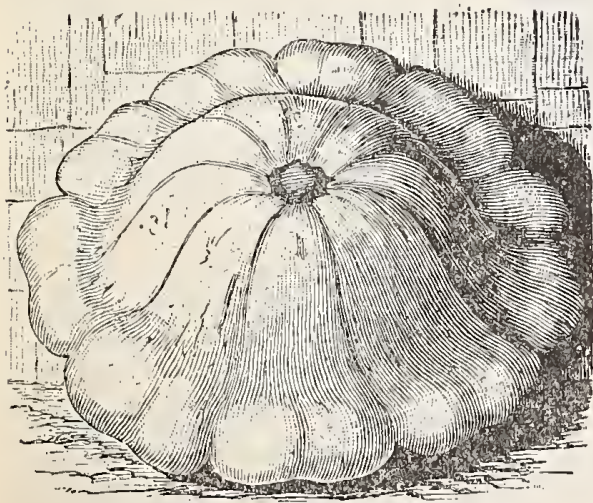

Early White Bush Squash.

\section{Squash.}

One ounce will plant forty to ffity hills; three to four pounds to the acre. Sow about the middle of spring, in hills-the early surt about four feet apart and the late varieties six to eight feet.

Pkt. 5c, 3 pkts. 10c, any variety.

Early White Bush, or Patty Pan. Is earlier than any other variety of bush habit, very productive. $\mathrm{Oz} \cdot 10 \mathrm{c}, 2 \mathrm{oz} .15 \mathrm{c}, \frac{1}{4} 1 \mathrm{~b}$. $25 \mathrm{c}, 1 \mathrm{lb} .75 \mathrm{c}$.

Mammoth White Bush, Scalloped. An improved variety of the well known White Bush, glowing 12 to 15 inches acro:s; a beautiful white color. Oz. $10 \mathrm{c}, 2 \mathrm{oz} .15 \mathrm{c}, \frac{1}{4} \mathrm{lb} .25 \mathrm{c}, 1 \mathrm{lb} .75 \mathrm{c}$.

Yellow Summer Crookneck. One of the best summer varieties. Golden in color. Oz. 10c, $2 \mathrm{oz} .15 \mathrm{c}, \frac{1}{4} \mathrm{lb} .25 \mathrm{c}, 1 \mathrm{lb} .75 \mathrm{c}$.

Giant Summer Crookneck. Grows very much larger than the ordinary Summer Crookneck, and matures earlier. Oz. 10c, 2 oz. $15 \mathrm{c}, \frac{1}{4} \mathrm{lb} .25 \mathrm{c}, 1 \mathrm{lb} .75 \mathrm{c}$.

Yellow Bush. Deep golden yellow, fine quality. always tender, productive. Oz. $10 \mathrm{c}, 2 \mathrm{oz} .15 \mathrm{c}, \frac{1}{4} \mathrm{lb} .25 \mathrm{c}, 1 \mathrm{lb} .75 \mathrm{c}$.

The Hubbard. As a winter squash it cannot be too highly extolled. Oz. 10c, 2 oz. $15 \mathrm{c}, \frac{1}{4} \mathrm{lb} .25 \mathrm{c}, 1 \mathrm{lb} .75 \mathrm{c}$.

Boston Marrow. A good late variety-keeps well. Oz. 10c, 2 oz. $15 \mathrm{c}, \frac{1}{4}$ lb. $25 \mathrm{c}, \mathrm{lb} .75 \mathrm{c}$.

MALONE, Miss., May 12, 190\%.

Dear Sirs :- The Rocky Ford Cantaloupe seed bought of you last year were the finest and best I ever saw. Please send me more seed of the same variety.

W. P. B.irton, M. D.

Russum, Miss., September 20, 1902.

Gentlemen :- Your Early Surprise corn was ready to feed July 10th. Brother farmers, that's the corn you want to reduce your expense bills.
A. M. DALE. 


\section{TOMATO.}

$1 \mathrm{oz}$. to 1500 plants; $1 / 4 \mathrm{lb}$. to transplant one acre.

It thrives best in light, warm soil, not too highly enriched, and depends for highest excellence upon vigorous, unchecked growth in the early stages.

For early crops sow in hotbed, greenhouse, or inside the window or sitting room, where the temperature does not fall below 65 degrees, in February or March; transplanting-to secure stockiness-when three inches high, to pots, cold frames, or other parts of the bed, and about five inches apart. After all danger of frosts is over, transplant finally to open ground, four to six feet apart, according to variety used. Earliness may be promoted by pruning off excessive growth.

Imperial. A splendid new purplish red sort, perfectly smooth, very solid, and has very few seeds. It ripens evenly to the stem, is a strong grower, and is not subject to crack or blight. Although one of the earliest, it continues to bear large fruits till killed by frost. Oz. 30c, $\frac{1}{4}$ lb. $\$ 1,1 \mathrm{~b} . \$ 3.50$.

Early IMichigan. An extra early tomato, valuable for its extreme earliness, coming in ten days to two weeks ahead of any other sort. The fruits are smooth, round-shaped, bright red, nearly uniform in size and shape, prolific yielder. Oz. 25c, ${ }_{4}^{1}$ lb. 75 c, lb. $\$ 2.50$

Matchless. This is undoubtedly one of the best main crop tomatoes in cultivation. The solidity, absence of core, size and color of the fruit, together with its freedom from rot, make this well worthy of the name of "Matchless." Fine both for private and market garden. Oz: 25c, $x \mathrm{lb}$. $75 \mathrm{c}, \mathrm{lb} . \$ 2.50$.

Trucker's Favorite Tomato. A very large purple tomato, very solid and free from cracks or rot. $\mathrm{Oz} .50 \mathrm{c}$, $\frac{1}{4}$ lb. $\$ 1.25, \mathrm{lb} . \$ 4$.
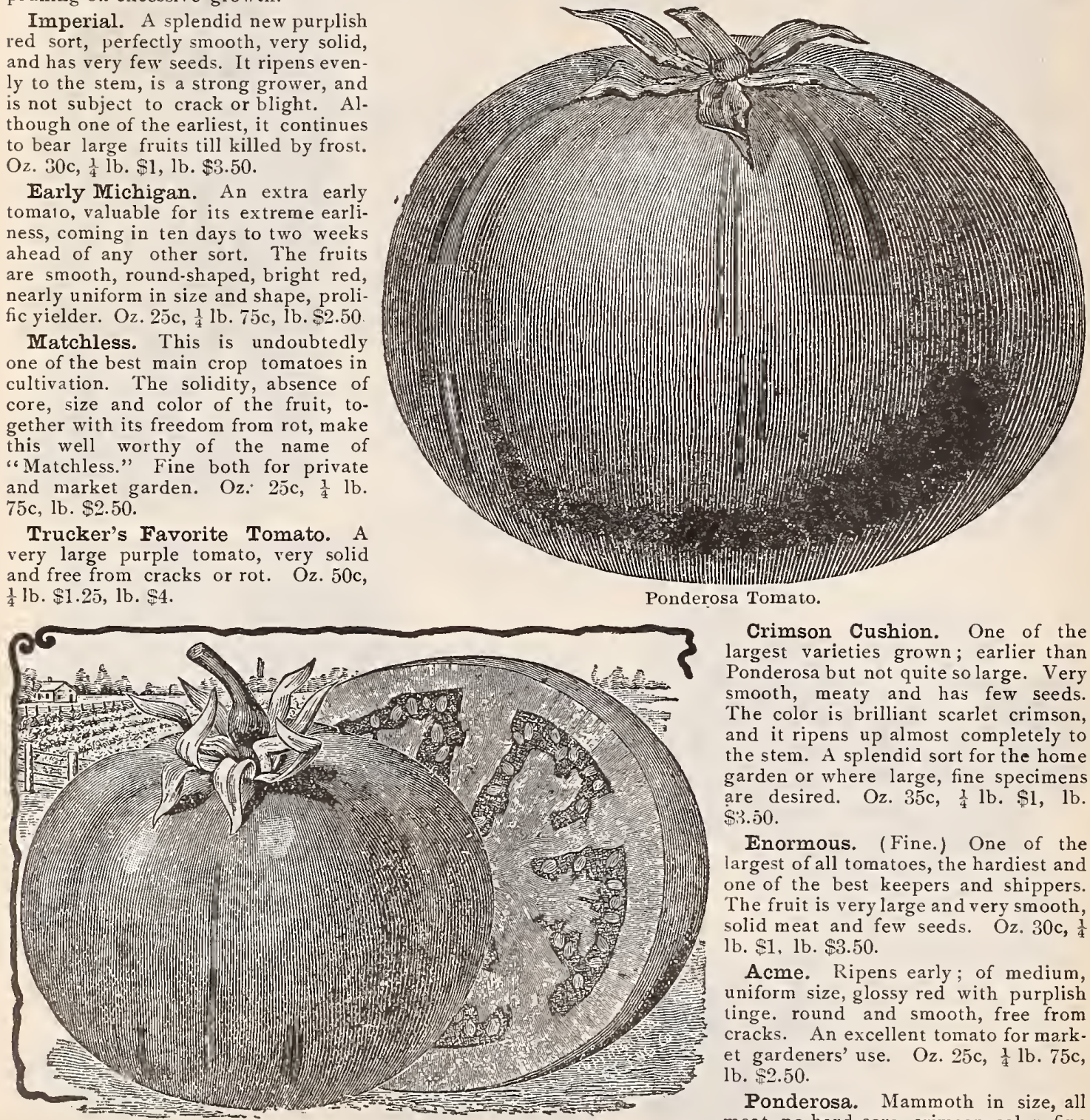

Crimson Cushion. One of the largest varieties grown; earlier than Ponderosa but not quite so large. Very smooth, meaty and has few seeds. The color is brilliant scarlet crimson, and it ripens up almost completely to the stem. A splendid sort for the home garden or where large, fine specimens are desired. Oz. $35 \mathrm{c}, \frac{1}{4} \mathrm{lb} . \$ 1,1 \mathrm{~b}$. \$i.jo.

Enormous. (Fine.) One of the largest of all tomatoes, the hardiest and one of the best keepers and shippers. The fruit is very large and very smooth, solid meat and few seeds. Oz. 30c, $\frac{1}{4}$ lb. $\$ 1,1 b . \$ 3.50$.

Acme. Ripens early; of medium, uniform size, glossy red with purplish tinge. round and smooth, free from cracks. An excellent tomato for market gardeners' use. $\mathrm{Oz} .25 \mathrm{c}, \frac{1}{4} \mathrm{lb} .75 \mathrm{c}$, lb. $\$ 2.50$.

Ponderosa. Mammoth in size, all meat, no hard core, crimson color, fine flavor. Oz. 40c, $\frac{1}{4}$ lb. $\$ 1.25,1 b . \$ 4.50$.

Tobacco Dust Insecticide. One of the cheapest and most effective remedies for lice and worms on cabbage, striped bugs and other insects on melons, cucumbers and squashes. Dust on the young plants when the dew is on. This insecticide is also most effective to dust on seed beds of cabbage, cauliflower, etc., in order to prevent the attacks of the flea, which sucks the life out of the plants just as they are coming up. It is also largely used on melon and cucumber hills, etc., to prevent the attacks of insects while these plants are young. The tobacco dust also acts as a fertilizer and stimulates the growth of plants, and really makes one of the cheapest and best insecticides in use. Every farmer, gardener and trucker should alwayshave a supply of this insecticide on hand, so as to have it available when needed. Price: 1 lb. package $15 \mathrm{c}$, $j$ lb. package $50 \mathrm{c}$; by mail, $1 \mathrm{lb} .25 \mathrm{c}$, postage paid. 


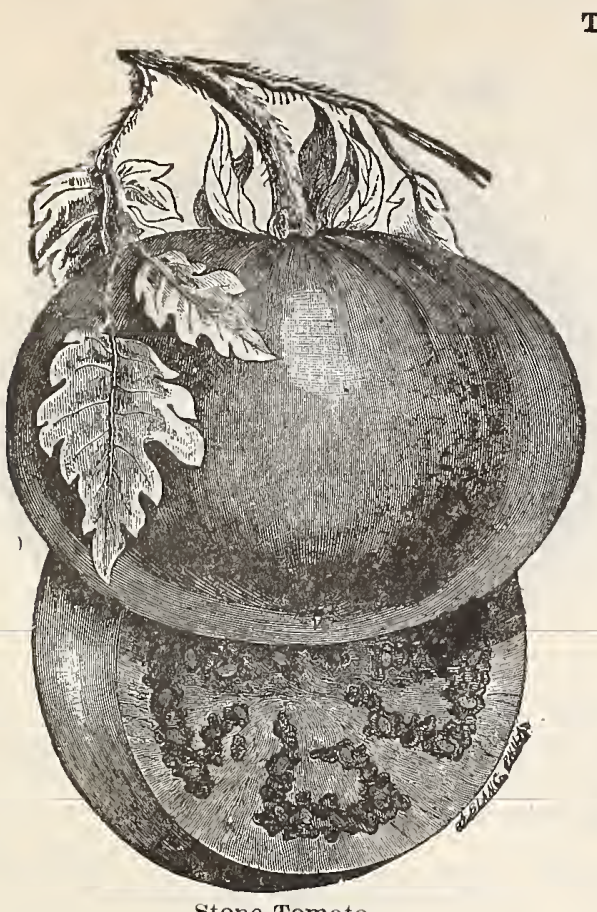

Stone Tomato.

Stone. This variety has obtained great favor with canners, Southern growers, and market gardeners every. where. Its color is a desirable red; in shape, perfectly smooth, and thicker from stem to blossom end than most varieties, making it very handsome and salable. $\mathrm{O} z$. 25 c, $\frac{1}{4} \mathrm{lb} .75 \mathrm{c}, \mathrm{lb} . \$ 2.50$.

Paragon. A large size variety, medium in ripening. Color of skin deep, glossy red; flesh solid, well colored and flavored. Oz. 25c, $\frac{1}{4} \mathrm{Ib} .75 \mathrm{c}, 1 \mathrm{~b}$. $\$ 2.50$.

Early Ruby. "The best tomato I have ever tried," is the opinion of a well known tomato specialist. The vines are vigorous, with small leaf, and when quite young begin bearing fruits which are of fair size, of good shape and dark red color. They ripen evenly, remain solid a long time and never crack. Oz. 30c, $\frac{1}{4}$ Ib. 85 c, lb. $\$ 3$.

Dwarf Champion. Dwarf and compact in growth, the plants grow stiff and upright, with foliage unlike most others. Fruit in form and color like Acme. Recommended for the home garden. Oz. 25c, $\frac{1}{4} \mathrm{Ib} .75 \mathrm{c}, \mathrm{lb} . \$ 2.75$.

Trophy, True. Fruit very large and generally smooth; solid, good flavor and very productive. Choice selected seed, as good as can be grown. Oz. 25c, $\frac{1}{4} \mathrm{Ib} .75 \mathrm{c}, \mathrm{Ib} . \$ 2.25$.

All varieties of Tomatoes on our list are sold at $5 \mathrm{c}$ per pkt., 3 pkts. for $10 \mathrm{c}$, unless noted otherwise.

We also have the following well known and standard varieties. Prices uniform. Oz. 25c, l lb. 75 c, lb. $\$ 2.25$, postpaid.

Mikado or Hybrid,

Livingston Beauty,

Livingston Perfection,

Yellow Pear Shape.

Benton, ArK., May 7, 1902.

Your seeds came quick and prompt. You are the kind to deal with. From now on shall speak a good word for you everywhere I go. Great success to you.

Rev. Jas. M. Cline.

Beavers, Tenn., November 10, 1902.

GeNTLEMEN :-All of the trees bought of you are growing fine. They were smooth and good size, and your packers understand their business. I am done with the tree agent. Your trees are better and cheaper.

M. C. RoBERTS.
Livingston's Magnus. A distinct new variety, larger than either the Acme or Beauty, thicker, heavier nd more solid than either, making it a desirable variety, ripens up evenly, does not crack about the stem, a beau.

. n a tree-like form and bearing large, plump red fruit hat is extremely solid, hard and of excellent quality. kt. $10 \mathrm{c}, \mathrm{oz} .50 \mathrm{c}$.

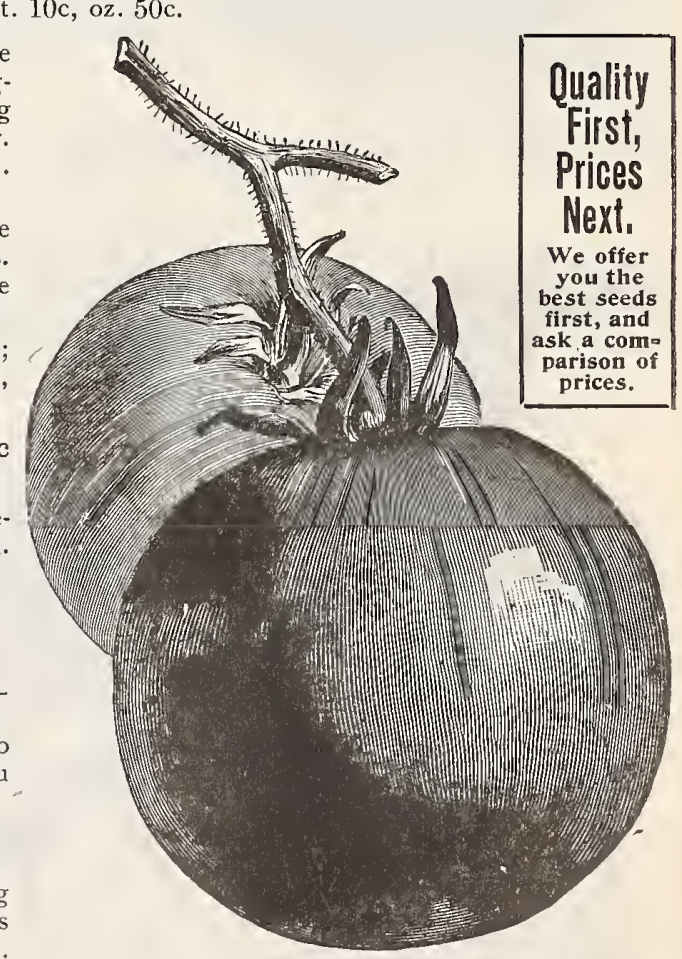

True Trophy Tomato. 


\section{TURNIPS.}

One ounce will sow 100 feet of drill; two pounds per acre, broadcast. Turnips do best in a highly enriched, sandy, gravelly, or light loamy soil. Commence sowing the earliest varieties in February. For a succession, sow at intervals of a fortnight until the last week in May, and from the last of July to the end of September, sowing may be made for the fall and main crops.

White Egg. A quick-growing, egg shaped, perfectly smooth pure white variety with small top and rough leaves. The flesh is very sweet, firm and mild, never having the rank, strong taste of some of the early varieties. Oz. $5 \mathrm{c}$, $\frac{x}{4} \mathrm{lb} .15 \mathrm{c}, 1 \mathrm{lb} .50 \mathrm{c}$.

Cow Horn, or Long White. This variety is pure white, except a little shade of green at the top. It is delicate and weil flavored, and has obtained considerable favor as a market sort for fall and early winter use. Oz. 5c, $\frac{1}{4}$ lb. $15 \mathrm{c}, 1 \mathrm{lb} .50 \mathrm{c}$.

Red or Purple Top, Strap Leaved. This is an early variety and a great favorite for table use; form flat, like a broad disc, and of medium size; color purple or dark red above ground, white below; flesh white, fine grained and tender. Oz. 5c, $\frac{1}{4} 1 \mathrm{~b} .15 \mathrm{c}$, $1 \mathrm{lb} .40 \mathrm{c}$.

Early White Flat Dutch, Strap Leaved. A most excellent early garden variety. Root medium size, flat; color white; very early, sweet and tender. Oz. 5c, $\frac{1}{4} 1 \mathrm{~b} .15 \mathrm{c}, 1 \mathrm{~b} .40 \mathrm{c}$.

Purple Top White Globe. A variety that originated from the Purple Top flat turnip. It is globular and nearly as large as the Pomeranean White Globe and of beautiful appearance. It keeps well and is a fine market sort. Oz. 5c, l l l b. 15c, lb. 40c.

Large White Globe. This is one of the most productive kinds, and in good, rich soil roots will frequently grow to twelve pounds in weight. It is of perfect globe shape, skin white and smooth, leaves large and dark green in color. Oz. 5c, $\frac{1}{4} \mathrm{lb} .15 \mathrm{c}$, $1 \mathrm{lb} .40 \mathrm{c}$.

Ruta-Baga, Improved Purple Top Yellow. Flesh yellow, of solid texture, sweet and well flavored; shape slightly oblong, terminating abruptly; color deep purple above and bright yellow under the ground. $\mathrm{Oz} .5 \mathrm{c}$, $\frac{1}{4}$ lb. $15 \mathrm{c}, 1 \mathrm{lb} .40 \mathrm{c}$.

Extra Early Purple Top Milan, Strap Leaved. No other variety can equal it for spring sowing. It is of medium size and flat shape, with bright purple top, pure white flesh and excellent flavor. Oz. 10c, 2 oz. 15c, $\frac{1}{4}$ lb. $20 \mathrm{c}, 1 \mathrm{lb} .60 \mathrm{c}$.

Sweet German. Grows to a very large size; flesh white, solid, firm texture, sweet and rich, and keeps well. Oz. 10c, $\frac{1}{4}$ lb. 20c, 1 lb. 60c.

Golden Ball, or Orange Jelly. Undoubtedly one of the most delicate and sweetest yellow fleshed turnips yet introduced. Not of large size, but firm, hard and of most excellent flavor. Oz. 5c, $\frac{1}{4}$ lb. 20c, 1 lb 50c.

We can also supply the following well known varieties at uniform price, viz.: oz. $5 \mathrm{c}, \frac{1}{4} 1 \mathrm{~b} .20 \mathrm{c}, \mathrm{lb} .50 \mathrm{c}$, postage paid :

Large White Norfolk. Yellow Aberdeen. Seven Top Winter Greens. Large Amber Globe. Large White Winter. Large Yellow Globe. Frost King. Yellow Stone.

Laing's Imp. Ruta-Baga. Imperial Ruta-Baga.

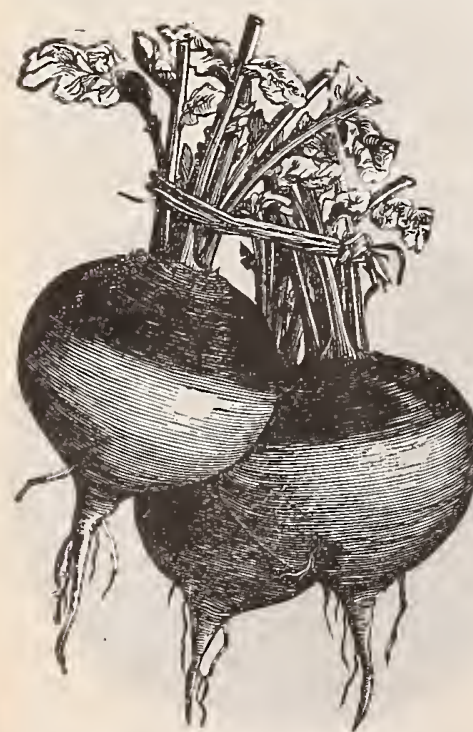

Imp. Purple Top Yellow Ruta-Baga.
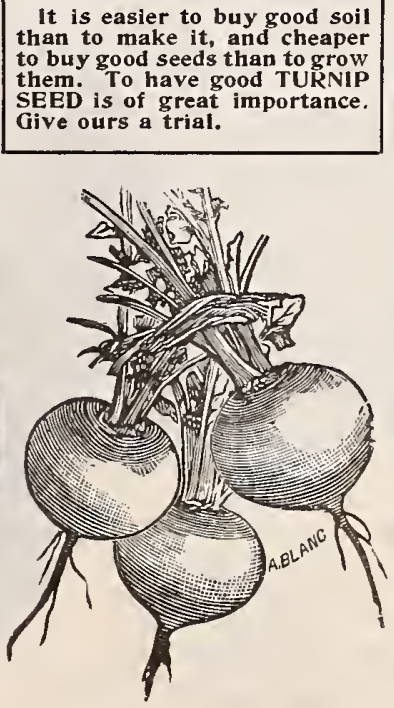

Golden Ball Turnip.

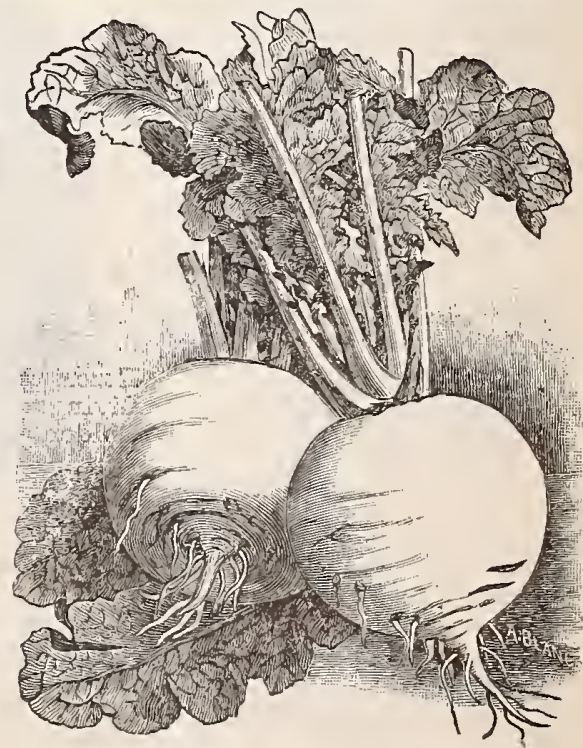

Large White Globe Turnip. 


\section{Herb Seeds.}

Packet 5c, three packets 10c, any variety.

In making up your assortment of seeds for the year, don't neglect to order a few varieties of herbs. They should have a place in every vegetable garden. Sow seeds in shallow drills a foot apart, and when up thin out and transplant to a few inches apart. The chief point is to harvest them properly, which should be done on a dry day, when not quite in full bloom, then dried quickly and packed closely, and entirely excluded from the air. The following are the varieties mostly cultivated:

$\begin{array}{lll}\text { Anise. } & \text { Dandelion. } & \text { Savory Summer. } \\ \text { Borage. } & \text { Dill. } & \text { Savory Winter. } \\ \text { Basil Sweet. } & \text { Marjoram Sweet. } & \text { Sweet Fennel. } \\ \text { Catnip. } & \text { Martynia. } & \text { Sage. } \\ \text { Chicory. } & \text { Lavender. } & \text { Sorrell. } \\ \text { Coriander. } & \text { Rosemary. } & \text { Thyme. }\end{array}$

\section{Rhubarb.}

In March sow in drills in a shady or moist situation. and when a few inches high thin out to twelve inches. The following fall transplant to a deep, well manured soil, four feet apart, and protect with manure or leaves. It may be more quickly grown by setting out the roots, covering the crown every fall with coarse $m$ never allow it to go to seed.

Linnæus. The most desirable variety. Packet $5 \mathrm{c}$, ounce $15 \mathrm{c}$, $\frac{1}{4}$ pound $40 \mathrm{c}$, pound $\$ 1.25$.

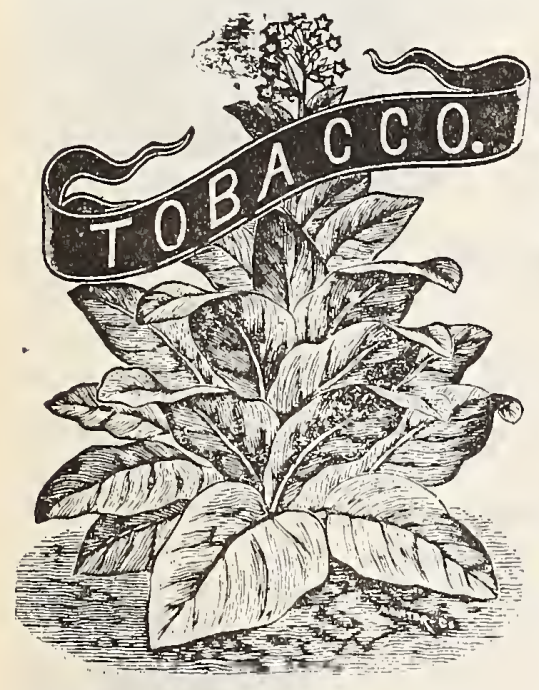

Pkt. 5c, 3 pkts. 10c, any variety.

Balsam Apple. Hercules Club. Balsam Pear. Iuffa Dish Rag. Garden Lemon. Orange Gourd.

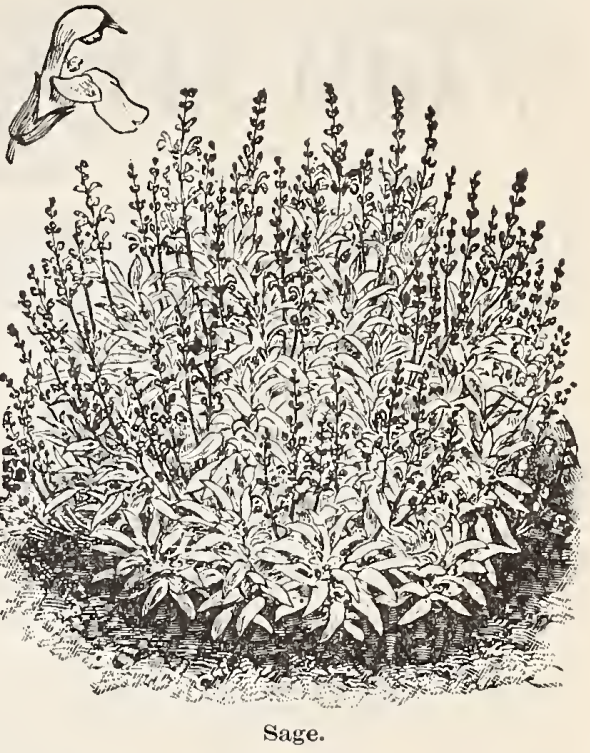

Rhuarb Ro not gat her any the first season, and mailed, add $10 \mathrm{c}$ each for postage.

Large Clumps. Each $25 \mathrm{c}$, doz. $\$ 2$, by express.
Kentucky Burley. A standard, good variety; succeeds where other sorts fail.

\section{Mushroom Spawn.}

Mushrooms may be grown in a warm cellar or shed in winter, or in the open air in summer. Take partially dry, fresh horse manure and lay it in a heap to ferment; turn and mix it well every few days, and when well and equally fermented, which will be in from 10 to 15 days, it may be made into a bed 4 feet wide and about 2 feet deep, mixing it well together and beating or treading it firmly. The spawn may be inserted in pieces about the size of a walnut, about 2 inches deep

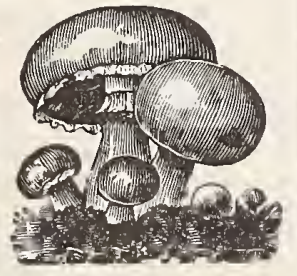
and 6 inches apart, covering with loamy soil.

English. In bricks. Lb. $25 \mathrm{c}$; by mail add $10 \mathrm{c}$ per $\mathrm{lb}$.

\section{Gourds, Etc.} Dipper Gourd. Nest Egg Gourd Ornamental Gourds, mixed. Sugar Trough Gourd.

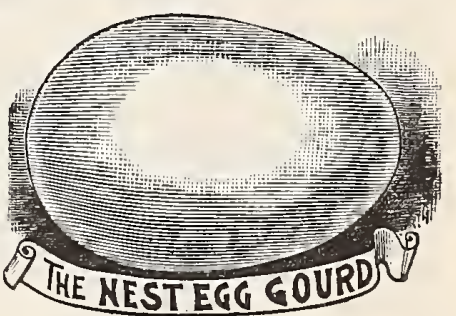

Tobacco.

Packet 5c, three packets for $10 \mathrm{c}$.

One ource will sow about twenty-five square feet and produce plants for one acre. The following varieties have been thoroughly tested in this climate. Early in the spring burn a brush pile on the ground to be used for the seed bed; then thoroughly pulverize the soil, digging and mixing in ashes. Sow seeds very shallow. When plants are six inches high, ransplant into rows four feet apart.

Conqueror. A superb, light yellow variety; vigorous grower, ripens early, and cures to brightest color.

Havana. The genuine; produces the highest quality of tobacco of this type.

Pryor Yellow. Vigorous grower, delightful flavor.

HORSERADISH SETS. Set small end down, so that the top will be two inches below the surface. The soil should be very rich and well cultivated. Doz. $20 \mathrm{c}, \$ 1$ per 100 , $\$ 6$ per 1000 ; by mail, doz. 25 c.

CH I VES, or SCHNITTLAUCH. Used for seasoning and for cottage or smear cheese. Large Clumps, each $25 \mathrm{c}$, by express only.

HUSK OR STRAWBERRY TOMATO. This delicate, husk-enveloped tomato is unequaled for making preserves and pies. Dried in sugar, as raisins or figs, or to use in fruit cake, they are unexcelled. They are handsome in color, and keep until mid-winter or longer. They have a strawberry flavor, and produce fruit in great abundance. Pkt. 5c, oz. $35 \mathrm{c}$. 


\section{FARM SEEDS.}

WE make a specialty of farm seeds and are at all times prepared to furnish the best varieties of Seed Grain, Seed Oats, Seed Corn, Clovers and Grass Seed at such prices that it will not pay anyone to plant poor seed. :: :

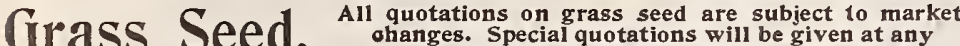 time. State what quantity you wish.}

Bromus Inermis, or Awnless Brome Grass. This has proved to be the best grass of any yet tried. From Winnipeg to the western coast it has stood the rigor of the winter, and yielded from three to four tons of hay per acre. Comes early into growth, thrives well in loose soils, withstands dry weather, grows freely in rich, damp soil, and forms a close sward; produces a heavy aftermath of succulent leafy shoots. Where a permanent lay is desired, Bromus Inermis will fill the bill. Sow twenty-five pounds per acre. Lb. 35 c, postage paid; by freight, lb. 25 c, 10 lbs. $\$ 2,100$ lbs. $\$ 16$.

Orchaid Grass. A standard grass, well known, one of the very best in cultivation. Fourteen pounds to the bushel. Sow one and one-half bushel per acre. Lb. 35c, postage paid; by freight, pk. $75 \mathrm{c}$, bu. $\$ 2.25$.

Timothy. Succeeds well on good soil. Lb. 25 c, postage paid; by freight pk. $75 \mathrm{c}$, bu. $\$ 2.50$.

Perennial Rye Grass. A permanent grass for meadows and pastures, or for mixing with other grasses. Sow twenty pounds per acre. Lb. 30c, postage paid; by freight, $10 \mathrm{lbs} . \$ 1.20,100 \mathrm{lbs} . \$ 8.50$.

Herd Grass, or Red Top. It makes a fine, close turf. Fourteen pounds per bushel; sow two bushels per acre. Lb. 20c, postage paid; by freight, pk. $25 \mathrm{c}$, bu. $75 \mathrm{c}$.

Fancy Re-cleaned Red Top. Extra re-cleaned seed; requires only six pounds per acre. Lb. 35 c, postage paid; by freight, lb. $25 \mathrm{c}, 10 \mathrm{lbs}$. \$2. 100 lbs. $\$ 14$.

Tall Meadow Oat Grass. For either hay or permanent pasture; it does well on any soil, but of special value on clay land; thirty pounds per acre. Lb. 40 c, postage paid; by freight, $10 \mathrm{lbs} . \$ 2.50,100 \mathrm{lbs} . \$ 20$.

Kentucky Blue Grass. The famous pasture grass of Kentucky; for lawns it has no superior; two to 3 bushels of seed per acre; fancy, clean seed. Lb. 3óc, postage paid; by freight, lb. 25 c, 5 lbs. $\$ 1$, bu. $\$ 2.50$.

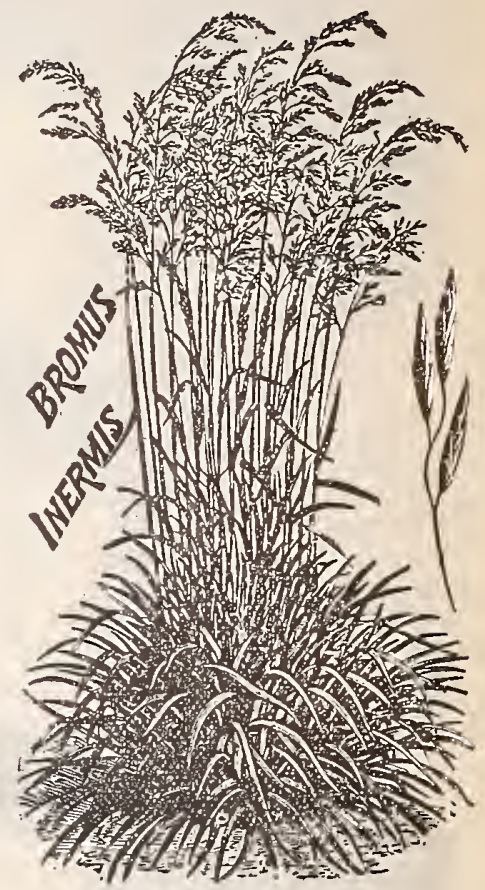

Meadow Fescue, or English Blue Grass. Valuable as pasture grass, being one of the earliest in the spring and the latest in the fall. It also makes excellent hay. Sow thirty pounds per acre. Lb. 30c, postage paid; by freight, $10 \mathrm{lbs}$. $\$ 1.50,100 \mathrm{lbs}$. $\$ 12$.

Sheep's Fescue. Grows naturally on light, sandy, dry soils. Considered quite valuable mixed with other grasses for permanent early spring pasture. Sow fifteen pounds per acre; bushel about twelve pounds. Lb. 45 c, postage paid; by freight, 10 lbs. $\$ 2.50,100$ lbs. $\$ 20$.

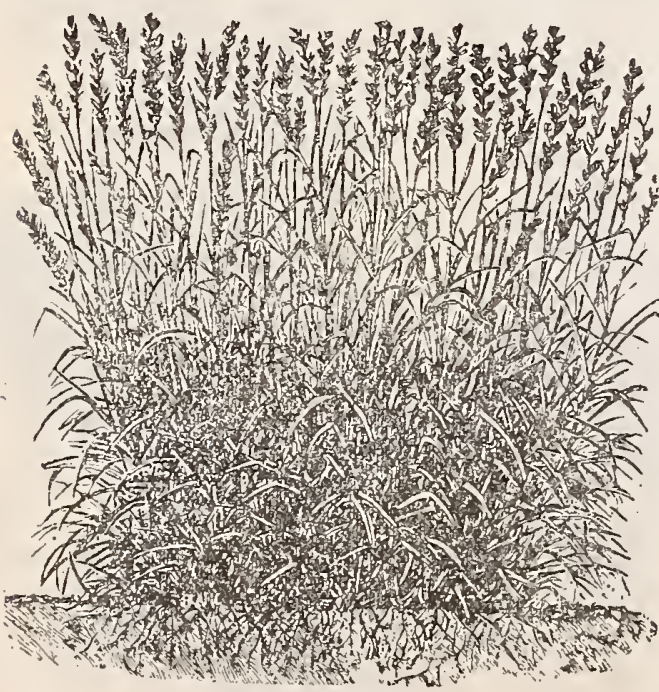

Perennial Rye Grass.
Italian Rye Grass. For low, rich soil ; makes nutritious hay; yields two cuttings a season; being an annual it must be sown yearly; sow twenty pounds to the acre. Lb. 30c, postpaid; by freight, 10 lbs. $\$ 1.50,100$ lbs. $\$ 10$.

Emerald Lawn Grass. Will produce a permanent, heavy, carpet-like lawn. Best re-cleaned seed, equal to any variety. Fourteen pounds to a bushel. For new lawns use three to four bushels; renewing old lawns sow one to two bushels. One pound will plant $20 \times 30$ feet. Lb. 40 c, postpaid; by freight, lb. 30c, 4 lbs. $\$ 1$, bu. $\$ 3$.

Rough S Stalked M eadow Grass. An excellent grass for meadows and stiff, heavy clays. It gives a constant supply of highly nutritive herbage, for which horses, sheep and cattle show a marked partiality. Height two to three feet. Lb. $60 \mathrm{c}$, postage paid; by freight, 10 lbs. $\$ 4.50$. 100 lbs, $\$ 40$.

Bermuda Grass. This is a valuable grazing grass, also fine for lawns. For railroad embankments, mill dams, etc., it is firstclass, as its long creeping roots soon form a compact mass, holding the soil together and preventing it from washing or gullying. Sow in March or April at the rate of from three to five pounds per acre. Prepare the ground well and cover very lightly. Lb. $\$ 1$, postage paid; by freight or express, 1 lb. $90 \mathrm{c}, 10$ lbs. $\$ 8$.

Headquarters for Poultry Supplies.

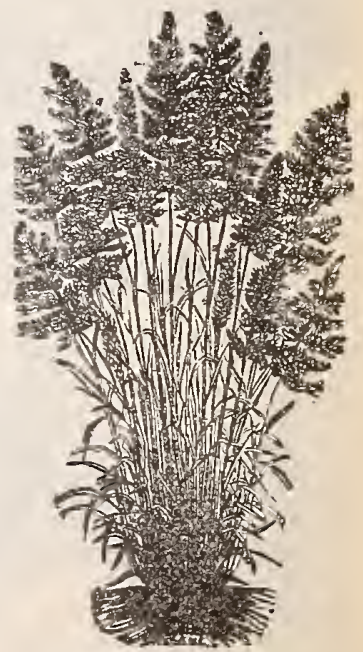

Meadow Fescue, or English Blue Grass. 
GRASS SEED-Continued.

Our Special Pasture Grass Mixture. To obtain the best results for pasture, we advise sowing the different varieties mixed, which yields grazing for both summer and winter. Our mixture consists of Orchard and Herds Grass, Meadow Fescue, English Rye Grass, Creeping Bent Grass, Tall Meadow Oat Grass, and Timothy. In addition to these, which should be sown separately, can be added about five pounds of Red Clover, which is worth 20 cents per pound. Sow one and one-half bushels of our mixed grass to the acre. Weight fourteen pounds to the bushel. Lb. 20 c, pk. 50 c, bu. $\$ 1.75,3$ bu. $\$ 1.50,5$ bu. $\$ 7$; by mail, lb. 30 c.

\section{GRASS SEED MIXTURES.}

It is a well ascertained fact that a thicker and more prolonged growth is produced by a mixture of many sorts of grasses than by only one or two. For every different kind and condition of soil there are grasses that are especially suitable. Some sorts do best on high ground and in dry weather; others prefer plenty of moisture. Some mature so early, and others so late, that from the beginning of spring until winter sets in, there is no time when one species or another is not at its best. Grass seeds may be sown either early in spring or in fall from first of September to the middle of October in this latitude. Quantities given are the minimum, and may often be increased to advantage.

$25 \mathrm{lbs}$. and over at the $100 \mathrm{lb}$. rate.

Mixture No. 1, for Light Sandy or Loamy Soils. Creeping Bent Grass, Orchard Grass, Fancy Red Top, White Clover, Tall Oat Grass, Hungarian Brome, SheepFescue, Red Clover. Sow 20 lbs. per acre. Lb. 25 c, 100 lbs. $\$ 15$.

Mixture No. 2, for Limestone, Stiff or Loamy Upland Soil. Orchard Grass, Ky. Blue Grass, Perennial Rye, Tall Oat Grass, Fancy Red Top, Red Clover. Sow twenty-five pounds per acre. Lb. $25 \mathrm{c}, 100$ lbs. $\$ 14.50$.

Mixture No. 3, for Heavy Loam or Clay or Bottom Lands. Timothy, Rough Stalked Meadow, Fancy Red Top, Alsike Clover, Red Clover. Sow eighteen pounds per acre. Lb. 30c, 100 Ibs. $\$ 18$.

Mixture No. 4, for Wet Bottom Land Subject to Overflow. English Blue, Red Top, Red Clover, Italian Rye, Rough Stalked Meadow. Sow twenty-five pounds per acre. Lb. 30c, 100 lbs. $\$ 20$.

Mixture No. 5, especially for the South, on any good soil withstanding hot, dry weather. Bermuda Grass, Fancy Red Top, Perennial Rye, Tall Oat Grass. Sow fifteen pounds per acre. Lb. $40 \mathrm{c}, 100 \mathrm{lbs}$. $\$ 28$.

\section{CLOVER SEED.}

Alfalfa, or Lucerne. (Medicago sativa.) The most wonderful forage plant of the world. Gives three to five crops of hay a year, and on rich land containing lime will give more than five cuttings. When fully established it yields as much as eight to twelve, and sometimes sixteen tons of cured hay per acre. It is a perennial and irrigated fields forty years old are known to still be furnishing immense crops. In Louisiana it has been known to produce green food every day in the year, and there is scarcely a state in the Union in which itcan not be successfully grown. Its great ability to stand heat and drouth is due to the long tap root which extends from five to ten feet in the ground. Loose, sandy loam soils, rich, particularly in lime, phosphoric acid and potash, are most suitable for alfalfa, but it will grow anywhere if it has good drainage. After the first year it is used for pasturage under certain conditions, particularly for hogs. Its chief value is for hay and for feeding green. It is also valuable as a soil enricher, as it furnishes nitrogen. From an analysis of the hay it proves to be richer than red clover. If the hay is cut before the plant blooms, it will be more nutritious, though smaller in quantity, than if cut later. In sowing alfalfa the land should be free of weeds, as a better stand results. Use fifteen to twenty pounds of seed per acre. Lb. $35 \mathrm{c}$, postage paid; by freight, lb. $25 \mathrm{c}, 10 \mathrm{lbs} . \$ 2,100 \mathrm{lbs}$. $\$ 14$, bu. $\$ 8.50$.

Red Clover. This variety of clover is more cultivated for hay, pasture and as an enricher of soil than any other. It is frequently used in combination with orchard grass or red top, as they flower and are ready to cut about the same time. Weight sixty pounds to the bushel. Ten pounds will seed an acre. Ey mail, lb. 30c; by freight, lb. 20 c, 10 lbs. $\$ 1.50$, pk. $\$ 2.25$, bu. $\$ 8.50$.

Scarlet, Crimson or German Clover. Does well sown in the spring or fall. It makes a splendid pasture all during the winter. Sow fifteen pounds to the acre. By mail, lb. $25 \mathrm{c}$; by freight, lb. $15 \mathrm{c}, \mathrm{pk} . \$ 1.50$, bu. of sixty lbs. $\$ 4.50$.

Mammoth or Peavine Clover. Difterent from the common red, being a more vigorous grower; will do well on poor, thin soil. Sow ten pounds per acre. By mail, lb. 30c; by freight, lb. $20 \mathrm{c}$, 10 lbs. $\$ 1.80$, pk. $\$ 2.50$, bu. $\$ 9$.

Alsike or Swedish. Hardest of all clovers, and on rich, moist soil yields an enormous quantity of hay or pasturage. Sow six pounds per acre. By mail, lb. 30c; by freight, lb. 20c, pk. $\$ 2.50$, bu. $\$ 9.50$.

Melilotus or White Bokhara. Largely used in the Southern states both for hay and as an improver. It grows larger than alfalfa, and is especially adapted for use on lime lands or calcar. eous soils. Sow twelve pounds to the acre. By mail, lb. $35 \mathrm{c}$; by freight, Ib. $25 \mathrm{c}, \mathrm{bu}$. $\$ 4$.

Japan Clover. (Lespedeza Striata.) Thrives on red clay hills where red clover will fail. Weighs twenty pounds to bushel. Sow in fall or spring one bushel to acre. By mail, lb. $40 \mathrm{c}$; by freight, lb. $30 \mathrm{c}, 4$ lbs. $\$ 1$, bu. $\$ 4.50$.

White Clover. Good for permanent pastures and alawns; sixty pounds to the bushel. Sow six pounds to the acre. By mail, lb. $50 \mathrm{c}$; by freight, lb. $40 \mathrm{c}, 100$ lbs. $\$ 25$.

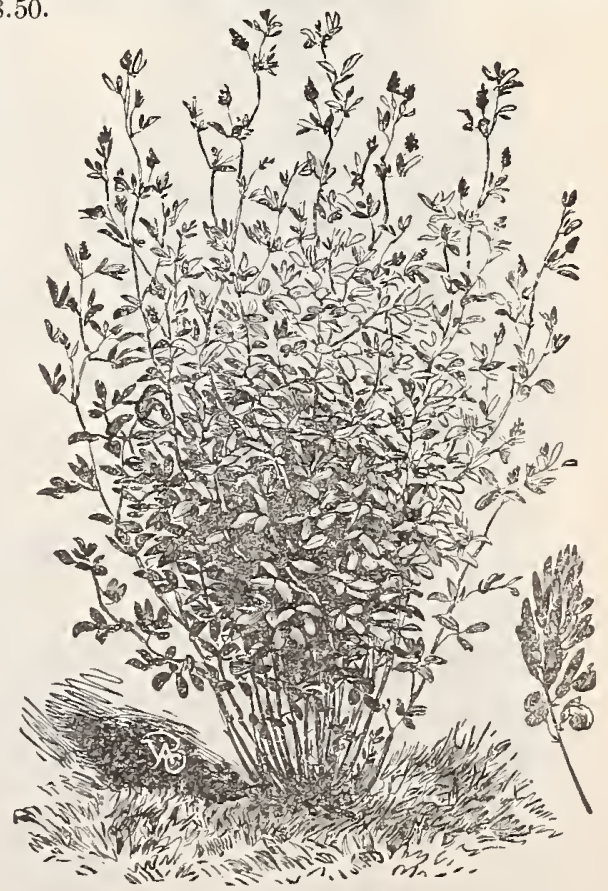

Alfalfa or Lucerne Clover. 


\section{Miscellaneous Forage Plants.}

Dwarf Essex Rape. A very quick growing variety of rape, which makes excellent grazing for sheep, likewise the leaves make very good salad cooked for the table. It can be sown at any season of the year, but is not quite so satis. factory to use in mid-summer as the cooler months of the year. It can be sown broadcast at the rate of eight pounds per acre and raked in, or in drills fifteen inches apart, when four or five pounds will be sufficient. It will be ready to use eight weeks from sowing if the weather is suitable. It is hardy, and will stand any amount of cold. After it has been grazed it will soon be ready again if the sheep are not kept on it too long so as to eat the buds off the stalks. This will be found a cheap, effective food. Lb. 30c, postage paid; by freight, lb. 20c, $10 \mathrm{lbs} . \$ 1,100 \mathrm{lbs} . \$ 8.50$.

Velvet Bean. The velvet bean, or more properly, " pea," is a vining or climbing nitrogenous plant, growing forty or fifty feet high, and greatly enriching the ground. Plant two or three beans in a place in rows four feet apart and one foot apart in the row. They grow very rapidly. In two months the under leaves begin to drop, and by fall the mulch of leaves is often six to eight inches deep, the vines and leaves standing four feet deep. The grow th is so dense that it kills out cocoa or nut grass, Johnson grass or

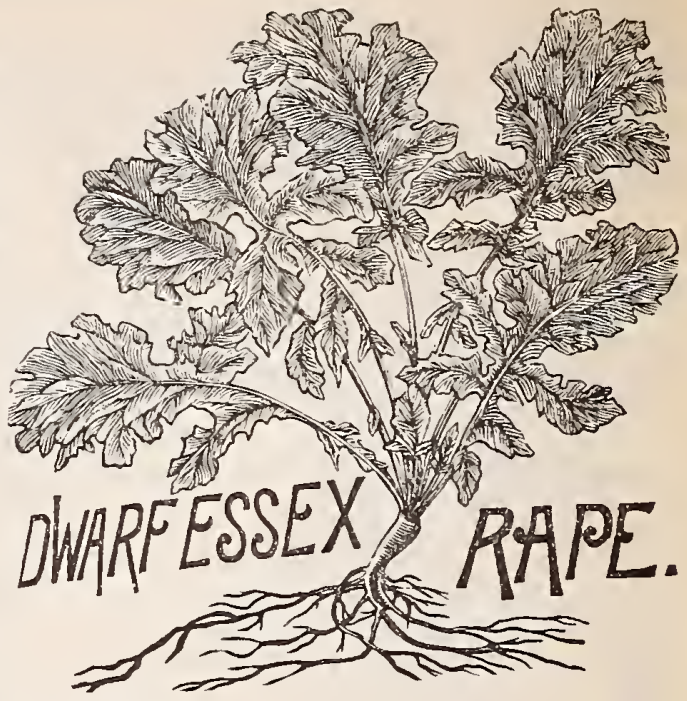
Bermuda. Pkt. 10c, pt. 25c, qt. 45c, postage paid; by freight, pk. \$1, bu. $\$ 3$.

Soja or Soy Bean. This valuable forage plant yearly attracts more attention. It is one of the most nutritious of all vegetable products. For pasturing or feeding as green fodder it is very valuable, and nearly equal to clover for fertilizing. Sow half a bushel per acre broadcast, or a gallon per acre in drills. Large pkt. 10c, lb. $25 \mathrm{c}$, postage

Teosinite (Reana luxurians). A giganti

roader. It is excellent for stock-feeding, either fodder plant, resembling Indian corn, except that the leaves are in drills about four feet a part, using four pounds oreen during summer or dry during winter Sow in May or June,

Winter, Hairy or Sand Vetch. An extremely weather of late fall or early spring months, remainiurdy pea.like plant, which grows strongly during the cool, moist a cover crop it will prevent he land frowing whenever the ground thaws. As a cover crop it will prevent the land from washing during winterstorms and at the same time enrich the soil by storing nitrogen from the air. It succeeds well on light, sandy soils or thin, poor hillsides, where it would be difficult to secure a stand of clover, and the great advantage of having such land covered during the winter with a dense carpet of runing green vines will readily be seen by all farmers, aside from its value as forage. Seed should be sown broadcast or drilled in at the rate of one bushe! per acre. If a half bushel of rye is sown or drilled with the vetch the

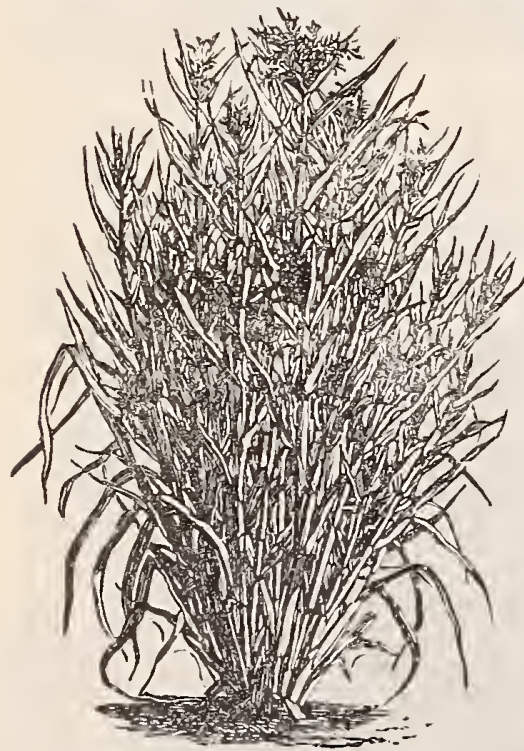
straw will furnish a support for the vines to run on, making them easier to mow for feed or to turn under with the plow. Lb. 35c, postage paid; by express or freight, lb. $25 \mathrm{c}$, pk. $\$ 2$, bu. of $50 \mathrm{lbs} . \$ 6.50$.

Speltz. Speltz is neither wheat, oats, rye or barley, but sort of a combination of all tour. This grain comes from Russia and is a most remarkable cereal. It has been pretty thoroughly tried throughout the northwest and not found wanting for feeding purposes. It is a wonderful "stooler" and robust grower, frequently yielding sixty to seventy-five bushels per acre. While the grain is valuable for milling purposes, its greatest value is for feeding, for which purpose it is superior to either oats or barley. Sow one and one-half bushels per acre. Lb. $25 \mathrm{c}$, postpaid ; by express or freight, lb. $15 \mathrm{c}$, pk. $50 \mathrm{c}$, bu. $\$ 1.50$.

Canada Field Peas. Canada field peas are entirely different from the cow pea, requiring to be sown during the winter and early spring, and making their crop ready for cutting in May or June. They are in. creasing in popularity, usually making a most satisfactory and large yielding early forage crop. They can be sown in open weather during December, January, February or March, at the rate of one and one-half bush. els per acre by themselves, or, sown with oats, one bushel of the peas, and three-quarters of a bushel of winter or rust proof oats per acre. Sowing with oats is of a decided advantage, as the oats help to hold up the peas off the ground, enabling them to make better growth, and as they both mature together, they make splendid food, which cures admirably as hay or dried forage, which is greatly relished and is most nutritious for all farm animals. This crop also makes a good soil improver when turned under like cow peas or crimson clover. Qt. $30 \mathrm{c}$, postage paid; by
freight, pk. $50 \mathrm{c}, \mathrm{bu} . \$ 1.75$.

Teosinite (Reana Luxurians).

GINSENG, its Cultivation, Harvesting and Marketing-by Maurice G. Kains. How to begin with either seed or roots, soil, climate and location, preparation, planting and maintenance of the beds, artificial propagation, manures, enemies, selection for market and for improvement, preparation for sale, profits, etc. Illustrated, $5 x 7$ inches, 54 pages, flexible cloth. Price 50 cents.
JERUSALEM ARTICHOKES. There is no root crop which has grown more rapidly in favor than this one. Hogs fed on them never have the cholera. Plant during eariy spring, in rows four feet apart, two feet in row. Cut same as potatoes leaving one eye. Three bushels will plant an acre. By mail, qt. $25 \mathrm{c}$; by freight, qt. $10 \mathrm{c}, \frac{1}{2}$ pk. $30 \mathrm{c}$, pk. $50 \mathrm{c}$, bu. $\$ 1.25$. 


\section{Seed 0ats, Sorghum and Millet.}

\section{OATS.}

Black Hussar Oat. A heavy black spring oat of extra fine quality, which has given most excellent results throughout this section. Has a stiff straw, stands up well, early to mature, and a most satisfactory variety. Pk. $40 \mathrm{c}, \mathrm{bu} . \$ 1,10 \mathrm{bu} . \$ 8.50$.

Early Burt, or Ninety Day Oats. Always a sure cropper, the earliest and a most prolific variety, especially adapted to light soil. Pk. 3อ̃c, bu. $\$ 1,10$ bu. $\$ 8.50$.

Genuine Texas Red Rust Proof Oats. A heavy yielder and entirely rust proof. Pk. $25 \mathrm{c}$, bu. $80 \mathrm{c}, 10$ bu. $\$ 6.50$.

Winter Turf Oats. For fall sowing. Their deep rooting and stooling properties enable them to afford more fall and winter grazing than any known plant. Sow one and one-half bushels per acre. Can also be sown in the spring and they will make a fine oat for seed, as the spring planting never shows any cheat. Pk. $35 \mathrm{c}$, bu. $90 \mathrm{c}, 10 \mathrm{bu}$. $\$ 8$.

Seed Rye, Seed Barley, Seed Wheat, Etc. We have all varieties for fall planting. Prices on application.

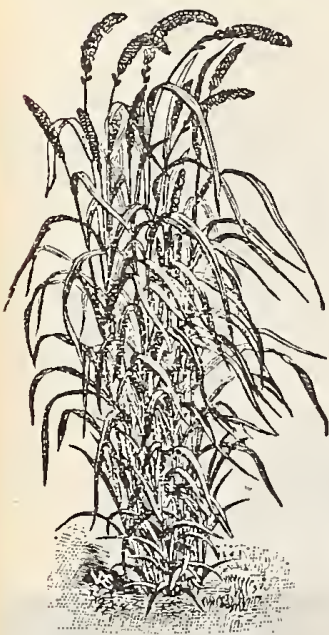

Pearl, or Cat Tail Millet.

\section{MILLET.}

Genuine Golden German Millet. (Tennessee grown.) Decidedly the best variety to grow, producing large crops, seed weigh fifty pounds to the bushel. Requires one bushel to sow an acre. Lb. $25 \mathrm{c}$, postage paid; pk. 50c. bu. $\$ 1.50$.

Pearl, or Cat-Tail Millet. No other plant makes so much forage as this. Seven cuttings can be had from one planting in one season in the Soutb. Stools at ground, has thick foliage. I,b. $35 \mathrm{c}$, postpaid; by freight, 5 lbs. $\$ 1,100$ lbs. $\$ 12$.

Hungarian Grass Millet. Suitable for rich bottom land, where the German millet grows too coarse. Lb. $25 \mathrm{c}$ postage paid; by freight, pk. $50 \mathrm{c}$, bu. $\$ 1.25$.

We want you to get started with uts. Send us an order if only a small one. $\because \therefore \therefore \therefore$

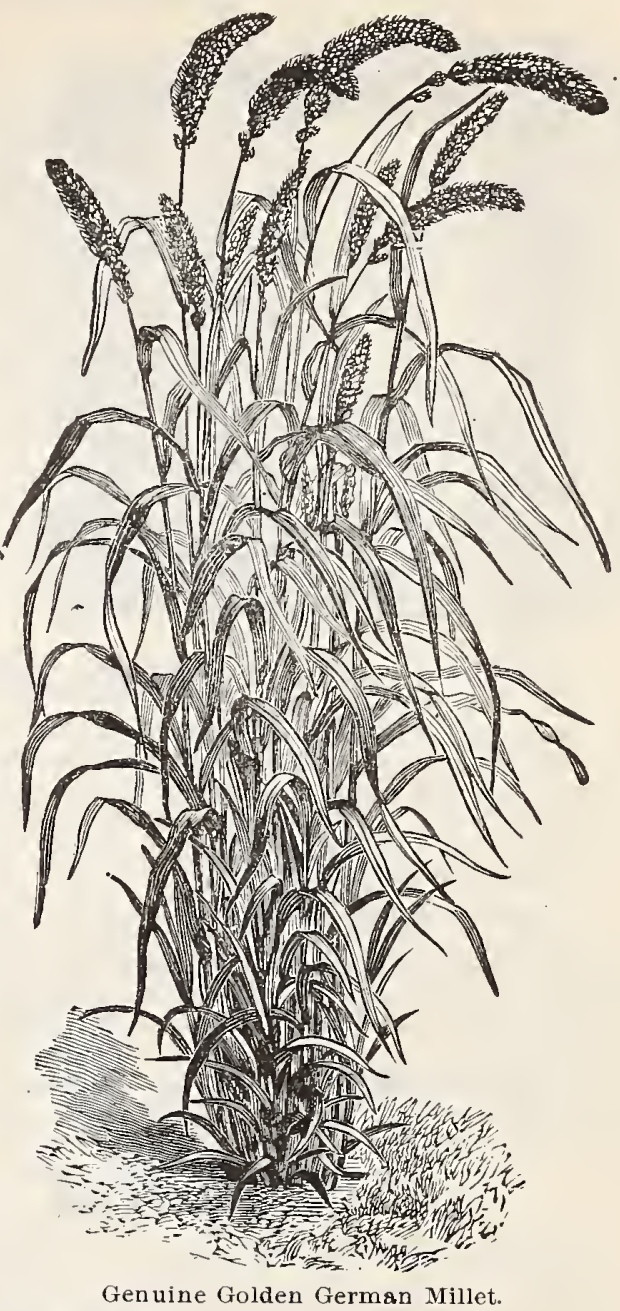

Genuine Golden German Millet.

\section{SORGHUM, OR SUGAR CANE, ETC.}

Early Amber Sorghum. The earliest, makes the finest quality of both sugar and syrup. Lb.20c, postage paid; by freight, pk. $50 \mathrm{c}$, bu. $\$ 1.25$.

Red Kaffir Corn. This grows taller than the white, the stocks are slenderer, more juicy and very leafy. Lb. $25 \mathrm{c}$, postage paid; by freight, pk. $50 \mathrm{c}$, bu. $\$ 1.50$.

Jerusalem Corn. The best and surest grain crop for dry countries and seasons. It grows about three feet high, makes one large bead on the main stalk, and several smaller ones on side-shoots. Eight heads sometimes grow on one stalk. Three pounds will plant an acre. Lb. 25 c. postpaid; by freight, 10 lbs. $\$ 1$, bu. $\$ 2.50$.

Yellow Milo Maize. The growth is tall, nine to twelve feet, stooling from the ground like the Kaffir corn. Lb. $2 \overline{\mathrm{c}} \mathrm{c}$, postage paid; by freight, $10 \mathrm{lbs}$. 50c, bu. ( 50 lbs.) $\$ 2$.

Early Orange Sorghum. Strong growing, much more juicy than any other variety. The stalk is heavier and a little later than the amber. Lb. 20c, postpaid; by freight, pk. $50 \mathrm{c}$, bu. $\$ 1.25$.

Red Top Sorghum. A desirable variety, makes a large quantity of excellent fodder, heads large and heavy. Lb. $25 \mathrm{c}$, postage paid; by freigbt, pk. $60 \mathrm{c}$, bu. $\$ 1.50$.

\section{The COLUMBIA Broadcast Seed Sower.}

We are pleased to call your attention to our Columbia Broadcast Seed Sower for the distribution and sowing of all varieties of farm seeds, and claim for it tbe following points of excellence and superiority over all other makes: perfect in distribution, mechanically constructed, neatest and most simple, has automatic cutoff and regulator. The lightest running of all seed sowers. Strongest in construction. The lowest priced standard machine manufactured.
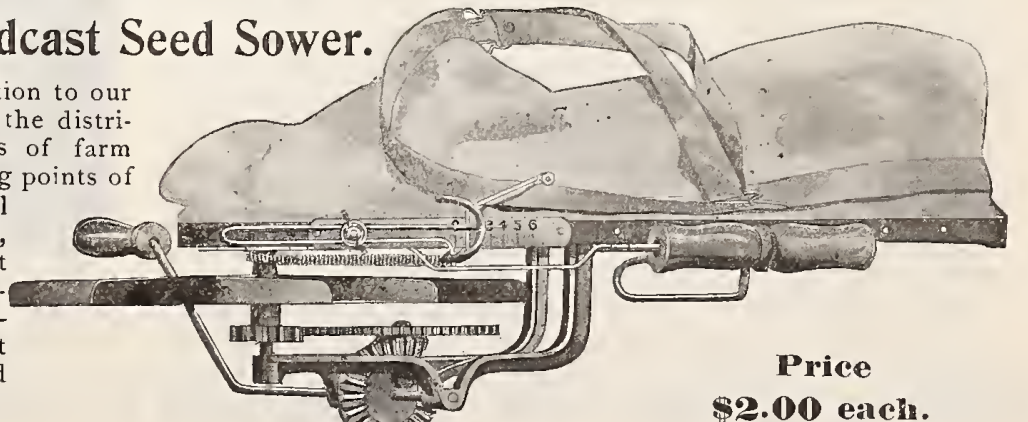

\$2.00 each. 


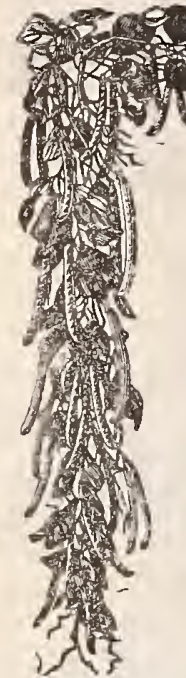

Mammoth Russian Sunflower. The sunflower seeds are superior food for poultry. The plant affords efficient protection from malaria, and should be liberally planted in hedges about the house and in all districts where this insidious disease prevails. Lb. $25 \mathrm{c}$, postage paid; by express, 5 lbs. 50 c, 100 lbs. $\$ 6$.

Improved Georgia Chufas. (For hogs.) A species of "grass nut" much used to fatten hogs. Plant in April ten to twelve inches apart, in two and one-half to three feet rows. Should be soaked before planting. One peck of seed per acre. Lb. 35c, postage paid; pk. $\$ 1.25$; bu. $\$ 4.50$.

Buckwheat, Silver Hull. Sow one and one-half bushels to the acre. Lb. $20 \mathrm{c}$, postage paid; by freight, pk. $50 \mathrm{c}, \mathrm{bu} . \$ 1.50$.

\section{Cotton Seed.}

Hawkins' Extra Prolific Cotton. Earliest, most prolific, easiest picked, most superior lint and finest staple, tall grower, long tap root, resisting drouth; from two to four limbs near the surface, branching; two short limbs together all the way up to the top, all literally covered with bolls. Large boll, small seed, light gray or dark green, yielding from thirty-nine to forty-one per cent., opens well, growing much taller than other varieties, giving every advantage over other varieties in yield per acre. With judicious manuring, quick and rapid culture up to fruiting time, cotton will grow two bales per acre planted in Hawkins' cotton seed. Pk. 50c, bu. $\$ 1.50,5$ bu. $\$ 6.50$.

King's Improved Cotton. Shown by results the past season, this is one of the best kinds to plant in this section, either in bottom or hill land. Owing to its peculiar branching habit it is a very prolific variety. With its small seed will give more lint than than any other sort, yielding from 1,200 to 1,800 pounds seed cotton to the acre, according to the soil; extra early and can be planted as late as July 1st; will mature good crop. Pk. 50c, bu. $\$ 1.25,5$ bu. $\$ 0 \overline{50}$.

Peerless. Very prolific, early; planted in June, will mature fully in average cotton sections. Long limbs, short joints, small white gray seed. Popular in all sections. Plant it once and you will continue to do so. Pk. 50 c, bu. $\$ 1.25,5$ bu. $\$ 5.50$.

Eclipse Long Staple. Extra long staple, lint fine, productive. Pk. $50 \mathrm{c}$, bu. $\$ 1.25,5$ bu. $\$ 5.50$.

Russell Big Boll. Extremely large boll; storm-proof, easy to gather, productive. $\mathrm{Pk}$. $50 \mathrm{c}$, bu. $\$ 1,5$ bu. 4.50 .

New Century Cotton. Differing from all the other long staples, the new century has very small seed, in fact, the seed is as small as the King's Improved, and in consequence it is far more prolific than either Davis, Allen and other well known long staples. Lb. $30 \mathrm{c}$, postage paid; by freight, pk. 75c, bu. $\$ 2$.

BRY
Blue GoOSe...
....Stock Peas
Best variety to plant in
the corn; produces more
peas and hay than any
other variety.

Japanese Buckwheat. This new variety is early and ry productive. The kernels are twice the size of any buckwheat. Owing to its branching character,

Spanish Peanut-Earliest variety grown. Pods express, 4 lbs. 60c, 10 lbs. or over, 12c per lb., bu. $\$ 2$. freight, 5 lbs. 50c, 100 lbs. $\$ 7$.

Virginia White Seed Peanuts. Lb. 25c, postage aid; by freight, 5 lbs. $50 \mathrm{c}, 100$ lbs. $\$ 7$.

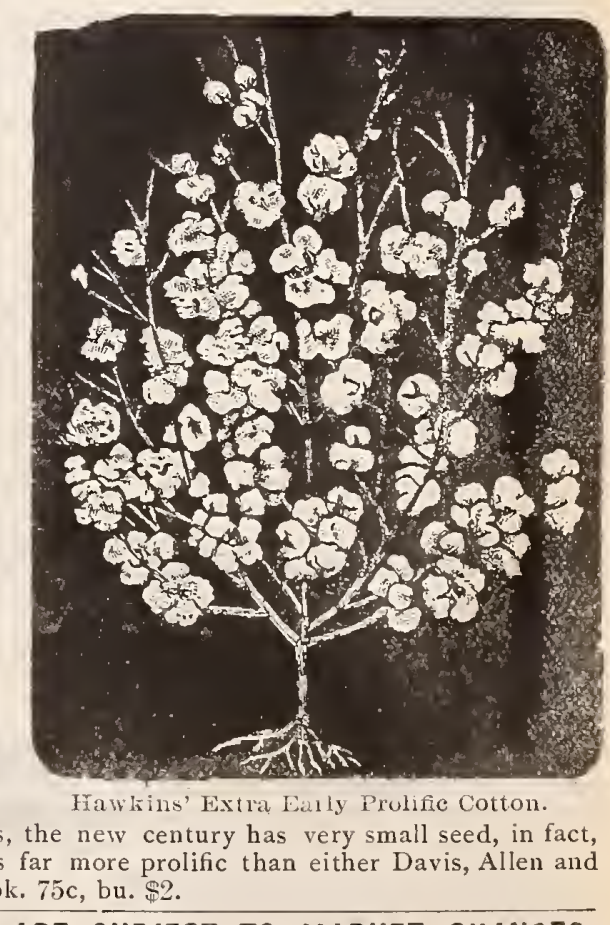

PRICES ON ALL CLOVER, GRASS AND FARM SEEDS ARE SUBJECT TO MARKET CHANGES. 


\section{Fine Seed Corn.}

Do not fail to plant some of our early varieties of seed corn. The past season, all who planted both our Early Yellow and Early White corns made large crops long before the late Southern corns were matured and before drouth set in. Try a few bushels.

Schwill's Ninety-Day Early White Corn. The earliest white field corn in cultivation. Hlanted on or about March 20, it will be ready to gather by July 1. Qt. 30c, postage paid; by freight or express, pk.50c, bu. $\$ 2,2$ bu. $\$ 3.75$, sacks included.

Schwill's Ninety-Day Early Yellow Corn. A bright golden color; medium size ear and cob. It never fails to make a crop, and that too in quick time. Plant this variety if you want early corn on the farm. Qt. 30c, postage paid; by freight or express, pk. 50c, bu. $\$ 1.75,2$ bu. $\$ 340$, sacks included.

Mosby's Prolific. An improved prolific corn which has given splendid results wherever grown. It is a pure white corn; very small white cob and deep, full grain; neither very hard nor very soft. Produces an average of two or three good sized ears to the stalk: Qt. 30c, postage paid; by freight or express, pk. 50c, bu. $\$ 1.75,2$ bu. $\$ 3.30$, sacks included.

Mexican June Corn. A Southern variety that succeeds well planted as an early crop, but is more strongly recommended for later plantings in May or June. It is of quick maturity, and seems particularly adapted to hot, dry weather. The stalks grow eight to fifteen feet high, and it has two or three ears to the stalk. Makes a large yield and a large growth of fodder, and would make an excellent ensilage corn. Qt. 35c, postage paid; by freight or express, pk. $\$ 1$, bu. $\$ 2.50$.

Champion Early White Pearl. An early variety of the Dent family, matures in ninety to one liundred days. Qt. 30c, postage paid; by freight or express, pk. 50c, bu. $\$ 1.50,2$ bu. $\$ 3.00$, sacks included.

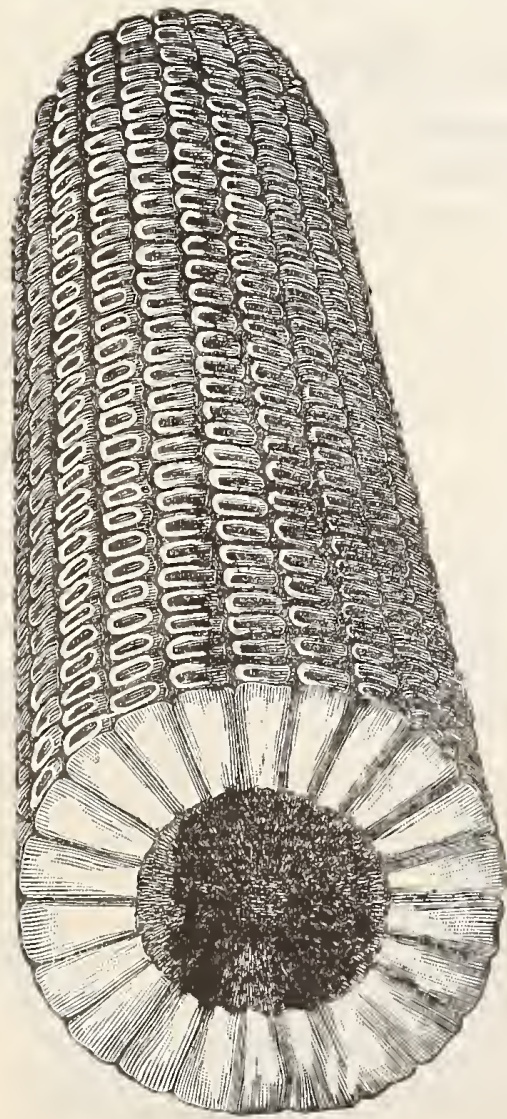

North Carolina White Prolific.

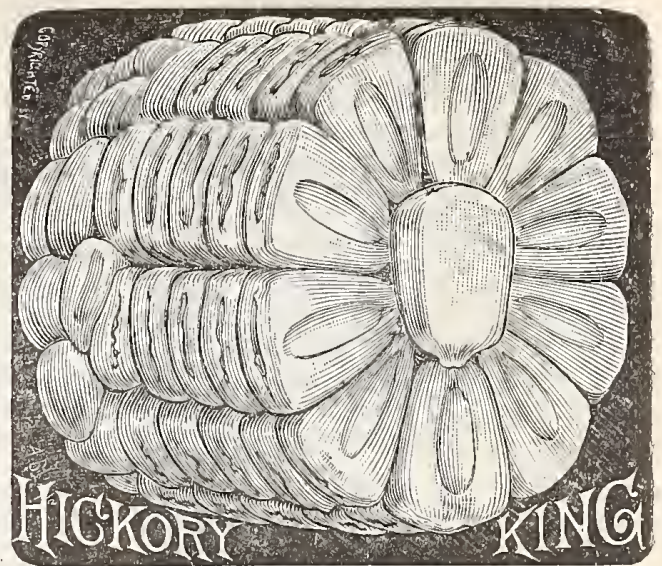

Hickory King. One of the best and most productive white corns in cultivation, especially for high land, and is in great favor with those who have planted it. It produces on good soil three or four average-sized ears to the stalk. The grain is large and beautifully white, making the finest quality meal. The cob is often so small that a large-sized grain will cover the end of it, Qt. 35̃c, postage paid; by freight or express, pk. 75c, bu. $\$ 2.25,2$ bu. $\$ 1.25$, sacks included.

North Carolinia White Prolific. A fine variety of white field corn. It is very hardy and can be planted very early, as well as late. Qt. 35c, postage paid; by freight, pk. $50 \mathrm{c}$, bu. $\$ 1.75,2$ bu. $\$ 3.30$, sacks included.

Dungan's White Prolific. Stalks grow seven to eight feet, ears ten to twelve inches in length, weighing one and one-half pounds, with sixteen to twenty rows of deep, pure white kernels; maturing in about ninety-five days. Qt. 30c, postage paid; by freight or express, pk. 50c, bu. $\$ 2,2$ bu. $\$ 3.50$, sacks included.

Tennessee Mammoth White. A tine native corn, immense ears, stalks large. Qt. 30c, postage paid ; by freight, or express, pk. 60c, bu. $\$ 2.25,2$ bu. $\$ 4$, sacks included.

Iowa Silver Mine. A heavy yielding, large white corn; matures in about ninety days, Qt. 25c, postage paid; by freight, pk. 50c, bu. $\$ 1.50$.

Snowflake White Dent. Ears very large, solid and heavy grains, pure white, full and deep. For an all around, very early, large yielding, fine white corn, we strongly recommend this variety. Qt. 25c, postage paid; pk. 50c, bu. $\$ 1.75$.

IIammoth Cuban White Dent. A large grain with small cob; ears mammoth size and exceedingly heavy. One of the best varieties to stand the drouth as it ripens very quickly. Qt. 30c, postage paid; by express or freight, pk. $50 \mathrm{c}$, bu. $\$ 1.75,2$ bu. $\$ 3.40$, sacks included.

\section{YELLOW DENT VARIETIES.}

Early Mastodon Dent. Large ears and large grains, grows strong, rank and quick. One of the very best early yellow varieties for the South. Qt. 30c, postpaid; by express, pk. 50c, bu. $\$ 1.75$, 2 bu. $\$ 3.30$, sacks included.

New Mortgage Lifter Yellow. Strong, rank grower; an immense yielder; stands the drouth better than most any other sort. Ears always well filled to the ends. A superb variety. Qt. 30c, postage paid; by freight, pk. 50c, bu. $\$ 1.75,2$ bu. $\$ 3.30$, sacks included.

Late Golden Dent. Very large ears, matures in 120 days, deep grain heavy and compact, rank grower. Qt. 25c, postage paid; by freight, pk. 50 c, bu. $\$ 1.75,2$ bu. $\$ 3.30$, sacks included.

Iowa Gold Mine. Ears good size, bright golden yellow ; grain very deep, cob small. Qt. 30c, postage paid; by freight, pk. 50c, bu. $\$ 1.75$, 2 bu. $\$ 3.30$, sacks included.

Improved Leaming. Ninety days. Ears large and handsonie, with deep, large grains; orange yellow color, red cob; stalks medium size, tapering gradually, generally producing two good ears each. Qt. 30c, postage paid; by freight, pk. $50 \mathrm{c}$, bu. $\$ 1.50$, 2 bu. $\$ 2.90$, sacks included. 


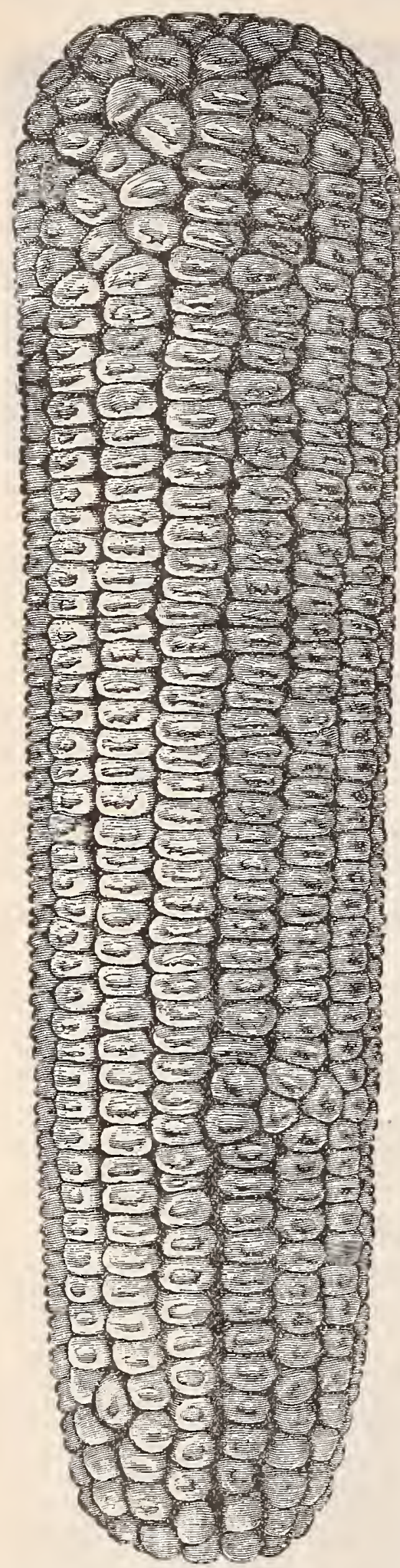

Early Golden Dent Corn.
FINE SEED CORN-Continued.

Extra Early Huron Dent. A fine early yellow sort; deep grains are brightest golden yellow. Matures in eighty-five to ninety days. Qt. 30c, postage paid; by freight, pk. 50c, bu. $\$ 1.75,2$ bu. $\$ 3.30$, sacks included.

Early Butler Dent. Ripens in 80 days. Ears fair size, twelve to sixteen rows; grain golden yellow. Qt. 30c, postage paid; by freight, pk. 50c, bu. $\$ 1.75,2$ bu. $\$ 3.30$, sacks included.

Early Golden Dent. This is one of the earliest and most prolific yellow ninety-day varieties yet introduced; a bright golden color, medium size ear and cob small. Qt. 30c, postage paid; by freight, pk. 50c, bu. $\$ 1.50,2$ bu. $\$ 2.90$, sacks included.

White Cap Yellow Dent. Suitable for all soils. Will produce more corn on poor, thin soil than any kind now in cultivation. Tip ends of the grains are white, inside yellow, making it a beautiful color. Qt. 30c, ostage paid ; by freight. pk. 50c, bu. $\$ 1.75,2$ bu. $\$ 3.30$, sacks included.

Tennessee Mammoth Yellow. A mammoth native variety. Long grains, large ears; very strong grower. Qt. 30c, postage paid; by freight, pk. 60 c, bu. $\$ 2.25,2$ bu. $\$ 4$, sacks included.

Pride of the North. Matures perfectly in eighty-five days; very hardy and prolific; ears of uniform size, cob small. Qt. 30c, postage paid; by freight, pk. 50c, bu. $\$ 1.75,2$ bu. $\$ 3.30$, sacks included.

Golden Beauty. A handsome yellow corn; large ears, broad grains; maturing in from 110 to 120 days. Qt. $30 \mathrm{c}$, postage paid; by freight, pk. 50 c, bu. $\$ 2,2$ bu. $\$ 3.75$, sacks included.

\section{Seed Pop Corn.}

Prices of the following Six varieties: Pkt. 10c, lb. 30c, postage paid ; by freight or express, lb. 20c, 10 lbs. \$1.50.

Monarch White Rice. A superior quality of pop corn, very easily popped and very sweet, tender and white after being popped.

White Pearl. A fine variety; clear, white and productive.

Silver Lace. Pure white, immensely productive.

Queen's Golden. A beautiful golden color, pops extra large.

Red Beauty. A new variety, fine flavor, pops well.

IMapledale Prolific. A new productive variety, pops clear white, large, crisp and sweet.

SHELIED RICE POP CORN FOR PARCHING Price, per 1b. 15e, \$8.00 It will pay you to read some of the following Books which are sent postpaid on receipt of price.

Asparagus Culture-By Barnes and Robinson........................ $\$ 0.50$

Broom Corn and Brooms-A Treatise on Raising Broom Corn..... .50

Cabbages--Gregory ........................................................ $\quad .30$

Cauliflowers-Brill ........................................................... $\quad .20$

Gardening for Profit-Henderson............................................. 2. 2.00

My Handkerchief Garden-Barnard.................................... $\quad .25$

Gregory on Onion Raising-J. J. H. Gregory.......................... $\quad .30$

Truck Farming at the South-A. Oemler ................................ 1.50

Sweet Potato Culture -Fitz .................................................. $\quad .60$

Silos, Ensilage and Silage-Miles ................................... $\quad .50$

New Potato Culture-Carmen .................................................. $\quad .50$

Practical Floriculture-Henderson................................. 1.50

Play and Profit in My Garden-E. P. Roe.............................. 1.50

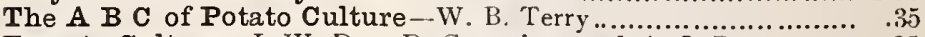

Tomato Culture -J. W. Day, D Cummings and A. I. Root.......... .35

Market Gardening and Farm Notes - Burnet Landreth............ 1.00

Forage Crops Other Than Grasses - Thomas Shaw.. ................. 1.00

The Forcing Book-How to Grow Vegetables Under Grass............ 1.00

The Spraying of Plants................................................... 1.00

Fertilizers-Prof. E. B. Voorhees...................................... 1.00

How to Destroy Insects........................................................... $\quad .20$

Soiling Crop and the Silo-By Thomas Shaw......................... 1.50

Alfalfa-Its Growth, Uses, Etc. F. D. Coburn............................. $\quad .50$

Garden Making-Illustrated ....................................... 1.00

IMushrooms - How to Grow Them. Wm. Falconer....................... 1.00

Peach Culture-By Hon. J. Alexander Fulton....................... 1.50

Onion Culture-T. Grimes................................................... $\quad .50$

Hedges, Wind Breaks, Live Fences, Etc......................... $\quad .50$

The Amateur's Practical Garden Book-Illustrated ................... 1.00

The Principles of Fruit Growing - By L. H. Bailey ................... 1.25

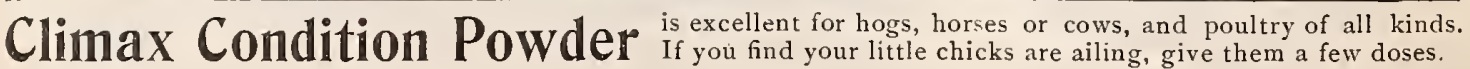




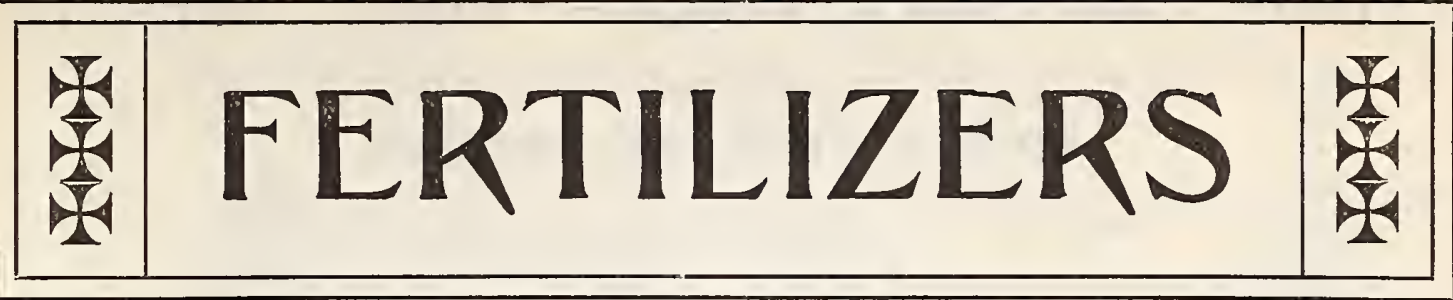

The intelligent and prosperous farmer of the present day is certain to be one who fully believes in and practices that excellent motto: "Feed the soil and the soil will feed you." Crops cannot live and thrive on air and water alone. Their roots penetrate the earth and absorb therefrom the nitrogen, phosphoric acid, potash or other elements of plant food they require. In some form these must be replaced, otherwise your year's work counts for naught. IVe are headquarters for Commercial Fertilizers, and our brands are up to the highest grades and standard required by the State test. We sell by the sack, ton or car load. Special quotations on carload lots.

Schwill's Dissolved Bone Phosphate. Splendid for composting with manure and cotton seed meal. This brand has shown most profitable results on all farm crops. As will be seen by the folluwing analysis it is very high in acid phosphate :

Guaranteed analysis-

Moisture at $212^{\circ} \mathrm{F}$, 12 to 14 per cent.

Water, Soluble, Phos. Acid, 12 to 14 per cent,

Citrate Sol or Reverted Plios. Acid, 2 to 3 per cent. or

Available Phos. Acid, $1+$ to 17 per cent.

Insoluble Phos. Acid. 2 to 3 per cent.

Total Phos. Acid, 16 to 20 per cent.

Bag, 200 lbs. $\$ 1.80$, per ton, 10 bags, $\$ 1650$.

Schwill's Pacific Guano. For all farm, orchard and garden crops. A complete fertilizer containing all the elements of plant food scientifically combined, every ounce of ammonia and phosphoric acid available as plant food. We thoroughly recommend this brand to our customers.

Guaranteed analysis-

Moisture at $212^{\circ} \mathrm{F} ., 12$ to 14 per cent.

Water, Soluble Phos. Acid, 7 to 9 per cent.

Citrate Sol. or Reverted Phos. Acid, 3 to 4 percent. or

Available Phos. Acid, 2 to 3 per cent.

Total Phos. Acid, 12 to 16 per cent.

Nitrogen, 1.65 to 2.50 per cent.

Ammonia, 2 to 3 per cent.

Potash $\left(\mathrm{K}^{2} \mathrm{O}\right)$, Soluble in Water, 2 to 3 per cent.

Bag, 200 lbs, $\$ 3$, per ton, 10 bags, $\$ 24$.

Kainit, Potash Salts. Kainit is a natural product, containing nearly 13 per cent. potash in the most avail able form for plant food. 100 lbs. $\$ 125$, sack, $200 \mathrm{lbs}$. $\$ 2.50$, ton $\$ 22$.

Muriate of Potash. $80 \mathrm{per}$ cent. pure, equivalent to 48 to 50 per cent. actual potash. $5 \mathrm{lbs}$. 40) $25 \mathrm{lbs}$. $\$ 1.25,50$ lbs. $\$ 2,100$ lbs $\$ 3.50$.

Nitrate of Soda. Quick in action, and hastens maturity of crops fully two weeks. $5 \mathrm{lbs} .40 \mathrm{c}, 25 \mathrm{lbs}$. $\$ 1.50$, 50 lbs. $\$ 2,100$ lbs. $\$ 3.50$.

Pure Bone Meal. Invaluable for top dressing lawns. Nothing is better for fertilizing young fruit trees, etc. 5 lbs. 30c, 10 lbs. 40c. 25 lbs. $\$ 1,50$ lbs. $\$ 1.50,100$ lbs. $\$ 2.50,200 \mathrm{lb}$. bag, $\$ 4.50$.

Bowker's Food for Flowers. Clean to handle; without odor, produces rich, green growth and profusion of flowers. Pkt. $20 \mathrm{c}$, by mail $30 \mathrm{c}$.
Schwill's Potash Compound. High grade corn and cotton grower. From the analysis it will be noted that this brand runs unusually high in plant food. A splendid all-round corn, cotton, potato and grain grower.

Guaranteed analysis-

Moisture at $212^{\circ} \mathrm{F}, 12$ to 14 per cent.

Water, Soluble, Phos. Acid, 8 to 10 per cent.

Citrate Sol. or Keverted Phos. Acid, 2 to 3 per cent. or

Available Phos. Acid, 10 to 13 per cent.

Insoluble Phos. Acid, 2 to 3 per cent.

Total Phos. Acid. 12 to 16 per cent.

Potash $\left(\mathrm{K}^{2} \mathrm{O}\right)$ Soluble in Water, 4 to a per cent.

Bag, 200 lbs. $\$ 2.25$, per ton, 10 bags, $\$ 18.50$.

Schwill's Vegetable Fertilizer. The best for all garden truck. A positive benefit to the crop, being unusually high in plant food. Produces results quickly and in abundance; causes a vigorous and rapid growth.

Guaranteed analysis--

Moisture at $212^{\circ} \mathrm{F}, 12$ to 14 per cent.

Water, Soluble, Phos. Acid, 3 to 5 per cent.

Citrate Sol. or Reverted Phos. Acid, 2 to 3 per cent. or

Available Phos. Acid, 5 to 8 per cent.

Insoluble Phos. Acid, 5 to 7 per cent.

Total Phos. Acid, 10 to 15 per cent.

Nitrogen, 2.47 to 4.12 per cent.

Ammonia, 3 to 5 per cent.

Potash ( $\left.\mathrm{K}^{2} \mathrm{O}\right)$ Soluble in Water, 8 to 10 per cent.

Potash as Sulphate, 16 to 20 per cent.

Bag, 200 lb. $\$ 3.50$, ton, 10 bags, $\$ 28$.

Land Plaster or Gypsum. Is largely used as a fertilizer for clover and grasses. 50 lbs. $65 \mathrm{c}, 100 \mathrm{lbs} . \$ 1.00$, $200 \mathrm{lb}$. sack $\$ 1.25$, ton, $\$ 10$.

Pulverized Sheep Manure. One of the best manures to mix with soil for potting plants. As a lawn top dressing it is unequaled. $5 \mathrm{lbs} .30 \mathrm{c}, 10 \mathrm{lbs} .50 \mathrm{c}, 25 \mathrm{lbs} .51$, 50 lbs. $\$ 1.50$.

Jadoo Liquid. It is both food and drink to plants of all kinds. Can be used either on plants grown in the earth or in Jadoo fibre. Pt. bottle 25c. Can not be sen [ by mail.

Walker's Excelsior Plant Food. Has no odor whatever, and can be used dry or dissolved in water for sprinkling. Use it and your flowers. palms, etc., will grow vigorously. Small pkg. 20c, large pkg. 35c; by mail add 5c for postage.

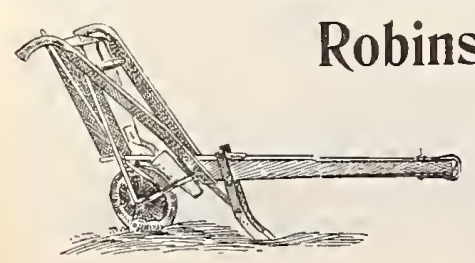

Will fit or can be attached to any plow stock. Will put out any quantity of fertilizer to the acre. The best, cheapest and simplest machine on the market. Nothing complicated about it. A boy can use it. This splendid machine can also be used to drop and drill Stock Peas, etc. Price, $\$ 4.50$ each. 


\section{Poultry and Stock Foods-Insect Powders.}

Ask or send for descriptive circulars of any of the special kinds here listed.

\section{Poultry Food and Supplies.}

Schwill's Mixed Chicken Feed, per sack 100 lbs.....\$1.75 Crescent Chick Food, per sack 50 lbs....

Darling's Beef Meal.

Darling's Beef Scraps

Granulated Bone Meal..

Mica Crystal Grit

Mica Crystal Grit, chick size..

Pioneer Clover Meal.

Cut Clover Hay.

Linseed Meal

Sunflower Seed

Kaffir Corn.

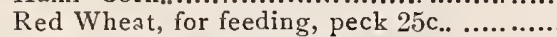

Crushed Oyster Shell

Crushed Oyster Shell, fine.

Rust's Egg Producer:

1 lb. package

$2 \frac{1}{2} \mathrm{lb}$.

6 lb. box

$10 \mathrm{lbs} .100 \mathrm{lbs}$.

$\$ .40 \$ 3.00$

$\begin{array}{rr}.40 & \$ 3.00 \\ .40 & 3.00\end{array}$

$\begin{array}{ll}.40 & 2.50\end{array}$

$\begin{array}{ll}.25 & 1.00 \\ .25 & 1.50\end{array}$

$.50 \quad 3.00$

$.50 \quad 3.00$

$.50 \quad 4.00$

$.75 \quad 4.50$

$.50 \quad 2.50$

1.50

$.25 \quad 1.00$

.251 .50

$10 \mathrm{lb}$.

Rust's Havens Climax Condition Powder :

13 oz package.

$32 \mathrm{oz}$.

$5 \mathrm{lb}$. box

$8 \mathrm{lb}$.

Rust's Havens Roup Pills :

Small box..

Large box

Pratt's Poultry Food:

$26 \mathrm{oz}$. pack age

$5 \mathrm{lb}$.

12 lb. bag..

.25

.50

1.00

1.50

.25

.50

1.00

1.50

.25

1.00

.25

.60

1.25

Wilbur's Egg Food, 2⿺辶 lb. package. $\$ .25$

Wilbur's Sure Louse Killer, package................. . .25

Conkey's Egg Food and Tonic, package .............. .25

International Poultry Food:

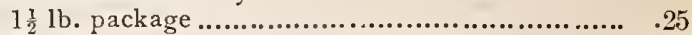

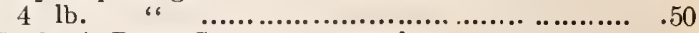

Conkey's Roup Cure, guaranteed :

Small size........................................... .50

Large size.............................................. 1. 1.00

Royal Poultry Food, 2 lb. package.................. .25

Lambert's Death to Lice Powder:

$5 \mathrm{oz}$. package................................... . 10

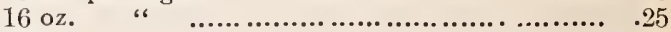

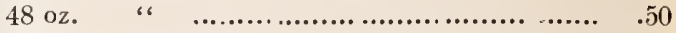

$100 \mathrm{oz} . \quad$ " $\quad$..................................... 1.00

Lambert's Death to Lice Ointment :

1 oz. package......................................... . .15

$3 \mathrm{oz.}$ " $\quad$ "..................................... .25

$5 \mathrm{oz} . \quad$ “ special.................................. .40

Excelsior Liquid Lice Exterminator, gallon.......... 1.00

Sheridan's Condition Powder :

$4 \mathrm{oz}$. package........................................ .25

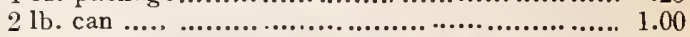

Uncle Ben's Antiseptic Nest Eggs, dozen........... 1.00

China Nest Eggs, dozen............................ . 40

Patent Stoneware Drinking Fountain:

$\frac{1}{2}$ gal. size......................................... .25

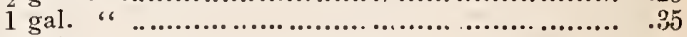

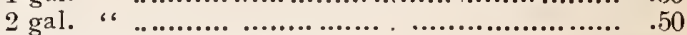

Jug Shaped Drinking Fountain:

$\frac{1}{2}$ gal. size......................................... .35

1 gal. " "......................................... .50

\section{Stock Food.}

Pratt's Food for Horses and Cows:

Small package........................................ $\$ .25$

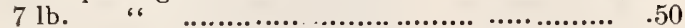

$12 \mathrm{lb}$. bag ......................................... .75

$25 \mathrm{lb}$. "

International Stock Food:

$1 \frac{1}{2} \mathrm{Ib}$. package .................................... .25

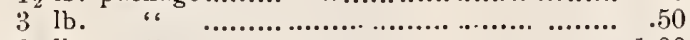

6 lb. « $\quad$ «................................... 1:00

25 lb. pail ........................................... 3.50

Wilbur's Stock Food, package........................... . .25
International Calf Fattener, $50 \mathrm{lb}$. pails

Colic Cure, per package............... 1.00

Gall Cure "، $\quad$................. .25

Healing Oil " "

Heave Cure " " $\quad$.................. .50

Worm Powder "، $\quad$................ 50

Harness Soap "، $\quad$.................. .... .25

Honey Tar Foot Remedy............... . .50

Bo-Ko Cholera Cure, package............................ . .25

Pratt's Dog Biscuit, $1 \mathrm{lb} \ldots \ldots \ldots \ldots \ldots \ldots \ldots \ldots \ldots \ldots \ldots \ldots . . .15$

10 lbs............................................... 1.00

\section{Insect Powders.}

Hammond's Slug Shot:

1 lb. cartoon....

5 lb. package..

.$\$ .35$

$10 \mathrm{lb}$.

Bulk, per 100 ibs.

English Compound for Potato Bugs :

100 Ibs.

10 lbs.

Paris Green :

1 lb. package..

$5 \mathrm{lb}$.

Bulk, 25 lbs, per lb.

$100 \mathrm{lbs}$, per lb.

Paragrene:

$\frac{1}{2}$ lb. package.

$1 \mathrm{lb}$.
Bug Death :

1 lb. package...............\$ .25

3 Ib.

$5 \mathrm{lb}$.

$12 \frac{1}{2}$ lb. box

$100 \mathrm{lb}$. keg.

3.00

.18

.16

Whale Oil Soap, 1 lib. pkg...... .25

Fir Tree Oil Soap, $\frac{1}{2}$ lb. Ein.... .25

Sulpho Tobacco Soap, $\frac{1}{2}$ lb.pkg $\quad .25$

Scrofularia Powder, pkg.........

Copperdine, box

Cattle Comfort, quart can.

.35

烈

Tobacco Extract, pint can................ .35

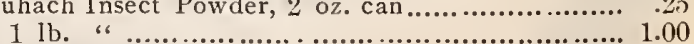

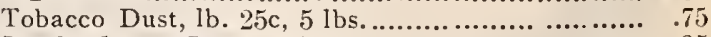

Jowder 1nsect Powder Gun.............................. . .25

A I PRICES quoted on this page are F. o. Br. Memphis. We do not send Ponltry Supplies or Insect Powders through the mail. They must go by express at purchaser's expense. 


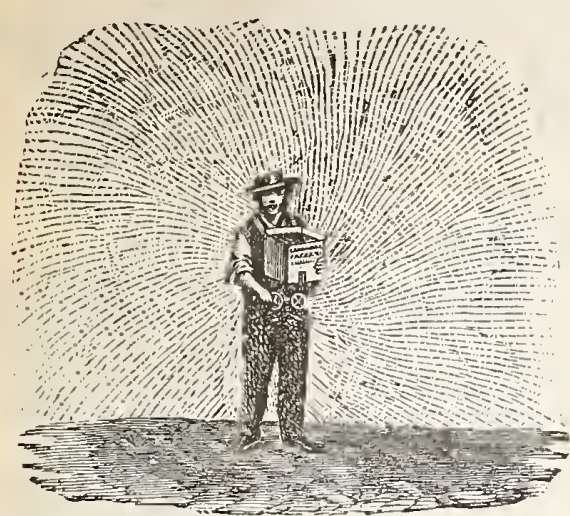

Cahoon Broadeast Seed Sower.

Asparagus Knife.

English Saw Blades..............each $\$ 1.25$

American.

" $\quad .75$

Baskets.

Standard, 1 bu., stave...........doz. 1.50

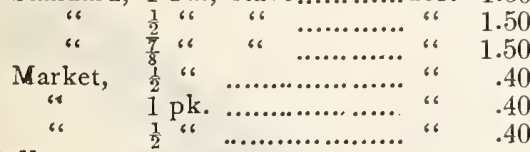

Bellows.

Woodason's Single Cone..........each 2.00

Bee Smokers.

Clark's Improved

Calf Weaners.

Rice's

Corn Planters, Hand.

Eagle ............................. " 1.50

Segement........................... " 1.50

Cultivators, Garden.

Diamond Complete............... “ 4.00

Dibble.

All Iron

Drill, Hand.

Garden Acme

Fruit Picker.

Wire

Fork.

Transplanting

Hot Bed Sash.

Glazed, $3 \times 6$.

Huskers.

Corn ............

Humphrey's Concave........... " . 35

Mats, for Covering Sash.

Jute, $76 \times 76$

Mole Traps.

The Reddick Improved .......... " 1.25

Little Giant, very strong.......... " " 1.00

"Out o' Sight" ................... " 1.00

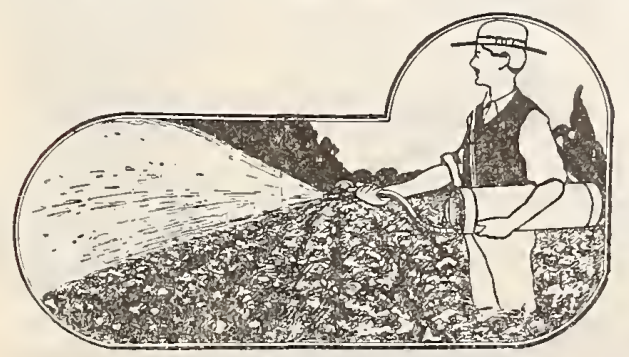

Au to Compressed Air Sprayer.

\section{GARDEN TOOLS, ETC.}

Moss, Spagnum.

Per 1 Bbl. Bag.

Moth Catcher.

Hazeltine's, small size........... " 1.00

Mowing Knife Grinders.

large " ............. " 1.25

Bi-Pedal.

Measures.

Wooden, Iron Bound, 1 qt...... " . .11)

"6 "6 "6 2 " ...... "6 $\quad .15$

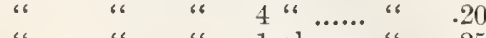

$1 \mathrm{pk} \ldots . .$. " $\quad .25$

Tree Protecting Band.

Pillar Catter ...................per yd.

Pruners, Tree.

Waters' Improved, $10 \mathrm{ft}$. pole, each 1.75

Little Giant with Saw Att'chm't " "

Chisel and Saw Attachment..... " "

Shears, Long Handlèd, Heavy

Plant Duster.

Tin, 1 gal.

Norton's Improved.

Raffea.

For tying. per lb.

Strawberry Boxes.

Quarts .........................per $1000 \quad 3.00$

Crates.............................." 1008.00

Seed Sowers.

Cahoon Improved...............each 3.25

Little Giant.......................... " 2.00

Columbia......................... " 2.00

Sprayers.

Knapsack, Myers................ " 7.50

Rochester Compressed Air...... " " 4.00

Auto Spray Compressed Air..... " 5.00

Imperial Brass Bucket Pump... " “ 3.50

Lever Barrel Pump............... " " 12.00

Daisy Force Bucket Pump ...... ، $\quad 1.50$

Faultless Hand..................... " " .75

Perfection "s .................... " " $\quad .75$

Sure Thing........................ "

Rubber and Atomizer.............. " $\quad .75$

Syringe, Brass.

For Fine Sprinkling............ " 4.50

Sprinkler, Rubber.

Scollay's Angle Neck

" Straight Neck.......... " " 1.00

Thermometers.

Plain Top .............. " $\quad .75$

8 Inch............................ " $\quad .30$

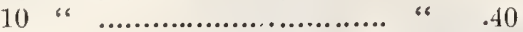

Porcelain ........................... " " 1.50

Self Registering ................... " " 3.00

Trowels.

English Forged Steel.............. " $\quad .50$

Best American Steel......... " " $\quad .25$

Ordinary Garden............... " " .15

Ladies' Floral................ " " .25

Transplanting Long Blade.. “ $\quad .25$

Twines.

Jute, 2-ply, 1b. 15c, 100 lbs. @ 12c 3 -ply, “ 15c, 100 " (a) $12 \mathrm{c}$ Binder, $5 \mathrm{lb}$. ball each $75 \mathrm{c}, 100 \mathrm{lbs}$. $\$ 14$ Weeders, Hand.

Lang's Improved ..............each $\quad .25$

Hazel tine................... " $\quad .25$

Excelsior......................... " $\quad .25$

Combination ................... "

Cleveland Lawn Weeder.... " $\quad .75$

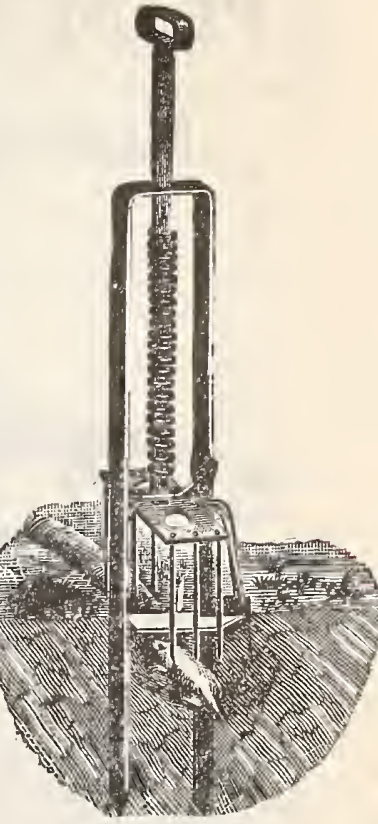

Reddick Improved Mole Trap.

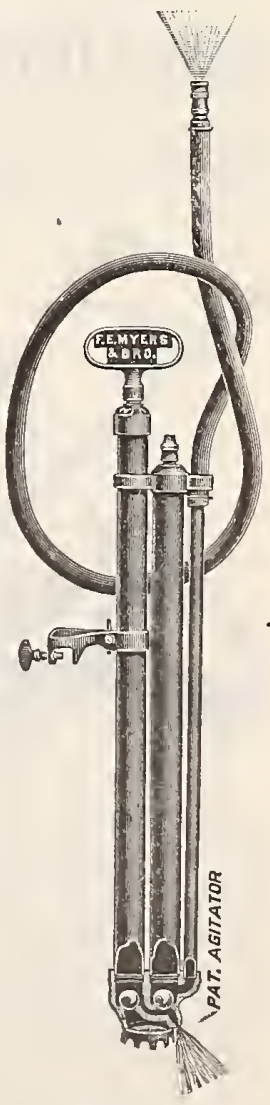

Imperial Bucket Spray Pump. 


\section{PLANET JR. GARDEN TOOLS}

We wlll gladly send a fully illus: trated catalogue to any one who desires it, and can supply prompt. desirosit, and can supply prompt. ly any thing ordered. Planet $J r$. the market. Our prices the lowest.

\section{Planet Jr. Cultivators, Horse Hoes and Harrows.}

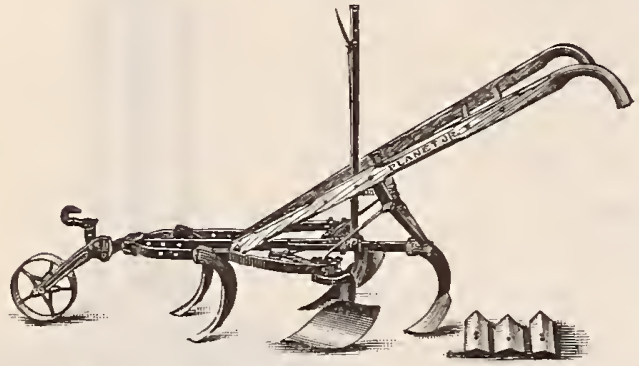

Planet Jr. No. 9. Horse Hoe and Cultivator.

Planet Jr. No. 8 Horse Hoe. This standard horse hoe is used everywhere. It is the best made and most serviceable horse hoe in the market. It has every modern improvement. Every part is perfected to make the tool acceptable to the intelligent farmer, who knows the best is always the cheapest. Price, \$8.50.

Planet Jr. No. 9 Horse Hoe and Cultivator. This tool is similar to the No. 8 horse hoe, but it has a plain wheel instead of one operating by a convenient lever. It has the same standards and teeth, and is made in other respects like the popular No. 8. It is strong and serviceable and will give full satisfaction. Price, $\$ 7.40$.

Planet Jr. No. 4 Horse Hoe and Cultivator. Without wheel, $\$ 5.60$; with wheel, $\$ 6.35$.

Planet Jr. No. 4 Plain Cultivator. Wiı hout wheel $\$ 4.25$; with wheel, $\$ 5.00$

Planet Jr. No. 5 Horse Hoe and Cultivator. Complete, $\$ 6.50$.

Planet Jr. Twelve-Tooth Harrow Cultivator. This tool has rapidly grown in favor with farmers and market gardeners. It has a high frame and the chisel shaped teeth cut an inch wide. It may be set with teeth trailing. Price, plain, $\$ 5.80$; with wheel, $\$ 6.90$; com. plete, $\$ 8.50$.

\section{Garden Drills and Cultivators}

Planet Jr. No. 1 Combination Drill and Wheel Hoe, Cultivator, Rake and Plow. Has a complete set of cultivating tools. Hopper holds a quart. Each $\$ 9.50$.

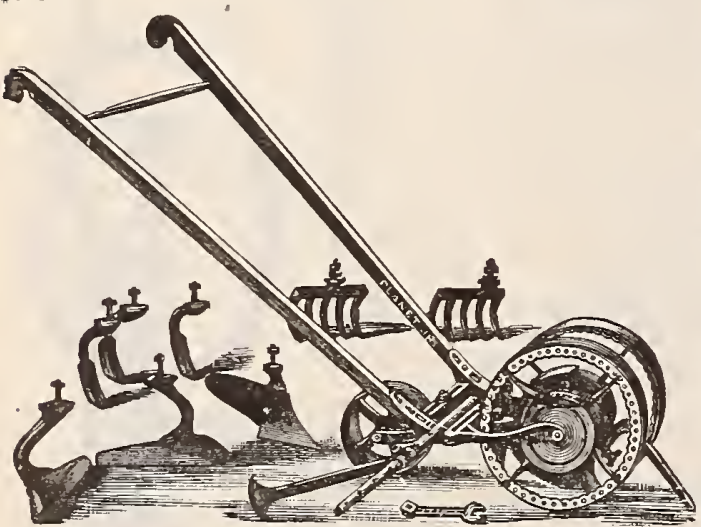

Planet Jr. No. 1 Combined Drill and Wheel Hoe.

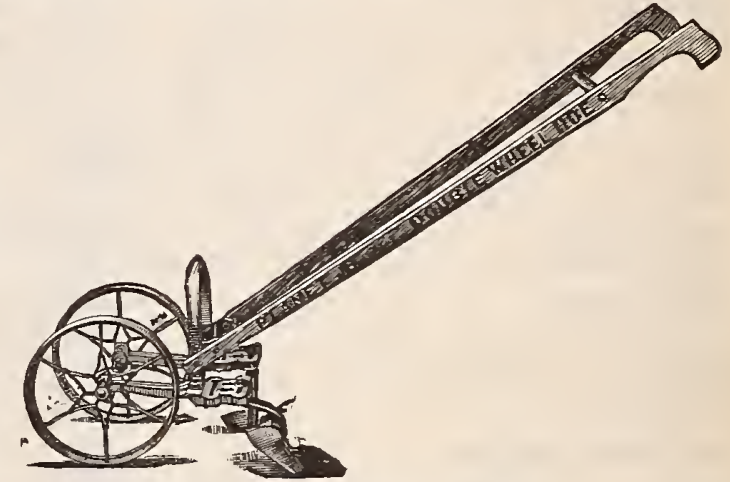

Planet Jr. No. 13 Doubie Wheel Hoe.

Planet Jr. No. 2 Seed Drill. Holds $2 \frac{1}{2}$ quarts. Known the world over. Each $\$ 7.50$.

Planet Jr. No. 3 Hill Dropping Seeder. Drills accurately, also drops seed $4,6,8,12$ or 24 inches apart. Each $\$ 10.50$.

Planet Jr. No. 4 Combined Hill Dropping Seeder. Holds three pints, has force feed and sows and covers any depth desired, but its distinctive feature is that it not only sows in drills, but also drops in hills $4,6,8$ or 12 inches apart. Grand and useful implement. Each $\$ 10.50$. As a drill, $\$ \$ 3.50$.

Planet Jr. No. 5 Hill and Drill Seeder. Sows accurately any lind of seed. Price $\$ 13$.

Planet Jr. No. 11 Double Wheel Hoe, complete, $\$ 9.00$

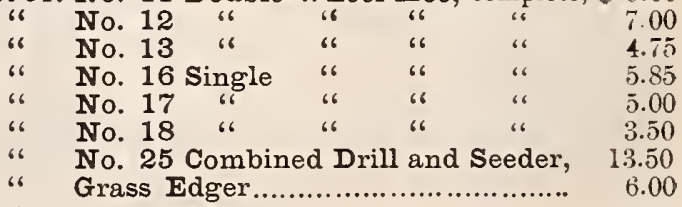

Fire-Fly Garden Plow. Makes the care of a vegetable garden a pleasure, and 10,000 families who could not find time to keep a garden, if attempting its cultivation with the ordinary hand hoe, can raise their own vegetables successfully with the "Fire-Fly." Each, complete, $\$ 2.35$.

Farmers' Friend No. 19 Garden Cultivator. Strong and well made; an effective tool for all kinds of garden work. Strength, variety of tools and cheapness are its great virtues. Price, each, $\$ 375$.

Our Net Prices Fifty Cents Less on each ' Cool than the Planet Jr. regular prices.

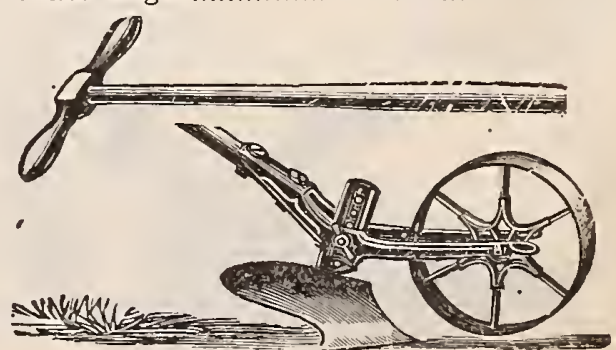

Fire-Fly Garden Plow. 


\section{FLOWER POTS, BULB PANS, ETC.}

The following prices are net. No discount. Packing free, which we do under our own supervision, but we are not responsible for any breakage. No goods sent C. O. D.

Standard Flower Pots.

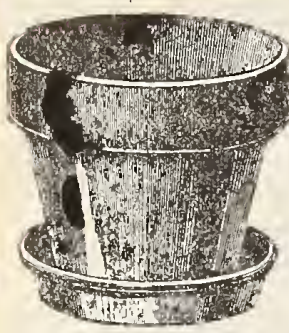

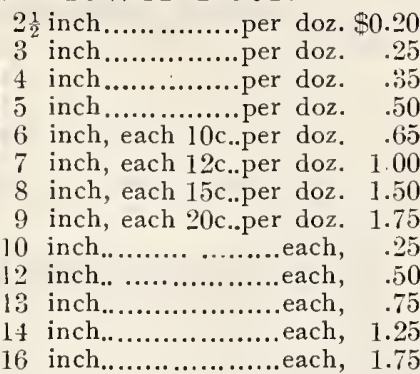

Standard Flower Pot. 18 inch

\section{Seed or Bullb Pans.}

6 inch.............................................each, $\$ 0.15$

8 inch.........................................each,

12 inch...........................................each,

14 inch............................................each,

\section{Fancy Rustic Pots.}

These are fluted and painted.

6 inch, with saucer.

each, $\$ 0.20$

7 inch, with saucer...

each,

.30

8 inch, with saucer. each

\section{.25 \\ .40 \\ .50}

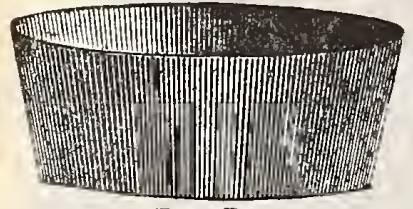

Fern Pans.

$4 \frac{3}{4}$ inch ......each, $\$ 0.10$ 5 inch .......each, .15 $6 \frac{1}{4}$ inch......each, .20 8 inch......each, $\quad .30$ Fern Pan.
10 inch......each,

\section{Flower Pot Saucers.}

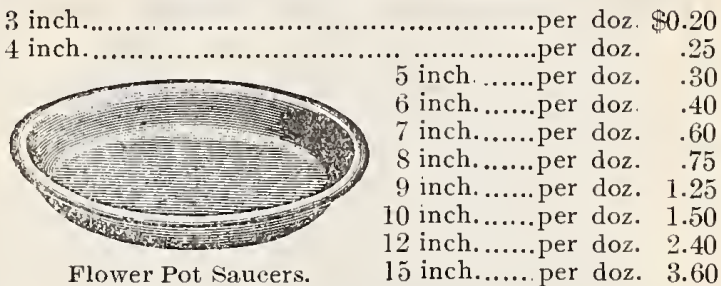

\section{Bulb Pots.}

$3 \frac{1}{2}$ inches deep, 6 inches wide. each, $\$ 0.15$

5 inches deep, 7 inches wide.

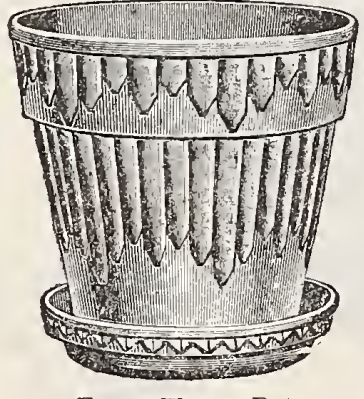

Fancy Flower Pots.

\section{Fancy Flower Pots.}

These are handsome decorated pots, with saucers to match ; fluted and figured, very attractive and desirable for plants that are to be kept indoors.

4 in., with saucer each, $10 \mathrm{c}$ 5 in., with saucer each, $15 \mathrm{c}$ 6 in., with saucer each, $20 \mathrm{c}$ 7 in., with saucer each, $25 \mathrm{c}$ $S$ in., with saucer each, $30 \mathrm{c}$

Fancy Rustic Boxes, with inside lining for ferns, 75c Fancy Pansy Pans, with inside lining............. 75c Fancy Decorated Fern Pans, with inside lining... 75c Fancy Hanging Baskets, decorated, 6 inch......... 30 Fancy Hanging Baskets, decorated, 8 inch. ....... $40 \mathrm{c}$

\section{ESCULENT R00TS AND PLANTS.}

\section{ASPARAGUS ROOTS.}

It pays to have a small bed of asparagus so as to gather it fresh from your garden, and when once set, a bed will last many years. Ask for circular giving directions for planting, etc.

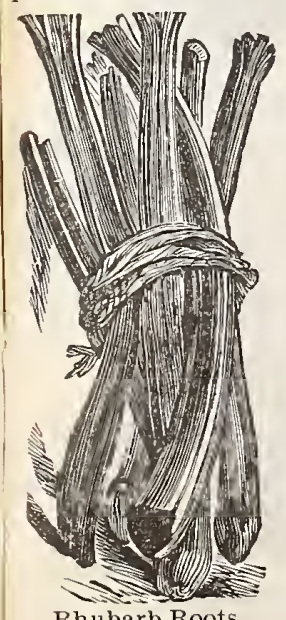

Rhubarb Roots.
Palmetto. An improvement on Conover's, in that it yields a much heavier crop and of much more even and regular size. Large 2year-old roots, 50 for $75 \mathrm{c}, \$ 1$ per 100 , $\$$ i per 1000 .

Giant Argenteuil. Earlier, more prolific and larger than Palmetto. A superior new variety. 2 -year-old roots, $50 \mathrm{c}$ for $100, \$ 1.50$ for $100, \$ 10$ per 1000 .

Conover's Colossal. Large 2 -year-old roots, 50 for $50 \mathrm{c}, 75 \mathrm{c}$ per 100, $\$ 6$ per 1000 .

Hop Vines. A few hop vines are nice on any place, for making yeast, etc. They are a profitable and staple crop. $25 \mathrm{c}$ each, 5 for $\$ 1$, by express only.

Asparagus roots must go by express at purchaser's expense

\section{ARTICHOKE PLANTS.}

Green Globe. The standard variety ; produces large globular heads. Fine strong plants. Each 20c, doz. \$2, by express only.

Jerusalem Artichoke. Enormously productive. Plant during early spring in rows four feet apart, two feet in row. Cut same as you do potatoes, leaving one eye. Three bushels will plant an acre. Qt. $10 \mathrm{c}, \frac{1}{2} \mathrm{pk} .30 \mathrm{c}, \mathrm{pk}$. $50 \mathrm{c}$, bu. $\$ 1.25$; by mail, qt. $25 \mathrm{c}$.

Red Jerusalem Artichoke. Much more productive than the white. Tubers bright red and keep well. Prices same as the foregoing variety.

Sage Plants. Strong, hardy plants of this excellent culinary herb. Each $10 \mathrm{c}, 3$ for $25 \mathrm{c}, 12$ for $75 \mathrm{c}$, exp. only.

Thyme Plants. One-year-old plants, each $10 \mathrm{c}, 2$ for $25 \mathrm{c}, 12$ for $75 \mathrm{c}$, by express only.

Rhubarb Roots. Set the roots three feet apart each way. It requires but little labor. Once planted it will remain in bearing condition for three or four years. Small roots, $50 \mathrm{c}$ a dozen, large clump, $\$ 1.50 \mathrm{doz}$, express only.

Rhubarb Seed. Pkt. 5c, oz. 25c.

Horseradish Sets. Set small end down, so that the top will be two inches below the surface. The soil should be very rich and well cultivated. Doz, $20 \mathrm{c}, \$ 1$ per 100 , $\$ 6$ per 1000 ; by mail, $25 \mathrm{c}$ doz.

Chives or Schnittlauch. Used for seasoning and for cottage cheese. Large clumps $25 \mathrm{c}$ each, by exp. only. 


\section{NURSERY DEPARTMENT}

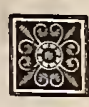

Home grown, acclimated, good healthy trees and plants, our own raising, true to name, and sure to grow if properly handled. Our stock is far better than the little twigs the tree agent charges you double prices for. Send us a trial order and we will guarantee satisfaction.

Terms Cash or satisfactory reference with orders from unknown parties. Our prices will be found all very reasonable. No orders taken for nursery stock for less than $\$ 1$. We do not send plants or trees C. O. D. unless onehalf of the amount accompanies the order.

Packing. All bundles and bales of trees and plants are carefully labeled and packed in damp moss and straw, wrapped so as to carry safely. We are particular on this point, and it will do you good to receive a bundle of our trees.

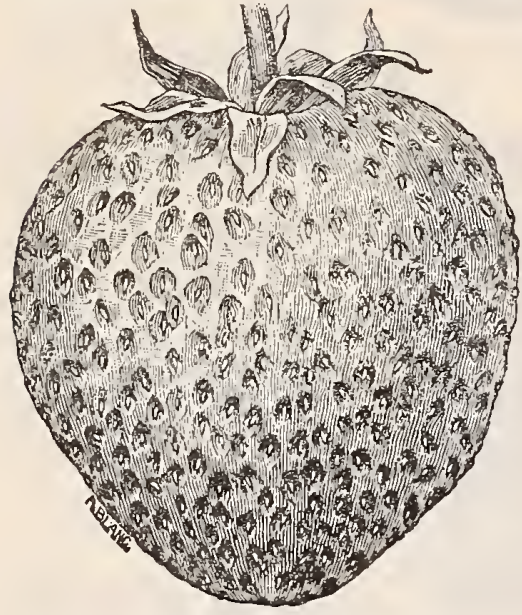

\section{STRAWBERRIES.}

Plant in March, April or May, on good ground deeply worked and well manured. Set in rows three and one-half feet apart, fifteen inches in rows for field culture; fifteen inches each way for garden. Cultivate clean, mulch late in the fall and uncover early in the spring. Remore mulch after fruiting and spade in a light dressing of manure.

New Strawberry, Rough Rider. Originated in New York State. The introducer claims the following points of superiority: Perfect blossom, very productive, extremely vigorous, very large and attractive, the firmest, the very latest, the best keeper, the finest flavor, sells at highest prices. Berries very large, irregular in shape, dark colored as Gandy. McKinley Strawberry.

New Strawberry, McKinley. One of the finest and firmest of the large berries. Makes vigorous, strong, healthy and very productive plants. Berries conical, large, dark red, fine form, high quality and firm. One of the most promising of the recent introductions for both home and market use. Mid-season. 100 for $\$ 1,500$ for $\$ 3.50,1000$ for $\$ 6.50$.

New Strawberry, Sunshine. A record breaker for late market, as late as Gandy and will yield four times as much fruit. 25 for 50c, 100 for $\$ 1.50,500$ for $\$ 5$.

Bubach. A large, dark red berry, productive, mid-season $\$ .75 \$ 4.00$

Brandywine. Large, glossy, crimson fruit, firm and solid,

plant vigorous............................................

Bismark. Very large scarlet, of fine flavor, productive..

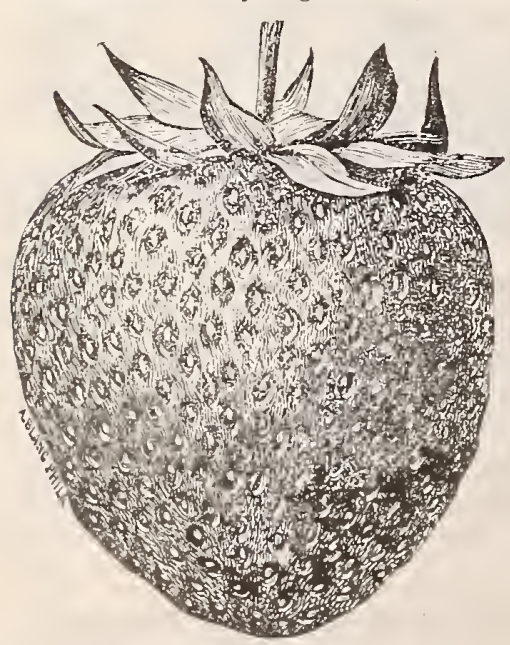

Brandy wine Strawberry. Promises to take its place as the very best late market variety. Plants of this excellent berry were sold last season at $\$ 20$ and $\$ 25$ per 1000 . Our price for strictly reliable plants now is as follows: By express, 100 for $\$ 1,500$ for $\$ 3.50$, 1000 for $\$ 6.50$.

\section{Excelsior.}

New, very early, of good size and color, fine for market..............
$75 \quad 4.00$

$.75 \quad 4.00$

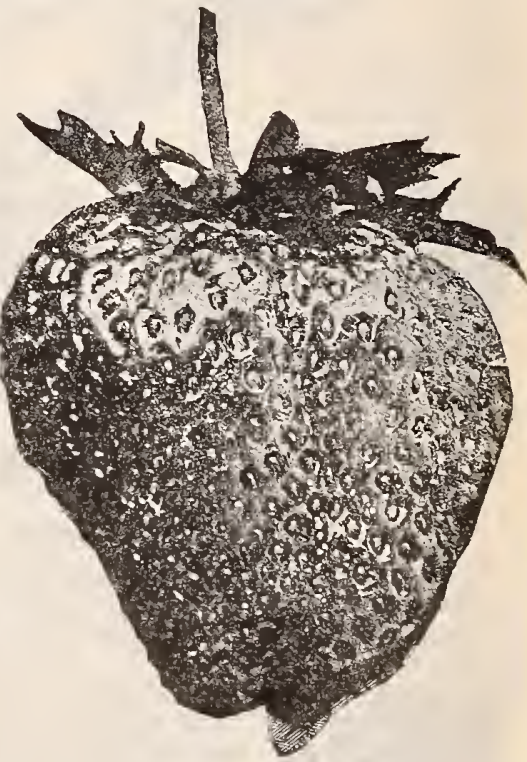

Rough Rider Strawberry .

$100-1000$

$\begin{array}{llr}\text { Crescent. An excellent market variety ..................... \$ } \$ .50 & \$ 3.00 \\ \text { Gandy. A late variety of excellent quality................ } & .50 & 3.00\end{array}$

Hoffman's Improved. Valuable early market variety, of large size and excellent shipping qualities...................

Lady Thompson. One of the very best for the South, plants hardy and vigorous, fruits large and sweet..............

Irichell's Early. Ripens extra early, extensively grown, succeeds in all sections

Plow City. Season late, fruit mammoth in size and at same time exceedingly productive; a genuine novelty of real merit ........................................................

wilson's Albany. An old standard variety, always suc-

Tennessee Prolific. Should be planted by all berry growers, either for market or home use, quality excellent and one of the most productive.

Aroma. Very large, late, succeeds on thin soil better than Gandy, has a fine aromatic flavor ........................
4.00

.50

.50

3.00

3.00

1.00

6.00

.50

3.00

.50

3.00

1.00

\section{ras}




\section{Peaches.}

Price 25c each, $\$ 2.00$ per dozen, except where noted otherwise. All fine, smooth, handsome trees, 4 to 6 feet.

\section{FREESTONES.}

New Peach, Eleanor Semmes. A splendid, large, yellow, freestone peach of the very best quality, ripening in September. We are glad to be able to catalogue this excellent variety. Each 50c, doz. $\$ 4.00$.

Admiral Dewey. A fine, new variety, deep orange yellow, crimson cheek, juicy and melting, freestone, ripens June 15 th. Each $35 \mathrm{c}$, doz. $\$ 3.00$.

Alexander. Flesh white, ripens June 1st to 15 th.

Triumph. Yellow, ripens June 1st to 15 th.

Yellow St. John. Golden yellow, ripens June 20th.

Early Rivers. White, pink cheek, ripens July.

Amelia. Large white, ripens July.

Memphi. Very large, white, red cheek, ripens September.

Crawford's Early. One of the very best peaches, yellow, juicy, ripens August.

Crosby. Clear yellow, ripens August 15th.

Ensley. Crimson yellow, ripens August 15 th.

Stump the World. Large, white, fine, ripens August 15th.

Crawford's Late. Finest quality, ripens August 20th.

Foster. Yellow, cheek red, ripens July 20th.

old Mixon Free. Yellowish white, ripens

August 15th.

Susquehanna. Fine canner, ripens July 31 st.

Hill's Chili. Hardy yellow, ripens September 30 th.

Wonderful. Handsome, productive, ripens October 10 th.

Early Tillotson. White covered, red cheek, ripens June 25th.

Globe. Fine yellow, ripens October.

Mountain Rose. White, splashed carmine, ripens July 1.

Piquet's Late. Flesh yellow, sweet, juicy, ripens September.

Belle of Georgia. Very large, white, ripens July 20th.

Champion. Immense size, skin creamy white, red cheek ripens August.

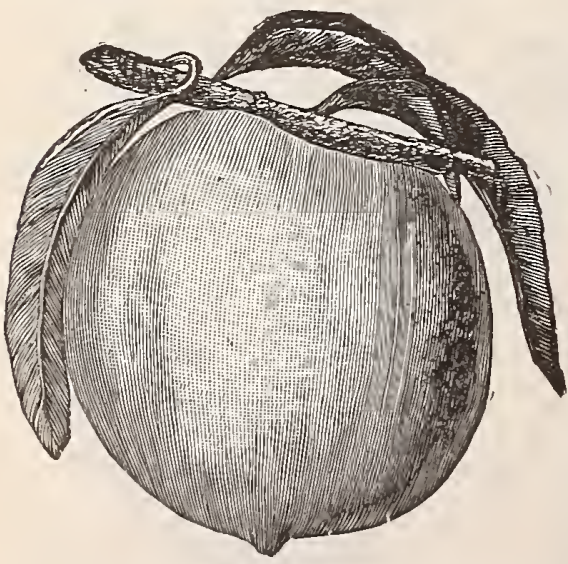

Greensboro Peacb.

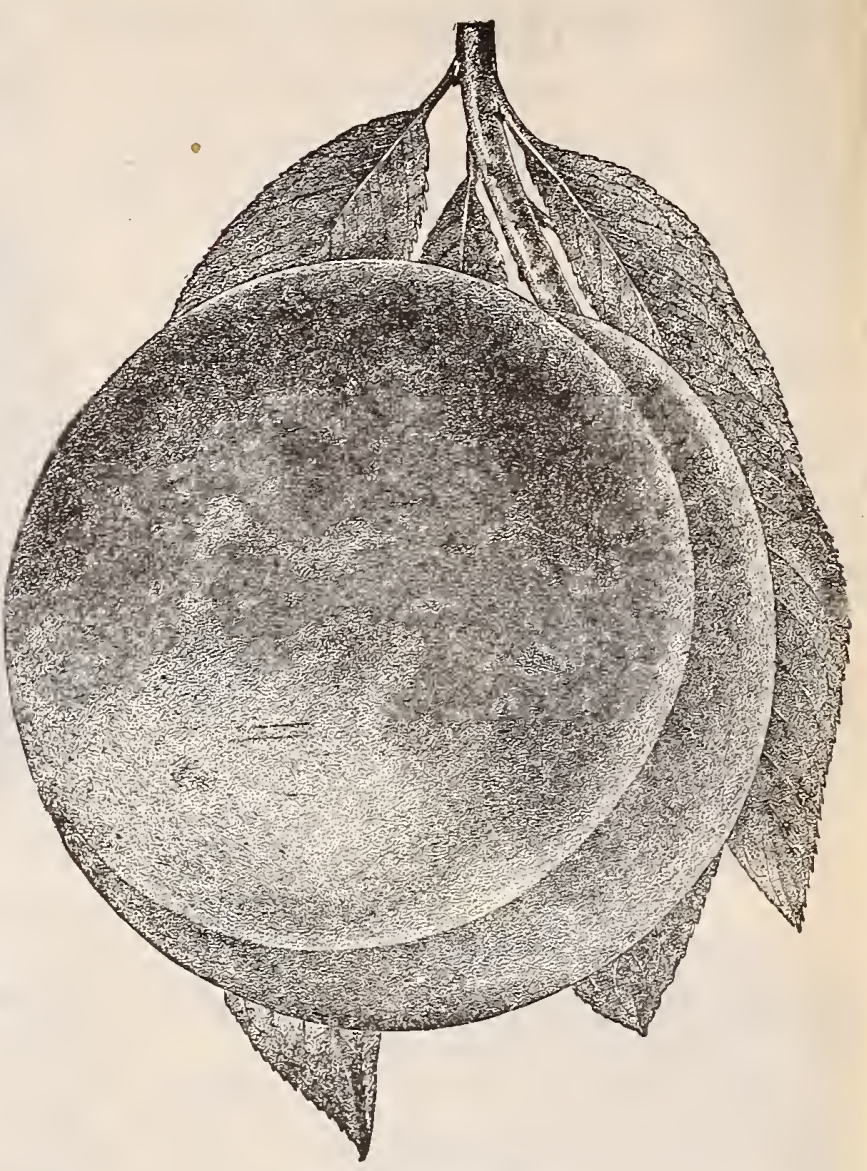

Admiral bewey Peach.

Greensboro. An early variety, ripens June 1st, large, white, juicy, and good quality, half freestone.

Everbearing. Freestone of Indian type, flesh white, streaked with red, continues a long time in bearing, fine for home use. Each, 25c, doz. \$2.50.

Heath Free. Resembles Heath Cling in size and color, very tender, juicy and melting, ripens September.

Matthew's Beauty. A large yellow peach of recent introduction, very showy, and a good keeper, ripens in August.

\section{CLINGSTONES.}

New Peach, Fitzhugh Lee. Large, creamy white, with crimson blush, meltıng, juicy and high-flavored, clingstone, ripens July. Each 40 c. doz. $\$ 3.50$.

Sneed, or Peeble's. Creamy white, half cling, ripens June 10th.

Stonewall Jackson. Very fine, ripens July 15 th.

Lemon Cling. Deep yellow, ripens end of July.

Old Mixon Cling. Yellowish white, ripens August.

Levy's Late. A fine, large, late variety, ripens October.

Heath Cling. Pale yellow, fine, ripens September.

Henrietta. Large, fine quality, ripens September.

Indian Blood. Large, dark crimson, ripens August.

Chinese Cling. Creamy white, ripens July 15 th.

Morris October. One of the best, ripens October 1st.

Nix Late. A large, late clingstone from Georgia, tinged with red, flesh white, very sweet. Each $35 \mathrm{c}$, doz. $\$ 3.50$.

White English Cling. Very large, creamy white, with blush on sunny side, flesh white, very juicy, excellent, ripens August. Each 35 c, doz. $\$ 3.00$. 


\section{Pears. \\ NEW VARIETIES.}

Rossney. A chance seedling grown near Salt Lake City, Utah. Ripens about two weeks Iater than Bartlett, averages larger, excellent keeper and shipper, uniform size, shape and color, one of the handsomest; creamy skin with crimson blush; flesh melting, juicy, sweet and tender, of superior flavor. A vigorous grower, hardy both in wood and fruit bud, and

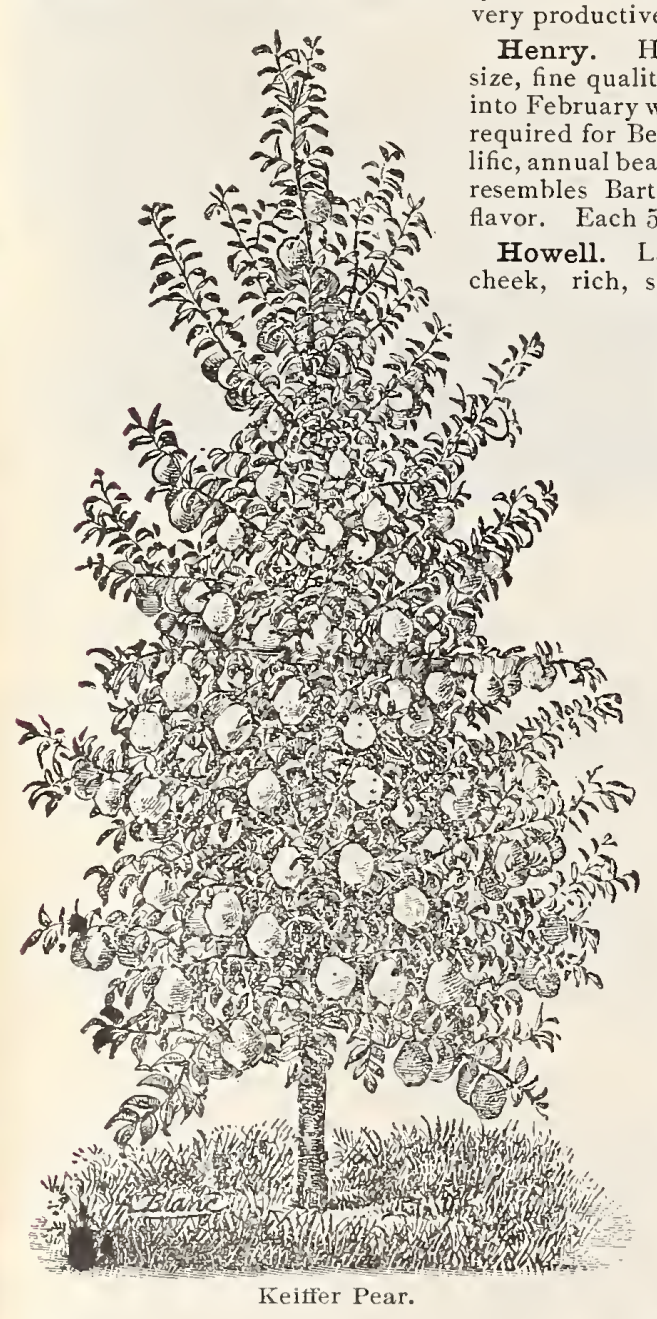

Productive. Each 50c, doz. \$o. size, fine quality, long keeper, lasting into February with no more care than required for Ben Davis Apple. Prolific, annual bearer ; color rich yellow ; Howell. Large, yellow, with red cheek, rich, sweet, melting, early bearer, productive, ripens in September and October. Each $50 \mathrm{c}$, doz. $\$ 4.50$.

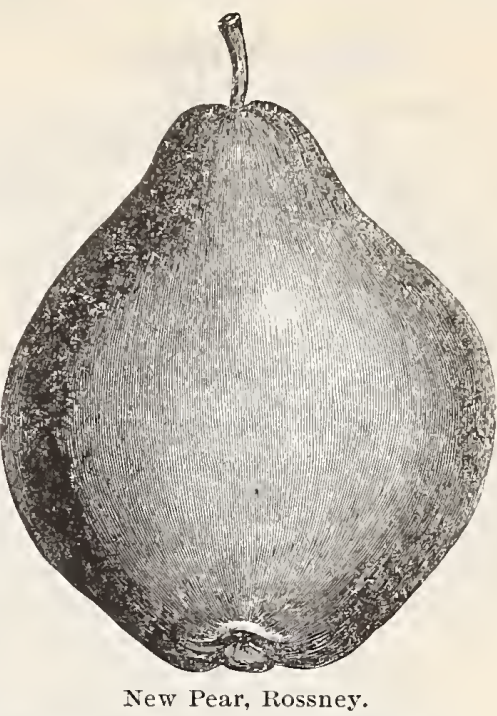

STANDARD, WELL KNOWN VARIETIES.

Prices uniform, as follows: 2-year-old trees, 5 to 7 feet, each $40 \mathrm{c}$, per dozen $\$ 3.50$.

Garber. Larger than Keiffer, beautiful yellow.

LeConte. Large, of fair quality, ripens in August, succeeds well in Mississippi.

Koonce. Of large size, and of good form and color.

Keiffer. Golden yellow, tinged with red on one side, flesh firm, juicy and of agreeable flavor, remarkably free from blight, ripens in September.

Bartlett. Fine yellow, faint blush, fine grained and juicy, ripens in August.

Duchesse D'Angouleme. Very large, greenish, melting and juicy, ripens in October.

Clapp's Favorite. A fine pear, fruit resembles Bartlett, ripens in August.

Lawrence. Medium to large, golden yellow, ripens in November.

Flemish Beauty. Large, melting, sweet, ripens in August.

Mt. Vernon. Light russet color on vellow ground, flesh yellow, juicy and aromatic, ripens in October.

Buffum. Deep yellow, tinged with red, flesh white, sweet and of excellent flavor, ripens in August.

Kingessing. Large, greenish yellow, flesh white, juicy, melting and sweet, ripens in August.

Early Harvest. Largest early market pear, golden yellow with crimson on sunny side, ripens in June or July.

Wilder's Early. Bright yellow, shaded with carSeckel. Small, yellowish brown, sweet, ripens in September.

Beurre d'Anjou. Large, juicy and melting, an ex-

Bloodgood. Russet yellow, flesh yellowish white, buttery, with rich flavor.

cellent pear and a good bearer.

\section{Cherries.}

Strong 2-year-old trees, each 40c, per. doz. \$3.50.

May Duke. Large, dark red, very juicy and melting, ripens in May.

Late Duke. Large, light red, late and excellent, ripens last of June.

Early Richmond. Fine, very early, most popular of all, ripens in May.

Wright's Mammoth. Vigorous grower, fruit large.
Gozernor Wood. Very large, rich, juicy and sweet, ripens last of May.

Black Tartarian. Large, black, juicy, rich, excellent, ripens last of June.

Olivet. Large, globular, a shiny, deep red sort, ripens middle of June.

Wright's Early. A native variety, ripens early. 


\section{Apples.}

Bismarck Apple. Tree of short and stocky growth; thick, healthy foliage; makes beautiful specimens grown in pots for decorative purposes. Fruit large, handsome, yellow, sometimes shaded red cheek; flesh tender, pleasant sub-acid. Entire ly new in its remarkable quality of producing crops on young trees, seldom failing to bear when two years old. Each $50 \mathrm{c}, \frac{1}{2}$ doz. $\$ 2.50$.

Standard 2-year-old trees, 5 to 7 feet, each $20 \mathrm{c}$, per doz. $\$ 2$, per $100 \$ 15$.

\section{SUMMER VARIETIES.}

Duchess of Oldenberg. Fine yellow, with stripes of brilliant red, ripens in July.

Early Colton. Yellowish white, tinted with carmine, ripens in June or July.

Early Harvest. Fine yellow, flesh very tender, with fine flavor, ripens in June.

Family. Yellowish, splashed with crimson, ripens in July.

Horse. Large to very large, yellow, fine for cooking. Ripens in August.

May Pippin. Roundish, regular, greenish yellow, ripens in May and June.

Red Astrachan. Greenish to yellow ground, nearly covered with crimson, ripens in June.

Red June. Dark crimson, fine grain, moderately juicy.

Summer Queen. Flesh yellow, firm, rich, fine flavored. ripens in July.

Yellow Transparent. Large, beautiful, clear yellow, flesh fine grained, juicy, rich.

Dr. Sherman. Red, slightiy striped, of good size, ripens in June.

Julian. Flesh yellow, juicy, fine high flavor.

Summer Pearmain. A fine summer variety of large size, light red striped on yellow ground, juicy and of fine flavor, ripens in July.

\section{FALL VARIETIES.}

Bachelor. Large, flesh yellow, tender, agreeable flavor, ripens in November.

Bell Flower. Oblong, fine rich yellow, juicy, acid and refreshing.

Fall Pippin. Large, yellow, ripens in September.

Fall Strawberry. Finely striped, juicy and excellent, ripens in September.

Gravenstein. Striped with red, crisp, juicy, ripens in September.

Maiden's Blush. Large, pale yellow, bright red cheek, ripens in September.

Gloria Mundi. One of the very largest apples, greenish yellow, ripens in September.

Yates' Mammoth. A new variety, originated here, fruit large, handsome, richly striped and splashed with bright crimson, ripens in November.

Hoover. Very large, yellow, splashed and striped with red, flesh firm and rich.

\section{WINTER VARIETIES.}

Ben Davis. Large greenish yellow, striped with red, flesh white.

Black Twig. Resembles the Wine Sap, except that it is from one-third to one-half larger.

Wine Sap. Rich, dark red, flesh fine creamy yellow, and very juicy.

Shockley. Waxen yellow, with crimson cheek, flesh yellow, very firm.

Arkansas Black. Large, dark crimson, flesh yellow, a fine keeper.

Grimes' Golden. Golden yellow, crisp, tender, juicy.

Hall. Light yellow, covered with bright red.

Kentucky Streak. Large, handsome, flesh white.

Kinnaird's Choice. Medium to large, flesh crisp, tender, high flavored, celebrated Tennessee winter apple.

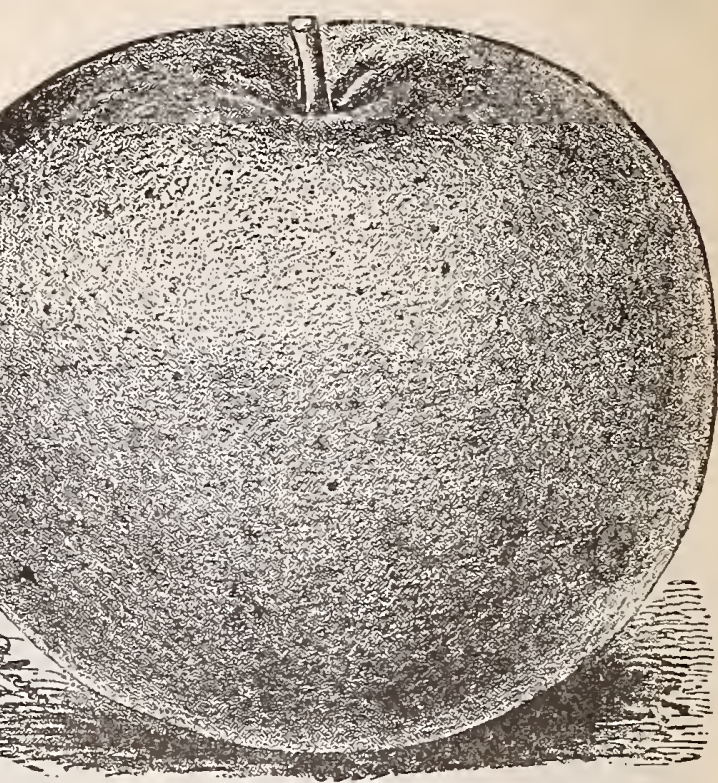

Yates' Mammoth Apple.

Tull. A fine winter apple, good keeper, tree hardy, fruit large, green, with red stripes, fine quality.

Nickajack. Large, roundish, yellowish, covered with dull red.

Janet. Yellow, light red stripes, crisp, very juicy, rich. Carter's Blue. Very large, green, crisp, sugary, rich.

Arkansas Beauty. Large, bright red, and deserving of its name Beauty, succeeds well in this section.

Shannon. Does well in Arkansas, one of the very finest large apples.

Golden Russet. Medium size, bright russet color, crisp and juicy.

Red Limber Twig. A famous winter variety, good size, greenish yellow, faint crimson stripes, keeps well.

Buckingham. Very large, rich yellow, covered with red, flesh white, tender and juicy, a splendid apple, ripens in October.

CRAB APPLES.

Each 25c, per doz. \$2.40.

Hyslop Crab. Large, grows in clusters, purplish red. Martha Crab. Large, creamy yellow, with light vermillion blush.

Whitney's No. 20 Crab. Large, striped, flesh firm and juicy.

Red Crab. Small, red, very profitable cider apple.

Transcendent. Large, yellow, fine flavor.

Yellow Siberian. Small, productive, fine for preserving.

Golden Beauty. Large, bright yellow, mild flavor.

Hewes' Virginia. Very prolific, one of the best.

Red Siberian. Bright red, a most beautiful variety.

\section{NEW APPLES.}

We have the following new apples in 1-year-old trees; price $20 \mathrm{c}$ each, doz. $\$ 2$ :

Benoni.

Carolina Greening.

Carolina Striped J

Early Pennock.

Early Red IN

Gano.

Hargrove.

Hayden's Favorite.

Hayden's Favorite. Terry.

Ingram.

Jonathan.
Kansas Queen.

Mangum.

Pine Stump.

Ragan's Yellow.

Romanite.

Summer Golden Pippin.

Simmons' Red. Stevenson's Winter.

Twenty Ounce.

Washington Strawberry. York Imperial. 


\section{Grapes.}

Two-year-old strong vines, each $20 \mathrm{c}$; per dozen $\$ 2$, (except where noted otherwise).

Perkins. Pinkish white, becoming nearly red when ripe.

Empire State. Vine hardy and vigorous, berry white, excellent flavor. Keeps well.

Pocklington. Bunch and berry large; color, golden yellow. Juicy, tender and sweet.

Moore's Diamond. White, with rich yellow tinge, juicy, has few seeds, ripens extremely early.

Early Ohio. The earliest black grape known, ripens ten days to two weeks before Moore's Early; bunches large, berry of good quality, a vigorous grower, very productive. Each 25c, per doz. $\$ 2.50$.

Delaware. Bunches small and compact, berries rather small, round, skin thin, light red; flesh very juicy, exceedingly sweet.

Lutie. Very early, large red berry, free from rot.

Brighton. Large, coppery red, sweet, best quality. June.

Concord. Large, black, juicy, sweet when fully ripe. July.

Worden. Of the Concord type, larger in bunch and berry.

Moore's Early. Very large, black, two weeks earlier than Concord, fine.

Niagara. Bunches and berries large, sweet, greenish white.

Scuppernong. Bunches seldom ever composed of more than eight or ten berries; berries round, of a bronze color when fully ripe. Vine is free from all disease and attacks of insects. It is wonderfully prolific. Each $35 \mathrm{c}$, per doz. $\$ 3$.

\section{Apricots.}

Strong, 2-year-old trees, each 40c; per doz. \$3.50.

Early Golden. Small, pale orange, juicy and sweet.

Russian. Of best quality, ripens early, very productive.

Moorepark. Large, a standard, well known sort, freestone, productive.

\section{Figs.}

Each 35c, per doz. \$3.

Brown Turkey. The most reliable for open field culture, medium size, very sweet, prolific and hardy.

Celestial. Very large, violet, good and productive.

\section{Quinces.}

Strong, 2-year-old trees, each $40 \mathrm{c}$; per doz. $\$ 3.50$.

Champion. Extremely hardy, of stout, upright growth. The fruit is large, very showy and handsome, tender and rich in flavor.

Orange. Large, round, golden yellow, very fine.

Rea's Mammoth. An improvement upon the Orange quince, of which it is a seedling, much larger.

Meeche's Prolific. Fruit large, immensely productive, and of a lively orange color.

\section{Nectarines.}

Strong, 2-year-old trees, each, 35c; per doz. \$3.

Hunt's Tawny. Small to medium, rich and juicy.

Stanwick. Deep yellow, very sweet.

\section{Japanese Persimmons.}

We have the best variety of this excellent fruit, which succeeds in this section. Each $50 \mathrm{c}$; per doz. $\$ 5$.

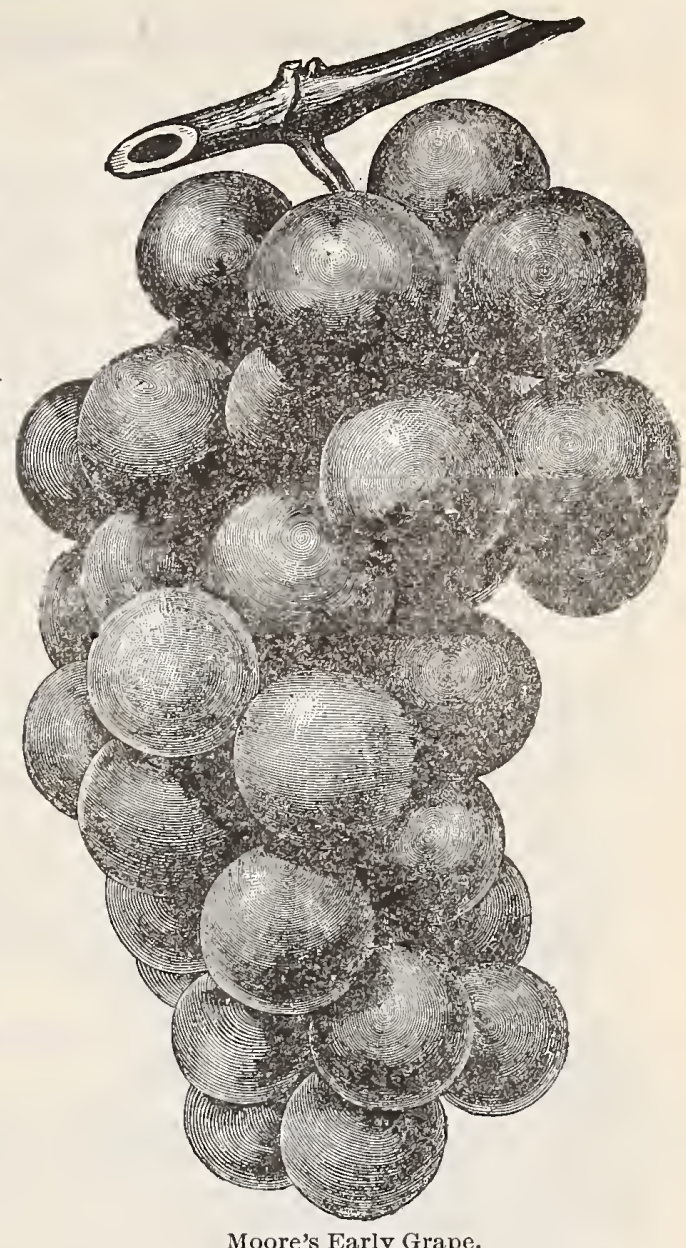

Moore's Early Grape.

\section{Nut Trees.}

\section{Each 50c; doz. \$5.}

Japan Walnuts. A native of the mountains of Japar. Extremely hardy and vigorous grower, of symmetrical and beautiful form. Three-year-old trees produce nuts. Wonderfully productive. Nuts produced in clusters. Shell thicker than that of the English walnut, but not as thick as that of the black walnut. Meat is sweet and of the best quality. The trees have an abundance of fibrous roots, transplant readily and you will not have to wait a lifetime for them to bear.

Almond-Soft Shell. Standard, popular, succeeds well here.

Chestnut-Spanish Sweet. Large, productive.

Filberts. Easy culture, dwarf, hardy, productive.

Pecan-Paper-Shell Louisiana. Large, nutmeg shape, thin shell.

Walnut-Black. Native variety, nice trees, 3 to 4 feet, the best size for transplanting.

Walnut-English. Most desirable, thin shelled.

Nursery Denartment Nothing is more healthful than fruits, and nothing more easily grown. Most of our customers can spare room for a small bed of strawberries, a few rows of raspberries, blackberries, or currants or grapes, and what is more delicious than a dish of fresh fruit from your own garden, instead of depending upon fruit which has stood in the hot sun all day in a market stall? It is wonderful the amount of fruit that can be grown in a space 30 or 40 feet square, and it costs but little for plants enough to fill it. And then you certainly have room enough for a few fruit trees. Our stock of all kinds has made a very fair growth the past season, and is in splendid condition, thoroughly acclimated, hardy, strong, well grown, properly labeled, and all will be pleased who order from us. Don't buy of tree peddlers, but send order to us and be sure of getting what you want. 


\section{Shade and Ornamental Trees.}

Good, strong well developed trees, each 75c; large specimens $\$ 1.00$ to $\$ 2.00$ each.

Carolina Poplar. Of very rapid growth, with large, deep green, glossy leaves; bears transplanting better than most other trees.

Lombardy Poplar. Kemarkable for its erect growth and pyramidal habit. Tulip Poplar. A rapid growing tree, with luxuriant, glossy foliage.

Silver-Leaved Maple. Tree of rapid growth, easily transplanted, is in great demand for planting on streets or in parks.

Sugar or Rock Maple. Very hardy, makes dense shade, pyramidal shape Scarlet Maple. Quick growing tree, with red flowers very early in spring. Cork Bark Maple. A free, upright, rapid grower, deep green foliage

Salisburia (Maiden Hair Tree). Rare, elegant; dense, fern-like foliage. Larch, European. Pyramidal shaped tree; foliage light green, soft and graceful; a handsome tree.

Mountain Ash, European. A fine hardy tree, head dense and regular.

Catalpa Speciosa. A most rapid grower, large heart-shaped leaves, very ornamental and useful.

Catalpa, Tea's Japan. Large, luxuriant foliage, has beautiful white flowers with a pleasant and delicate fragrance.

Elm, American. A noble native tree of large size, one of the grandest park and street trees.

American Linden. Rapid grower, with round head and luxuriant foliage.

Texas Umbrella China. Low, dense spreading growth, foliage deep green, admirable for the South.

Double Flowering Peach. White and red, Camelia-shaped flowers

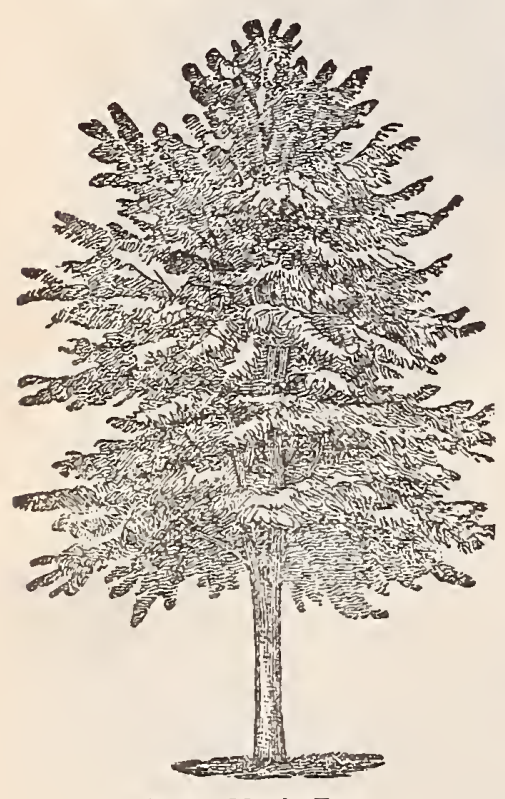

We can also supply the following well known varieties, prices as above:

$\begin{array}{lll}\text { Magnolia Acuminata. } & \text { Horse Chestnut. } & \text { Ky. Coffee Tree. } \\ \text { Magnolia Tripetala. } & \text { Sweet Gum. } & \text { White Dogwood. } \\ \text { White Birch. } & \text { American Beech. } & \text { Weeping Willow. }\end{array}$

European Beech.

\section{Evergreen Trees.}

12 to 15 inches, $50 \mathrm{c}$ each; 18 to 24 inches, $\$ 1$ each; 24 to 36 inches, $\$ 2$ each.

American Arbor Vitæ. Valuable for screens and hedges.

Irish Juniper. Very erect. compact and dense.

Magnolia Grandiflora. The grandest of all Southern evergreens, and there is no tree that excels the Magnolia in regal grandeur when its immense white blossoms are gleaming from among its large, lustrous green leaves.

We can also supply the following well known species, prices as above:

Balsam Fir. Norway Spruce. English Yew. Irish Yew. Tree Box. Lawson's Cypress. Golden Arbor Vitæ.

\section{Deciduous Ornamental Shrubs.}

\section{Each 50c.}

Calycanthus.

Common Lilac.

Snowball.

Deutzia Crenata. Pyrus Japonica. White Fringe. Althea.

Crape Myrtle.

Japan Quince. Spirea.

Hydrangea Paniculata Grandiflora.

California Privet. A most desirable hedge plant, can be pruned to any

Silver Maple Tree.

shape, succeeds anywhere. Each $150 \mathrm{c}, 100 \$ 10.00$, large specimens, 25c each.

\section{Climbing Plants.} Each 50c. Virginia Creeper, or American Ivy. $\begin{gathered}\text { English Ivy. } \\ \text { Chinese Honeysuckle. }\end{gathered}$ Blue Wistaria.
White Wistaria.

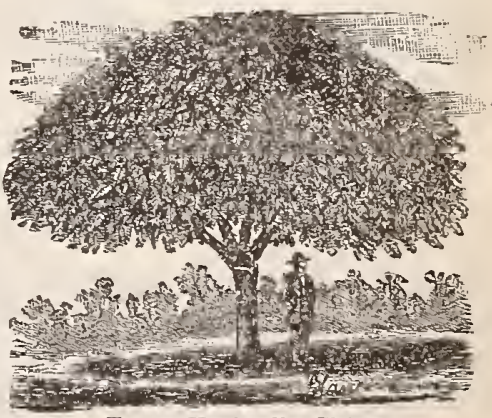

Texas Umbrella China.

is very simple. It far surpasses - Per package $\$ 1$, by express.

Don- Fail The Greatest Discovery of the Age for Hortlculturists! Prof, Null's Plant Tonic and Insect Destroyer, As the name implies, a specific insecticide. Kills all insects with which the tree is infected and acts as a general tonic, increasing both size and quality of the fruit, and will prevent the much dreaded blight that is so fatal to fruit culture. This Tonic is a sure preventive of Pear Blight; and if the trees are affected, one application will destroy the blight in a few days. It will also destroy and eradicate every borer in a few days, in old or young peach trees, and cause the tree to grow vigorously. It is good for all kinds of fruit, plums, apricots, apples, 


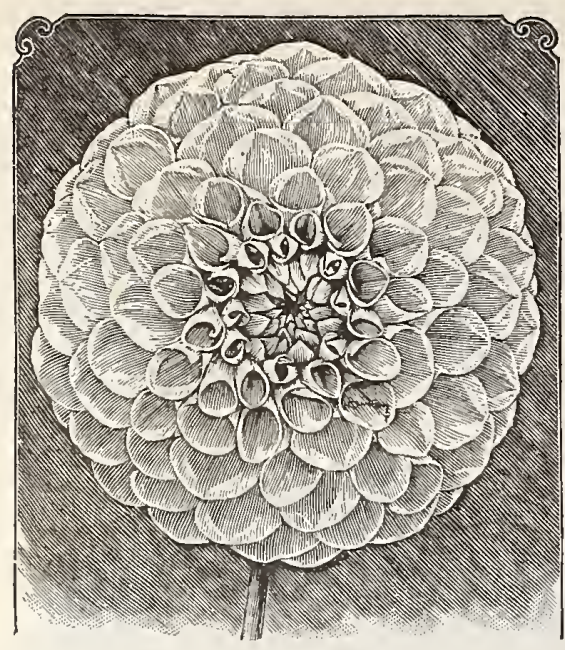

Dahlia, Grand Duke Alexis.

\section{SUMMER FLOWERING BULBS.}

\section{Dahlias.}

Storm King. Snow white, perfect form, full to the center, a profuse and constant bloomer.

Admiral Dewey. A valuable new variety, large flowers of beautiful, rich purple.

John Elitch. Flowers very large, five to six inches in diameter, color bright, dazzling red.

Floral Park Jewel. Flowers of many colors, from deep maroon to bluish white, also beautifully spotted and variegated forms, all on the sanie plant.

Grand Duke Alexis. Large, massive flowers, beautiful form, ivory white, petals tubular, sufficiently open to show a faint blush.

Henry Patrick. A superb, large, pure white variety of large size and borne on long stems.

Mrs. E. C. Monroe. A lovely shade of sulphur yellow, flowers large, of perfect form, beautifully reflexed.

Nymphae. Large, graceful, robust grower; a novel, clear delicate pink. A mass of blooms from July until frost.

Wm. Agnew. Flowers very large, always full to the center, long petals, outer row beautifully twisted, richest sliade of intense dazzling red.

Purity. Purest snow white, vigorous grower, free bloomer.

Miss May Lomas. One of the grandest in the entire list, exquisite white, faintly suffused with soft, rosy lavender.

Black Prince. Large, intense velvety maroon, almost black. Blooms in great profusion

Dahlias, each 25c, postage paid; by express, each $20 \mathrm{c}, 3$ for $50 \mathrm{c}$, doz. \$2. Mixed, all colors, each $15 \mathrm{c}$, per doz. $\$ 1.50$.

\section{Large Flowering Cannas.}

(Best Standard Sorts.)

Alphonse Bouvier. Large, brilliant scarlet, rich and velvety. Alsace. Very light, sulphur yellow changing to clear white. Austria. The golden lily-flowered canna, flowers immense. Burbank. Rich canary yellow, with carmine spots in the throat. Chicago. Very showy, brilliant orange scarlet. Free bloomer. Egandale. Foliage dark greenish maroon, flowers bright cherry. Florence Vaughn. Flowers large, bright yellow, spotted scarlet. Italia. The orchid-flowered canna. A grand yellow flower.

Mme. Crozy. Scarlet, with a golden edge. Very popular sort.

Philadelphia. Bright glowing crimson, rich and velvety, early.

President Cleveland. Immense trusses. Flowers orange scarlet and very large.

Queen Charlotte. Orange scarlet, broad golden yellow edge.

Any Variety. Each $15 \mathrm{c}$, per doz. $\$ 1.50$, postage paid; by express, each, $10 \mathrm{c}$, doz. $\$ 1$.

\section{Hardy Lilies.}

Lilium Auratum. The glorious gold banded lily of Japan, and one of the grandest plants in cultivation. Its immense ivory white flowers are thickly studded with yellow and crimson spots, while in the center of each petal is a golden band, fading at its edges into the white. Each $25 \mathrm{c}$, postage paid; by express, each 20c, doz. $\$ 2$.

Lily of the Valley. No garden is complete without a few clumps of these fragrant flowers. 40c, express only.

\section{Tuberoses.}

Double Dwarf Pearl. Flowers very double and large. Each $5 \mathrm{c}$, doz. 50c, postpaid; by express, doz. 35c, $100 \$ 2$.

Albino. Single, white, very early and fragrant. Prices same as double variety.

YUCCA (Adam's Needle). A tropical looking plant, with long, narrow leaves that remain green the entire year; has strong flower stem three or four feet high, bearing a large spike of creamy white, bell-shaped flowers; Fine for cemeteries, lawns, centers. Each 50c, by express.

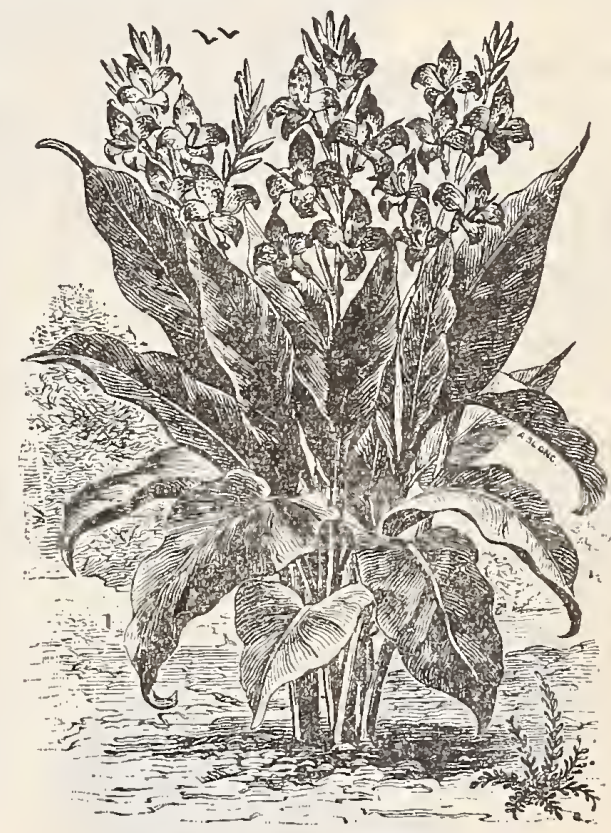

Canna, Queen Charlotte.

\section{Giladiolus.}

Qne of the most attractive of summer flowering bulbs; finest, select, mixed, all colors. Doz. $35 \mathrm{c}$, postage paid; by express, doz. $25 \mathrm{c}, 100 \$ 1.50$.

Gladiolus Childsii. Superb, large flowered, mixed colors. Doz 60c, postage paid; by express, doz. 50c.

Gladiolus, Groff's New Hybrid. A splendid new strain, of the largest size and greatest diversity of colors. Doz. $75 \mathrm{c}$, postage paid.

\section{Miscellaneous Bulbs.}

Caladium (Elephant Ears). By mail, each 25c; by express, each $15 \mathrm{c}$, doz. $\$ 1.50$.

Pæonias. Double white and double. crimson. By mail, each $30 \mathrm{c}$; by express, each 2 ic, doz. $\$ 2.50$.

Madeira Vine. A popular climber. By mail, doz. $60 \mathrm{c}$; by express, doz. 50c.

Cinnamon Vine. Quick growing vine. By mail, each $10 \mathrm{c}$; by express, doz. $75 \mathrm{c}$.

Oxalis. Summer flowering. Mixed, all shades. Doz. 25 c, $100 \$ 1.50$. 


\section{Greenhouse and Bedding Plants}

PLANTS FREE On all orders to the Pr amount of $\$ 5$ or over, will gives or bulbs, at catalogue prices, we your own selection. $\therefore \therefore \therefore \therefore \therefore \therefore \therefore$

PLANTS BY EXPRESS. All plants by express. We do not send them by mail. Remember we can always send you larger and better plants when sent by express. $\therefore$.

\section{Condensed List.}

For want of space, we give here only a condensed price list of plants. Do not fail to watch the prices, however; they should bring us your orders. A complete Floral Catalogue, published by the Idlewild Greenhouses, will be mailed to all customers on request. Same will be ready early in February, 1903.

Alyssum, Sweet-Single..

\begin{tabular}{rr}
\multicolumn{1}{c}{ Each } & Dozen \\
$\$ .10$ & $\$ .75$ \\
.10 & 1.00 \\
.10 & .75 \\
& \\
.10 & .75 \\
$.15-.25$ & $\ldots \ldots$. \\
$.15-.25$ & $\ldots \ldots$. \\
.15 & 1.50 \\
.35 & $\ldots \ldots$. \\
$.25-.50$ & $\ldots \ldots$. \\
$.50-.75$ & $\ldots \ldots$. \\
.15 & 1.50 \\
$.25-1.00$ & $\ldots . .$. \\
$.25-.50$ & $\ldots \ldots .$. \\
.15 & 1.50
\end{tabular}

Althernantheras-Three varieties..

(Per 100, \$3.00).

Ageratum-White and blue.

Asparagus Plumosus Nanus.....

Asparagus Sprengeri.

Begonias-All choice kinds...........

Caladium-Fancy leaved sorts.........

"، $\quad$ Elephant Ears.............

Cannas-Fine assortment.

Calla Lily-In pots.

Calla_Little Gem

Carnations-Twelve fine sorts........

15

1.50

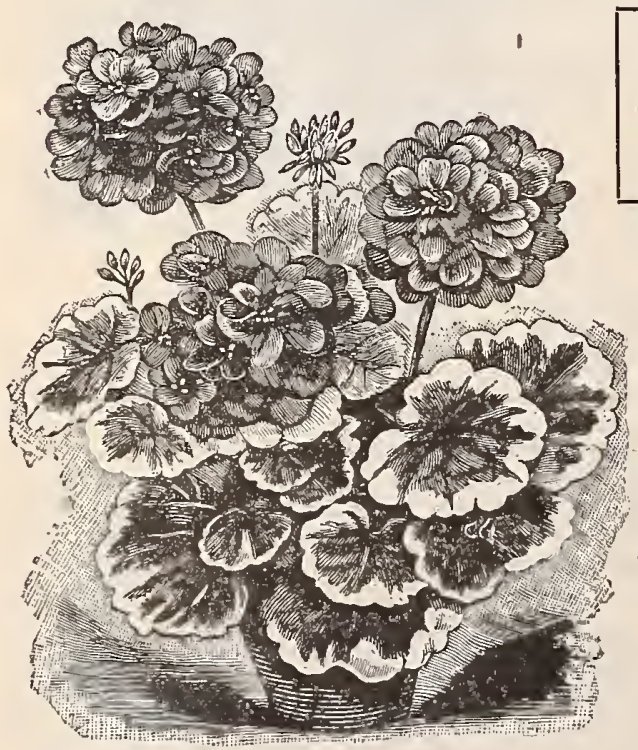

These prices cancel all previous price lists and catalogues

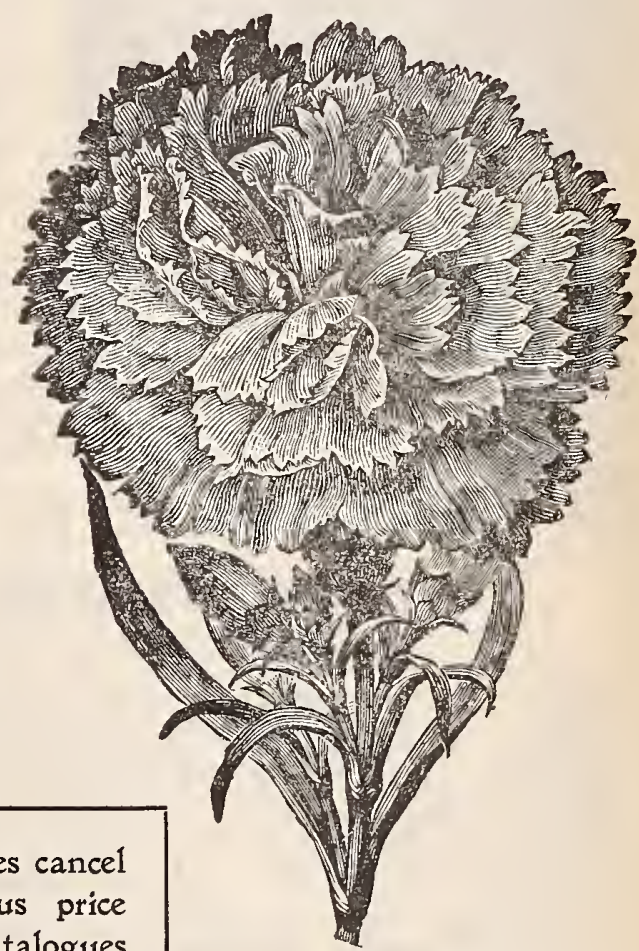

Carnation, Jubilee. Each 15c,
dozen $\$ 1.50$.

Centaurea-Dusty Miller

Each

Dozen

Chrysanthemum-All fine sorts....

$\$ .05$

Cuphea-Cigar Plant...................

.10

$\$ .50$

.10

1.00

Daisy.

1.00

Geraniums-All colors................

.75

.10

1.50

Fancy new varieties....

2.50

Heliotrope.

.25

.15

1.50

Hibiscus-Single and double.........

$.15-.25-.50$

Hollyhock.

.20

Hydrangea.

Jessamine-Night Blooming...........

$.15-.25-.50$

" Maid of Orleans .........

$.15-.25-.50$

$1.50-2.00$

" Grand Duke...............

$.15-.25-.50$

$1.50-2.00$

" Cape.

$.15-.25-.50$

$1.50-2.00$

Lantana-Three varieties.

.10

1.00

.15

1.50

We Fill Orders Promptly as soon as weather permits. Send in your orders early while your trade and will treat you right. A trial order will convince. Terms Cash with Order. 
GREENHOUSE AND BEDDING PLANTS-Continued.

Lemon Verbena...... $\$ 10 \$ 1.00$

Mignonette.................... $.10 \quad .75$

Nasturtium-dwarf or tall. $.0 . \overline{5} \quad .50$

Pansy-Finest stock......... $\quad .10 \quad 1.00$

Petunia_Single, all color... $.10 \quad 1.00$

Double............. .15 1.50

Plumbago................. .15-.25

Phlox-Annual, fine assort-

ment ............................. $10 \quad 1.00$

Phlox-Perennial............. .15 1.50

Salvia-Scarlet Sage.......... . .10 1.00

Smilax.......................... .15 1.50

Swainsonia....................15-.25

Verbena_Fine assortment. $\quad .10 \quad 1.00$

Violets-Single................. $\quad .10$

"6 Double............... $.15 \quad 1.50$

$\begin{array}{llll}\text { Vinca-White and pink ...... } & .10 & 1.00\end{array}$

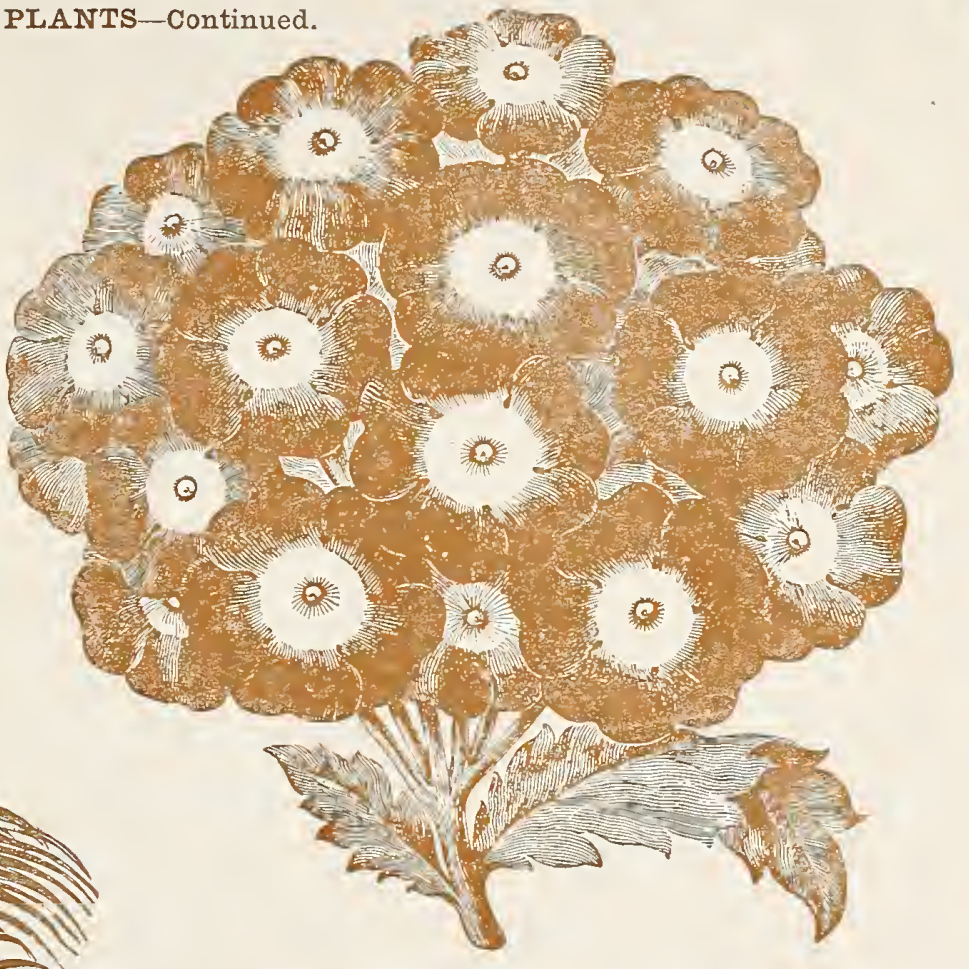

Verbena, Mammoth Flowering.

\section{Vines and Climbing Plants.}

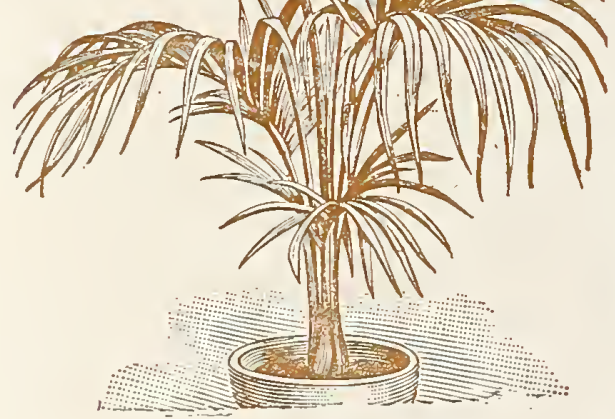

Each Doz.

Ampelopsis-Boston Ivy

$\$ .15 \$ 1.50$

Cobæa Scandens.

1.50

Clematis - White and purple..

.75

Ciscus Discolor

Hop Vine.

Tradescantia - Wandering Jew, three sorts............ $\quad .10$

Ivy-German, or Parlor ................................

\section{Palms, Ferns, Decorative Plants.}

All plants go by express at purchaser's expense.

Auracaria Excelsa

Areca Lutescens..

Cocos Weddeliana

Kentia Fosteriana.

Latania Borbonica

Pandanus Veitchii

Pandanus Utilis.

Phœnix Family.

\section{Sago}

Aspidistra-Elegant window plant.

Farfugium Grande-Leopard Plant

Rubber Plant.

Umbrella Plant-Cyperus alternifolius..

IIaiden Hair Fern

Boston Fern.

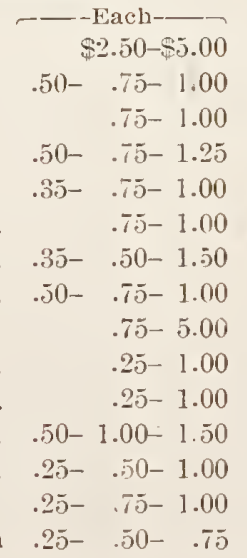

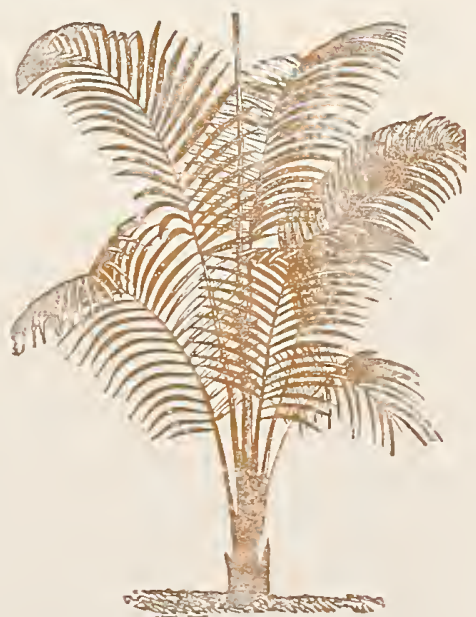

Palm, Areca Lutescens. 


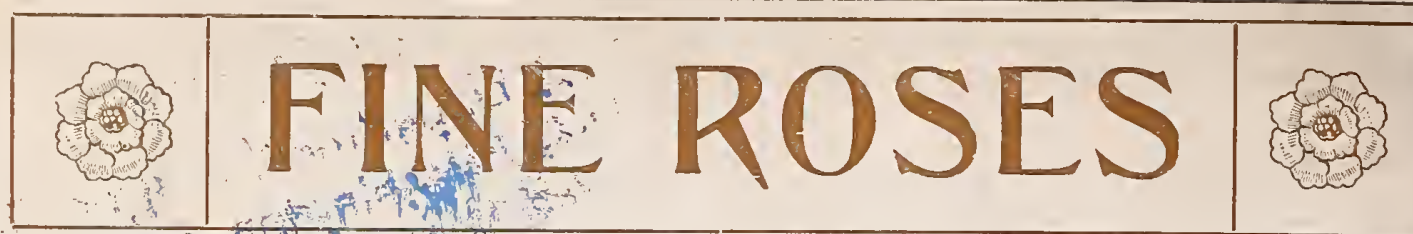

We have a fine stock of healthy, vigorous roses-heavy, field grown plants-that will bloom profusely this year, if planted early. We can ship these promptly on receipt of order. We send them by express only. These plants are too large for mailing. * * *

\section{3=YEAR=0LD FIELD GROWN PLANTS.}

RED.

American Beauty Archduke Charles Christine de Noue Duke of Edinburg Gen. Jacqueminot Meteor

Mme. Chas. Wood

\section{Each 50 cents, 12 for $\$ 5.00$.}

Papa Gontier

Princess de Sagan

Paul Neyron

Princess Bonnie

Prince Camille de Rohan

Souvenir de Wooton

Triumph de Pernet Pere

\section{YELLOW.}

Etoile de Iyon Mme. Caroline Kuster Perle des Jardins
Bridesmaid

Burbank

Catharine Mermet

Duchess de Brabant

Duchess of Albany Golden Gate

Bride

Kaiserine Aug. Victoria

Devoniensis

IMarie Guillot
PINK.

Hermosa

Ia France

Maman Cochet

Maid of Honor

Mrs. De Graw

Caroline Testout

WHITE.

Marie van Houtte Mme. Jos. Schwartz Marie Lambert White La France
RED.

Clb. Meteor

Clb. Wootton

Empress of China
Helene

Reine Marie Henriette

Crimson Rambler

PINK.
Baltimore Belle Clb: Bridesm'd Pink Rambler

\section{CLIMBERS.}

WHITE.

Clb. Marie Guillot Mary Washington Mrs. Rbt. Pearry White Rambler YELLOW.

Cloth of Gold Yellow Rambler Solfaterre W. A. Richardson

\section{2=YEAR=OLD FIELD GROWN PLANTS.}

American Beauty Archduke Charles Bride

Bridesmaid

Bon Silene

Catherine IMermet

Countess I. Kinsky

Clothilde Sounert

Christine de Noue

Clio

Cornelia Cook

David Praddle

Devoniensis

Duke of Edinburg

Baltimore Belle

Clb. Meteor

Clb. Wootton

Clb. Bridesmaid Aug. Guinnoisseau

\section{Each 35 cents, 6 for $\$ 1.75,12$ for $\$ 3.00$.}

Duchess de Brabant

Duchess ô Albany

Etoile de Lyon

Enchantress

Franciska Kruger

Gen. Jacqueminot

Gen. Robert E. Lee

Golden Gate

Hermosa

Kaiserin Aug. Victoria

La Pactole

La France

Meteor

Media

IMosella

2-YEAR-OLD

Clb. Marie Guillot

Clb. Kais. A. Victoria

Cloth of Gold

Empress of China
Marie Guillot

IMarie Lambert

Maman Cochet

IMaid of Honor

IMme. Chas. Wood

Marion Dingee

Mrs. Robt. Garrett

IMme. Carol Testout

IMme. Welch

IIme. Pernet-Ducher

IMme. Margottin

Mme. Caroline Kuster Striped La France

Marie van Foutte

Malmaison

Mme. Jos. Schwartz
Mrs. De Graw

Papa Gontier

Princess de Sagan

Perle des Jardins

Paul Neyron

Pink Soupert

Princess Bonnie

Prince Camille de Rohan

Red Hermosa

Sombreuil

Sunset

Queen

Triumph de Pernet Pere

Vick's Caprice

\section{CLIMBERS.}

Helene

Mary Washington

Reine IMarie Henriette

Solfaterre
Tennessee Belle

W. A. Richardson

Wichurianna

\section{Marechal Neil \\ Family, yellow, \\ white and red, $35,50,75 \mathrm{c}, \$ 1$ ea.}

Lemon Ponderosa. Something new, beautiful plant and fruit. $75 \mathrm{c}, \$ 1, \$ 150$ each. 